\begin{abstract}
UNIVERSIDADE DE SÃO PAULO
FACULDADE DE FILOSOFIA, LETRAS E CIÊNCIAS HUMANAS

DEPARTAMENTO DE LETRAS MODERNAS

PROGRAMA DE PÓS-GRADUAÇÃO EM LÍNGUA ESPANHOLA E LITERATURAS ESPANHOLA E HISPANO-AMERICANA

MARIANA SIERRA APONTE

Los giros del caleidoscopio: dos versiones lezamianas de la escritura sobre artes plásticas
\end{abstract}

São Paulo

2014 
UNIVERSIDADE DE SÃO PAULO

FACULDADE DE FILOSOFIA, LETRAS E CIÊNCIAS HUMANAS

DEPARTAMENTO DE LETRAS MODERNAS

PROGRAMA DE PÓS-GRADUAÇÃO EM LÍNGUA ESPANHOLA E LITERATURAS

ESPANHOLA E HISPANO-AMERICANA

\title{
Los giros del caleidoscopio: dos versiones lezamianas de la escritura sobre artes plásticas
}

\author{
Mariana Sierra Aponte \\ marianasierra@usp.br
}

mariana.sierra@gmail.com

Disertación presentada al Programa de Posgrado en Lengua Española y Literaturas Española e Hispanoamericana del Departamento de Letras Modernas de la Facultad de Filosofía, Letras y Ciencias Humanas de la Universidad de San Pablo, para la obtención del título de Magíster en Letras

Área de concentración: Literatura Hispanoamericana Orientadora: Profa. Dra. Adriana Kanzepolsky

São Paulo

2014 


\section{AGRADECIMIENTOS}

A mi orientadora, Prof. Dra. Adriana Kanzepolsky, por la oportunidad de elaborar esta investigación y por todas las orientaciones e indicaciones a lo largo de todo este proceso.

A los profesores Julio Ramos, Jorge Romero, Pablo Gasparini por la contribución a esta etapa de mi formación a través de las disciplinas que cursé con ellos. Sus opiniones y consejos fueron importantes para el desarrollo de este trabajo.

A los profesores Jorge Schwartz e Idalia Morejón, quienes participaron en mi banca de "cualificación" y me "dieron luces" a la hora de estructurar y reflexionar sobre esta disertación.

A mi padre y a mis hermanos por su apoyo incondicional desde Colombia y Estados Unidos. Sin ellos no hubiera podido concluir esta disertación.

A mis amigos, Rocío Pulgarín, Sandra Gazzoni, Afonso Lacerda, Jáder Muniz de Souza y Thais Tchobnian por su amistad, cariño y comprensión.

A Felipe Restrepo David porque juntos construimos un hogar y una convivencia agradable y amena donde dialogamos y compartimos muchos momentos.

A los amigos que dejé en mi país, en especial a Ana María Avellaneda por su presencia y nuestros diálogos y risas inacabables.

A todos aquellos que conocí en San Pablo y en Campina Grande (Paraíba) porque sin sus aportes no hubiera llegado hasta aquí. 


\section{RESUMEN}

La crítica de arte escrita por el poeta, narrador y ensayista José Lezama Lima proporciona una triple perspectiva. Observa -tanto en los ensayos compilados en La visualidad infinita, como en los artículos de la revista Orígenes- el diálogo entre las corrientes artísticas internacionales y una pintura vanguardista cubana, reflexiona sobre elementos propios de la labor plástica y teje un continuo contrapunto entre la poesía y la pintura. Este encuentro entre los dos quehaceres artísticos, donde la imagen juega un rol fundamental, desdoblándose en el par imago visible-pictórica e imago invisible-poética, es el eje desde el cual pueden pensarse los planteamientos críticos de este autor sobre ambas manifestaciones estéticas, el pintor René Portocarrero y los procedimientos y técnicas de la composición pictórica. Si la crítica de arte hace parte de una poética lezamiana, un análisis acerca del modo de esta continuidad se constituye en el centro del presente proyecto de investigación. Nuestro propósito es analizar la percepción de la historia en estas dos artes, la prolongación entre los elementos del sistema poético y las propuestas acerca de la pintura en los dos ensayos extensos "Paralelos. La pintura y la poesía en Cuba en los siglos XVIII y XIX" y "Homenaje a René Portocarrero". Como se trata de un estudio que parte de la literatura hacia las artes visuales, nos interesa el modo (o las operaciones) en los que desde el discurso de este escritor se asume el texto pictórico, la obra plástica. De esta manera, incursionamos en los planteos de disciplinas como la ecfrasis o en el desarrollo histórico de la frase horaciana "Ut pictura poesis", una reflexión que evidencia la antigüedad del lazo entre ambas disciplinas estéticas e, igualmente, demuestra su actualidad, ya que en las dos últimas décadas asistimos a la multiplicación de estudios dedicados a este vínculo tanto en el ámbito anglosajón como en algunos sectores de la crítica literaria en lengua española.

Palabras clave: crítica de arte, ensayo, ecfrasis, ut pictura poesis, poéticas visuales en José Lezama Lima. 


\begin{abstract}
The writings about art criticism from the poet, narrator an essayist José Lezama Lima provides a triple perspective. Observes -in the essays collected in La visualidad infinita as well as in the articles of the journal Orígenes- the dialogue between the international artistic movements and an avant-garde Cuban painting, reflects on elements pertaining to plastic works and weaves a continuous counterpoint between poetry and painting. This encounter of the two artistic endeavors, where image plays a fundamental role, unfolding in the pair imago visible-pictorial and imago invisible-poetic, is the axis from which one can understand the Lezama's critical proposals about the history of both aesthetic manifestations, the painter René Portocarrero and the methods and techniques of the pictorial composition. If art criticism is part of a lezamian poetic, an analysis regarding the character of this continuity constitutes the center of this research. Our objective is to analyze the historic perception in these two arts, the continuation between the elements of the poetic system and the approaches about painting in the two extensive essays "Paralelos. La pintura y la poesía en Cuba en los siglos XVIII y XIX" and "Homenaje a René Portocarrero". As it pertains to a study that begins in literature and moves to visual arts, we have interest in the mode (or procedures) in which from this writer's discourse, the pictorial text, plastic work is assumed. In this way, we make an incursion into the disciplines posed, like ekphrasis or in the historic development of the horatian sentence "Ut pictura poesis", a reflection that demonstrates equally the antiquity of the tie between both disciplines as well as its topicality, since in the past two decades we have seen the proliferation of studies dedicated to this bond not only in the English speaking world, but also in some areas of the literary criticism in Spanish language.
\end{abstract}

Keywords: art criticism, essay, ekphrasis, ut pictura poesis, visual poetics of José Lezama Lima. 


\section{ÍNDICE}

\section{INTRODUCCIÓN}

CAPÍtulo I - "PARALELOS. LA POESÍA Y LA PINTURA EN CUBA EN LOS SIGLOS XVIII Y XIX”: CAMINOS HISTÓRICOS Y DIÁLOGOS ENTRE LAS ARTES

1.1 HACIA LA CRÍTICA DE ARTE: SITUACIONES Y PARADOJAS 14

1.1.1 Baudelaire, Lezama y Casal: las mediaciones 20

1.1.2 Los otros espectros de una crítica poética de arte:

René Wellek y Northrop Frye 25

1.2 "PARALELOS...”: CONTRAPUNTO, ECFRASIS Y POIESIS UNIVERSAL 29

1.2.1 Los tropos de la historia 34

1.2.2 Metáfora 36

$\begin{array}{lll}\text { 1.2.3 Carencia } & 40\end{array}$

1.2.4 La expresión americana y Las eras imaginarias: la ficción de la historia $\quad 42$

1.3 UNA ERA IMAGINARIA Y DOS ESTÉTICAS 45

1.3.1 La estética de las resonancias $\quad 47$

1.4 "PARALELOS...": UNA RELACIÓN DE INTERPRETACIÓN ENTRE LA LITERATURA Y LA PINTURA $\quad 50$

1.4.1 “Paralelos...": poetas, pintores, encuentros y desencuentros 52

$\begin{array}{lll}1.4 .2 & \text { El paisaje, Martí } & 58\end{array}$

1.5 ECFRASIS (EKPHRASIS) Y UT PICTURA POESIS 61

1.5.1 La pintura para Lezama: aproximaciones a la relación poesía-pintura desde el Laokoon revisitado

Capítulo II - CRÍTICA DE ARTE Y CRÍTICA POÉTICA: UNA MIRADA AL ENSAYO "HOMENAJE A RENÉ PORTOCARRERO" 68

2.1 ENSAYO Y CRÍTICA: EL NACIMIENTO EN EL ERROR 68

2.2 LOS DIÁLOGOS Y LOS LÍMITES: LA HISTORIA Y LA CRÍTICA DE ARTE 70

2.3 OTRA VUELTA DE TUERCA A LA ESCRITURA CRÍTICA LEZAMIANA SOBRE ARTE

2.4 LA DIATRIBA ENTRE LO ALTO Y LO BAJO: EL ARTE DE ORIGEN BURGUÉS Y LAS MASAS 
2.5 UN ANÁLISIS EN FILIGRANA DEL ENSAYO "HOMENAJE A RENÉ PORTOCARRERO”

2.5.1 La tradición: una historia artística en clave cubana 82

2.5.2 Un sistema poético en una crítica de arte 85

2.5.2.1 La dialéctica de la imago $\quad 85$

2.5.2.2 La imagen y la ficción $\quad 87$

2.5.2.3 ¿Un diálogo torcido? Reflexiones acerca de la imagen en José Lezama Lima y

Pierre Francastel y del aura en Walter Benjamin y Georges Didi-Huberman 90

2.6 LEZAMA, BAUDELAIRE Y DELACROIX 100

2.7 ENTRE LA CARNE Y EL ESPÍRITU: LAS DIMENSIONES DE LA IMAGEN 107

2.8 LOS TIPOS DE ECFRASIS EN "HOMENAJE...” 109

2.9 LA ESCISIÓN EN LA VISIÓN: LA COPIA, LA CRÍTICA Y EL ARTE $\begin{array}{ll}\text { CONTEMPORÁNEO } & 115\end{array}$

2.10 ALGUNOS PASOS HACIA LAS CATEGORÍAS ESTÉTICAS 118

2.10.1 Aproximaciones al primitivismo, la visión táctil y las opciones de la pintura contemporánea

2.10.2 Los otros principios: Van Gogh y Ucello; Klee y Kandinsky 125

$\begin{array}{lll}2.11 & 129\end{array}$

$\begin{array}{ll}\text { CONCLUSIONES } & 133\end{array}$

$\begin{array}{ll}\text { ANEXOS } & 136\end{array}$

$\begin{array}{ll}\text { BIBLIOGRAFÍA } & 151\end{array}$ 


\section{INTRODUCCIÓN}

Al escritor sólo se le puede pedir cuenta de la fidelidad o no a una imagen: de ello depende no sólo su destino sino también su ética.

José Lezama Lima

No es necesario referirse a la extrañeza que produce la lectura de los textos lezamianos. Tampoco es necesario volver al lugar común que representa su obra en el imaginario de los lectores y críticos con adjetivos como "difícil", "oscuro" y "hermético", pese a que esta misma dificultad resulte en un estímulo, como rezan sus palabras de apertura a La expresión americana: "Sólo lo difícil es estimulante". De cualquier manera, es esta misma complejidad la que nos brinda motivos para investigar todavía acerca de la forma como este poeta, ensayista y narrador se aproximó a la crítica de arte. Gracias a las ambigüedades, a la dificultad que exhibe una escritura que oscila entre la imagen poética y el concepto, entre la autonomía del género y la especificidad de los escritos sobre las manifestaciones plásticas, podemos analizar el alcance de dos de sus textos: "Paralelos. La poesía y la pintura en Cuba en los siglos XVIII y XIX” y "Homenaje a René Portocarrero". Dos ensayos de temáticas diferentes cuyo desafío más importante fue el de no dejarnos absorber por la escritura del cubano, un reto proveniente de la contundencia de sus términos y del modo como opera su sistema conceptual.

Nuestro objetivo es, en realidad, tan solo un esbozo. Cada uno de los ensayos constituye por sí solo una disertación o una tesis dada la amplitud de los temas y la apertura a nuevos universos culturales. Quien lee a Lezama y se inquieta frente a sus textos explora otras disciplinas, inquiere sobre otras propuestas teóricas y artísticas. Cada una de las flechas lanzadas por el cubano deja una estela que no es rectilínea, por el contrario, es sinuosa, curva, de vaivén o de espiral. Esa es la forma del conocer lezamiano: nunca discurre linealmente, no se funda en la matriz causa-consecuencia o en el raciocinio lógico. De ahí que abordarlo obligue a un recorte, a la observación de una porción de esa estela mediante una selección de lo que a nuestro juicio pueden ser los temas centrales de acuerdo a la especificidad de cada ensayo.

Las diferencias entre ambos ensayos son notorias y nos llevaron a privilegiar zonas diversas. El primer texto, eje del primer capítulo, fue una conferencia leída en 1966 en el Museo Nacional y que posteriormente recibe el título de "Paralelos" delante del título 
original $^{1}$. Su carácter es básicamente histórico-descriptivo y comprende el concepto de las eras imaginarias junto con personajes históricos e inventados. Este lazo entre la historia y la imagen $\mathrm{o}$, en otras palabras, la capacidad de algunas culturas para crear símbolos imperecederos, como el mundo tanático de los egipcios o el taoísmo de los chinos, y la creación de figuras como el romano Rutilio Graco son dos de sus particularidades más sobresalientes. No obstante, de este texto nos interesa la forma como se estructura el diálogo entre ambas artes, la dimensión ficcional de la historia propuesta por nuestro autor, la importancia de Baudelaire en la configuración de un concepto de crítica donde prima el elemento subjetivo y las nociones de ecfrasis y ut pictura poesis.

En contraste, el segundo texto, "Homenaje a René Portocarrero", escrito en 1964, nos permite un análisis centrado en el modo como el escritor estructura su visión de la crítica de arte. Desde este punto de vista, elegimos la noción de imagen de Lezama y de críticos de arte como Pierre Francastel y Georges Didi-Huberman, e incluimos al filósofo Walter Benjamin y su teoría sobre el aura. La relación entre la imagen y el aura en la obra de arte nos autoriza a establecer una hipótesis sobre el juicio estético del poeta, sobre su noción de valor en la pieza estética. Así, las obras que elige pertenecen de preferencia a los pintores de la segunda vanguardia cubana y ejemplifican el valor de la obra aurática, del objeto que tiene el poder de devolvernos nuestra mirada, de llevarnos a un cuestionamiento. No obstante, existe un riesgo en el privilegio de estos principios teóricos y es que dejamos de lado un análisis minucioso de cada uno de los elementos mencionados en el texto dedicado a Portocarrero. Un sacrificio que también nos permitió proyectar una posible caracterización de esa escritura crítica.

Otros conceptos que aparecen son la ecfrasis y la frase horaciana Ut pictura poesis. Estas dos nociones provenientes de la teoría de los estudios interartes conforman el eje que nos posibilita explicar la presencia de poéticas visuales en la obra lezamiana. Con poéticas visuales entendemos las dos maneras con las que el autor configura las manifestaciones pictóricas a lo largo de su obra y no solamente en sus ensayos de crítica de arte. Una de ellas, la ecfrasis, es la manera en que un objeto plástico es vertido al discurso lingüístico; la otra, el carácter óptico de las obras lezamianas, es la presencia de metáforas visuales en su obra y no únicamente en su poesía o en sus ensayos de crítica de arte. Así, con la primera podemos explicar las estrategias de recreación de las obras plásticas a las que se refiere Lezama en su

\footnotetext{
${ }^{1}$ Su denominación era "La pintura y la poesía en Cuba". Posteriormente apareció en la revista Casa de las Américas 7 (41), p. 46-65, marzo-abril de 1967, con la adición "Paralelos", añadido que se mantiene en el volumen de ensayos La cantidad hechizada de 1970.
} 
crítica; con la segunda, vemos el anhelo de omnipresencia visual existente en su obra. Tanto en sus novelas, como en su poesía y en sus textos ensayísticos, asistimos a una puesta en escena de elementos ópticos mediante la descripción con colores y texturas o mediante la metáfora. Es en este punto que volvemos a la otra figura central de la disertación: Charles Baudelaire. Presente de maneras distintas en ambos capítulos, el poeta francés es el modelo del poeta-pintor, del escritor que busca crear en la poesía los efectos de la pintura. Un paradigma poético y crítico que explica la potencia de la visualidad en la totalidad de la obra literaria de nuestro autor y que también nos permitirá dilucidar sus ideales críticos en la obra de arte.

Por último, nuestras aproximaciones a una historia y a una crítica de arte lezamianas, explícitas en el primero y en el segundo capítulo, respectivamente, evidenciaron, una vez más, nuestra sospecha acerca de la unidad de su obra. Una uniformidad en la que no hay rupturas o quiebres en el pensamiento del autor y que nos permitió seguir sus planteamientos sobre el sistema poético en sus textos sobre crítica de arte. En este sentido, debemos entender la sentencia consignada en el epígrafe de esta presentación como el corolario de la fidelidad a sus ideas, de la coherencia en la totalidad de sus reflexiones. De este modo, aspiramos a una proximidad con la cohesión de su perspectiva desde las confluencias: la creación verbal y la visual, el proceso metafórico y el creativo, la poesía y la pintura. 


\section{CAPÍtUlO I - "PARALELOS. LA POESÍA Y LA PINTURA EN CUBA EN LOS SIGLOS XVIII Y XIX": CAMINOS HISTÓRICOS Y DIÁLOGOS ENTRE LAS ARTES}

(La) risita cejijunta, violenta pero ahogada, que tiene la misma virulencia, la misma energía de choteo y de impugnación que la carcajada, pero que nunca llega al estallido, a la explosión, al grafismo caricatural y sincopado.

Severo Sarduy. "Un heredero"

José Lezama Lima parece ser un caso extraño dentro de la tradición ensayística hispanoamericana. Ensayos como La expresión americana, Las eras imaginarias o aquellos donde se desarrollan sus planteamientos sobre un "sistema poético del mundo" han recibido y todavía reciben atención por parte de estudiosos y críticos, aunque no estén en algunas de las antologías dedicadas al género exclusivamente. Este es el caso de autores como Jhon Skirius (El ensayo hispanoamericano del siglo XX), Carlos Ripoll, (Conciencia intelectual de América. Antología del ensayo hispanoamericano (1836-1959), Ernesto Mejía Sánchez (El ensayo actual latinoamericano) o de la reciente compilación de Juan Escalera Ortiz (Antología del ensayo español, hispanoamericano y puertorriqueño). Una situación diciente de la no inclusión del cubano en una categoría donde aparecen Jorge Mañach, José Martí o Alejo Carpentier como autores de textos ensayísticos, cuyos temas no se circunscriben exclusivamente a la literatura sino también a la política e inclusive a la música ${ }^{2}$. Diferente es el caso de José Miguel Oviedo, quien en su Breve historia del ensayo hispanoamericano señala al poeta cubano como parte del eje del "pensamiento creador" junto con Borges y Cortázar, y lo caracteriza como un ensayista cuya estética barroca hace de la imagen poética el centro de su reflexión mediante un arte fundamentalmente digresivo (OVIEDO, 1991, p. 102-107). La notable erudición de Lezama es uno de los rasgos insoslayables para la crítica; una característica que evita la linealidad, la profundidad en un tema e invita a la apertura a la multiplicidad, a una escritura cuya imagen sería una espiral inacabable donde impera no el ritmo de la prosa y sí el de la poesía. Sin embargo, la dificultad de la lectura lezamiana, la preeminencia de un discurso donde el orden lógico es alterado a favor del orden sorprendente

\footnotetext{
${ }^{2}$ No es que José Lezama Lima no sea mencionado en textos como The Borzoi Anthology (editada por Emir Rodríguez Monegal) o la Historia y crítica de la literatura hispanoamericana (coordinada por Cedomil Goic), por solamente citar dos ejemplos sino lo que observamos es que el autor cubano no aparece en las antologías dedicadas al ensayo, como sí lo hacen otros autores -Octavio Paz y Alfonso Reyes - que, como él, trabajaron temas que excedían los asuntos literarios e incluían la valoración de las expresiones plásticas.
} 
de la palabra poética y la presencia de un lenguaje desbordante de citas "falsas" provenientes de autores de diversas tradiciones, convirtió al autor de Paradiso en el blanco de motes y prejuicios que tendían a ridiculizarlo. Apodos como "boticario de provincia", "negrito catedrático" o el "Buda de Trocadero" hacen parte de una tentativa de desdibujar su imagen como intelectual (PALMER, 2006, p. 21); situación que se vio justificada con la gran cantidad de erratas que aparecieron en las primeras ediciones de Paradiso y que también reflejan un problema editorial. Aunque estas incorrecciones escriturarias y el uso de citas "falsas" sean señalados, sobre todo, en el caso de la narrativa, desconcierta que sus ensayos más sobresalientes y objeto de estudio por parte de numerosos académicos no aparezcan en ninguna de las antologías del género antes mencionadas. Sin afirmar que este olvido tiene algún vínculo con la labor de algunos por restarle méritos, quizás se trate, más bien, de la falta de comprensión de ciertos planteamientos de un escritor cuya impronta ha sido notoria para Severo Sarduy, entre otros. En este sentido, la caracterización de Margarita Mateo Palmer en su texto sobre la relación de la escritura lezamiana con el choteo ${ }^{3}$ proporciona claridad sobre la forma de asunción del otro con sus citas "falsas" y el estilo particular del poeta.

Esta tendencia a la apropiación de los ajeno mediante la burla y la ironía puede relacionarse también con el choteo, no en su sentido peyorativo, sino en su violación jocunda de toda autoridad, su recusamiento de lo establecido, su burla a las jerarquías, su carácter transgresor de lo normativo. El sutil sentido del humor, la frecuente utilización de apodos para nombrar a los personajes, la hiperbolización de algunos rasgos defectuosos, la acotación irónica o burlona, realizada tangencialmente, de manera oblicua, de modo que su descodificación presuponga la participación de un juego de ingenio, son algunos de los rasgos de la prosa lezamiana que la vinculan al choteo (PALMER, 2006, p. 25).

El lazo con el choteo, con el "juego de ingenio", presupone un lector que, siguiendo las palabras de Cortázar en su "Carta a Lezama Lima", "merezca" al cubano en el sentido de ser

\footnotetext{
${ }^{3}$ El vínculo con el choteo también lo enuncia Severo Sarduy cuando brevemente, en Escrito sobre un cuerpo, menciona que en la superposición cubana presente en Paradiso "(...) se desliza, por el impacto mismo del collage, un elemento de risa, de burla discreta, algo de "choteo"" (SARDUY, 1969, p. 69). Aunque el contexto de esta nota sea diferente, ya que Sarduy alude a que Lezama lee lo cubano como superposición de culturas (la española, la africana y la china) y no como síntesis, refuerza nuestro punto de vista sobre el juego y la risa en la escritura lezamiana. No obstante, el verdadero punto de referencia es la "Indagación del choteo" de Jorge Mañach, donde se dice que "es un prurito de independencia que se exterioriza en una burla de toda forma no imperativa de autoridad" (MAÑACH, p. 108), vinculado con la anulación del respeto y la búsqueda de intimidad. (Indagación del choteo. Calibán. Revista Cubana de Pensamiento e Historia. Disponible en: http://www.revistacaliban.cu/articulos/9_indagacion_choteo.pdf?numero=9. Consultada en: 10 ago. 2012).Un rasgo que no es exclusivamente cubano y que también podemos ver a través del trabajo de Bajtin sobre la parodia y el carnaval en François Rabelais y la cultura popular en el Medioevo y en el Renacimiento (1965).
} 
capaz de "bajar a aguas profundas" (CORTÁZAR, 1996, p. 719), de emprender una tarea de decodificación que no es sencilla y que emula aquella frase citada innumerables veces y que da inicio a La expresión americana: "sólo lo difícil es estimulante". Este descenso o rechazo a permanecer en la superficie requiere un lector activo que quiera adentrarse en la dimensión de la extrañeza, en el juego de su escritura. Un aspecto lúdico que tal vez ha pasado desapercibido y que no es exclusivo de su narrativa. Sus ensayos también muestran esa situación organizada alrededor de la imagen poética. De ahí que su expresión en este género probablemente ofrezca resistencia a la inclusión en panoramas históricos o antologías. De alguna forma, el lector espera encontrar una prosa de las ideas fluida, una exposición que describa un problema y las reflexiones del ensayista en torno a él, sustentadas por argumentos, pero, por el contrario, encuentra la paradoja de una manifestación de ideas llena de metáforas que dificultan la lectura. Su famosa frase "una frase mía que he repetido: cuando estoy oscuro, escribo poesía; cuando estoy claro, escribo prosa" (LEZAMA, 1996, p. 713) se convierte en una demostración más de su espíritu lúdico. Una ironía sobre una claridad en la exposición que no es un atributo de su "prosa" ensayística.

Quizás sean estos aspectos los que no le permiten un lugar -en las antologías antes mencionadas- al lado de otro poeta reconocido también como ensayista: Octavio Paz. Pese a las semejanzas en el pensamiento de ambos, la escritura del mejicano, incluso con imágenes poéticas, es percibida de un modo totalmente diferente. Críticos dedicados al ensayo, como la argentina Liliana Weinberg en su texto Pensar el ensayo, lo incluyen como ejemplo del lazo entre el ensayo y la poesía. La hipótesis más convincente muestra que en los ensayos del mexicano los préstamos de la poesía no desplazan a la prosa de ideas sino que le otorgan al texto una velocidad diferente dada por la inmediatez de la imagen.

Otras posibilidades, al margen de la inclusión o exclusión de los ensayos lezamianos en un canon hispanoamericano del género, son las que se refieren a la naturaleza misma del género ensayístico y a la presencia de una crítica creativa. En este sentido es válido repensar el ensayo desde la perspectiva de Alberto Giordano. En Modos del ensayo. De Borges a Piglia, este crítico sitúa a la lectura como el eje de la estrategia ensayística. El ensayista, "lectorbricoleur", mantiene una interrogación sobre lo leído y se sitúa en un lugar polémico e incómodo de la tradición privilegiando de esta forma la emergencia de lo nuevo. Lector impertinente, el ensayista también -y esto es fundamental en relación a José Lezama Limaestá “en una relación de intimidad con el azar", privilegia la forma sobre el contenido y aplica 
una verdadera "literaturización" del saber (GIORDANO, 2005, p. 223-242). Estos últimos rasgos, únicos en el ensayista literario, merecen una especial atención para el caso que nos ocupa.

De todos modos, frente al género ensayístico (y pensamos estrictamente en el literario) surgen varios interrogantes. Si la transdisciplinariedad propia de quien escribe con el espesor literario -y no como el especialista- y la presencia del azar evidencian una heterogeneidad en los materiales y un tratamiento dispar del tema, ¿es posible encontrar una formulación metodológica del arte? ¿Son textos que realmente hacen del poeta crítico de arte un mediador entre el artista y el público? Una hipótesis probable es pensar que la literaturización del saber sobre artes plásticas que opera en estos escritos hace parte de su propia postura y de su concepción frente a la relación entre ambas artes, una posibilidad que intentaremos demostrar en las siguientes páginas.

\subsection{HACIA LA CRÍTICA DE ARTE: SITUACIONES Y PARADOJAS}

En uno de los ensayos presentes en la compilación Historia de las ideas estéticas y de las teorías artísticas contemporáneas, Francisco Calvo Serraller señala el surgimiento de los salones bajo el reinado de Luis XIV en Francia como la situación que potencia el mercado, colabora con la difusión social del arte y, sobre todo, “[...] fundamenta el nacimiento de la crítica de arte como profesión" (CALVO, 2004, p. 158). Con la exposición de las obras a un público que no poseía ninguna orientación y que no podía recibir alguna ni de artistas (cuya opinión podría ser parcial), ni de teóricos académicos, surge un intermediario que guía el gusto estético. Eran periodistas o intelectuales surgidos al amparo de las publicaciones periódicas, medios donde aparecían constantemente las crónicas de actualidad, incluida, claro está, la artística. Más que periodistas en el sentido de cómo se comprende esta profesión hoy, el crítico de arte es "un escritor, y, como tal, valorado en función de su capacidad retórica de sugestión literaria, al margen de su capacitación técnica para emitir juicios artísticos especializados" (p. 159). Como el crítico escribe para unos espectadores aficionados, su habilidad reside en una escritura adecuada, sugerente, y no tanto en un conocimiento profundo. De ahí que su obligación se restrinja casi exclusivamente a escribir bien, a adaptar su estilo a sus lectores para influir en ellos, pero también debe ser un intérprete de la opinión 
pública. Es una operación que se situaría en ambos campos, tanto el del conocimiento de la perspectiva del espectador y de sus expectativas, como el de la autoridad otorgada por una instrucción y por el pertenecer a algún medio de comunicación. Como señala Francisco Calvo Serraller, en el naciente periodismo el crítico de arte era un "cazador de oportunidades" que, al forjar el éxito de un artista, estaba al mismo tiempo creando una reputación que le proporcionaba poder (p. 159).

Ahora bien, si los inicios de la crítica de arte deben situarse en la Francia de los salones, con un reciente periodismo y una figura burguesa de provincia sin mucho dinero, que generalmente simpatizaba con el ideario revolucionario, ¿cómo se va gestando en Hispanoamérica esa figura del escritor de profesión (poeta, ensayista o novelista), quien también se arroga la función de opinar y escribir sobre arte? Desde el comienzo, la situación de la crítica de arte está sujeta a la escritura, pero no a la de cualquier tipo. Es la figura del escritor la que emerge como guía, pues "escribe bien", posee sensibilidad y gusto estético. En Francia la lista de escritores destacados que ejercieron la crítica de arte comienza con Diderot, en el siglo XVIII, y continúa con Baudelaire, Balzac, los hermanos Goncourt, Zola y Maupassant, en el XIX, pero también con Apollinaire, Breton, Eluard y Malraux, en el siglo XX. En Hispanoamérica sobresale el caso de los modernistas a finales del siglo XIX y de poetas reconocidos del siglo XX, como Luis Cardoza y Aragón, Octavio Paz y José Lezama Lima, entre muchos otros.

Con el modernismo se conjugan las formas parnasianas, apegadas a una poesía de la visión, de la pintura y la escultura, con las maneras simbolistas y su prevalencia de los elementos sonoros y musicales. Esta observación, aplicada a la segunda generación modernista, de acuerdo a la perspectiva de Octavio Paz en "El caracol y la sirena" (Rubén Darío) (PAZ, 1991, p.11), nos recuerda la importancia que la creación de un cuadro, mediante un lenguaje poético evocador del color, opera en el movimiento modernista. No obstante, será desde otro género, el de la crónica, que escritores como José Martí elaboran crítica de arte desde uno de los centros autorizados de la modernidad: Nueva York. Al respecto, cabe recordar dos de sus textos más reconocidos: "Nueva exhibición de los pintores impresionistas" y "La exhibición de pinturas del ruso Vereschagin", ambos publicados en el periódico $L a$ Nación de Buenos Aires en los años de 1886 y 1889, respectivamente. Crónicas que informan al público de ese país lo que sucede a nivel artístico en la capital neoyorquina, pero que también evidencian a un Martí conocedor de las corrientes naturalista e impresionista. En ellas 
caracteriza al impresionismo con sus efectos de luz y color, nos recuerda la impronta de los españoles Diego Velásquez y Francisco de Goya en esta escuela francesa y resalta el vínculo entre el arte y la libertad (sobre todo para el caso de la pintura del ruso) (MARTÍ, 1992, p. 2327 ; 254-262).

El comienzo de una crítica de arte, realizada en Hispanoamérica hacia finales del siglo XIX con el modernismo, tendrá continuidad en el ejercicio crítico de poetas como Luis Cardoza y Aragón, Octavio Paz y José Lezama Lima. Una crítica escrita en un lenguaje poético, donde parece primar la idea de "obra de arte" como un producto diferente de los elementos cotidianos y elaborado mediante una técnica o artesanía por parte del artista. Aunque Paz escribe un libro sobre su amigo Marcel Duchamp ${ }^{4}$, su concepción acerca del objeto estético está guiada por la visión, por el acto contemplativo que presupone una obra para su interpretación. Los escritores mencionados desarrollan en sus percepciones una conciencia crítica de la modernidad enmarcada, sobre todo, en un arte figurativo o abstracto anterior a los años sesenta, pero no en un arte conceptual. No obstante, y pese a este importante recorte, la labor de estos poetas como críticos de las expresiones visuales es sobresaliente, inclusive porque algunos de ellos fueron directores de revistas, donde el debate sobre el tema artístico sobrepasó fronteras geográficas, como es el caso de Orígenes, publicación dirigida por José Lezama Lima y José Rodríguez Feo, que contó con la participación directa de artistas de la isla y cuyos textos abarcaron el arte nacional y el extranjero.

Frente a una crítica de arte ejercida por destacados escritores hispanoamericanos existe también una paradoja: los textos sobre este tema no sobrepasan un puñado. Por ejemplo, Rafael Acosta de Arriba en su artículo "Octavio Paz y la crítica de arte, un lugar de encuentro para el pensamiento", menciona solamente a los críticos Ruy Sánchez, Mary Farakos, Antonio Luque y Conrado Tostado como los únicos que se han aproximado al trabajo crítico en el campo visual del poeta mejicano (ACOSTA DE ARRIBA, 2007, p. 26). Inclusive en el caso de la celebración del centenario de nacimiento de José Lezama Lima en el año 2010 en La Habana, los estudios sobre su crítica de arte fueron básicamente escritos por dos autores:

\footnotetext{
${ }^{4}$ Es el libro titulado Apariencia desnuda: la obra de Marcel Duchamp (1973) y en el que Paz completa otro texto de 1966 llamado Marcel Duchamp o el castillo de la pureza. El origen de esa ampliación es una exposición retrospectiva del artista francés organizada por el Museo de Arte de Filadelfia y el Museo de Arte Moderno de Nueva York en 1973.
} 
Roberto Méndez y Reynier Espinosa ${ }^{5}$. En las otras ciudades donde también se celebró esta conmemoración, como México D.F, no fue presentada ninguna ponencia sobre este tema, y en el Congreso Internacional "El Caribe en sus literaturas y culturas", celebrado en Córdoba (Argentina), tampoco hubo ninguna mención al asunto. En otras palabras, nos encontramos ante un vacío que en realidad tiene más de cuatro años y que demuestra la escasez del análisis en este ámbito.

No obstante, y a pesar de esta ausencia de estudios sobre el tema, no podemos dejar de lado la importancia de este quehacer crítico, no solamente para orientar al público sino también para mostrar la situación del campo artístico ${ }^{6}$. En esta dirección, es el escritor quien asumió (y todavía asume) en Hispanoamérica la tarea de analizar algunas corrientes y la obra producida por artistas (nacionales y extranjeros) representativos de su tiempo, de la misma forma que los escritores franceses antes mencionados. Sin embargo, una diferencia notable entre el contexto artístico francés y el medio cultural hispanoamericano es la voluntad en el primero- con los pintores Pisarro y Gauguin, en primer lugar- de intentar liberarse de los literatos con sus comentarios que se superponen (y, a veces, reemplazan) a la obra, mientras que en Hispanoamérica no pareciese existir esta voluntad de separación ${ }^{7}$. Tal vez porque los escritores realizan también una labor de divulgación ${ }^{8}$, crucial para la difusión del arte y de los artistas.

\footnotetext{
${ }^{5}$ El texto de Roberto Méndez se llama "La sonrisa acumulativa e indescifrable del cubano. José Lezama Lima y las artes plásticas" y puede encontrarse en la página web de la Academia Cubana de la Lengua (http://www.acul.ohc.cu/sonrisa_acumulativa.pdf.). En cuanto a Reynier Espinosa, su trabajo, “José Lezama Lima ante la creación pictórica de su tiempo", está publicado directamente en la página web que recoge todas las ponencias del Coloquio Internacional por el Centenario de José Lezama Lima "A partir de la Poesía: La era Lezama" (http://www.cce.co.cu/coloquio_lezama/resum_ponen.htm).

${ }^{6}$ Según Pierre Bourdieu, la idea de "campo" -sea literario o propio del arte plástico- corresponde a un sistema artístico autónomo de las esferas social y política, y de instituciones como el Estado, la Academia, el periodismo, con una marcada anomia, pues no existe una figura que pueda arrogarse la autoridad de dictar normas (BOURDIEU, 2002).

7 Hemos querido extrapolar el concepto de "campo", que Bourdieu observa vinculado al contexto social, económico y político de la Francia decimonónica, y observarlo brevemente en lo que creemos es el "caso hispanoamericano". En cuanto a este último, hay claras diferencias con el contexto galo, donde, de acuerdo a este sociólogo, los pintores buscaban la autonomía de la imagen pictórica (estamos todavía en un arte figurativo) frente al discurso. Este anhelo de los artistas plásticos de separarse de los literatos comienza con Manet y los impresionistas, para quienes la representación "fiel" de la realidad en la expresión artística pierde importancia.

${ }^{8}$ Es bastante compleja la tarea de analizar una "génesis del campo literario y artístico hispanoamericano". Más bien, pensamos en la idea de campo como un sistema con sus dinámicas y tensiones propias, y relativamente autónomo (como él mismo Bourdieu admite). Allí el rol del crítico proveniente del medio literario se asemejaría, en el caso hispanoamericano, no solamente a alguien que emite un juicio de valor y describe lo representado en un cuadro, sino que también ilustra las relaciones del artista con el capital colectivo, es decir, con la tradición. De esta forma, no pretendemos profundizar en las tensiones entre las fuerzas política, social y
} 
La brecha entre artistas plásticos y escritores parece tener su advenimiento en Hispanoamérica con el arte conceptual. Esta es una hipótesis preponderante en un texto del artista y curador Pablo Helguera sobre la crítica de arte de Octavio Paz. De acuerdo a Helguera, este poeta manifiesta una gran curiosidad para entender el performance art, pero a la vez se resiste a percibir en la obra de Duchamp una nueva forma artística que representa una libertad frente al "asunto" susceptible de ser asumida por otros creadores. Para este artista, la preferencia por un arte figurativo es una marca de los textos de Paz y de la mayoría de escritores que al aproximarse a las expresiones visuales dejan de lado a artistas contemporáneos que han tenido un impacto profundo como Lygia Clark, Hélio Oiticica, Ana Mendieta, Cildo Meireles, Felix González-Torres, Doris Salcedo, Alfredo Jaar, y Gabriel Orozco, entre otros (HELGUERA).

Con el borramiento de las fronteras de lo que normalmente se considera estético de aquello que no lo es, parece hacerse necesario un conocimiento mayor de filosofía, historia, sociología y algunas otras disciplinas que ayuden a la comprensión de este tipo de manifestaciones. Pese a que Octavio Paz o José Lezama Lima posean una vasta erudición solamente por tomar dos casos-su crítica se centra en artistas específicos, gracias tal vez a que como el primero reconoce "el arte moderno: es el arte de mi tiempo" (PAZ 1994, p. 23). Manifestaciones de finales de los sesenta, o lo que los críticos denominan "arte contemporáneo", no interesan especialmente a Paz, quien justifica su pasión crítica por la pintura y la escultura al compararla con códigos más abstractos como la música o que requieren un sistema conceptual como la arquitectura:

Tal vez porque el código de la pintura es más sensual, menos abstracto y riguroso que el de la música. El lenguaje de la pintura -líneas, colores, volúmenes- entra literalmente por los ojos; su código es primordialmente sensible [...]. Los significados de la pintura están a la vista (PAZ 1994, p. 25).

El arte al que se refiere Paz presupone la contemplación atenta del espectador, es decir, es un arte que no rompe con la representación. Con algunas variantes lo mismo sucede en la crítica de arte de José Lezama Lima. El cubano no se centra en el arte conceptual y su mirada sobre las vanguardias es problemática ${ }^{9}$.

económica y el medio artístico (siempre existentes de alguna manera) sino en enunciar el medio visual como atravesado por un discurso que lo divulga y que es también una herramienta pedagógica.

9 De acuerdo a Helguera, la premisa kantiana en la que "la apreciación de la belleza de una obra de arte requ[iere] una contemplación estética desinteresada"(HELGUERA) es reinterpretada por Ortega y Gasset, para quien el artista realiza un acto de contemplación interno que conduce a la creación de una obra susceptible de 
Una última realidad de la crítica de arte elaborada por escritores poetas es la relación con los artistas, la asistencia a exposiciones o el contacto directo con la obra. Cabe destacar aquí una notable diferencia entre Lezama Lima y Octavio Paz. El primero que no salió verdaderamente de Cuba (solamente realizó viajes cortos a México y a Jamaica) y que debía atenerse a las informaciones sobre arte que llegaban sesgadas a la isla desde los centros culturales ${ }^{10}$; el segundo, que traba amistad con los artistas mexicanos y franceses (Duchamp, por ejemplo) y que gracias a sus cargos diplomáticos puede viajar constantemente y encontrarse frente a la obra, en museos y exposiciones. La forma a través de la cual llega la información sobre las corrientes y los artistas del momento determina también la manera como se asume la crítica de arte, al menos en el caso del poeta habanero. El acceso bastante restringido a la información sobre los eventos artísticos que tienen lugar en el exterior $-\mathrm{y}$, sobre todo, en centros como Nueva York o París- causa el desconocimiento o el conocimiento a medias de algunas zonas del arte. También es relevante señalar que es recién a mediados de la década del ochenta (1984) cuando surge un proyecto de trascendencia internacional para Cuba y para el Caribe: la Bienal de la Habana. Como advierte Yolanda Wood en "Arte del Caribe, el decenio que terminó el siglo XX”, las últimas tres décadas del siglo XX marcaron, desde diversas perspectivas y enfoques, momentos de confrontación y diálogo entre artistas, críticos y curadores del Caribe, Latinoamérica y "más allá". Entre estos eventos están, además de la bienal en la capital cubana, la Bienal del Grabado Latinoamericano en San Juan de Puerto Rico (1970) y la Bienal de Pintura del Caribe y Centroamérica de 1992 en Santo Domingo (República Dominicana) (WOOD).

Puede ser que los artistas de la isla hayan sido más afortunados que los críticos. Al menos dos de los plásticos con más renombre en el medio -Amelia Peláez y Wifredo Lam-y que

ser interpretada y explicada mediante hipótesis. Esta visión orteguiana dará lugar a la gran libertad interpretativa de los escritores frente al hecho estético; libertad en la que surgiría un género híbrido entre la crítica y la poesía. Una reflexión que, siguiendo el texto de Pablo Helguera, inspira directa o indirectamente a pensadores como Samuel Ramos o al grupo de los Contemporáneos conformado por Salvador Novo, Xavier Villaurrutia y Gilberto Owen. Octavio Paz tampoco se sustrae de este influjo.

${ }^{10}$ Luz Merino Acosta en su texto "Orígenes: otra cara de la modernidad" señala la forma de acceso a los discursos producidos en los centros artísticos tradicionales. "Las fuentes de estas gramáticas serán diversas: las revistas ya mencionadas [Proa, Forma y Avance], las exposiciones coyunturales, algún viaje a los Estados Unidos y otro país que permitiera la confrontación con un universo de configuraciones formales" (ACOSTA, 2000 , p. 26). En el caso de Lezama, la ausencia de viajes reduce las posibilidades de contacto directo con las obras y los artistas, pero la mediación queda a cargo de Rodríguez Feo, quien, a partir de su estancia académica en Estados Unidos, es el encargado de obtener las colaboraciones y traducir a los principales poetas de lengua inglesa que interesaban a los miembros de una publicación como Orígenes: T.S Eliot y Wallace Stevens, entre otros. 
estuvieron vinculados al proyecto origenista de formas diferentes, recibieron una formación artística en París que los puso en contacto con otros creadores y con otras formas de concebir el arte. Además, el estudio en una academia en la capital francesa representaba una forma de acreditación a la hora de exponer y presentar trabajos ya de regreso a La Habana. Un contacto que revela la relación centro-periferia y el lugar de la mediación para los artistas plásticos y para los escritores hispanoamericanos. Desde esta óptica, el pintor pretende un aval estudiando y actuando en un ambiente extranjero considerado como uno de los ejes de la cultura occidental, y el escritor -sin acceso pleno y directo a las piezas estéticas- reflexiona a partir de la lectura e interpretación de otros acerca de las expresiones visuales, de la palabra de terceros igualmente reputados. Una intervención sustancial que nos permitirá caracterizar el ejercicio crítico de nuestro autor y sus arquetipos estéticos y teóricos.

\subsubsection{Baudelaire, Lezama y Casal: las mediaciones}

Dos poetas nos permiten una configuración inicial de la escritura lezamiana sobre arte. Uno de ellos es Charles Baudelaire, el otro es Julián del Casal. La incorporación de ambos aquí obedece a que el primero revoluciona y modifica la manera descriptiva y normativa de la función del crítico que lo caracterizaba hasta ese momento hacia una concepción donde intervienen la subjetividad y la creatividad, mientras que el segundo -poeta modernista nacido en La Habana- desarrolla una expresión poética sobre el pintor Gustave Moreau que, al igual que José Lezama Lima, depende de la intercesión de un tercero, ya que no tiene cómo ver las obras originales y depende de las copias que le envía Joris-Karl Huysmans. De esta manera, y a partir de estas circunstancias compartidas por los dos autores de la isla, nos interesa observar los procedimientos mediante los cuales podemos hablar de la emergencia de una críticapoética al modo de Baudelaire, cuando en su famoso ensayo A quoi bon la critique? consigna que el "mejor informe de un cuadro podría ser un soneto o una elegía" o un poema ecfrástico. Igualmente nos interesa la forma como Lezama lee a Baudelaire a través de su ensayo sobre Julián del Casal (“Julián del Casal”), una lectura acerca del modernista que orbita alrededor del surgimiento de un sujeto crítico.

Esta misma noción baudeleriana acerca de que el mejor método de crítica es el poético justifica, en gran medida, la comparación entre el poeta modernista y nuestro autor a partir de la serie de sonetos publicados en Nieve ("Mi museo ideal" y "Marfiles viejos"), del primero, y 
del conocido poema "Oda a Julián del Casal", del segundo ${ }^{11}$. De acuerdo a Oscar Montero, los sonetos de "Mi museo ideal" "fueron el resultado de un intenso intercambio epistolar que Casal inició con Huysmans y con Gustave Moreau”, cuyas pinturas -o mejor, copias- obtenía a través del autor de À rebours. Esta imposibilidad de gozar de los originales y la dependencia de terceros para ver las obras plásticas son circunstancias similares a las del propio Lezama, y, en otro sentido, los sonetos casalianos representan un modelo de crítica creativa con respecto al arte plástico susceptible de ser equiparado con el poema de aquél.

Una interpretación que nos parece central alrededor de "Mi museo..." es la de Montero cuando afirma que los versos del modernista no son una descripción o un calco de los grabados y sí "una visión poética propia cuyo protagonista es el poeta" (MONTERO). Así, en el soneto introductorio tenemos un retrato del artista, en los diez sonetos "una tensión entre un principio creador y una energía benéfica y devoradora [la inspiración]” y en el poema final hallamos una deificación de Moreau que, siguiendo a Montero, "destierra la figura del poeta, [...] la coloca fuera del marco de los cuadros del museo" (MONTERO). La entidad enunciativa en estos poemas, que no podemos confundir con la del bardo, emplea el intertexto pictórico en la reflexión y en el compartir con el pintor ese estado alterado de fuerzas opuestas que lo atraen. En consecuencia, hallamos mayormente una meditación apreciativa acerca del acto de la creación pictórica y poética que se sustenta en los lienzos y, en menor medida, un análisis que parte de la propia figura del creador plástico, descrita en "Vestíbulo" como "rostro que desafía los crueles / rigores del destino; frente austera / aureolada de larga cabellera" (CASAL, 1982, p.139).

En contraste, José Lezama Lima elabora en "Oda a Julián del Casal” una composición lírica donde realza la figura del modernista a partir de varias estrategias, entre las que sobresalen una notoria visualidad y el predominio del color verde como la tonalidad de los ojos del poeta y como una referencia a la vida, a la naturaleza, pero también -y gracias a la presencia de personajes míticos y de la religión como Adonis/Adonai- al orfismo. Recordemos los versos:

[...] La misión que te fue encomendada, descender a las profundidades con nuestra chispa verde $[\ldots]($ v. 165-166)

\footnotetext{
${ }^{11}$ Decimos que sustenta este cotejo porque sin la intervención de Baudelaire en la promulgación de esta nueva crítica no podemos pensar en los poemas de Casal ni en la crítica de arte de Lezama. Un telón de fondo que tendrá más desarrollo en las líneas siguientes, cuando nos dediquemos al autor de Las flores del mal a través de las reflexiones de Bourdieu, de sus propios escritos y de la lectura lezamiana de Casal. Una mirada que no será la única a lo largo de este escrito.
} 
[...] Pues todo poeta se apresura sin saberlo

para cumplir las órdenes indescifrables de Adonai [...] (v. 169-170)

[...] quisiste llevar el verde de tus ojos verdes

A la terraza de los dormidos invisibles (v. 172-173) (LEZAMA 1994B, p. 368)

En líneas generales, con la "Oda..." Lezama se inscribe y continúa en la estela de una crítica-poética que proviene del siglo XIX y que, desde esta visión, no se instala necesariamente en el ensayo ${ }^{12}$. Una política de continuidad que busca plasmar un ideal crítico donde se muestran varias intenciones. Entre ellas, la voluntad de alejamiento de un discurso en prosa que, por poseer un lenguaje mayormente denotativo, permite la presencia de conceptos y teorías; la búsqueda de una verdadera libertad expresiva en la poesía; y, en tercer lugar, el anhelo de una escritura crítica que pueda ser un espejo de la expresión artística plástica, esto es, que cree imagen.

Ahora bien, es imperativo retornar a Baudelaire y a la configuración de este nuevo "juez" estético. Uno de los rasgos que favorece un cambio radical es el momento en que él altera la noción vaga de ideal en favor de las "correspondencias". De acuerdo a Bourdieu en As regras da arte, esta innovación provoca que la tarea del crítico como juez, que se apoya en reglas "formales y universales", sea reemplazada por la de un analista e intérprete que se somete a la obra para buscar en ella la intención profunda del autor (BOURDIEU, 2002, p. 85). Una nueva actividad que tiene dos consecuencias: el uso de la creatividad, y no de una paráfrasis explicativa, y el surgimiento del artista nomóteta o creador que puede dictar las propias normas de su labor creativa; dos resultados directamente relacionados con la formación de un campo ajeno a normas dictadas por los estamentos político, académico, religioso, etc.

No obstante, Baudelaire también escribe sobre el lugar de promulgación de este nuevo examinador, que se alejaría de la adecuación de una obra de arte a unas reglas dadas a priori. Un abandono que, en sus palabras, aparece gracias a la intervención de un juicio subjetivo siempre "apasionado". En A quoi bon la critique?, leemos:

Yo creo, sinceramente, que la mejor crítica es la que resulta entretenida y poética; no esa otra fría y algebraica que, bajo pretexto de explicarlo todo, no tiene ni odio ni amor y se despoja voluntariamente de toda especie de temperamento; pero como un hermoso cuadro es la naturaleza reflejada por

\footnotetext{
12 Otro tipo de situación de crítica-poética se revela en los poemas lezamianos "Pequeña oda a Víctor Manuel García", "Nuevo encuentro con Víctor Manuel", "Ronda sin fanal" (para Mariano Rodríguez), "De la primera glorieta de la amistad" (para René Portocarrero) y de las “Décimas de la querencia” (para Luis Martínez Pedro). En ellos la perspectiva crítica está mediada por la amistad.
} 
un artista, la mejor crítica será ese mismo cuadro, reflejado por un espíritu inteligente y sensible. De modo que el mejor informe de un cuadro podría ser un soneto o una elegía.

Pero ese género de crítica está destinado a los volúmenes de poesía y a los lectores poéticos. En cuanto a la crítica propiamente dicha, espero que los filósofos comprenderán lo que voy a decir: para ser justa, es decir, para tener razón de ser, la crítica debe ser parcial, apasionada, política, esto es, realizada desde un punto de vista exclusivo, pero que sea el punto de vista que abra el mayor número de horizontes. ${ }^{13}$

La persistencia de un gesto valorativo por parte del crítico, de un punto de vista que motive en el lector una apertura a nuevas interpretaciones, será el gran legado de este poeta y una especie de "carta blanca" para los escritores que, con el surgimiento de la prensa, trabajan como cronistas y críticos de arte. La otra herencia, aquella que nos interesa más, es posible medirla en el ensayo de Lezama dedicado a Julián del Casal y publicado en Analecta del reloj en 1941. En él traza un paralelo entre el modernista y Charles Baudelaire que merece nuestra atención por el perfil de este último.

Dos elementos sobresalientes son su extensión y la presencia de una primera parte que se convierte en el marco del texto entero. En ésta, el poeta cubano expone su concepción sobre la crítica, su noción de un razonamiento reminiscente y su postura frente al análisis literario en la isla. De esta forma, la idea de un raciocinio que opere por el recuerdo, y los nexos entre los detalles rememorados y el texto, evita una noción de influencia sin matices, al mismo tiempo en que justifica la recuperación hecha por Lezama Lima de Casal; una justificación que se sustenta en el ataque al dispositivo crítico del XIX en "manos de profesores mansuetos y de pasivos archiveros" (LEZAMA, 1977, p. 82) que solamente percibe su afrancesamiento.

Por otra parte, las seis partes en las que se divide el ensayo pueden ser resumidas en tres, de acuerdo a nuestro interés en Baudelaire, y no en Julián del Casal. Así, esta tríada estaría conformada por el término "reducción-reducciones" y la percepción de Baudelaire como

\footnotetext{
${ }^{13}$ Je crois sincèrement que la meilleure critique est celle qui est amusante et poétique; non pas celle-ci froide et algebrique, qui, sous prétexte de tout expliquer, n'a ni haine ni amour, et se dépouille volontairement de tout espéce de tempérament; mais -un beau tableau étant la nature réfléchie par un artiste, celle que será ce tableau réfléchi par un esprit inteligente et sensible. Ainsi le meilleur compte rendu d'un tableau pourra être un sonnet ou une élégie.

Mais ce genre de critique est destine aux recueils de poésie et aux lecteurs poétiques. Quant à la critique proprement dite, je espère que les philosophes comprendront ce que je vais dire: pour être juste, c'est-à-dire, pour avoir sa raison d'être, la critique doit être partiale, passionnée, politique, c'est-à-dire, faite un point de vue exclusif, mais un point de vue qui ouvre le plus d’horizons. (BAUDELAIRE, 1992, p. 78) (La traducción es mía).
} 
crítico; las nociones de esteticismo y dandismo; y el lazo entre el dandismo y el catolicismo con su reflexión sobre la sobrenaturaleza.

Un primer encuentro con el autor europeo exhibe su vocación crítica: "Baudelaire ofrecía una reducción, en la que alternaban las indirectas delicias de los olores con su devoción a la máquina pensante" (p. 73). Una habilidad y un uso del pensamiento en relación a las sensaciones que le permite detenerse en ellas y buscar también un sentido más profundo. Una "reducción" o "reducciones" (Lezama parece usar indistintamente el singular y el plural de este vocablo) como selección de una parte de la experiencia -en este caso sensorial- que le permitirá construir una noción de trascendencia y de una unidad donde existen las correspondencias; logro que no alcanzará Casal, aun cuando esté dotado de la "madurez poética" suficiente que le permite recibir y comprender la tentativa del francés.

Las reflexiones en torno al esteticismo y al dandismo son centrales en el ensayo. Con respecto a ellas, ambos asumen posiciones extremas, no sin algunas contaminaciones. Así, Casal asume la posición de esteticista y Baudelaire la del dandy, aunque el primero se acerque a la postura estética opuesta por su percepción sobre la mujer. En cuanto a Lezama, es clara su preferencia hacia el dandy, "en realidad el último de los artesanos de gran estilo que, carente de fe, termina convirtiéndose a sí mismo en piedra y se labra constantemente", pues "en la repulsa el dandismo se muestra más decidido que el esteticismo" (p. 86). Mientras que éste no se solaza en el mundo exterior y prefiere su mundo interior, su soledad, su hastío, el seguidor del esteticismo siente gusto por la belleza de las cosas, por la evocación simple que no ahonda en la subjetividad, aunque sí en el nombrar de objetos "burgueses" y en las experiencias sensoriales que producen.

La importancia del dandismo en el ensayo sobre Julián del Casal se manifiesta claramente en su coincidencia con el "antropocentrismo católico" y lo "natural excesivo". Para el escritor neobarroco, en el esteticismo existiría un regodeo en el mundo exterior, en las pompas y en el snobismo, mientras que el dandismo "termina en Charles Baudelaire, [acaba] buscando el paraíso revelado y las reducciones del pecado original” (p.88). El gran tema de la poesía baudeleriana es precisamente ese clamor, esa tensión entre la gracia y la caída, entre el pecado original y la salvación; una propuesta que no desarrolla Casal, a pesar de ser católico, y porque el esteticismo, que tanto critica Lezama, se lo impide. En esa línea argumentativa, lo "natural excesivo" está también del lado del dandismo como producto de una conciencia de esas tensiones que se manifiestan en la metáfora. Como afirma Lezama Lima: "lo natural que 
se excede, que impulsa al globo de fuego, reducido después a vellón o a paloma” (p. 89). Una creación de la metáfora que parte de la conciencia y no del sueño de los surrealistas mencionados también por él. De alguna forma, la presencia de un "natural excesivo" en este ensayo de 1941parece prefigurar la noción posterior de "sobrenaturaleza", que no es otra cosa que la intervención de la metáfora en la recreación de la realidad objetiva, del mundo físico.

En el retrato que Lezama hace de Baudelaire, así como en la importante perspectiva que ofrece Bourdieu, vemos un rasgo fundamental: la presencia de un sujeto crítico. Esta emergencia de la crítica como un ejercicio que parte del sujeto y no de una instancia validada por los estamentos social o educativo (la academia, por ejemplo) es necesario comprenderla como el marco de nuestra reflexión. Es desde esta mirada que el aporte de Baudelaire resulta tan importante, ya que como poeta (tal cual lo observa Lezama) y como crítico (en Bourdieu) el rasgo central es la persona, la subjetividad, y no una mera observación del mundo exterior.

\subsubsection{Los otros espectros de una crítica poética de arte: René Wellek y Northrop Frye ${ }^{14}$}

En "The poet, the Critic, the Poet-Critic", René Wellek se refiere al poeta que escribe crítica sobre poesía y juzga su verdadero alcance analítico. Comienza con el "Brief Treatise on the Criticism of Poetry" de T.S Eliot -autor al que volverá varias veces- y continúa con W.H Auden, Wilde y Valéry, entre otros, para mostrarnos que la unión entre la facultad creativa y la crítica no siempre tiene resultados felices. Según él, "el poeta [...] no ha dicho mucho sobre el proceso creativo, así él sea Valéry (M. Teste, que es “cabeza”) o el surrealista que confía en su subconsciente y en su escritura automática" ${ }^{15}$. Una falencia que asigna a los poetas-críticos que no es la única: Wellek también mencionará las que, a su juicio, son propias de aquellos que, desde la crítica, van hacia la poesía (Horacio, Boileau, Pope, Verlaine y

\footnotetext{
${ }^{14}$ El texto de René Wellek aparece originalmente en Discriminations: further concepts of criticism. Con Northrop Frye, nos hemos centrado en su trabajo The critical path: An Essay on the Social Context of Literary Criticism. El primero de estos libros fue publicado originalmente en 1970 y el segundo en 1971. Nos ha llamado la atención el trabajo de estos dos críticos en lengua inglesa porque permite, por una parte, una aproximación a una crítica escrita por poetas y, por otra, a la noción de literatura como pilar de los constructos social, cultural, religioso y político en cualquier sociedad. De acuerdo a este último planteamiento, un estudio sobre el alcance de la crítica de arte escrita por un poeta, ensayista y narrador como José Lezama Lima, recibe una mayor justificación.

${ }^{15}$ En el original encontramos: "The poet, it seems to me, has told us little about the creative process, whether he is Valéry (M.Teste, that is, "Head") or the surrealistic relying on his subconcious and on automatic writing" (WELLEK, 1970, p. 260).
} 
Shapiro), e incluye también comentarios sobre una meta-poesía con ejemplos de Holderlin, Rilke, Mallarmé y Wallace Stevens.

No nos detendremos minuciosamente en el análisis de Wellek sobre la unión poesíacrítica, pero sí lo haremos en uno de sus comentarios acerca de la crítica creativa. Según él:

La autoexpresión, incluso la autobiografía, tiene un propósito que por lo menos en las formulaciones teóricas podría estar totalmente separado del objeto "como realmente es", por lo tanto podemos concluir que esta forma de crítica podría aplicarse a obras de arte, pero en realidad tendría su punto de partida en cualquier objeto bajo el sol. Si realmente nos interesa la crítica como un conocimiento organizado, como interpretación y juicio de objetos públicamente verificables, debemos descartar la crítica poética como una irrelevancia. Hoy el pasaje de la Mona Lisa en Pater, la ostentación en la elocuencia de Swinburne, e inclusive las encantadoras reflexiones de Anatole France han perdido su atractivo y no representan ahora un peligro ${ }^{16}$.

El juicio de Wellek sobre la ausencia de actualidad de una crítica poética representa una objeción a esta labor por parte de los escritores. Una apreciación que no compartimos y que debe ser matizada, en el sentido que se refiere al medio artístico europeo con poetas y autores ingleses y franceses, y no al caso hispanoamericano. Como hemos señalado, aún hoy un puñado de escritores escriben crítica de arte (libros, textos para catálogos, artículos). Ahora bien, vale la pena preguntarse sobre el espesor literario de la crítica de arte lezamiana, su vigencia y su verdadero carácter teórico. Con un ensayista como él, parece imposible afirmar que su percepción del lazo entre la poesía y la pintura en su expresión crítica sobre los pintores de la vanguardia cubana haya caído en una especie de desactualidad. Sobre todo, cuando, como afirma Helguera, la relación entre el mundo literario y el visual en Latinoamerica "es vital siendo que los escritores fueron una fuerza primordial en la construcción de los modelos de soporte de la cultura" (HELGUERA).

Ahora bien, un elemento sobresaliente en el texto de Wellek es el de una crítica poética capaz de hablar de cualquier tema. El interrogante surge cuando la intromisión de la poesía altera la densidad de la reflexión y de un contenido teórico posible, y ocasiona desconfianza o, al menos, cuestionamientos sobre si realmente estamos frente a un contenido de este tipo. Aún

\footnotetext{
16 "Self-expression, even autobiography, is the aim, which, at least in the theoretical formulations, would be entirely divorced from the object "as it really is", and thus criticism, we may conclude, need to be concerned with works of art, but could have its starting point in almost everything under the sun. If we are concerned with criticism as organized knowledge, as interpretation and judgment of publicly verifiable objects, we must dismiss poetic criticism as an irrelevancy. Today the Mona Lisa passage in Pater, the ostentatious fireworks of Swinburne's eloquence, and even the charming reflections of Anatole France have lost their appeal and are no present danger". (WELLEK, 1970, p. 256) (La traducción es mía).
} 
así, también podemos plantearnos otras preguntas sobre qué sucede cuando la crítica se acerca a un sistema ficcional. Si nos cuestionamos sobre estas posiciones, es porque intentamos observar y analizar la forma en que crítica y poesía se relacionan, un telón de fondo que colaborará posteriormente para el análisis de la dimensión ficcional y poética de los ensayos sobre arte de Lezama.

Dos críticos han reflexionado sobre la crítica ficcional de Northrop Frye: René Wellek y Tzvetan Todorov. Para el primero, la crítica ficcional es actual, aunque la tilde como "una elaborada ficción que pierde toda relación con el conocimiento, la ciencia y el concepto"17 (WELLEK, 1970, p. 257). Su juicio, bastante severo, lo lleva a proponer que este tipo de crítica puede ser pensada como un nuevo género literario, que se distingue totalmente de aquella labor basada en un ideal de corrección interpretativa y en las leyes de la evidencia (p. 257). En cambio, Todorov parece más benevolente en su análisis sobre la propuesta del crítico canadiense. En uno de los capítulos de Crítica de la crítica ("Conocimiento y compromiso". Northrop Frye), este crítico literario rescata la voluntad de acercar aproximaciones internas y externas a la literatura y se detiene en dos ejes: la concepción de la autonomía del discurso literario y la ausencia de separación entre la literatura y los demás discursos de una sociedad (TODOROV, 1991, p. 92). Es en esta última idea donde entra en juego el concepto de mito de Frye y de que "todo lo que pertenece a la cultura es pertinente para la comprensión de la literatura" (p. 94). Un planteamiento importante para el tema que nos atañe porque abre el campo literario a todas las expresiones culturales. En este sentido, la crítica de arte puede ser pensada desde lo literario y no como un campo relativamente autónomo que, ligado al fenómeno estético -sea la expresión pictórica o la escultórica-, desarrolla su propia armazón teórica y es ejercido por un grupo selecto de especialistas.

En El camino crítico, Frye comienza a estudiar el concepto de "mito" en su etapa de cristalización, (el comienzo equivaldría a los relatos de dioses y héroes). De este modo, "un mito completamente desarrollado, o enciclopédico, encierra todo el conocimiento que es de mayor incumbencia [...]" para una sociedad, es decir, "desarrolla distintas ramas que cubren los aspectos de lo social, lo político, lo legal y lo literario” (FRYE, 1986, p. 32-33). El mito, un concepto de difícil definición, se convierte así en el armazón que contendría todos los discursos y todo el sistema de creencias de una colectividad determinada, y la literatura corresponde a su instrumento, pues “expone las posibilidades imaginativas de ésta, es decir, la

\footnotetext{
${ }^{17}$ En el original leemos: "his criticism is an elaborate fiction which loses all relation to knowledge, science and concept".
} 
gama total de ficciones, modelos, imágenes y metáforas verbales con que se elaboran todos los mitos de la incumbencia" (p. 86-87).

La percepción de Frye acerca de la crítica conduce a dos conclusiones importantes. Una donde la literatura es el sustrato de todas las construcciones sociales, culturales, religiosas y políticas (entre otras) que una colectividad puede desarrollar y, la que más nos interesa, la idea de ficción. La primera nos dice acerca de la presencia del discurso literario en todas las esferas de una cultura y justifica un estudio de la crítica de arte escrita por un poeta; la segunda, ya no a partir directamente de Frye, pero sí de los críticos que han comentado su obra, aporta un elemento clave en nuestra discusión: la presencia de la ficción como ordenadora del discurso. Esta sugerencia no aparece exclusivamente en la apreciación de Wellek sino en la misma forma de la Anatomía de la crítica de Frye, texto que a nivel discursivo incorpora el mecanismo de la fábula mediante su taxonomía a nivel de géneros, temáticas, imágenes, etc. Quizá al evitar un análisis concienzudo de una obra en su totalidad y aislar "creativamente" situaciones o elementos para elaborar una gran sinopsis, esta obra obtuvo la denominación de "ficcional". Sin embargo, el asunto va un poco más allá y se aproxima más que a una "anatomía" a una "autonomía" de la crítica. El mismo Frye, en su "Introducción polémica" a este libro, afirma:

Por consiguiente, defender el derecho de la crítica a existir a secas significa suponer que la crítica es una estructura del pensamiento y del conocimiento que existe por derecho propio, con cierta medida de independencia respecto al arte del cual se ocupa [...]. Una vez admitido el hecho de que el crítico tiene su propio campo de actividad y que dentro de ese campo tiene autonomía, debemos conceder que la crítica trata de literatura en un marco conceptual específico" (FRYE, 1991, p. 18-19).

Si Frye aboga por despojar al crítico de un papel subsidiario o esclavo con respecto al arte o al artista objeto de su trabajo y reclama autonomía, no podemos dejar de pensar en el ensayo sobre crítica de arte de Lezama. A la desconfianza de Wellek hacia la labor crítica del poeta y hacia la intromisión de la ficción en la crítica, debemos sumarle la posibilidad, tras la lectura de Frye (y de Todorov), de una exigencia lezamiana de autonomía en los ensayos que se sustenta en su misma densidad poética. Así, ¿es posible que los ensayos sobre arte de este poeta sean realmente un discurso literario autónomo sin ninguna funcionalidad para la teoría o la crítica de arte? Esta pregunta es polémica porque, al reclamar una autonomía desde el género ensayístico, corremos el riesgo de perder la funcionalidad de estos textos para la teoría 
o la crítica de arte. De todos modos, no se puede perder de vista que José Lezama Lima es esencialmente un escritor y no un crítico de arte.

\section{2 “PARALELOS...”: CONTRAPUNTO, ECFRASIS Y POIESIS UNIVERSAL}

Poetry is speaking painting.

Frank Rogers. Painting and poetry.

Un título como "Paralelos. La pintura y la poesía en Cuba (en los siglos XVIII y XIX)" deja entrever una estructura de contrapunto. El diálogo entre las dos artes, el "paralelo" entre ellas, las aproxima y las pone en relación. La forma como Lezama construye su ensayo invoca un vínculo, una poiesis universal donde la noción de creación es el eje que reúne a la poesía con la pintura y con la música (aunque este último lazo no esté muy desarrollado). Para el cubano, la pintura como arte del espacio no es ajena a la poesía como arte que se desarrolla en el tiempo. Así, desde las primeras líneas del texto encontramos una ecfrasis, una descripción de imágenes pictóricas cuyo protagonista es Cristóbal Colón:

Antes de saltar embebido las clavijeras amarras, el misterioso surcador Cristóbal Colón se aposenta demorado frente a unos tapices. Ha cruzado una poderosa llanura, lo que debe haberle producido la sensación de una navegación inmóvil, está en un extremo de Castilla la Vieja y entra para oír misa de domingo en la Catedral de Zamora [...]. Uno de los tapices entreabre las guerras de Troya, con el rapto de Elena. En el centro, una barca medieval de gran tamaño, los mástiles ganan la altura del tapiz, aparece un marinero de extraña catadura, muy barbado, soltando el ancla, otro marinero recoge las amarras. Rimas provenzales limitan el panel, en torno del mástil, como palomas. [...]. En los otros tapices las muertes de Aquiles, Troilo y Paris. Los caballos se recubren de unas gualdrapas tan guarnecidas como el manto que cubre el elefante de un rajá. Aparecen curvados barcos, como góndolas de la Serenísima. Debajo de los muros y las ruinas estallan las flores como llamas torneadas. Un caballero pisotea las rosas de más sonriente amanecer. Las interminables llanuras de flores se confunden con las más presuntuosas alfombras persas con motivos de venatoria. Cuando el Almirante va recogiendo su mirada de esos combates de flores, de esas escaleras que aíslan sus blancos como aves emblemáticas, el arquero negro cerca de la blancura que jinetea Tanequilda, y las va dejando caer sobre las tierras que van surgiendo de sus ensoñaciones, se ha verificado la primera gran transposición de arte en el mundo moderno. De esos tapices ha saltado a tierra, y los blancos fantasmales, las cabelleras de las doncellas y los arqueros sombríos han comenzado a perseguirlo y arañarlo (LEZAMA, 1994, p. 66-67). 
Sin embargo, no es la primera vez que se menciona al Almirante descubridor. Subyace en este fragmento una noción del origen y de lo americano, que se remonta al Diario de Colón mencionado por Lezama en el "Prólogo a una antología"18. En él, el navegante consigna:

[...] que vio caer, al acercarse a nuestras costas, un gran ramo de fuego en el mar. Ya comenzaban las seducciones de nuestra luz. Insistiendo en el misterio de sus visiones, el Almirante ve un gran perro cuya boca sostiene como una columna de madera, donde cree ver letras. Ve la esbeltez de las indias que caminan para saludarlo y anota la expresión muy esclarecedora al fijarse en su pelo: seda de caballo (LEZAMA, 1977, p. 995).

Pero no solamente un origen y una idea de americanidad están presentes en ese primer encuentro de Colón con la Isla. Se trata también de la fundación de un carácter nacional (y de lo americano) mediante el relato ficcional, gracias a la transposición de imágenes donde priman una imaginación o un delirio europeos. El propio ensayista, unas páginas más adelante, señala que "la imaginación europea, tanto la grecolatina, como la medieval, pasa en su totalidad a una nueva circunstancia" (p. 997). Esa nueva circunstancia, la realidad americana, es fundada gracias a la "imagen, la fábula y los prodigios" de un imaginario europeo que es personificado en las mujeres aborígenes, el chamán o sumo sacerdote indígena y los manatíes-sirenas. No se pueden olvidar las palabras que abren este prólogo: "nuestra Isla comienza su historia dentro de la poesía" (p. 995). Un origen poético que tendría como centro a la imagen y a la metáfora. Esta última representada en la "seda de caballo" como figura asociada al cabello de las mujeres indígenas, pero que Lezama convierte en la imagen de lo cubano y del mismo Martí, cuando al final de este texto el prócer es caracterizado como el poseedor de la "más honda fineza y la más invencible resistencia" (p. 1037).

Ahora bien, la descripción de imágenes pictóricas presente en "Paralelos..." es el inicio del diálogo entre la poesía y la pintura. Un relato donde las imágenes se suceden creando una acción, donde las flores aparecen para luego ser pisoteadas por un caballero, y una primera aproximación de la expresión visual a la poesía como creación de imágenes en el tiempo o en una sucesión temporal. Así, la imaginación del Almirante reconstruye una imagen que de estática se ha convertido en dinámica y que plantea una continuidad entre la representación del tapiz y la realidad: el desembarco de Colón en América. Una conexión entre las dos manifestaciones artísticas que enfrenta la distinción tajante elaborada por Lessing en su libro

\footnotetext{
${ }^{18}$ Este prólogo aparece originalmente en Antología de La poesía cubana (La Habana: Consejo Nacional de Cultura, 1965). Nosotros hemos tomado la versión de las Obras completas de José Lezama Lima en la Editorial Aguilar (Tomo II: ensayos y cuentos). México D.F.: 1977, p. 995-1038.
} 
Laocoonte ou sobre as fronteiras da pintura e da poesia, quien declara, en la traducción de Márcio Seligmann-Silva:

Se, portanto, a pintura, devido aos seus signos ou ao meio da sua imitação que ela só pode conectar no espaço, deve renunciar totalmente ao tempo: então ações progressivas não podem, enquanto progressivas, fazer parte dos seus objetos, mas antes ela tem que se contentar com ações uma ao lado da outra ou com meros corpos que sugerem uma ação através das suas posições (LESSING, 1998, p. 190).

Si bien la primera forma de vincular poesía y pintura es una ecfrasis, unas líneas más adelante en "Paralelos...”, Lezama apela a figuras como Baudelaire y Mallarmé. Estos poetas buscan integrar la poesía, la pintura y la música, y representan una justificación acerca del por qué este texto conjuga dos artes -la poesía y la pintura- en apariencia tan disímiles.

¿Qué brújula adoptar para la navegación de poesía y pintura cubana en siglos anteriores? [...]. Ni siquiera seguir a Ybrovac, en la Transposition d'art, dedicado a Les trophés, siguiendo a Theophile Gautier, que fue el verdadero maestro de esta manera, pero para lograr esas correspondencias entre los colores, las insinuaciones y los perfumes, es necesario una plenitud que nuestra expresión aún no ha alcanzado. Le parfum, la couleur et le son se répondent. Son incuestionables, pues, las relaciones de Baudelaire con la pintura de su época, como lo es también la poesía de Mallarmé, haciendo saltar el fauno en el contorno de la siesta, como lo haría también Debussy (LEZAMA, 1994, p. 67).

La importancia de Baudelaire es notoria por varias razones. La primera, por la presencia de una correspondencia entre las artes; la segunda, presente en la mención del vínculo de la poesía del francés con la obra de Ingres o Delacroix; y, la tercera, por la existencia de una noción de poiesis universal. En cuanto a la idea de crítica, ésta aparece como una operación que "aísla y separa" (p. 68) en contra del júbilo del sympathos que origina los paralelos, paralelos en los que Lezama resalta la no obviedad del vínculo entre ambas artes.

Otro aspecto que vale la pena resaltar en este fragmento es el de una carencia en "nuestra expresión" que impide plasmar la plenitud de las correspondencias. Aquí Lezama parece ignorar la perspectiva del modernismo y de uno de sus iniciadores: Rubén Darío ${ }^{19}$. En "El

\footnotetext{
19 No es un ignorar "a secas". En 1967, Lezama escribe un ensayo sobre este poeta en el que señala que, aunque su generación es "anti-Darío", existe un reconocimiento y una acción comprensiva hacia la obra del nicaragüense. Una comprensión cuyo contrapeso es la figura de Martí como verdadero simbolista: “Quizás Darío no lograse hacer del simbolismo su mansión, como en el caso de Martí, que sin ser simbolista parte de los secretos de una totalidad" (LEZAMA, 1981, p. 53). No es que Lezama no reconozca la importancia del modernismo hispanoamericano y su relación con el simbolismo, pero, con respecto a Darío, se trata de una comprensión totalmente diferente a la de Paz. En ella, Lezama solamente percibe una calidad formal y un contenido meloso o "azucarado" en la poesía dariana.
} 
caracol y la sirena", Octavio Paz señala que, para los modernistas hispanoamericanos, "el universo es un sistema de correspondencias, regido por el ritmo; todo está cifrado, todo rima [...] ser poeta no es ser el dueño sino el agente de transmisión del ritmo; la imaginación más alta es la analogía" (PAZ, 1991, p. 18-19). La gran innovación del modernismo es precisamente la observación de la poesía parnasiana y simbolista, y la transformación de la lengua a partir de la introducción de nuevos metros (y la recuperación de otros), de arcaísmos y de neologismos, como señala este ensayista (p. 16-17). Los modernistas creen en una unidad cósmica y también en una pluralidad, en una dispersión del ser en "formas, colores, vibraciones" (p. 19) que plasman en su poesía.

En otras palabras, en la poesía modernista hispanoamericana son incorporados temas musicales e imágenes plásticas de acuerdo a la idea de un universo donde los sonidos y los colores se corresponden. Desde esa mirada, su escritura crítica, analítica o descriptiva sobre las expresiones artísticas plásticas, está más orientada a la información y difusión de los artistas o al comentario sobre sus cualidades. No podemos perder de vista, que, como menciona Lily Litvak, los poetas modernistas eran básicamente cronistas ${ }^{20}$.

Más allá del modernismo como inicio de una literatura en lengua hispanoamericana, conviene retomar la noción de poiesis universal de Baudelaire, base y sustento del ensayo "Paralelos...". Este concepto mostraría que la idea de creación misma subyace a todas las artes y la imaginación es su motor fundamental. Pero no una imaginación que se origina en la nada e intenta crear una realidad. Marcel Raymond, en De Baudelaire al surrealismo, señala que la facultad imaginativa parte del mundo físico y lo organiza: "Ve en ella [la naturaleza exterior], no una realidad existente por ella misma [...], sino un inmenso depósito de analogías y también una especie de excitante para la imaginación” (RAYMOND, 1960, p.17). En las palabras del mismo Baudelaire, que Raymond cita a renglón seguido, "la imaginación dará un lugar y un valor relativos" a ese "almacén de imágenes y de signos", que es el universo visible (p. 17). Bajo esa perspectiva, cabe repensar la pintura paisajística -la más inmediata a esa physis - desde la percepción del artista. Ya no hay una pintura mimética de la naturaleza sino una idea del paisaje moderno donde interviene la imaginación como principio

\footnotetext{
${ }^{20}$ La crónica sobre exposiciones de arte es un género practicado por Martí. En cambio, "la valoración de la crítica artística de Rubén Darío hay que entenderla a través de filones diversos entre los que se incluye su propia obra poética". ("Rubén Darío y la obra de arte". Disponible en www.amadonervo.net/transmigraciones/pdf/dario.pdf. Consultada en: ago. 2012). Esta importante afirmación es sustentada por Litvak mediante el análisis de poemas como "Aguafuerte", "La ninfa" y "La isla de los muertos", o los comentarios sobre obras y pintores consignados en los Diarios, lo cual refuerza nuestra revisión de la concepción lezamiana sobre una ausencia americana del diálogo entre las artes.
} 
ordenador. Como lo formulara Baudelaire, la expresión pictórica no debería reducirse simplemente a ser una copia.

Confesaré, como todo el mundo, que la escuela moderna de paisajistas es singularmente fuerte y hábil; pero en ese triunfo y en esa preponderancia de un género inferior, en ese culto ingenuo de la naturaleza, no depurada, no explicada por la imaginación, veo una señal evidente de rebajamiento general [...]. Aún así es necesario hacerle justicia al Sr. Daubigny, ya que sus obras son generalmente poéticas, y yo las prefiero con sus defectos a muchas otras más perfectas, pero privadas de la calidad que lo distingue ${ }^{21}$.

Según Baudelaire, el valor de la imaginación es supremo a la hora de pensar en una pintura de paisaje que produzca una emoción en el espectador. El mismo artista es un traductor, pues debe traducir "un séntiment par un ensemble de matière végétal ou minéral" (BAUDELAIRE, 1992, p.320-321). Imaginación y sentimiento cumplen la función de instigar a la creación de una verdadera obra de arte y no de una copia del material natural, una entidad que existe per se y que no requiere de una imitación en el lienzo. Pero para no cometer esta mímesis también existe otro factor: la composición, que Baudelaire examina con respecto a la pintura y a la poesía.

La mayoría cae en el defecto que señalé al comienzo de este estudio: toman el diccionario de arte por el arte mismo; copian una palabra del diccionario, creyendo copiar un poema; pero un poema no se copia nunca: desea ser compuesto. Así, abren una ventana, y todo el espacio comprendido en el cuadrado, árboles, cielo y casa, asume para ellos el valor de un poema completo $^{22}$.

La composición no implica copiar cada uno de los elementos de ese paisaje observado y pintarlos en el cuadro o copiar una palabra del diccionario. Se trata, más bien, de un trabajo arduo de elaboración de una obra de arte en la que para cada elemento intervienen el sentimiento y la imaginación. Aunque parezcan demasiado obvias estas afirmaciones con

\footnotetext{
${ }^{21}$ "J'avouerai, avec tout Le monde, que l'école moderne dês paysagistes est singulièrement forte et habile; mais dans ce triomphe et cette prédominance d'un genre inférieur, dans ce culte niais de la nature, non épurée, non expliquée par l'imagination, je vois un signe evident d'abaissement general (...) Avant tout, cependant, il faut render à $M$. Daubigny cette justice que ses oeuvres sont généralement poétiques, et je les préfère avec leurs defaults à beaucoup d'autres plus parfaits, mais privées de la qualité qui le distingue“ ("Salon de 1859: le paysage" en Critique d'art suivi de critique musicale. Paris: Gallimard, 1992, p. 320-321) (La traducción es mía).

22 "La plupart tombent dans le défaut que je signalais au commencement de cette étude: ils prennent le dictionnaire de l'art pour l'art lui-même; ils copient um mot du dictionnaire, croyant copier um poème. Or un poème ne se copie jamais: Il veut être composé. Ainsi ils ouvrent une fenêtre, et tout l'espace compris dans le carré de la fenêtre,arbres, ciel et Maison, prend pour eux la valeur d'um poème tout fait" (BAUDELAIRE, 1992, p. 320-321).
} 
respecto a ambas disciplinas (en la poesía su obviedad es casi hiriente), en la pintura definen una posición frente a un lugar común. No se puede olvidar la postura de Baudelaire con respecto a la pintura mimética. Para el poeta francés este tipo de expresión no tendría ningún sentido porque ya la fotografía sería una expresión mejor. De modo que, la verdadera labor de los pintores presupone la creación a partir de la imaginación y no una copia de la realidad.

\subsubsection{Los tropos de la historia}

La justificación sobre el vínculo entre la poesía y la pintura continúa unas páginas más adelante en el ensayo con una reserva. Al mismo tiempo en que su autor afirma la aproximación de Baudelaire a la obra de Ingres o Delacroix [figura 21], también dice que esa proximidad "nos llevaría a rastrear y a negar la presencia de esos pintores en Las flores del mal" (LEZAMA, 1994, P. 68). Una restricción extraña en los paralelos lezamianos, ya que los ejemplos se extienden y las conexiones entrevistas con Delacroix y Daumier se trasladan a la mención de los impresionistas y a la modernidad. En palabras de Lezama:

No obstante, ningún pintor como Delacroix exaltaba en Baudelaire sus potencias de admiración. En su cuarteto "Lalo de Valence", sobre el retrato de Manet, donde el verso final, le charme inattendu d'un bijou rose et noir, está lleno de todo el encanto de Baudelaire, pero Manet será siempre el más maestro de los impresionistas y Baudelaire el más apasionado enemigo de la fugacidad de las sensaciones y del relativismo impuesto por las variantes de lo temporal en la apreciación de la belleza (LEZAMA, 1994, p. 69).

Aparece en esta parte una curiosa contraposición. Unas líneas antes, Lezama menciona la forma como Delacroix "exaltaba" la admiración de Baudelaire y a renglón seguido -cuando se espera otra observación sobre este pintor- nombra el cuarteto "Lola de Valence" (hay una errata en el texto de Paralelos: "Lalo" es "Lola") del poeta francés sobre una pintura de Manet. Las diferencias son claras: Delacroix realizaría una obra que resiste al tiempo porque representaría de alguna forma un ideal (eterno) de belleza, mientras que el impresionismo representa "la fugacidad" en la forma de apreciar lo que se convertirá en una obra de arte. Con respecto a esta última idea, pensamos en el impresionismo con su "adanismo visual" resaltado por Guillermo Solana en "Crítica y modernidad” (SOLANA, 2004, p. 333-345). Este crítico observa que el postulado del "ojo inocente", promulgado por Jhon Ruskin en sus Elementos del dibujo (1857), es la teoría precursora de la sensación visual de esta escuela pictórica. Según Ruskin, el "poder técnico de la pintura" se desprendería de una visión infantil que destierra conceptos y asociaciones táctiles. Habría así una inmediatez en la visión que 
buscaría el olvido de las obras vistas en museos o de la asociación de la imagen con un significado. Esa rapidez en la percepción que acaba resaltando el color y no necesariamente la adecuación del objeto pintado a la realidad es la que, de acuerdo al texto de Lezama, aparecería asociada a los rápidos cambios temporales. Posteriormente a los impresionistas habrá otra propuesta en la percepción de lo estético y así sucesivamente.

Ahora bien, también es necesario matizar la afirmación de Lezama sobre Baudelaire, pues, como él señala, éste no es necesariamente "el más apasionado enemigo de la fugacidad de las sensaciones y del relativismo impuesto por las variantes de lo temporal" (69) y su concepción sobre la modernidad es más compleja. Por una parte, se detiene en la ciudad y en su ritmo agitado, es decir, el culto a la naturaleza propio del romanticismo cede ante la vivencia en la urbe moderna; por otra, no pueden olvidarse sus citadas palabras sobre el carácter doble de la belleza moderna:

Lo bello está hecho de un elemento eterno, invariable, cuya cantidad es excesivamente difícil de determinar, y de un elemento relativo, circunstancial, que será, si se quiere, por turno o conjuntamente, la época, la moda, la moral, la pasión. Sin este segundo elemento, que es como el envoltorio entretenido, titilante, aperitivo, del divino pastel, el primer elemento será indigerible, inapreciable, no adaptado y no apropiado a la naturaleza humana. Desafío a que se descubra una muestra cualquiera de belleza que no contenga estos dos elementos ${ }^{23}$.

Un vínculo entre la pintura y la poesía que comienza con la ecfrasis, continúa con la enunciación de los vínculos entre pintores y poetas en el siglo XIX, y se detiene ahora en la imagen poética:

De esa manera hierve un color, se exalta o predomina una franja, un hilillo tiembla en la vibración del sonido, ¿cómo entresacarlo y subrayarlo? Aletea sin contorno con la brusquedad de una aparición, pero después aparece como un pie de estalactitas en las mismas profundidades del infierno" (LEZAMA, 1994, p. 69).

La idea de las correspondencias de Baudelaire subyace en este fragmento donde "les parfums, les couleurs et les sons se répondent”, junto con una imagen donde se contraponen el incesante movimiento y cambio ("aletea sin contorno") y lo inmóvil ("un pie de estalactitas").

\footnotetext{
23 “Le beau est fait d'un élément éternel, invariable, dont la quantité est excessivement difficile à determiner, et d'un élément relatif, circonstanciel, qui será, si l'on veut, tour à tour ou tout ensemble, l'époque, la mode, la morale, la passion. Sans ce second élément, qui est comme l'enveloppe amusante, titillante, apéritive, du divin gâteau, le premier élément serait indigestible, inappréciable, non adapté et non approprié à la nature humane. Je défie qu'on découvre un échantillon quelconque de beauté qui ne contienne pas ces deux éléments" (BAUDELAIRE, 1992, p. 345).
} 
El diálogo con Baudelaire aparece nuevamente como uno de los pilares del ensayo, tanto de forma explícita, como de forma implícita, aunque unas frases más adelante se perciba un movimiento más allá del realizado por el poeta francés a la hora de relacionar la poesía con la pintura.

Para Lezama es "la palabra poética la que ordena las condensaciones que diferencian la igual sutileza de un aire semejante" (p. 69). La metáfora y, en consecuencia, la imagen poética con su poder de hablar de una cosa en términos de otra se convierten en el verdadero vínculo entre dos artes en apariencia diferentes. A partir de esas líneas del ensayo la argumentación y la forma de construir la historia de ambas manifestaciones pasa necesariamente por estas dos figuras. Inclusive, todavía en el preámbulo, Lezama compara unos versos de "Los faros" de Baudelaire, a propósito de Goya, con la analogía de la poesía de Keats con un melocotón hecha por Charles de Bos. La comparación es curiosa, pero deja entrever el peso y la omnipresencia que él le concederá a esta figura retórica a lo largo del ensayo. En este sentido, Lezama Lima es coherente y mantiene su percepción acerca del conocimiento (si lo hay) y su modo de formularlo. Para él no existe como tal una labor de definición o la elaboración de una teoría en términos de pura objetividad sino el oscilar de un péndulo entre una idea y una imagen proveniente de su lenguaje poético o de un cuerpo de ideas como Las eras imaginarias. Vale la pena recordar que su escritura ensayística evita ese segundo modo de esta forma textual que la aproxima al conocimiento científico y que sus famosas frases "toda definición es un conjuro negativo" o "definir es cenizar" (Interrogando a Lezama Lima, 1971, p. 47) son caracterizaciones importantes no exentas de inconvenientes. Si este autor tan sólo sugiere, la aparente ausencia de una argumentación que apunte a una conceptualización sólida evidencia una dificultad si se pretende saber quiénes eran los personajes y las corrientes estéticas en las cuales se insertan. Por esta razón, en las próximas páginas deslindaremos algunas de las temáticas que permiten una aproximación a su modo de escritura y a su concepción de la historia.

\subsubsection{Metáfora}

Dos elementos fundamentales se ofrecen a la hora de establecer una estructura del ensayo "Paralelos...": la metáfora y las eras imaginarias. La originalidad de la propuesta lezamiana reside en una concepción múltiple de esta figura literaria y en un pensamiento donde la imaginación vence una forma causal de razonamiento. Estas ideas se perciben claramente en 
su ensayo histórico "Paralelos..." con la misma fuerza que en aquellos sobre poesía o donde postula su "sistema poético del mundo". Es la metáfora como elemento "vivo", creador de nuevos sentidos, la que podrá vincularse con la memoria, con la Mnemósine mencionada por Lezama y que permite la escritura de la historia. Otro será el caso de las eras imaginarias, donde los planteamientos de ciertas culturas antiguas se cristalizan creando imágenes imperecederas.

Entre las perspectivas sobre la metáfora, queremos destacar tres: la de Paul Ricoeur en La metáfora viva, la de Sarduy en Escrito sobre un cuerpo y la de Cynthia Ozyck presente en un breve ensayo titulado "Metáfora y memoria". Cabe destacar que de los tres, Sarduy es el único que se refiere directamente a la escritura lezamiana, mientras que Ricoeur y Ozyck observan las características determinantes de esta figura. Por lo tanto, un seguimiento adecuado a estas tres perspectivas nos permitirá entender desde diversos ángulos la estrategia poética de "Paralelos...".

Cuatro ideas de La metáfora viva son fundamentales para entender el carácter de este tropo. La primera se relaciona con el romanticismo y la afirmación de Shelley sobre el lenguaje en general como "vitalmente metafórico" (RICOEUR, 1980, p. 90); la segunda es la idea de transacción contextual, en la cual se daría una relación entre pensamientos (p. 116); la tercera refiere el carácter cognoscitivo de la metáfora "que informa y aclara como ninguna paráfrasis podría hacerlo" (p. 125); y, la última, la "metáfora viva", pues como palabra no está limitada al diccionario y crea una nueva connotación o sentido (p. 139).

Más allá del anterior listado, existe también una noción acerca de la "otredad" que representa esta figura y es la unión entre un elemento que se mantiene en la "isotopía" del "contexto y uno ajeno a él, creador de imagen" (p. 249). Este componente "otro" instaura un sentido no contemplado anteriormente y simboliza el poder cognoscitivo asignado al lenguaje metafórico de índole poética. Una “otredad” propia de la metáfora, que muestra la principal diferencia con la mera analogía o comparación. Esta última preservada en el terreno isotópico.

El carácter de la metáfora creadora que genera imagen y que posee una facultad de conocimiento remite a la poesía como forma de pensamiento primitivo que se resiste a un lenguaje conceptual y abstracto propio de las ciencias. Como señala Frye, "la poesía habla el lenguaje del mito, y no el de la razón o el dato; es más, representa un aspecto primitivo de la sociedad y no algo que vaya mejorando o refinándose de modo progresivo" (FRYE, 1986, p.75). Un aspecto inherente al pensamiento lezamiano y que se vincula con lo que podríamos 
denominar un "causalismo mágico" o una nueva forma de conocimiento basada en la imaginación, cuyo instrumento, la metáfora-imagen, se contrapone al causalismo de matriz aristotélica. La ruptura con este último se evidencia, por ejemplo, en textos como "Sobre poesía" de Imagen y posibilidad (escrito en 1968), donde se indica la "eliminación de todo dualismo, de la causalidad, de las diecisiete categorías kantianas y de lo condicionado kantiano" (LEZAMA, 1981, p. 130).

Las relaciones insospechadas, el diálogo entre un elemento que pertenece al contexto y otro que no, la noción de un causalismo mágico fundante de una segunda realidad que confunde porque no tiene relación con la primera, son las características de la escritura lezamiana. Se trata de la dispersión, como reza el título del ensayo de Sarduy sobre Lezama, de "la voraz captación de la imagen [que] opera por duplicación, por espejeo" (SARDUY, 1969, p.62). Adjetivos como "devorador" y "voraz"24, que aluden a la continua capacidad de la metáfora lezamiana de ingerir la realidad, la presencia dialógica entre planos diferentes mediante el espejeo, la alusión a ese doble como el que toma el primer plano y lo mina con su imitación y parodia hasta reemplazarlo, la importancia de la forma que subyuga al contenido mediante el peso de la fonética y, por último, una curiosa idea de fijación: el mundo verbal de estalactita del cubano. Una reflexión pendular sobre Lezama que nos llama la atención por la acumulación, por el doble que devora al original en una imagen de continuidad (en la marcha metafórica los otros dobles siguen devorando), pero también por la inmovilidad, "la petrificación", la "geología verbal" (p. 66). La metáfora ha avanzado, ha devorado, ha ido más allá del original y se ha detenido: ha creado una imagen estática.

Ahora bien, puede establecerse otra concepción sobre la metáfora a partir de su relación con la memoria. Para Cynthia Ozyck, en su corto ensayo "Metáfora y memoria", la primera interpreta a la segunda, pues esta última representa en sí ya algo conocido o experimentado que sugiere o que permite el tránsito hacia lo desconocido. El ejemplo de esta ensayista y novelista es el pueblo judío, que usa su memoria y su experiencia común en la esclavitud para crear algo nuevo: el precepto moral de amar al extranjero. Una memoria que, de acuerdo a

\footnotetext{
${ }^{24}$ Varios críticos han señalado la importancia del "comer" o, en palabras de Lezama, el acto de "incorporar". Uno de ellos es Roberto González Echevarría, quien percibe en la comida ofrecida por Doña Augusta en Paradiso una metáfora del "proceso metabólico de absorción de la patria". Una escena que en la novela resulta representativa porque augura la muerte del tío Alberto. ("La fiesta en Lezama". Disponible en http://www.letraslibres.com/revista/libros/la-fiesta-en-lezama). En el caso del texto de Sarduy, nos llama la atención la idea misma de "devorar" la realidad porque excede la simple idea de ingesta llevándola al terreno del ansia, del tragar apresuradamente, de la avidez. Así, la metáfora "engulle" un pedazo o un trozo determinado de la realidad y devuelve algo nuevo.
} 
esta escritora, no pudo crear el mundo griego con la inmediatez y la espontaneidad de la inspiración, o los romanos con su abierta hostilidad al extranjero. Memoria contra inspiración, en la que la primera puede crear un legado, mientras la segunda permanece en lo inmediato. En suma, una reflexión sobre la "alteridad", sobre la "extranjería", en la que el "otro" pierde su extrañeza y se vuelve familiar, lo que haría cualquier metáfora.

Podemos pensar ahora cómo la reflexión de Ozyck se relaciona con "Paralelos..." o con otros textos de Lezama. Más allá del vínculo evidente con una noción de comunidad -los judíos, el pueblo cubano-, resulta claro que este autor busca convertir o reducir esas otras culturas extranjeras y sus características más notables y perdurables en elementos que construyan una imagen de lo cubano. Sobresale así en "Paralelos..." la mención frecuente a la era imaginaria china con su alquimia y sus metamorfosis: "se trata siempre de reemplazar en la cinta de las metamorfosis, de los cinco colores derivados del pájaro escarlata, que ondulan y gimen al fuego, por una visión placentera" (LEZAMA, 1994, p.100). Las metamorfosis a la que se refiere Lezama en otra ocasión (al comienzo del ensayo) son las de un pájaro escarlata, cuyas mutaciones producen los distintos colores que se fragmentan en estalactitas. Nuevamente vemos los opuestos, mutación e inmovilidad, que se resuelven esta vez en la imagen de Julián del Casal, quien debe reunir la imagen de las estampas asiáticas que quiere coleccionar con elementos de la cultura autóctona: la pintura de Manuel Justo de Rubalcava y los poemas de Joaquín Lorenzo Luaces.

Una última perspectiva de la relación metáfora-memoria aparece en la novela inconclusa Oppiano Licario. De la mano del diccionario de Iván González Cruz, recordamos que es en esta obra donde realmente se menciona la Súmula, nunca infusa, de excepciones morfológicas, una obra insinuada en el capítulo final de Paradiso y que representa la herencia de Licario para José Cemí. Este hallazgo resulta llamativo por varias razones. La primera porque se trata de un texto que nunca aparece publicado en la obra lezamiana, ya que es el mismo González Cruz quien lo recupera en su versión manuscrita y lo publica en el libro Archivo de José Lezama Lima. Miscélanea; la segunda por su carácter poético, pues es una variante que incluye versos de dos poemas diferentes ya editados por Lezama; y la tercera, la más importante, por su carácter simbólico como metáfora de la historia de Cuba. Con respecto a este último rasgo, resulta fundamental señalar que en Oppiano Licario, la Súmula se pierde gracias a un ras de mar o inundación, de la misma forma que en el ensayo "Paralelos..." se menciona la pérdida de un baúl con los escritos de Martí. 
Lo mismo perdemos un anillo hecho por Darío Romano, nuestro primer platero en el siglo XVI, que se inutiliza por la humedad un baúl lleno de la letra de José Martí en el anteayer que viene sobre nosotros como una avalancha. Pero quien poseía ese baúl olvidó una primera regla de conducta, es decir, que el poseedor de un baúl lleno de los escritos de Martí, entre las furias de un huracán o de un terremoto, está en la obligación de salvarlo antes que salvar su vida" (LEZAMA, 1994. p. 78).

Es verdad que la metáfora como ese diálogo con la otredad, con la extrañeza, se construye sobre un fundamento conocido, sobre la memoria, como diría Ozyck. Ahora, si esa memoria no existe, si muchos elementos de la tradición se han perdido, resta la creación mediante la ficción y la inclusión, como en toda metáfora, de un elemento otro, las eras imaginarias, para crear un sentido nuevo: una historia artística y poética cubana. Para ello, Lezama Lima recurrirá a estrategias como la yuxtaposición y el juego con un espesor literario que pone en jaque una noción de verosimilitud exigida en el discurso histórico. No se puede perder de vista que en la escritura de Lezama la presencia constante de la metáfora desproporciona lo ya conocido con nuevas significaciones. En cuanto a la yuxtaposición, estamos de acuerdo con Sarduy cuando señala en Escrito sobre un cuerpo que lo cubano no se construye por asimilación o síntesis y sí por una superposición (SARDUY, 1969, p. 68-69), donde los diferentes planos incluyen también otras culturas.

\subsubsection{Carencia}

Una situación presente en el comienzo del ensayo es la de la carencia como marca de lo cubano. Así:

Entre nosotros es casi imposible configurar una tesis o un punto de vista aproximativo sobre nuestro pasado, ya de poesía, ya de pintura, porque los diversos elementos larvales aún no se han escudriñado, ni siquiera señalado su regirar ectoplasmático [...]. Pero aún hay más, en esos dos siglos tan sólo no existe lo configurativo operante, ni siquiera lo larval llega a su etapa formal, en el sentido escolástico de etapa última de la materia, a la materia que se remansa por una extensión de su materia (LEZAMA, 1994, p.71).

La carencia, la falta que se hace visible en las primeras líneas del ensayo, señala la incapacidad americana para elaborar correspondencias entre las artes porque no hemos llegado a una plenitud en nuestra expresión (p.67), pero también justifica una escritura particular de la historia. Una escritura que, como se verá, involucra una mayor cantidad de referencias al imaginario y a otras culturas que a una cantidad considerable de pintores, escultores o poetas. Una falta que fundamenta una apetencia y una asimilación nunca inocente de la cultura 
universal y con ella una tentativa de fuga frente a la condición periférica del subcontinente hispanoamericano y de Cuba.

Ahora, si la ausencia de una forma artística "acabada" en los siglos "XVII" y "XVIII" es un rasgo cubano y latinoamericano que lleva a la expresión, en el caso de Lezama, de una vasta erudición y de una cultura desbordante que no solamente incluye la tradición occidental, quizás merezca atención la forma como el autor concibe la práctica del consumo cultural. Más allá de la idea de vacío que debe llenarse y la tradición con la cual debería realizarse esta operación, el interrogante puede dirigirse, más bien, a cómo Lezama concibe la naturaleza y la cultura.

Gustavo Pellón, en su libro La visión jubilosa de José Lezama Lima, señala que la actitud de Lezama frente a la naturaleza no incluye una percepción de antagonismo -como en $\mathrm{La}$ vorágine - o una concepción como "lo real maravilloso" de Carpentier. Se trata, más bien, de una entidad que, como la cultura, puede traducirse en imágenes. De hecho, la naturaleza debe ser creada o transformarse mediante el arte, gracias a la intervención de la imagen poética (PELLÓN, 2005, p. 64-66). La obra lezamiana ilustra estas observaciones con un fragmento de La expresión americana (“Mitos y cansancio clásico”), citado por este crítico. Determinada masa de entidades naturales o culturales adquieren en un
súbito, inmensas resonancias. Entidades como las expresiones, fábulas
milesias o ruinas de Pérgamo, adquieren en un espacio contrapunteado por la
imago y el sujeto metafórico, nueva vida, como la planta o el espacio
dominado. De ese espacio contrapunteado depende la metamorfosis de una
entidad natural en cultural imaginaria. Si digo piedra, estamos en los
dominios de una entidad natural, pero si digo piedra donde lloró Mario en las
ruinas de Cartago, constituimos una entidad cultural de sólida gravitación
(LEZAMA, 2001, p. 66).

El pensamiento de este autor está orientado también por el catolicismo y la idea de caída por el pecado original. Por eso, podemos leer en su ensayo "Pascal y la poesía" que "hay inclusive como la obligación de devolver la naturaleza perdida. De fabricar naturaleza, no de recibirla como algo dado" (LEZAMA, 1977, p. 564). La naturaleza es fabricada por la labor creativa del hombre (del poeta) convirtiéndola en una entidad cultural, pero si la naturaleza no existe realmente per se y todo puede ser cultura, ¿cómo se concibe esta última desde el pensamiento lezamiano? Entra en perspectiva una idea de Pellón que continúa un planteamiento formulado anteriormente sobre la causalidad lógica a la que se opone Lezama. Escribe Pellón: 
[...] la cultura para Lezama es tanto algo dado como lo es la naturaleza para la mayoría de nosotros, y esta actitud explica justamente tanto su concepción de la influencia literaria como lo que aparenta ser su absoluta falta de angustia en lo que respecta a la influencia (PELLÓN, 2005, p. 67).

Si la cultura está dada, se comprende con mayor claridad la perspectiva de Cortázar cuando menciona el júbilo con el cual Lezama asume una tradición universal sin ninguna preocupación, sin asumirse él mismo como deudor. La famosa frase de su texto "Entre tanto Lezama en su isla amanece con una alegría de preadamita [...] y no se siente culpable de ninguna tradición directa" (CORTÁZAR, 1970, p. 152) se contrapone al peso de la herencia literaria con el que los escritores europeos se enfrentan. El peso de un fardo caracterizado por algunos "pesimistas" como Eliot, a quien Lezama en "Mitos y cansancio clásico" lanza una crítica que consideramos injusta: "Por eso, su crítica es esencialmente pesimista o crepuscular, pues él cree que los maestros antiguos no pueden ser sobrepasados, quedando tan sólo la fruición de repetir, tal vez con nuevo acento" (LEZAMA, 2001, p. 58). El "cansancio clásico" como parte del título se refiere a este tipo de autores desmoralizados que consideran que no es posible realizar ya ninguna innovación. Frente a esta negatividad, Lezama opone la renovación: "Todo tendrá que ser reconstruido, invencionado de nuevo, y los viejos mitos, al reaparecer de nuevo, nos ofrecerán sus conjuros y sus enigmas con un rostro desconocido" (p. 58). Esta es una de las caras de ese júbilo, una de las facetas en las que se apoya Gustavo Pellón para pensar su "visión jubilosa". Una alegría del pensamiento lezamiano en la que la carencia no es necesariamente negativa: es solamente el vacío que permite la creación por la ficción.

\subsubsection{La expresión americana y Las eras imaginarias: la ficción de la historia}

En "Paralelos..." Lezama hace alusión en repetidas ocasiones a una original concepción de la historia que tiene como matriz generadora a la imagen. Esta novedosa forma de concebirla, en la que no se obedece a una concepción lineal marcada por la existencia de un material empírico, descrito en términos de escuelas, corrientes y artistas, tiene su origen en los ensayos sobre Las eras imaginarias (publicado en 1971) y en La expresión americana (1957). En este último texto, Lezama afirma:

Nuestro método quisiera más acercarse a esa técnica de la ficción, preconizada por Curtius, que al método mítico-crítico de Eliot. [...]. La ficción de los mitos son nuevos mitos, con nuevos cansancios y terrores. 
Para ello hay que desviar el énfasis puesto por la historiografía contemporánea en las culturas para ponerlo en las eras imaginarias. Así como se han establecido por Toynbee veinte y un tipos de culturas, establecer las diversas eras donde la imago se impuso como historia. Es decir, la imaginación etrusca, la carolingia, la bretona, etc., donde el hecho, al surgir sobre el tapiz de una era imaginaria, cobró su realidad y su gravitación. Si una cultura no logra crear un tipo de imaginación, si eso fuera posible, en cuanto sufriese el acarreo cuantitativo de los milenios sería toscamente indescifrable.

Sobre ese hilado que le presta la imagen a la historia, depende la verdadera realidad de un hecho o su indiferencia e inexistencia (LEZAMA, 2001, p. 58-59).

En "Paralelos..." esta imago que se impone a la historia aparece sobre todo con las menciones a los chinos. Sobresale, sobre todo, la referencia al esoterismo de esta cultura: la alquimia. En un pasaje donde claramente se aprecia esta transformación de una "entidad natural" a una "entidad cultural", Lezama menciona el pájaro escarlata de los cinco colores como la metáfora del cinabrio o de la sangre. Con Hernando de la Parra y Juan Maldonado la metáfora se acerca a la pintura, a los dos hombres como los donceles de un tapiz de Zamora [figura 1].

No obstante, la columna vertebral para comprender esta visión de la historia se relaciona con la ficción. No por el hecho mismo de la carencia como punto de partida sino porque, como el mismo autor admite, no hay vestigios ni poéticos ni pictóricos de muchas obras que se supone fueron creadas u oídas, ya que "casi todo lo hemos perdido, los crucifijos tallados y el cuadro de la Santísima Trinidad, de Manuel del Socorro Rodríguez" (LEZAMA, 1994, p. 78). Y repite todavía con mayor énfasis, a partir de la alabanza a Juana Borrero y sus "Negritos" [figura 5]: "Todo lo hemos perdido, desconocemos qué es lo esencial cubano y vemos lo pasado como quien posee un diente" (p. 79).

La carencia de una tradición ya formada o de obras de artistas representativos de los siglos XVIII y XIX impulsa con más fuerza una escritura de la historia que debe llenar con la imaginación los vacíos dejados por la ausencia. De ahí que Lezama Lima realice la práctica de las falsas citas tan denostada por algunos críticos y comprendida en su dimensión lúdica por sus amigos. Una distorsión que consiste en atribuir citas a personas que no corresponden, a la escritura errada de los nombres, y a la misma creación de las situaciones, de las frases o de los personajes que las inventaron. Nuevamente Margarita Mateo Palmer señala esas situaciones donde el cubano "juega" e "inventa", pues no existe una ausencia de respuesta o una negación 
sino un juego, una continua fabulación, que inclusive está presente desde la conversación cotidiana con el autor cubano ${ }^{25}$.

La invención vista aquí se relaciona con el método de ficción que Lezama Lima preconiza en el fragmento citado de Las eras imaginarias. Para él no se trata de crear un método mítico crítico exactamente como el que propone Eliot en su artículo "Order and myth" (al cual Lezama se refiere) y sí de exceder ese "pesimismo" que restringe el carácter creativo del mito a fórmulas que estructuran las obras literarias consideradas modernas. Para él, el mito respondería a la invención y continuaría configurando las obras, pero sin convertirse en la clave de su comprensión. De ahí que en La expresión americana aquella frase de "nuestro método quisiera más acercarse a esa técnica de la ficción" (LEZAMA, 2001, p.58) sea, posiblemente, la antesala de la reflexión que realizará en los sesenta sobre Las eras imaginarias.

De todas maneras, la presencia de las eras imaginarias en "Paralelos..." permite percibir cómo Lezama realiza una revisión de la historia. La forma como retoma civilizaciones antiguas para destacar la fuerza en que su imaginación crearía metáforas perdurables aumenta la presencia de una escritura poética en el ensayo y, si se quiere, de elementos esotéricos. La idea de crear nuevos mitos o, más bien, de "reconstruirlos", como afirma unas líneas más adelante, informa su propia visión histórica. Una perspectiva muy personal y, como se ha señalado, en pugna con el "estatismo" del código de una literatura "pesimista". Como indicamos cuando mencionamos un "causalismo mágico" en la escritura lezamiana, la resistencia a la definición presente en su famosa frase "definir es cenizar" (Interrogando a Lezama Lima 1971, p. 47) invita a pensar la obra lezamiana desde múltiples miradas.

Si Lezama reinventa mitos y los incorpora a la escritura histórica, ésta agrega una dimensión más a la característica que Hayden White observa como propia de los anales. La historia no incluye únicamente datos, fechas y eventos de forma aislada y como contenido sino que la forma en que es escrita configura un estilo y también obedece a la noción de género literario como convención. Así lo señala el crítico estadounidense en su Trópicos do discurso, cuando afirma que la constitución de una situación histórica es esencialmente una “operación

\footnotetext{
25 Un ejemplo es la presencia en "Paralelos..." de dos figuras cuya verdadera existencia no ha podido establecerse: Rutilio Graco e Ybrovac. Esta práctica de citar personajes y situaciones reales e inventadas en un mismo nivel es señalada por Margarita Mateo Palmer a partir de su lectura de textos de Eliseo Diego y José Agustín Goytisolo. Según esta crítica, Lezama hablaba de todos los temas y "nunca se sabía cuándo terminaba su erudición y cuándo comenzaba a inventar" (PALMER, 2006, p. 24).
} 
literaria", es decir, "creadora de ficción", donde las "estructuras del argumento" equivalen a "una de las maneras de que la cultura dispone para tornar inteligibles tanto el pasado personal como el pasado público" 26 (WHITE, 2001, p.102). En el caso de Lezama la ficción como técnica y estructura inherente al texto histórico es superada y llevada al contenido, de modo que ocasiona que la historia relatada parezca avanzar en forma de espiral y nunca en forma lineal. Avances, retrocesos, repeticiones y saltos existentes gracias a "las eras imaginarias" que propician las volutas, como cuando habla de una obra literaria cubana específica del siglo XIX y a renglón seguido realiza una asociación con los colores de la pintura cubana, con Goethe y con Humboldt. En este sentido, la expresión metafórica gobierna la escritura y una "entidad natural" o una "cultural" se convierte en una fuente para la imagen. De ahí que cualquier persona o cosa pueda ser el emblema que le permite expresar sus creencias poéticas y éticas.

\subsection{UNA ERA IMAGINARIA Y DOS ESTÉTICAS}

Roberto Méndez señala a "Paralelos..." como una propuesta de configuración de una "era imaginaria":

El título del texto hace pensar en una especie de juego exquisito en el que se registran convergencias en el desarrollo del discurso poético y el plástico de la Isla. En realidad, se trata de algo más trascendente: la propuesta de un método para configurar la cultura cubana, desde sus orígenes, como la "era imaginaria" que da cima a su sistema y explica el ser íntimo nacional. En este sentido, el trabajo dialoga con otras obras que Lezama prepara por esa época, en que está empeñado en reinterpretar la cultura cubana, especialmente la del período colonial: su monumental Antología de la poesía cubana (1963), así como la compilación de textos de El Regañón, la poesía de Zenea y las conferencias que lee en el Instituto de Literatura y Lingüística sobre Zequeira, Rubalcava, Heredia, la Avellaneda y otros románticos. (MÉNDEZ)

Una hipótesis bastante interesante y sugestiva, sobre todo, cuando su autor señala que los argumentos son el uso del “"método mítico” por el que abogara en La expresión americana” y la concepción (más allá de las correspondencias baudelerianas) del vínculo entre la poesía y las artes plásticas como vehículos de una “invención” que permite estructurar una "era

\footnotetext{
${ }^{26}$ A continuación citamos la versión en portugués que hemos consultado con el fin de aclarar un poco más esta tesis central acerca de la narrativa histórica. "Trata-se esencialmente de uma operação literária, vale dizer, criadora de ficção. E chama-lá assim não deprecia de forma alguma o status das narrativas históricas como fornecedoras de um tipo de conhecimento" (...) así "estruturas de enredo é uma das maneiras de que a cultura dispõe para tornar inteligíveis tanto o passado pessoal quanto o passado público" (WHITE, 2001, p. 102)
} 
imaginaria”. El ejemplo de este último argumento es la creación del Nuevo Mundo por parte de Colón antes de llegar a él:

Cuando el Almirante va recogiendo su mirada de esos combates de flores, de esas escaleras que aíslan sus blancos como aves emblemáticas, el arquero negro cerca de la blancura que jinetea Tanequilda, y las va dejando caer sobre las tierras que van surgiendo de sus ensoñaciones, se ha verificado la primera gran transposición de arte en el mundo moderno (LEZAMA, 1994, p. 66-67).

La hipótesis de Méndez resulta muy atractiva porque permite recoger algunas observaciones sobre la importancia de la reconstrucción y la invención de nuevos mitos desde la ficción, y a la vez permite instaurar a la imaginación y a la imagen poética en el centro de la reflexión sobre la forma de configuración de "Paralelos...". La idea de poiesis, la creación de nuevos mitos, se convierte en la base de un ensayo que apela a las eras imaginarias como parte de su contenido y que ambiciona constituirse como una de ellas, si se sigue la idea de este crítico. Una manifestación mítica de la cultura de la isla que, perdurable en el tiempo, surge a partir del fragmento, del vacío, y no de una expresión cultural acabada. Si recordamos las palabras del autor de Paradiso, vemos la magnitud de la carencia como una condición sine qua non de esta memoria metafórica, de esta de construcción histórica que describe el desplazamiento de la elipsis, de forma que:

Paradójicamente, con mucha abundancia de luz tendemos a la pérdida de lo esencial. La sacralidad de lo que es verdaderamente importante se nos escapa en vida, se desconoce después de la muerte y cuando abrimos los ojos ya nos vemos obligados a reconstruir, pero de la misma manera que la intuición no puede actuar sobre los jardines de Saturno, la imagen se atemoriza ante lo perdido, porque comienza a describir enloquecidos movimientos elípticos, no sobre el vacío engendrado por la pérdida, sino sobre el encuentro, pues actúa pensando no sobre el tesoro perdido en Esmirna, sino sobre lo perdido en Esmirna que se encontró en Damasco (LEZAMA, 1994, p. 77-78).

A partir de los vacíos en la configuración de la tradición artística y literaria cubana surge otra importante característica en la estructura de "Paralelos...": una estética de la resonancia y una de la sustitución. La primera se observa constantemente en toda la obra lezamiana y responde a la percepción del escritor cubano sobre la tradición; la segunda no es una constante en todo el ensayo objeto de nuestro estudio, pero representa sus dos momentos culminantes: el lienzo "La siesta" de Guillermo Collazo [figura 4], visto a través de Julián del Casal, y la 
relación entre el cuadro "Los negritos" frase citada sobre lo perdido en Damasco, pero encontrado en Esmirna, la sustitución es un paso más allá de la retórica sobre las correspondencias y figura también en la ecfrasis o la sugerencia de imágenes plásticas a través de la descripción literaria.

\subsubsection{La estética de las resonancias}

En el ensayo "Julián del Casal", publicado en Analecta del reloj, Lezama señala el carácter del "razonamiento reminiscente", una propuesta de práctica crítica mostrada por el cubano que se centraría en la labor de la "memoria" y en los "ecos" que un autor tiene al respecto de la obra de otro. Una característica de la labor del poeta-crítico que, como señala Enrico Mario Santí, no "es ningún descubrimiento espectacular para nosotros pero, en su momento, es una declaración lo suficientemente revolucionaria para que sea ignorada por completo" y que "supone precisar la función del enlace intertextual” (SANTÍ, 1975, p. 539). En palabras del poeta:

Ese razonamiento reminiscente, puede evitarnos que la crítica se acoja a un desteñido complejo inferior, que se derivaría de meras derivaciones, influencias o prioridades, convirtiendo miserablemente a los epígonos americanos, en meros testimonios de ajenos nacimientos. Ese procedimiento puede habitar un detalle, convirtiéndolo por la fuerza de su mismo aislamiento, en una esencia vigorosa y extraña; no detenerse en los groseros razonamientos engendrados por un texto ligado a un texto anterior, sino aproximándose al instrumento verbal en su forma más contrapuntística, encontrar la huella de su diferenciación, dándole más importancia que a la influencia enviada por el texto anterior al punto de apoyo, rápido y momentáneo, en el que se descargaba plenamente. Así por ese olvido de estampas esenciales, hemos caído en lo cuantitativo de las influencias, superficial delicia de nuestros críticos, que prescinden del misterio del eco (LEZAMA, 1977, p. 70).

\footnotetext{
27 Según Roberto Méndez, el lienzo "La siesta” de Guillermo Collazo (1850-1896) es una de las imágenes paradigmáticas de la Isla. En él aparece una mujer recostada en un sillón con el jardín y el paisaje insular de fondo (Collazo, el pintor de la siesta. Disponible en: http://www.habanaradio.cu/singlefile/?secc=13\&subsecc=117\&id_art=20091106170202. Consultada en: 9 nov. 2012). En cuanto a "Los negritos", de la pintora y poetisa Juana Borrero (1877-1896), se trata de un cuadro expuesto en el Museo de Bellas Artes de Cuba, cuyo título original es "Pilluelos". Fue pintado en 1896 en Cayo Hueso y es el último lienzo de la pintora.

${ }^{28}$ La sustitución es una de las características que Sarduy percibe dentro del artificio barroco, aunque la restrinja más que todo a objetos y no a referencias culturales. Es lo que sucede, por ejemplo, en el ensayo "El barroco y el neobarroco" de América Latina en su literatura cuando, al enunciar este aspecto, menciona el cambio en Paradiso del miembro viril por "el aguijón del leptosomático macrogenitoma". Otro aspecto que también aparece en este mismo texto es la densidad de la intertextualidad, una dimensión relacionada con la estética de la resonancia (SARDUY, 1972, p. 169-170).
} 
Lezama aboga por una forma de lectura crítica de la tradición que se detenga en una intertextualidad vista desde el "eco", desde la frase "entreoída" (PELLÓN, 2005, p.70) y no tanto en la determinación de fuentes concretas en una obra determinada. Este trabajo, propio de la forma tradicional de la crítica, lleva a un inventario que reforzaría una idea de copia. Frente a ella, Lezama opone una concepción del poeta-crítico, donde esta crisis de lectura o de práctica tradicional de la misma se resuelve mediante un ejercicio de "reminiscencia creadora”, en la que el diálogo con la tradición se da en la memoria del lector-autor. Más que ver relaciones causales, el poeta-crítico lee un texto desde una relación de intertextualidad que no se asemeja de ningún modo a una relación causa-efecto sino a una complicada red de vínculos. A partir de estas ideas, comprendemos a Gustavo Pellón cuando, al leer a Lezama, insiste en la inversión de la relación "causa-efecto" como la "respuesta iconoclasta preferida de Lezama" (p. 71) y la predilección del poeta cubano por otros métodos más vinculados a las "resonancias" o, mejor aún, a las "iluminaciones". Así lo argumenta cuando recurre a un texto del poeta publicado en el Centro de Investigaciones Literarias de la Casa de las Américas.

Las influencias no son de causas que engendran efectos, sino de efectos que iluminan causas. Proust hace que se lean las memorias de Saint-Simon o que se vuelva al sentido del relato de Las mil y una noches, como una consecuencia de una acto excepcional, pero desgraciadamente los profesores, que son los gendarmes obligados de estos temas, gustan más de las cadenas causales que de las iluminaciones. La impregnación, la conjugación, la genminaridad son formas de creación más sutiles que los desarrollos causales ${ }^{29}$ (PELLÓN, 2005, p. 71).

La "impregnación, "la conjugación", "la genminaridad" son formas relacionadas con las "iluminaciones", con las "resonancias" que el poeta cubano propone como formas de comprensión y lectura de los textos literarios, pero también hacen parte de su propia práctica y concepción del lazo con la tradición literaria. De ahí que pueda pensarse con Gustavo Pellón en otra práctica: la de la yuxtaposición.

Como lector, escritor y ensayista, Lezama emplea la misma técnica básica: la yuxtaposición (quizá lo que él llamaría "conjugación”, activando el sentido etimológico de la palabra: juntados por el yugo). Con la yuxtaposición de elementos inesperados (la imaginería en su poesía, las obras literarias en sus ensayos y novelas) Lezama espera provocar la chispa de la revelación. [...]

\footnotetext{
${ }^{29}$ Habría una clara convergencia entre esta idea de Lezama y el ensayo "Kafka y sus precursores" (1952) de Borges, un texto influenciado por Tradición y talento individual de T. S. Eliot (1920). En este escrito, el autor argentino propone que cada autor al escribir crea sus propios antecesores dentro de la tradición literaria. Como en la propuesta de Lezama, no se trata de una relación directa de causa-efecto, sino un vínculo absolutamente variable y dinámico como lo muestra el hecho de que entre esos precursores kafkianos esté Zenón, Han Yu, Kierkegaard, Browning, Leon Bloy y Lord Dunsany.
} 
Lezama, anticipándose a la resistencia, defiende su método del cargo de ser caprichoso en su ensayo "A partir de la poesía" (PELLÓN, 2005, p. 73).

Las frecuentes asociaciones, los aparentes saltos donde Lezama invoca un dato, a una figura que no parece directamente involucrada con la argumentación, señalan su reticencia hacia una forma exhaustiva en la investigación, hacia una argumentación que busca aproximarse a una verdad, a la postulación de una teoría. Su práctica escrituraria ejemplifica esa "razón reminiscente" en la que el recuerdo es el centro estructurador, el lugar del diálogo entre las infinitas lecturas y sus relaciones intertextuales. De ahí que sean su memoria y su vasta erudición las que se plasmen continuamente en sus ensayos mediante citas, personajes y situaciones que muchas veces se alejan del tema planteado originalmente y llegan a rozar temáticas dispares ${ }^{30}$.

Otra situación mencionada anteriormente y que acompaña su escritura es la expresión metafórica. Así, por ejemplo, en "Paralelos...", al referirse a la obra de Joaquín José García, afirma: "En sus páginas, más hundidas que sencillas, agrandadas por la imago actuante con bigotes de lince, se atreve con el corralón para comicuchos, entreabriendo una barraca cerca del castillo de la Fuerza" (LEZAMA, 1994, p. 72). Una primera caracterización que no está expresada en un lenguaje sencillo, pero sí con la fuerza asociativa de la metáfora. No obstante, otras asociaciones o resonancias aparecen a lo largo del texto y en repetidas ocasiones. Es el caso de Rutilio Graco “propietario de la pobreza, del gusto, de los delirios poéticos y del cientificismo. Sus biógrafos afirman que lo que escribía tenía la locura que excita la risa y el genio que doblega la admiración" (p. 75); un romano que en apariencia no tiene relación alguna con la imagen que dibuja para su lector sobre la obra de García.

\footnotetext{
${ }^{30}$ Esta práctica escrituraria sería propia del ensayo literario. Al respecto nos gustaría mencionar un texto de Eduardo Grüner sobre este género como lectura de un "acto fallido", del error al que todo escritor está atado. En palabras de este crítico argentino, la diferencia entre la ciencia literaria y el ensayo radica en "que no se propone, al menos a priori, restituir ningún origen -ni el Autor, ni el Código, ni el Sentido-ni tampoco anticipar ningún Destino, sino constituirse como testimonio de ese acontecimiento por medio de la escritura" (GRÜNER, E. "El ensayo, un género culpable". Revista Sitio, Buenos Aires, No. 4/5, p. 53, 1985). No habría así una obligación metódica ni una voluntad de explicación sobre el autor, la forma o el contenido de una obra, sino un desvelamiento acerca de la particularidad (caracterizada como "error") de un texto. Desde esta perspectiva, la escritura ensayística sería libre en la forma como lee esa falla originaria, es decir, no está sujeta a un orden estricto en la exposición y en la argumentación. Recordemos también a Giordano cuando subraya que el ensayista literario favorece la forma sobre el contenido.
} 


\section{4 "PARALELOS...": UNA RELACIÓN DE INTERPRETACIÓN ENTRE LA LITERATURA Y LA PINTURA}

Una característica fundamental del ensayo "Paralelos..." es la relación entre los sistemas plástico y literario, y la forma como uno interpreta al otro y viceversa. Una particularidad que es percibida desde su inicio con la ecfrasis ya señalada, pero que continúa y se repite varias veces. Es lo que sucede cuando al terminar la introducción (donde han sido incluidas las eras imaginarias y se advierte la situación de carencia), Lezama introduce una imagen plástica estática que es reinterpretada y transformada, por la intervención de lo literario, en una imagen dinámica:

Como los donceles que exornan las tapicerías de Zamora, sale de noche Hernando de la Parra, de la servidumbre del gobernador Juan Maldonado. Sale a sus correrías por barracas de cómicos, por extravagancias de bailetes nocherniegos, donde el crótalo y el calabazo arañado sincopan la sangre. Pero ese Hernandillo es tan sólo un títere aleteante, con pausas ahogadas, movido por un vejete burlón que sopla el polvo y estornuda por la galería de la Sociedad Económica de Amigos del País (LEZAMA, 1994, p. 71-72).

A la luz de "Mitos y cansancio clásico", esta imagen pictórica y su posterior metamorfosis en una imagen con movimiento se produce por la intervención de un sujeto metafórico:

Lo que ha impulsado esas entidades, ya naturales o imaginarias, es la intervención del sujeto metafórico, que por su fuerza revulsiva, puso todo el lienzo en marcha, pues, en realidad, el sujeto metafórico actúa para producir la metamorfosis hacia la nueva visión [...]. Pudiéramos tal vez decir que ese sujeto metafórico actúa como el factor temporal, que impide que las entidades naturales o culturales imaginarias se queden gelée en su estéril llanura (LEZAMA, 2001, p. 53-54).

Así, no se trata simplemente de ver los tapices de Zamora [figura 1] de forma aislada con respecto a la historia de Hernando de la Parra (contenida en la obra de Joaquín José García, Protocolo de antigüedades) sino en percibir cómo la narración sobre el conquistador presente en Cuba aspira en la escritura lezamiana a asemejarse o a ser interpretada como una era imaginaria a través de la comparación con los tapices. Esta posible hipótesis surge en la medida en que son comparadas una era imaginaria existente en los tapices de Zamora con una 
reconstrucción histórica que apela más a la imaginación que al documento histórico ${ }^{31}$. Vale la pena recordar que una era imaginaria no es necesariamente una cultura y, que, por lo tanto, la tesis de Méndez sobre "Paralelos..." como la ambición lezamiana de crear una era imaginaria, recibe con este argumento un mayor soporte.

No basta que la imagen actúe sobre lo temporal histórico, para que se engendre una era imaginaria, es decir, para que el reino poético se instaure. $\mathrm{Ni}$ es tan sólo que la causalidad metafórica llegue a hacerse viviente, por personas donde la fabulación unió lo real con lo invisible como los reyes pastores o sagrados, el Monarca como encarnación viviente del Uno (que en la cultura china arcaica es el agua, el norte y el color negro), o un Julio César, un Eduardo el Confesor, un San Luis, o un Alfonso X el Sabio, sino que esas eras imaginarias tienen que surgir en grandes fondos temporales, ya milenios, ya situaciones excepcionales, que se hacen arquetípicas, que se congelan, donde la imagen las puede apresar al repetirse. En los milenios, dirigidos por una cultura, donde la imagen actúa sobre determinadas circunstancias excepcionales, al convertirse el hecho en una viviente causalidad metafórica, es donde se sitúan esas eras imaginarias (LEZAMA, 1982, p. 44).

En el caso de una cultura que cristaliza como era imaginaria puede hablarse temporalmente de milenios, pero cuando no se trata de espacios temporales tan grandes, una situación "excepcional" o "arquetípica" es suficiente. Las situaciones "arquetípicas" o los personajes "excepcionales" serían los que posibilitan una era imaginaria cubana. La figura de Martí ejemplifica esta última aseveración. Después de describir eras como la filogeneratriz (idumeos, escitas, chichimecas), la egipcia (en su elemento tanático), la órfica y la etrusca, la de los "reyes como metáfora" y la china, toma al "Apóstol" como el modelo de la "posibilidad infinita". Una figura "modelo" o "arquetípica" de la pobreza sobreabundante, del hombre de armas y letras que ilustra al verdadero ser cubano (LEZAMA, 1982, p. 33-53).

El siguiente y último momento donde se apela a la figura de Hernando de la Parra antecede a la aparición de un personaje romano, del cual no se sabe si fue una invención del poeta cubano o existió en la realidad con otro nombre. Se trata de Rutilio Graco, un personaje extravagante que "siendo flacucho y débil, tuvo la peregrina ocurrencia de disfrazarse de Hércules" (p. 75); y luego de ser liberado de un encierro en la cárcel, crea un triple sombrero. La aparición de este personaje dentro de la órbita de Hernando de la Parra reafirmaría la

\footnotetext{
${ }^{31}$ La "Crónica apócrifa de Hernando de la Parra”, mencionada por García en su Protocolo, ejemplificaría el comienzo de una era imaginaria cubana al ser comparada con los tapices de Zamora, imágenes de los siglos XV y XVI sobre Alejandro, Aníbal y la Guerra de Troya. Para muchos, también esta crónica explica el origen del son cubano, un género musical que comenzaría con la canción de Ma Teodora de las hermanas Ginés. Lezama en "Paralelos..." se refiere a esta canción.
} 
estética de las resonancias, la importancia de la idea de era imaginaria y el peso de una imaginación abarcadora e inclusiva.

\subsection{1 "Paralelos...": poetas, pintores, encuentros y desencuentros}

La primera obra a la que Lezama se refiere en "Paralelos..." es al Protocolo de antigüedades (1845). Su autor, Joaquín José García, es imaginado por el poeta como un "viejecito" que "tiene que ser querido y reverenciado, pues si no lo hacemos parece que nos daría un pellizco en las mejillas" (p. 72). Este primer autor, vinculado con las Crónicas de Indias, surge como alguien que "no se atreve a invencionar un juego poético" (p. 72), pero que "se atreve con el color" ayudado por los cronistas. Este atrevimiento se relacionaría con la descripción misma, un elemento que en García sería errático pues compara cosas que no se pueden comparar. Así, desde la perspectiva del ensayista:

Es casi lo mismo, pero la comparación demostrativa enseña la diferencia, pero para nuestro ingenuo burlón es lo mismo cosas que ni siquiera se pueden comparar por semejanza para encontrar la desemejanza. El cronista capta una nueva naturaleza, pero se confunde en la semejanza de las formas, igual tamaño pero distinto peso, como si con nuevos ojos fabulosos pudiera pesar la fruta contorneada en el nuevo cristal de la brisa que comienza (LEZAMA, 1994, p. 73).

La crítica de Lezama apunta a las falencias en la descripción de la realidad cubana por parte de García. Mientras que un cronista de Indias logra captar la esencia del color del paisaje y de las frutas por comparación con los de Europa, García compara elementos que no se pueden comparar. Perdemos así la cualidad plástica de la descripción, el color, para el caso cubano, pero también se gana un espacio que contribuye a la configuración de una era imaginaria: Ma Teodora y las hermanas Ginés. Una construcción analógica que recuerda a la del mismo poeta, quien compara la serpiente del Ouroboros con la concurrida fiesta de San Juan:

Es un día de San Juan, que el calendario ecuménico señala para que la sangre salte sus dos círculos. Sorpresiva una paradoja muy nuestra: hay alboroto, pero al final los verbeneros quieren que la comedieta vuelva a empezar. En esa suma de gritones, como dentro de la serpiente con la cabeza en la cola, como en el Ouroboros de los egipcios, se señalan con más precisión los cuatro músicos que están rajando la leña de Ma Teodora. La gritería fiestera le ha dado entrada al ritmo. Y aquí el viejito dice verdad, pues lo popular santiaguero lo apuntala y recuerda las dos hermanas negras dominicanas, colocando sus grillos rociados en el traste (LEZAMA, 1994, p. 72). 
La referencia a las hermanas Ginés se relaciona, como se ha mencionado, con el origen del son cubano. Oriundas de Santo Domingo, estas hermanas dominicanas habrían compuesto en 1562 la canción de "Ma Teodora", una pieza que se convertirá en la primera muestra del son. Aunque según algunos autores su existencia es dudosa, otros estudian la posibilidad de que el son no sea cubano sino de origen dominicano. Más allá de la polémica musical sobre la verdadera nacionalidad del popular ritmo, lo que interesa ver aquí es el énfasis lezamiano en la noción de lo cubano y sobre todo en la conformación de una "situación excepcional". En este sentido, y a pesar de que la obra de García no sea vista totalmente de forma positiva por Lezama, este episodio recibe una confirmación en la que no solamente aparece que el “ingenuo burlón” dice una verdad sino que ésta tiene el carácter de una era imaginaria. No es casual, en el fragmento destacado por nosotros, la aparición del Ouroboros, ni mucho menos la comparación: un "como" que vincula la escena de la fiesta y de los músicos tocando "Ma Teodora" con la serpiente propia de la era imaginaria egipcia. Con las hermanas aparece así un primer indicio que busca convertir a los protagonistas de la historia poética y artística cubana de los siglos XVIII y XIX en una era imaginaria.

La descripción del espacio de la isla continúa en términos de color. A propósito de la obra de Joaquín José García, Lezama retoma la incapacidad de este autor para mostrar los verdaderos colores del paisaje cubano.

Habla de un rosado bajo, olvidando que nuestro mejor rosado sale del
caracol y de las agallas, viene de la nutrición soterrada y de los reflejos
marinos. Nuestro amarillo no es el hepático e hispánico, sino da en el escudo
de la refracción y del chisporroteo, y a veces nos recuerda los versos de
Goethe [...]. Nuestro blanco no es una túnica penitencial de Zurbarán [figura
2], sino es el halo contrastado por el color amarillo, es también el cono de
luz en el centro de la ley del torbellino y del dios que huye [...]. El verde
matizado de las hojas se estabiliza en una casaca de Escobar [figura 3] o en
la fronda que rodea una hamaca de Collazo, pero se pierde inutilizado en el
paisaje de cañaverales (LEZAMA, 1994, p. 76-77).

Para Lezama la incompetencia de García para definir el paisaje cubano se relaciona con su falta de imaginación, con que no se atreva a "invencionar un juego poético" (p. 72). Si para el ensayista situaciones o personajes pueden convertirse en una metáfora, en una nueva asociación, García no es capaz de crear metáforas e imágenes que den cuenta del paisaje de la isla. La imaginación como imperativo que Baudelaire reclama para la pintura paisajística, Lezama la solicita para la escritura y la descripción de la realidad cubana. El paisaje debe interpretarse mediante la descripción, mediante el uso de la imaginación y de las metáforas adecuadas. Por ello, al hablar del amarillo apela a las imágenes del chisporroteo y la refracción 
o al poema de Goethe. En suma, así como Baudelaire critica la pintura de paisaje francesa de pintores como Millet o Théodore Rousseau, porque es una copia de la realidad, una fotografía del paisaje que no tiene un ápice de imaginación, Lezama aplica el mismo criterio pero a la escritura que da cuenta del color, del cuadro imaginario de lo que es el paisaje cubano. La relación de interpretación entre ambas artes aparece aquí de modo especular.

Luego de pensar en el paisaje, en su pintura desde la descripción y el empleo de la metáfora, el poeta pasa a otra asociación: la del periodista y poeta Manuel de Socorro Rodríguez (1758-1819) con la artesanía de la época.

Trabaja el artesano una jarra de barro, sopla para pronunciarle el tronco, sumerge en el azar sus dedos para afinarle un cuello de florentina, curva como una congelada cascada la boca silenciosa, pero espera la gravia a que los dones caigan sobre la vigilia y que un día señalado desde lo invisible la boca de la jarra comience a cantar. En ese júbilo Manuel del Socorro Rodríguez escribe sus octavas de Las delicias de España (LEZAMA, 1994, p. 79).

La asociación entre ambas artes es señalada por Lezama también desde las palabras de Rodríguez con respecto a su poema en octavas, Las delicias de España. "Toda la idea del poema, nos dice [Rodríguez], es dar al buril español asunto para una lámina” (p. 79). El buril, instrumento que usan los grabadores, se convierte en la herramienta que grabará una imagen a semejanza de la palabra poética creadora de imagen (o de imágenes). La conciencia del poeta, que desarrolló una intensa actividad periodística en Colombia, es crear una obra-poema que ojalá se convierta en el motivo de una pintura. Su búsqueda no representa una novedad para la época, dada la relación entre la pintura y la poesía, y la existencia misma de poemas ecfrásticos ${ }^{32}$. No obstante, la opinión del ensayista sobre la calidad de Rodríguez deja entrever dudas, pues es un poeta que no ha alcanzado una forma acabada: "la jarra del artesano canta, pero su imposta es todavía demasiado insegura" (p. 79).

Otro de los personajes que desfila por la historia planteada en "Paralelos...” es José Surí y Águila (1696), médico empírico y poeta. “José Surí, en su cazuela de sanguijuelista, que desprecia al protomedicato y prefiere sus oraciones para sacarle los demonios a los cuerpos,

\footnotetext{
${ }^{32}$ La poesía ecfrástica no solamente obedece al precepto horaciano de "ut pictura poiesis" ("como la pintura, la poesía"), sino que, como señala David Huerta, comienza mucho antes de Horacio y su práctica se extiende hasta la actualidad. De este modo, este tipo de poesía, con su habilidad para representar mediante el lenguaje verbal una expresión visual (un cuadro), aparece primero en los versos homéricos dedicados al escudo de Aquiles y continúa con innumerables ejemplos, entre los que Huerta destaca el poema "Este que ves, engaño colorido" de Sor Juana, "A las ruinas de Itálica" de Rodrigo Caro, la égloga III de Garcilaso, "Al triunfo de Judith" de Lope de Vega y, más recientemente, Nadja (la novela surrealista de Bréton), Estampas, Museo, Apolo (teatro pictórico), del poeta Manuel Machado y los poemas de Rafael Alberti. ("La poesía de las imágenes". Revista de la Universidad de México, México D.F., No. 46, p. 103-105, dic.2007).
} 
hierve piedras preciosas extraídas del estuche del lapidario de San Isidoro" (p. 80). El galeno aparece descrito como un alquimista, ya que "su deleite" "son las piedras preciosas para derivar de ellas el calor que la humana combustión necesita" (p. 80). Pero no cualquier piedra se destaca entre toda la enumeración de las gemas de Surí. El jaspe es la piedra que sobresale porque es el color "acariciado por las nudosas manos de Góngora". El color se vuelve aquí el motivo principal que, más allá de lo esotérico, enlaza tanto la efusión colorida de un Surí alquimista, la imagen poética de Góngora con una piedra de color verde asociada a culturas antiguas y la pintura de una mano descomunal con una gran cantidad de anillos de muchos destellos (p. 81).

Otros autores que el poeta menciona son Manuel de Zequeira y Arango y Manuel Justo de Rubalcava. Del primero, poeta, periodista y militar, Lezama señala la primacía del verde y la ausencia de colores intermedios en su poesía; del segundo, poeta y pintor, observará la conjugación de colores (el verde y el morado) que lo aproximan a una idea de voluptuosidad ${ }^{33}$. Pese a que el autor no se demora mucho en el análisis de estos dos poetas, sobresale la idea de que Rubalcava "iguala de forma sorpresiva al artesano con la naturaleza" (p. 84). De alguna forma, Lezama percibe en Rubalcava a alguien que intenta hacer de un producto cultural -el poema- un elemento natural, despojado de artificio.

Otro de los personajes esenciales en la historia cubana es José María Heredia. En las páginas dedicadas a este poeta, el creador de Paradiso menciona la forma como refleja el paisaje, sus poemas amorosos y la fatalidad que marcó su destino. Ha sido un "niño mimado", como lo señala Martí, de acuerdo a Lezama, que vislumbra el paisaje en términos occidentales y que, tras la muerte de su padre, "toca el espíritu de las ruinas" (p. 90). Sin embargo, es este mismo poeta quien permite la comparación con la pintura, al ser también el poeta mayor del romanticismo.

En esos grandes momentos, el romanticismo poético americano, que Heredia representa por entero, nuestra pintura no gana el paisaje todavía, está enredada en mitologías desconchadas, en símbolos de cementerio, en torpes destrezas académicas, sólo logra atraernos a la pintura de una familia

\footnotetext{
${ }^{33}$ Es llamativa la aparición recurrente de los colores a la hora de evaluar la poesía cubana de estos dos siglos. Al respecto podemos pensar en dos situaciones. La primera es la mencionada relación con el modernismo, en la medida en que este movimiento se preocupa, de la mano de Darío, por los aspectos visuales y de color en el poema (una característica plástica que también destaca Leonel Capote en la introducción a la compilación de La visualidad infinita); la segunda, se manifiesta en poemas de Lezama como "Me hace propenso" de su libro Fragmentos a su imán. En este poema, el cubano destaca los colores blanco y verde, junto con la idea de que cualquier objeto puede evocar otro por el color: "La túnica del dominico de verba derramada / se pinta con el barniz innato / del blanco del espárrago. / En la mañana tropezando con la blancura del pan, / se mira una túnica / y se pinta un espárrago". (Poesía completa, 1994b, p. 413-414)
} 
cubana, que parece constituida en la plenitud del siglo XVIII, el grupo familiar Manrique de Lara pintado por Vermay [figura 6] (LEZAMA, 1994, p. 92).

La pintura de Jean Baptiste Vermay (1786-1833) es una muestra de pintura académica que no evidencia elementos propios de la cubanidad. Como fundador de la Academia de San Alejandro en La Habana, el retrato de la familia Manrique de Lara continúa la técnica neoclásica [figura 6]. Luego será Escobar (su nombre completo es Vicente Escobar y Flórez) quien rechazará la inclusión del paisaje cubano, ya que "viaja por academias, suspira ante la clásica campiña toscana, pero jamás cala una piña ni ve trepar una palmera” (p. 92). Lezama en sus juicios sobre la pintura (Escobar vivió entre 1757 y 1834) de ambos siglos evidencia una mayor preocupación en cómo es percibido y plasmado el paisaje que en la naturaleza social. Así, no se preocupa en enunciar en su ensayo otros temas de la pintura como el retrato. Por ejemplo, un pintor como Escobar [figura 3] recibe la atención de la crítica e historiadora del arte Adelaida de Juan como retratista de los "personajes de alcurnia oficial y económica" (JUAN, 1980, p. 8) y sus alabanzas por su "mayor gracia y fidelidad realista, [que] dejó una colección de retratos de los gobernadores y de las principales familias de la isla” (p. 8). La característica más notoria que Juan también observa en este pintor es el uso del recurso renacentista, poco usual en la pintura cubana, de abrir una ventana al lado de la figura para dejar entrar una breve visión de la bahía de La Habana (p. 8).

Otro elemento que el ensayista sitúa fuera de su historia de la pintura y la poesía se relaciona con la forma misma de representación de la población cubana, sobre todo del negro. En este sentido, no menciona que Escobar, mulato de nacimiento, rechaza el retrato de los rostros más oscuros con la única excepción de un músico de Matanzas pintado por él (BOLÍVAR), ni nombra al pintor Nicolás de la Escalera como el primer artista que incluye a un esclavo negro en su pintura sobre el primer conde de la Casa Bayona (JUAN, 1980, p. 23). Cuando menciona a Escalera lo hace estrictamente en el contexto de la pintura religiosa (las pinturas en la Iglesia de Santa María del Rosario): "Ese morado, más que en la frutilla entresacada por Rubalcava, me gusta recorrerlo en los mantos y pliegues que Escalera deja caer suavemente sobre sus santos pintados" (LEZAMA, 1994, p. 83).

El elemento racial no recibe una atención detenida por parte de Lezama Lima. Arnaldo Cruz- Malavé en El primitivo implorante señala que el cubano combate la idea de una expresión producto del negrismo y de la idea de lo sincrético mulato. Basándose en el “Coloquio con Juan Ramón Jiménez”, Cruz-Malavé destaca que la "sensibilidad negra" 
asumiría los aspectos negativos del "insularismo" cubano": "el desarraigo, el descentramiento, el exceso, la superficialidad" (CRUZ-MALAVÉ, 1994, p. 37-39); aunque, y en nota de pie de página, aclare que afirmar con certeza la impugnación lezamiana contra el elemento "folclorista" del negrismo sería inexacto. En todo caso, con respecto a la pintura, Lezama parece no detenerse en las expresiones de índole afrocubana de artistas de talla internacional como Wifredo Lam, cuya obra aparece en las portadas de Orígenes, pero no en las páginas de crítica de arte del poeta.

Las figuras menos importantes mencionadas por José Lezama Lima sin mucho detenimiento, incluyen a los poetas menores del romanticismo (Ildefonso Estrada y Zenea, Federico Milanés, Gonzalo Roldán y Tristán de Jesús Medina), y a los grabadores [figura 7] extranjeros Garneray y Mialhe. Sobresale en el ensayo el enlace entre los poetas y los pintores, pues, según Lezama, estos poetas "le preparan un buen recibimiento al paisajismo de la pintura cubana en la segunda mitad del siglo XIX" (p. 95). Un paisajismo donde aparece el verdor del paisaje cubano, las palmeras y el bohío gracias a las manos de Esteban Chartrand y Dubois (1840-1883) [figura 8]. No obstante, el autor caribeño no se detiene mucho en la calidad del trabajo plástico del pintor de origen francés nacido en Matanzas, ya que para él aún la pintura es balbuceante con respecto al paisaje:

En esa segunda mitad del siglo XIX mientras la pintura muestra rasguños y balbuceos paisajistas, la poesía logra su plenitud al acercarse a la naturaleza, al esquivarla después, y por último en José Martí, donde ya la relación poesía-naturaleza alcanza su plenitud al ascender la poesía a propia naturaleza (LEZAMA, 1994, p. 96).

Cuando introduce a José Martí luego se disculpa asumiéndose como Ulises. "Pero antes de llegar a esa plenitud, tenemos, oh Telémaco, que dar un rodeo donde hay muchas cosas sabrosas que contar" (p. 96). En ese retorno, el escritor se detiene en Julián del Casal, Luisa Pérez Zambrana, Juana Borrero y Cecilia Valdés. Sobresale aquí la reiterada presencia de la pintora Juana Borrero, cuya obra los Negritos [figura 5] aparece comparada con la Gioconda de Leonardo Da Vinci [figura 9]. Una analogía que nos hace pensar en la peculiaridad de la lectura lezamiana del cuadro de la artista, una exégesis que busca una integración de la obra a una tradición estética reconocida, pero con una curiosidad: la extrapolación del trabajo de Juana Borrero y su conversión en otro. No se trata de una sustitución (no es explícito cuál es la nueva obra que sustituye a la original) sino de una conversión de ese original. En el fondo a esta operación subyace una conciencia inventiva, un proceso ficcionalizante que rompe con el 
pacto entre ícono-cosa, entre el objeto "Los negritos" y su representación pictórica. Al final, el cuadro puede ser leído como y bajo la figura de cualquier otro:

Las vivencias profundas que produce la contemplación de los Negritos, son semejantes a las que produce La Gioconda. No creáis que deliro. Lo que en un sitio cualquiera puede intentarse con el enigma de una dama renacentista aislada en un coro de rocas, puede intentarse también en otro con enigmáticos negritos sonrientes [...]. Yo no hablo de la falsa categoría de lo cualitativo alcanzado en un arte, sino de las vivencias profundas que produce en el espectador el reto de las instantáneas aglomeraciones de lo que es verdaderamente configurador en el hombre (LEZAMA, 1994, p. 99-100).

Esta equiparación es fundamental en el ensayo como antesala a la gran sustitución que Roberto Méndez percibe como el "culmen" de "Paralelos...", pero no es la única. En la lectura del crítico la afirmación arriesgada de Lezama sobre la obra los Negritos, como "la única pintura genial del siglo XIX nuestro" (LEZAMA, 1994, p. 79) "apunta hacia una cadena de significados que se ilumina" por un "súbito":

La relación de Casal y Juana Borrero en la casa de Puentes Grandes, vista como arquetipo de la época perdida del modernismo en Cuba, la genialidad de la joven que no llega a rendir sus mejores frutos por su temprana muerte, su experiencia final del exilio donde pinta ese último cuadro, y la lejanía de Cuba, donde mueren en la manigua, su novio, Carlos Pío Uhrbach y el mayor de nuestros modernistas: José Martí (MÉNDEZ).

La relación de Borrero con Martí se hace evidente en la interpretación de Méndez y posibilita la estética de la sustitución nombrada anteriormente. Una "sustitución" que aparece claramente en las últimas palabras del ensayo.

De pronto se oyen las reyertas de los reyes en la tienda maldita de Agamenón. Hay una página arrancada. Me detengo absorto ante ese vacío. Pero mi perplejo se puebla, allí están, uno tras otro, los tres negritos de Juana Borrero. La página arrancada ha servido de fondo a la sonrisa acumulativa e indescifrable del cubano (LEZAMA, 1994, p. 106).

\subsubsection{El paisaje, Martí}

El paisaje es uno de los temas de "Paralelos..." que aparece, tal vez, con una importancia menor relacionada, sobre todo, con los pintores románticos y grabadores como Mialhe y Garneray. Aunque se trata de una manifestación "balbuceante" en el caso cubano, la pintura de paisaje se convierte en el centro de la expresión visual moderna en la Isla. La intuición de críticos como Ruskin a este respecto es certera: 
Desprovido também de beleza, o homem moderno passa a "roubar" a beleza da natureza, e a pintura de paisagem se torna, assim, a repositória dessa "beleza roubada". Ruskin, consciente dos principios evanescentes da época moderna e de sua acrescente rejeição à figura no território da arte, prevê, bem antes do surgimento dos Impressionistas na França, que os maiores pintores irão se dedicar à paisagem, e que irão superar em importancia os poetas (KERN, 2010, p. 19).

El impresionismo, con su mirada renovadora sobre la naturaleza, se convertirá en el primer paso hacia una verdadera modernidad en la pintura. Pero como en Cuba no existía una corriente tan innovadora sino un paisajismo que, en términos lezamianos, es "menor, gracioso y reiterado", y cuyo mejor exponente es Chartrand [figura 8] (LEZAMA, 1994, p. 95), habría que realizar otra nueva sustitución donde la poesía cumple el destino que cabría a la pintura. Frente a un paisajismo de tipo realista que busca una mayor verosimilitud con respecto al objeto representado, la poesía se convierte en naturaleza misma:

En esa segunda mitad del siglo XIX, mientras la pintura muestra rasguños y balbuceos paisajistas, la poesía logra su plenitud al acercarse a la naturaleza, al esquivarla después, y por último en José Martí, donde ya la relación poesía-naturaleza alcanza su plenitud al ascender la poesía a propia naturaleza (LEZAMA, 1994, p. 96).

La organicidad propia de la naturaleza parece existir en la poesía de Martí, pero también ese otro aspecto que Lezama le asigna, según la interpretación de Gustavo Pellón. Ese segundo aspecto hace de lo natural una entidad susceptible de ser creada por el hombre mediante la imagen poética (PELLÓN, 2005, p. 64-66) y no una ajena y antagónica con respecto a éste. De este modo, la poesía de Martí es una expresión poética "orgánica" que convierte a la naturaleza en un elemento cultural mediante la imagen. Quizás de este modo pueda entenderse la metáfora del hombre natural empleada por Martí en Nuestra América, donde escribe:

Por eso el libro importado ha sido vencido en América por el hombre natural. Los hombres naturales han vencido a los letrados artificiales. El mestizo autóctono ha vencido al criollo exótico. No hay batalla entre la civilización y la barbarie, sino entre la falsa erudición y la naturaleza. El hombre natural es bueno, y acata y premia la inteligencia superior, mientras ésta no se vale de su sumisión para dañarle, o le ofende prescindiendo de él, que es cosa que no perdona el hombre natural, dispuesto a recobrar por la fuerza el respeto de quien le hiere la susceptibilidad o le perjudica el interés (MARTÍ, 1985, p. 34).

El hombre natural se convierte así en un hombre autóctono, que no sigue las enseñanzas "artificiales" e inaplicables del extranjero a una América que posee unas circunstancias 
especiales y específicas. Igualmente, equivale a un buen salvaje, gracias a su sumisión y a una bondad inherente que lo colocan en un grado inferior respecto a una inteligencia superior gobernante. No obstante, es el hombre propio, espontáneo, que fiel a sus raíces es capaz de hacerse valer y derrocar al tirano cuando es desdeñado. Un individuo que recuerda la metáfora martiana del árbol señalada por Arnaldo Cruz-Malavé en El primitivo implorante. Según esta figura, la raíz-tronco representa el ser natural americano y su copa, la cultura. El eje de la autoctonía en Martí es más importante que la copa cultural, pues ésta depende de la primera. Así, Martí, según Cruz-Malavé, realiza una propuesta antagónica a Lezama, para quien la “raíz-tronco de la autoctonía [está] en función de la copa cultural” (CRUZ-MALAVÉ, 1994, p. 44). La mirada de Martí hacia la naturaleza y su propuesta de un hombre natural como metáfora cultural americana es equiparable a la concepción moderna de paisaje operada por los impresionistas. La observación de Martí no es inocente como la pintura de los paisajistas que Lezama critica.

Como se sabe, "el Apóstol" es una figura histórica de dimensiones universales que conjugó el ejercicio literario, como narrador y poeta, con el periodismo e, inclusive, las armas. Sus ideas, sus obras y su muerte en el campo de batalla lo convierten en un héroe nacional en la isla y en un personaje que ciertamente tiene un gran peso en el pensamiento de Lezama. Su presencia en "Paralelos..." representa el elemento que, junto con los otros personajes y situaciones, cohesiona la noción de una era imaginaria cubana y posibilita el contrapunto con la dimensión pictórica. En este diálogo, la pintura decimonónica de paisaje resulta inferior a la expresión poética, pero no es la única posibilidad de lectura. Esta misma expresión plástica permite un contexto más amplio que remite a la modernidad pictórica y al impresionismo y, en este sentido, es el origen de varias reflexiones acerca de la pintura cubana. Inclusive en la parte dedicada al autor del Protocolo de antigüedades, José Joaquín García, se refiere a los colores "cubanos", de acuerdo a un trasfondo paisajístico (LEZAMA, 1994, p. 77). Otras reflexiones, no necesariamente de José Lezama Lima, indican lazos entre el impresionismo, la idea de un ojo inocente y las prácticas primitivistas en la pintura. Son vínculos propios de la modernidad que sitúan al poeta y ensayista frente a este problemático periodo temporal. Lo curioso es que a pesar de su meditación acerca del primitivismo, por ejemplo, surjan otras vetas interpretativas sobre sus obras que lo acercan más a la posmodernidad y no tanto a la modernidad. Una situación que recuerda la reticencia del autor hacia la unilateralidad de las definiciones. 


\subsection{ECFRASIS (EKPHRASIS) Y UT PICTURA POESIS}

Antes de continuar con el análisis de las relaciones entre la pintura y la poesía, explicaremos los dos conceptos que enlazan estas manifestaciones artísticas. Ambos han sufrido reinterpretaciones y modificaciones a lo largo del tiempo, que nos permiten, por ejemplo, ubicar a José Lezama Lima en la estela de poetas-críticos como Baudelaire. Aunque no tratemos minuciosamente cada una de estas "nuevas lecturas", nos detendremos lo suficiente como para percibir los cambios más significativos y la forma como estos posibilitan otra mirada acerca del vínculo entre las artes hermanas.

La ekphrasis o ecfrasis es un procedimiento retórico-discursivo desarrollado por los rétores de los siglos III y IV d.C y explicado por Hermógenes en su Ecphrasis. Progymnasmata, como una descripción extendida, minuciosa y expresiva, que permitía "presentar el objeto ante los ojos" gracias a la virtud de la energeia (KRIEGER, 1992, p. 7). La misma palabra "progymnasmata" aludía a "los ejercicios retóricos para ejercitar a los alumnos en la práctica de la escritura", operación que incluía a la ecfrasis como una de las de mayor complejidad. De acuerdo a Isabel Lozano-Renieblas, esta capacidad de crear una imagen visual posibilitaba para los antiguos la distinción entre la ecfrasis y la diégesis o narración, mientras que la energeia o enárgeia era considerada como "la posibilidad de generar la potencia visual", que no es tanto un rasgo del lenguaje como del enunciador, quien tendrá que hacer vívido al auditorio lo que describe. Esta crítica agrega, además, que la enárgeia posee una estrecha relación con la fantasía, ya que ésta era entendida como la “capacidad para reproducir imágenes, como representación mental susceptible de expresarse mediante el discurso verbal y como objeto representado" (LOZANO-RENIEBLAS, 2005, p. 31-32). De este modo, la fantasía de convierte en un recurso indispensable para crear la intensidad visual de la enárgeia.

Con el paso del tiempo la ecfrasis perdió su función como creación de imagen visual de cualquier objeto mediante el discurso verbal y se articuló únicamente como la descripción vívida en torno a un objeto plástico. Desde esta dimensión se han desarrollado y se continúan estudiando las relaciones entre los lenguajes verbal y visual. Ya a comienzos de los años sesenta críticos como Jean Hagstrum o Leo Spitzer retoman el concepto en sus textos The Sister arts: the tradition of Literary pictorialism and English Poetry from Dryden to Gray 
(1958) y The ode on a Grecian Urn, or content vs metagrammar (1962), respectivamente. Ahora bien, en la actualidad son numerosos los estudiosos que se dedican a explorar estas relaciones interartísticas. Así, encontramos en la producción crítica de los años noventa a W.J.T Mitchell (Ekphrasis and the Other, 1994), James Heffernan (Museum of Words. The poetics of Ekphrasis from Homer to Ashbery, 1993), Claus Clüver ("Ekphrasis reconsidered. On verbal representations of Non-verbal texts", 1997), Peter Wagner (Icons, Texts, Iconotexts: Essays on Ekphrasis and Intermediality, 1996), Murray Krieger (Ekphrasis. The Illusion of the Natural Sign, 1992), Michael Riffaterre (“L'illusion d'ekphrasis", 1994) y Valerie Robillard (Pictures into words: Theoretical and Descriptive Approaches to Ekphrasis, 1998), entre otros. En el ámbito de la lengua española hallamos a Luz Aurora Pimentel (El espacio en la ficción. Ficciones espaciales, 2001), Danilo Albero (La ecfrasis como mímesis, 2007), Antonio Monegal (En los límites de la diferencia. Poesía e imagen en las vanguardias hispánicas, 1998) y Victoria Pineda (La invención de la ecfrasis, 2000). Para nuestro análisis nos enfocaremos principalmente en la noción de ecfrasis presentada por Pimentel.

En su artículo "Ecfrasis y lecturas iconotextuales" (2003), publicado originalmente en Poligrafías: Revista de literatura comparada de la Universidad Nacional Autónoma de México (UNAM), esta crítica recoge las nociones de ecfrasis de Leo Spitzer, James Heffernan, Claus Clüver y resume la suya propia -consignada en su libro El espacio en la ficción. Ficciones espaciales. Para nuestros fines nos interesan sobremanera la concepción de Cluver mencionada en este artículo y la de la propia autora. Así, para Clüver, la ecfrasis es "la representación verbal de un texto real o ficticio compuesto de un sistema sígnico no verbal" (CLÜVER, 1997, p. 26). Es interesante destacar que, como señala Pimentel unas líneas más adelante, a partir de este carácter relacional del texto verbal con respecto al objeto plástico habría también una relación intersemiótica e intertextual. Siguiendo a esta autora, este último fenómeno es evidente en Clüver al otorgar el énfasis en la textualidad: el objeto plástico es un "texto" no verbal representado en uno verbal.

Ahora bien, para Pimentel la ecfrasis puede ser descrita a partir de los siguientes tipos: referencial, nocional y referencial genérica. En la ecfrasis referencial el objeto plástico tiene una existencia material autónoma; en la nocional, el objeto "representado" "solamente existe en y por el lenguaje"; y, en la referencial genérica no hay un objeto plástico preciso sino "configuraciones descriptivas que remiten a un estilo o a una síntesis imaginaria de varios objetos plásticos de un artista" (PIMENTEL). Los ejemplos más claros son, de acuerdo a ella, 
los cuadros descriptivos en En busca del tiempo perdido que evocan a Manet sin mencionar una obra específica.

Para finalizar, queremos aproximarnos al concepto de ut pictura poesis con el objetivo de trazar una divisoria de aguas entre la idea horaciana y la ecfrasis. De modo muy general, la diferencia entre ambas es la amplitud de la ecfrasis al analizar la forma como la obra plástica se recrea en cualquier tipo de texto verbal (y no solamente poético). Históricamente la noción de ut pictura poesis tendría como antecesora la definición de la pintura como "poesía muda" y la poesía como "pintura que habla" de Simónides de Ceos, un poeta del siglo VI a.C. Luego con la Ars poética horaciana tendríamos la ya conocida fórmula que ha sido interpretada y reinterpretada en términos de los límites entre las artes. Aunque no vamos a centrarnos específicamente en la definición de estas fronteras, sí queremos destacar que el Laocoonte de Lessing se enmarca en esta discusión, y que textos como el de Aguinaldo José Gonçalves, Laokoon revisitado. Relações homológicas entre texto e imagem (1994), parten de esta reflexión. En él podemos leer los diálogos entre la poesía y la pintura gracias a poetas y pintores como Baudelaire, Cézanne, Corot Ingres y Mallarmé, entre muchos más. Desde su punto de vista, no hay una división rotunda entre ambas expresiones estéticas, ya que el símil (“como la pintura la poesía”) presupone una relación doble: de independencia y aproximación. En las próximas páginas trabajaremos algunos de los planteamientos de Gonçalves a la luz de lo que consideramos una posible historia y crítica de arte lezamiana.

\subsubsection{La pintura para Lezama: aproximaciones a la relación poesía-pintura desde el Laokoon revisitado}

En Laokoon revisitado. Relações homológicas entre texto e imagem (1994), Aguinaldo José Gonçalves comienza con un análisis acerca de la distinción tajante de Lessing entre las artes temporales (la música y la poesía) y las artes espaciales (la pintura) como el sustento de una reflexión que más que una diferenciación posibilita un encuentro, una aproximación entre un repertorio variado de poetas y de pintores decimonónicos y del siglo XX. Entre estos últimos vale la pena destacar a las parejas João Cabral de Melo Neto/Joan Miró, Oswald de Andrade/Piet Mondrian y Manuel Bandeira/René Magritte. No obstante, vamos a centrarnos en la proyectada pareja del siglo XIX Baudelaire/Cézanne e intentaremos una hipótesis o 
esbozo de lo que consideramos los cimientos de la concepción dialógica lezamiana entre las artes y, más aún, de su propia concepción de crítica de arte.

Son varios los elementos que nos permiten retomar a Baudelaire y elaborar un cierre de la reflexión desarrollada hasta aquí sobre el carácter relacional de las dos expresiones artísticas y el cariz de la crítica de arte vista a través del ensayo literario lezamiano. Así, queremos destacar los siguientes rasgos presentes en la lectura de Gonçalves: la música como paradigma formal para las artes desde el romanticismo, la noción de la pintura como lenguaje, el sistema de "las correspondencias" como un lazo entre las artes dentro de los medios de cada una, la preferencia plástica de Baudelaire por el color frente al dibujo, la poesis como un común denominador, la búsqueda de la expresión del dinamismo en la pintura y la existencia de una conciliación entre la razón y la sensibilidad como los ideales baudelerianos que aparecen en la pintura de Cézanne.

A primera vista, varios de estos elementos han sido mencionados a lo largo del capítulo. Ideas como la poiesis o el rasgo creativo común a las artes se relaciona con el acercamiento de cada una de estas expresiones desde su posición autónoma, sin jerarquización o rivalidad. No obstante, hay algunas ideas que por su novedad merecen un desarrollo aparte en las siguientes líneas.

Uno de los acentos que nos interesan es el énfasis en la música como arte que se aparta de la mímesis. De acuerdo a Gonçalves, con el romanticismo la expresión Ut pictura poesis debería reemplazarse por Ut musica poesis. Este giro, que el crítico lee en El espejo y la lámpara de M.H. Abrams, presupone que la música asume un lugar sobresaliente dentro de las artes por la ausencia de un referente externo y que los poetas comienzan a privilegiar sus efectos inmediatos en el receptor. De ahí que comiencen a favorecer la sonoridad y la melodía del verso por encima del sentido de las palabras. Una intención que apunta al alcance de la gran expresividad propia de la música, y en la que, en palabras de Gonçalves, tanto los pintores como los autores líricos "passaram a experimentar formas sonoras, a fragrância musical e a harmonia das cores, que, [...] Baudelaire apreende e analisa nas pinturas de Delacroix [figura 21] y de outros pintores no 'Salon de 1846"” (GONÇALVES, 1994, p. 101). Una alianza entre los efectos musicales y el uso de imágenes a semejanza de cuadros que no es desconocida en la literatura hispanoamericana. Como ya hemos mencionado, el modernismo hace uso del lenguaje pictórico por medio de la referencia a colores y el empleo de .metáforas que evocan obras plásticas. También el mismo Lezama usaría un lenguaje lleno de sugerencias 
plásticas en sus poemas (vimos ya como ejemplo el poema "Me hace propenso" de Fragmentos a su imán). Sin embargo, el tema de la música parece ir más allá. Textos como el de Sarduy nos recuerdan el énfasis de Lezama en el elemento fonético. En sus palabras, para el poeta y novelista "la prioridad formal es tal que se trata de la fonética propiamente dicha" (SARDUY, 1969, p. 65), y completa con una anécdota sobre la importancia de la disposición de los sonidos: tras un encuentro donde comentan un espectáculo de ballet, Sarduy recuerda en la voz, la entonación, las "largas vocales abiertas", la "respiración arrítmica" y en las "rupturas de bajo albanbergiano" (SARDUY, 1969, p.62), el particular compañero musical de la metáfora lezamiana. Una imagen de la peculiaridad del lenguaje del autor de Paradiso presente en la vida cotidiana y que continúa en la voz de sus ensayos.

Otra situación que nos permite leer un parentesco entre Baudelaire y Lezama a nivel de la crítica de arte podemos encontrarla en la propensión del primero hacia aquellos pintores que recurren al color como su elemento expresivo particular. Es lo que sucede con Delacroix que, como artista admirado por Baudelaire, lo emplea "na busca de uma subversão desse conceito clásico de beleza, para a recuperação do sentido dinâmico da superficie plana bidimensional" (GONÇALVES, 1994, p. 120). De acuerdo a este crítico, la posición incómoda de un pintor como Dominique Ingres proviene de su inclinación hacia la herencia clásica recibida, lo que convierte su arte en una paradoja en tiempos del romanticismo, ya que su medio de indagación estético es el dibujo. En las convenciones pictóricas, éste se emparenta con la línea y el límite, con el estatismo, mientras que el color obedece más a la viveza, al movimiento.

En Lezama la preferencia por el trazo colorista es notable. La observamos en los pintores aludidos en "Paralelos..." y también en otros ensayos donde la pintura no aparece únicamente como una referencia sino como un eje desde el cual puede explicarse el proceso metafórico de las artes. Textos como La expresión americana u "Homenaje a René Portocarrero" evidencian la predilección del autor cubano hacia obras y artistas cuyo rasgo distintivo es el empleo de la tonalidad y no tanto la perspectiva o el dibujo. De este modo, y al igual que Baudelaire, el poeta caribeño no privilegia la concepción clásica o neoclásica, ya que artistas como Rafael, David, Ingres o Poussin no son mencionados, mientras que pintores como Uccello, Brueghel, Jan Van Eyck, Roger Van der Weiden, Simone Martini, los hermanos Limbourg (autores del Libro de horas del Duque de Berry), Monet, Utrillo, Cézanne, Van Gogh, Picasso, Kandinsky, Klee, entre otros, hacen parte de su canon de pintores, un catálogo que orbita alrededor de los siglos XIV y XVI con los pintores del estilo gótico internacional, de la escuela flamenca y del 
primer renacimientos italiano, y que también incluye a los impresionistas, post-impresionistas, los primitivos $^{34}$ y los vanguardistas. Cabe destacar que desde esta mirada, también la perspectiva, como se concibe en el Renacimiento, colabora con la rigidez y, en consecuencia, sería una característica pictórica poco tenida en cuenta en el recorte del poeta. En palabras de Gonçalves:

Como se sabe o nascimento, o nascimento da pintura, como hoje a reconhecemos, deve-se ao Renascimento, à descoberta da perspectiva a ao seu aprimoramento, graças aos inúmeros tratados sobre tal conquista técnica. Esse fato, de importância determinante para a história da pintura, tornou-se uma das barreiras más sólidas para a evolução da própria pintura. Uma vez entendida e dominada pelas formas de representação naturalistas da arte clássica, passou a ser dominadora e doutrinária, dificultando sobremaneira a conquista do outro espaço, aquele das relações internas do sistema pictórico, que promove o dinâmico (GONÇALVES, 1994, p.69).

Una última idea llama nuestra atención sobre este entronque entre Baudelaire y Lezama como críticos de arte: la postulación, por parte de Gonçalves, de Cézanne como el pintor que proyecta, a posteriori, los ideales críticos del poeta francés. Como decíamos, es una idea que nos resulta interesante porque encierra una matriz conciliadora entre un arte de la sensación visual donde predomina el color y un proceso racional, de dominio de ese primer impulso visual. Según este autor:

É assim que para ele existem duas necessidades imprescindíveis: dominar a visão através das sensações de cor e dominar a emoção através de "um bom método de construção". É por esses fundamentos de Cézanne que se lhe confere a obstinada tentativa de ver o mundo "objetivamente", e que é o ponto básico que o distingue dos impressionistas que viam o mundo como se apresentava aos seus sentidos em várias luzes ou de diferentes pontos de vista (GONÇALVES, 1994, p. 180).

En este sentido vale la pena preguntarse si en Lezama se evidencia este carácter conciliador entre técnica e intuición, entre procesos racionales y sensoriales. Intentaremos alcanzar alguna respuesta en el próximo capítulo cuando trabajemos su ensayo de crítica "Homenaje a René Portocarrero". Así, tal vez sea posible o no percibir si Portocarrero

\footnotetext{
${ }^{34}$ En cuanto a los primitivos, pensamos en los dos momentos de su aparición en la historia del arte. Una primera con artistas italianos como Simone Martini [figura 23] (Escuela sienesa) o con los pintores flamencos de los siglos XV y XVI como Jan van Eyck, Roger van der Weiden, El Bosco o Pieter Brueguel el Viejo[figura 22]; una segunda, en el siglo XIX, con el Aduanero Rousseau [figura 14] (pintor que recibe gran atención por parte del escritor cubano en su novela Oppiano Licario). En el primer caso, la noción de primitivismo se debe a la permanencia en su expresión plástica de estilos medievales como el gótico o, como sucede especialmente con los flamencos, por su aislamiento de la revolución del Renacimiento y su carácter intelectual evidente en el estudio de la perspectiva a partir del desarrollo matemático u óptico (el arribo de los holandeses a este elemento pictórico será empírico e intuitivo). En el segundo, el arte primitivo podemos verlo, grosso modo, como un arte ingenuo, natural o sin artificios técnicos.
} 
representa para la propuesta ensayística de crítica de arte de Lezama lo mismo que Cézanne representaría para Baudelaire.

Por último, nos gustaría reflexionar sobre la obra plástica como "potencia de lenguaje" (GONÇALVES, 1994, p.115). Para Lezama, esta es una de las peculiaridades de la pintura, es un universo de imágenes que dialoga, en contrapunto, con la poesía. De modo que la reflexión presente en "Paralelos..." sobre las relaciones entre las artes hermanas, no concibe cada manifestación estética por separado sino como parte de un todo, de una poesis que, como creación, parte de un proceso de metaforización, de la invención de una obra de arte, pictórica o poética, que es un otro. Una otredad en el proceso creador en la que el nuevo objeto no guarda la misma relación de ícono-cosa o símbolo-concepto. Es ahí, a partir de esta perspectiva, que debemos entender la importancia de la creación de imágenes en "Paralelos..." o, dicho de otro modo, en su ficcionalización como historia artística cubana. De la misma manera que Hayden White proyecta la configuración histórica como "una operación literaria" "creadora de ficción" (WHITE, 2001, p.102), Lezama lee el devenir estético cubano como una gran fábula en donde caben las digresiones y el oscilar entre las eras imaginarias, los pasajes ecfrásticos, la descripción de la obras de pintores y poetas y también los juicios sobre ellas. Nada parece quedar exento de esta "potencia de ficcionalización". Inclusive los fragmentos donde una pintura es descrita sucede una recreación absoluta, y de un cuadro como "Los negritos" obtenemos una analogía con La Gioconda de Da Vinci [figura 9]. Así, debemos entender a "Paralelos...", como un modelo de ensayo lezamiano que procede como una gran lectura de la cultura, pero nunca como una lectura literal y sí como una desde la orilla ficcionalizante. 


\section{Capítulo II - CRÍTICA DE ARTE Y CRÍTICA POÉTICA: UNA MIRADA AL ENSAYO "HOMENAJE A RENÉ PORTOCARRERO"}

Tiene los ojos para la luz y los ojos del ciego que reconocen en la súmula de los instantes, entregados por los dedos. Visión y visión en lo oscuro y las matizaciones de los dedos.

José Lezama Lima. "Homenaje a René Portocarrero"

El extenso ensayo "Homenaje a René Portocarrero" aparece por primera vez en la publicación Cuba en la UNESCO del año 1964. Desde varios puntos de vista, este texto es representativo no solamente del estilo ensayístico lezamiano, el cual ya caracterizamos anteriormente mediante la presencia constante de la imagen poética y la alusión a culturas que perviven en el tiempo por su carácter imaginativo sino de su concepción acerca de lo que es la crítica de arte y su ejercicio. En este sentido, es, tal vez, el mejor ejemplo de la combinación de juicios críticos que resaltan el perfil de la obra plástica de este artista -no se puede perder de vista que se trata de un "homenaje"- con sus conocimientos sobre historia del arte, los cuales le permiten contextualizar, situar e insertar a Portocarrero dentro de una tradición pictórica amplia e internacional. También es paradigmático en tanto evidencia las características que, según el poeta, debería poseer una pieza artística, sin llegar a constituirse nunca en una preceptiva, ya que es una observación panorámica y un elogio de la trayectoria del pintor escrita en un momento en que éste ya ha alcanzado importantes logros, como la exposición de sus obras en 1944 en la Julian Levy Gallery y en el Museo de Arte Moderno de Nueva York, o su participación en la Bienal de Venecia de 1952 y en las Bienales de São Paulo de 1957 y 1963. En suma, un texto extenso para su género (41 páginas) que nos permitirá el análisis de una visión particular de la crítica de arte en Hispanoamérica; particularidad que se inscribe en el carácter de sus juicios y en la continuación de su propia poética mediante la presencia de conceptos como imagen, naturaleza y sobrenaturaleza.

\subsection{ENSAYO Y CRÍTICA: EL NACIMIENTO EN EL ERROR}

En un apartado de "Homenaje", Lezama señala que la creación parte de una falla, de una "frustración", que la crítica de arte debe leer como su trazo novedoso y originario. Un nuevo giro en su interpretación frente a la carencia o el vacío como motor creativo que nos lleva a 
pensar en una poética conformada por dos marcas de lectura distintas: una para la escritura de la historia y otra para la crítica. Veamos cómo esta última se configura:

Una crítica que sea creadora, es decir, que engendre en el espectador un acto naciente, un centro de simpatía irradiante, tiene que partir del animismo de lo cohesivo. En esos islotes de lo temporal expresivo, buscar la nueva especie que surge de lo logrado, pero no como una entelequia, sino con sus mismas razones oscuras, aun con sus frustraciones. Tiene así la crítica, logrado ese nuevo espíritu de lo cohesivo, que volverse hacia ese oscuro creador, hacia esa frustración que engendró un nuevo conocimiento, partiendo del error de lo no logrado (LEZAMA, 1994a, p. 242).

En este fragmento, el escritor cubano postula las características de la crítica en los siguientes términos. En primer lugar, deberá ser generadora de una afinidad entre el espectador y la obra de arte (debemos subrayar que el acto primordial es la observación del elemento plástico, no la lectura en sí de la crítica); pero también su nacimiento radica en la conciencia de que la obra no es una realidad finita, acabada, completa y perfecta sino que se genera a partir de una oscuridad, de un error o de una desviación con respecto a la trayectoria del artista y a otros exponentes, corrientes, movimientos y escuelas. Desde esa perspectiva, la crítica se instaura como una fuerza que conecta, cohesiona o vincula a la obra con el contexto artístico de su momento, pero también con la tradición. De ahí la colaboración estrecha entre ambas disciplinas, la historia y la crítica, para lograr una fuerza cohesiva entre la obra y esos "islotes de lo temporal expresivo", como Lezama denomina ese impulso de rótulo y clasificación que origina escuelas y movimientos.

Desde otra perspectiva, la idea del nacimiento de la crítica de arte gracias al error, recuerda al ensayo de Eduardo Grüner, mencionado en el capítulo anterior, y titulado, muy a propósito, "El ensayo, un género culpable". La culpabilidad del ensayo reside en que su propósito es el señalamiento del error, su develamiento y su destaque como fundador de la particularidad de la obra (literaria y no artística en el ensayo del crítico argentino). Una perspectiva que no es nueva y que proviene de la frase de Blanchot citada por Grüner: "todo escritor está atado a un error con el cual tiene un vínculo particular de intimidad" (GRÜNER, 1985, p. 52).

Ahora bien, en las siguientes páginas proponemos un acercamiento a las reflexiones de José Lezama Lima acerca de la tradición pictórica, los juicios sobre las pinturas de Portocarrero y la forma como éstas se insertan en la historia del arte. 


\subsection{LOS DIÁLOGOS Y LOS LÍMITES: LA HISTORIA Y LA CRÍTICA DE ARTE}

Con respecto a la relación entre la historia y la crítica de arte son posibles varias percepciones. No deja de ser llamativo que en un texto clásico como História da crítica de arte de Lionello Venturi aparezcan, desde las primeras líneas, críticas a la concepción acerca de la historia del arte, a su forma de enseñanza o a su desvinculación del mundo del juicio. Una de ellas es la reducción a la crónica en el siglo XIX, gracias también al positivismo, y que ocasionó que de forma improvisada surgiese la crítica. Un origen que el italiano cuestiona en la medida en que no hay una meditación y una discusión sobre el mundo del juicio y si una apelación a elementos extraños al arte como "la verdad científica, la ley moral y la historia de la costumbres" (VENTURI, 2007, p. 18). Pese a este comienzo, el argumento central del estudioso italiano girará en torno a la necesidad mutua entre la historia y la crítica. No existe comprensión de la obra de arte que no esté mediada por la historia, ya que la imaginación del mismo artista trabaja a partir de un modo histórico concreto de la tradición ${ }^{35}$. De este modo, el juicio del crítico estaría formado siempre por estos dos elementos: una percepción, una preferencia estética que informa el juicio y un horizonte temporal, que representa el contexto de génesis y desarrollo de la obra de arte.

Aunque parezca lógica la existencia de un contexto histórico que permite clasificar o relacionar una obra con una determinada corriente, autor o escuela, no siempre ha existido un total acuerdo entre la expresión artística y la historia. Con posterioridad a la Segunda Guerra Mundial aparece una crisis que vale la pena mencionar si se piensa en el contexto de producción de la crítica de arte lezamiana ${ }^{36}$. El origen de esta fractura es la destrucción de la idea de historia como progreso gracias al desastre de la guerra y a la presencia de regímenes totalitarios. De esta forma lo percibe Giulio Carlo Argan en el ensayo clásico antes mencionado, y que destaca cómo las corrientes informalistas, tanto europeas como americanas, se afirman como "el arte de la crisis y repelen cualquier lazo comprometedor con la historia: si la historia es violencia y terror, el arte no puede ser arte, a no ser colocándose

\footnotetext{
${ }^{35}$ Para Cézanne, por ejemplo, la historia y la tradición están directamente relacionadas con el quehacer pictórico. Según Giulio Carlo Argan en Arte y crítica de arte, este pintor francés pasaba horas en el Louvre estudiando los problemas técnicos de las pinturas de los grandes maestros. La finalidad de sus observaciones no era la copia sino la comprensión de la operación pictórica para su propia creación artística (ARGAN, 1993, p. 80-81).

${ }^{36}$ En La visualidad infinita, compilación de textos lezamianos sobre arte elaborada por Leonel Capote, se encuentra una relación cronológica donde los ensayos más tempranos de Lezama aparecen datados en 1935 y los últimos en 1972.
} 
fuera de la historia" (ARGAN, 1983, p. 88). Intentar posicionarse fuera de la corriente histórica abocaba, de acuerdo a este mismo crítico, a un dilema: o se insistía en el arte como valor y patrimonio de la humanidad que puede ser reconocido a través de la observación, la interpretación y el juicio, o se asumía una concepción artística del "mero fenómeno" sujeto a la descripción científica. Esta segunda posición surge con el informalismo y con el arte conceptual en general. La obra, desprovista de una acción intencional y sometida a la aplicación de un concepto que la convierte en un fenómeno como cualquier otro, no puede, según Argan, ser juzgada y sometida al flujo histórico ${ }^{37}$.

La aparente imposibilidad de vínculo entre el informalismo y las corrientes de arte conceptual con la historia se evidencian en la técnica. Para los artistas informalistas, por ejemplo, el trabajo con el material (color, piedra, metal) es fundamental. De ahí que en 1946, Jackson Pollock adopte la técnica del dripping [figura 10] y el resultado sean imágenes casuales donde sobresalen en la superficie filamentos, manchas y distintas gradaciones de color. Aunque el énfasis es en el material y no en la producción de una obra "acabada", el papel de este tipo de experimentación, que cuestiona la historicidad de las obras de arte realizadas bajo una acción consciente, con una técnica y una artesanía, nos permite lanzar una hipótesis de lectura sobre la crítica de arte lezamiana.

La crítica del poeta y novelista sobre uno de los pintores que se vincula con la corriente informalista puede brindarnos algunas orientaciones acerca de sus modos de lectura pictórica. Pensamos en estas formas de lectura como maneras que informan el juicio, la valoración de las obras artísticas y las propias preferencias estéticas del crítico. En este caso, queremos analizar brevemente cómo nuestro autor concibe la obra artística de Fayad Jamís, un pintor cuyos trabajos se emparentan con la corriente arriba mencionada. Si realizamos esta inclusión es porque queremos entender el carácter de los pareceres lezamianos y observar si, aún con artistas considerados como representantes de una expresión no figurativa, los criterios se mantienen iguales a los utilizados en relación a René Portocarrero. En todo caso, se trata aquí de un esbozo que tendrá resolución hacia el final de este capítulo.

"Ver a Fayad Jamís" [figura 11] es la presentación de una muestra del artista cubano de origen mexicano, escrita en 1971 y publicada en México en 1980, introducción ésta que no

\footnotetext{
${ }^{37}$ A nuestro juicio, esta afirmación es bastante discutible porque creemos que no existe una manera de negar la historicidad de una obra de arte. Lo que pensamos es que con el advenimiento de la modernidad los artistas plásticos comienzan a interrogarse por los medios de su expresión. Una situación que es llevada al límite en corrientes como el informalismo.
} 
es la única dedicada a un creador plástico asociado al arte no figurativo ${ }^{38}$. En ella, Lezama recurre constantemente a la imagen poética, a la descripción y a la comparación: "Fragmentos de árboles posibles que buscan otra unidad, impulsados por otro mundo que los tienta, como si gozaran de una poderosa emigración de las formas que saltan de sus rúbricas habituales" (LEZAMA, 1980, p. 8). Es un texto diferente con respecto a los escritos sobre Víctor Manuel, Amelia Peláez, Arístides Fernández, Mariano Rodríguez [figura 12] o sobre el mismo Portocarrero. El contraste quizás reside en que Jamís hizo parte del grupo de "Los Once", jóvenes artistas que influidos por la corriente informalista norteamericana participan en una exposición colectiva del 18 al 28 de abril de 1953 en La Rampa. En palabras de uno de sus integrantes, Antonio Vidal:

[En el grupo] teníamos ideas parecidas sobre la creación porque en el fondo lo que queríamos era hacer otro arte, diferente al que hacían Portocarrero, Mariano [...], de quienes éramos amigos. Estábamos influidos por la pintura norteamericana que algunos conocíamos por las revistas Goya y Art News. (PINO)

Así como en páginas anteriores mencionábamos que la crítica de arte de Octavio Paz se centraba en la idea de una obra de arte dada a la contemplación y no en las corrientes que prescinden de la figuración o que presuponen una transgresión a la valoración tradicional sobre el fenómeno estético, el caso de Lezama no parece ser muy distante. Pese a que seguramente conoce el trabajo abstracto de este grupo, solamente publica un texto sobre uno de los artistas, un pintor que también es poeta y que en 1962 gana el concurso Casa de las Américas de poesía. Una de las posibles razones para su elección es la amistad surgida entre ambos luego de la publicación de los poemas del pintor en Orígenes. Relación que nos recuerda esa versión de crítica-poética en los poemas dedicados a algunos plásticos y que interviene de manera substancial en su mirada analítica con respecto a las manifestaciones visuales en la isla. No podemos perder de vista que, en gran medida, es esta relación particular la que guía su selección. Un lazo de proximidad que se conjuga con un repertorio artístico que se inscribe, en su mayoría, en el arte "retiniano", preferencia estética que lo emparenta con Paz y que nos hace pensar si tuvo realmente contacto con expresiones contemporáneas que incluyesen performances o instalaciones. Desafortunadamente no encontramos documentos

\footnotetext{
${ }^{38}$ El otro artista es Luis Martínez Pedro (1910-1989), quien al lado de Salvador Corratgé [figura 20], Pedro de Oraá, Dolores (Loló) Soldevilla [figura 19], Wifredo Arcay, Sandú Darié, José Mijares, Rafael Soriano, Pedro Álvarez, Alberto Menocal hace parte del grupo “Diez pintores concretos” compuesto entre 1958-1961.
} 
que atestigüen un posible encuentro de este tipo hacia finales de los años sesenta y debemos restringirnos a nuestra curiosidad.

\subsection{OTRA VUELTA DE TUERCA A LA ESCRITURA LEZAMIANA SOBRE ARTE}

En el capítulo anterior mencionábamos la posibilidad de que los ensayos lezamianos sobre expresiones artísticas plásticas reclamasen autonomía. Una propuesta cuyo soporte era su propia densidad poética, pero que también conduce a su consideración como escritos que no pertenecen al terreno específico de la crítica de arte. Aunque no tomemos partido por una u otra posición, debemos resaltar la importancia de esta ambigüedad como eje de varias reflexiones. Entre ellas, la existencia de una tradición de escritura poética sobre temas pictóricos o escultóricos que data de 1850 e incluye a Théophile Gautier, Jules Laforgue, Walter Pater o Bernard Berenson. Un tipo de expresión escrita desarrollada por poetas, pero también por reconocidos críticos de arte como Pater o Berenson.

El surgimiento de esta crítica poética aparece de forma implícita con "La filosofía de la composición" de Edgar Allan Poe. Esta es la hipótesis de Joshua C. Taylor en su texto "Two visual excursions". Según él:

La alianza de poesía y pintura, más que de la narrativa y la pintura, fue importante para ambas. La poesía misma estaba cambiando, y había poco que extraer de su narrativa que interesara a los pintores. Al menos en Francia, y eventualmente en Inglaterra y a lo largo de Europa, a mediados del siglo el principio de evocación en la poesía tomó la primacía sobre la descripción, y los recursos y el alcance de la evocación obsesionaron a muchos escritores importantes. La estructura, tal como aparece descrita en el muy admirado ensayo de Poe, "La filosofía de la composición", es medida por la intensidad del impacto, no por su forma. Los círculos concéntricos en Flaubert, que se despliegan en asociaciones, hacen del poema una fuente y no un registro de la experiencia ${ }^{39}$ (TAYLOR, 1980, p. 33).

\footnotetext{
${ }^{39}$ En el original en inglés encontramos: "The alliance of poetry and painting, rather than narrative and painting, was important for both. Poetry itself was changing, and there was little in it in the way of narrative for painters to mind. At least in France and eventually in England and throughout Europe, by mid-century the principle of evocation took precedence over description in poetry, and the means and extent of evocation preoccupied many serious writers. Structure, such as that described in Poe's much admired essay, "The Philosophy of Composition" was measured by the intensity of the impact, not shape. Flaubert's concentric circles of expanding association made the poem a source, not a record of experience" (TAYLOR, 1980, p. 33).
} 
De acuerdo a este planteamiento, el origen de una escritura poética y crítica sobre arte surge de una nueva concepción donde prima el poder de evocación de la poesía y no tanto la presencia de la descripción. Dicho de otro modo, donde el lenguaje es verdaderamente expresivo y connota, en oposición a un lenguaje descriptivo "meramente" denotativo. Ahora bien, revisemos el pensamiento del mismo Poe y examinemos más de cerca dos de los rasgos que él prescribe para la expresión poética a partir de su análisis sobre "El cuervo".

En algunos fragmentos de "La filosofía de la composición" se evidencia la importancia del impacto que un poema debe causar para que sea considerado de mérito. Leemos, por ejemplo, que "la extensión de un poema debe hallarse en relación matemática con el mérito del mismo, esto es, con la elevación o la excitación que comporta; dicho de otro modo, con la cantidad de auténtico efecto poético con que pueda impresionar las almas" (POE). Sin embargo, la centralidad de este "impacto" o "impresión” también apunta a otras direcciones como las ideas de belleza y placer. Con respecto a estas dos nociones, nos llama la atención que sea la capacidad de causar impacto o impresión la que las subordina. De este modo, el placer más intenso se deriva de la contemplación de lo bello y, a su vez, lo bello posee la capacidad de producir una impresión, "una violenta y pura elevación del alma” (POE).

Según Poe, esta propiedad de producir un "arrobamiento" auténtico del alma es propia de la poesía y no de la prosa. De ahí que pueda pensarse que la importancia concedida a un lenguaje poético capaz de dejar una huella en el lector, se convierta en una especie de imperativo también para la creación pictórica. En este caso, la poiesis -entendida como creación pictórica o verbal- es valorada de acuerdo a su habilidad para dejar una impronta, evocación y sugerencia, y artistas como Corot o Ingres (en su última etapa) comienzan a ser vistos como "poéticos". Sobresale, por ejemplo, en el caso de este último sus "arabescos femeninos", los que, según Taylor, son percibidos por Gautier como "propios de un nuevo mundo poético del sentido y el símbolo"40 (TAYLOR, 1980, p. 33). Así, los artistas comienzan a ser evaluados de la misma forma que lo son los poetas, y en esta igualdad en los preceptos para ambas artes comienza el surgimiento de una crítica de arte que prefiere el lenguaje poético con su poder de sugerencia y evocación en el lector.

A partir de esta nueva concepción de lo poético, surge una nueva visión sobre la escritura de la crítica de arte en la que los poetas compiten con aquellos que apelan a un rigor científico. Y en esta pugna, la escritura crítica de los bardos aparece bajo la forma de la voz

\footnotetext{
${ }^{40}$ En el original leemos "as inhabitants of a new poetic world of sense and symbol" (TAYLOR, 1980, p. 33).
} 
poética, como la manera más válida de acercamiento al "aura" de una pintura. En palabras de Taylor:

Por supuesto que los poetas tuvieron que competir con los especialistas de los métodos convencionales como Champfleury y posteriormente Zola en su formulación de valores, pero los poetas ganaron, y hacia el final de siglo la mayoría de la escritura crítica sobre arte representaba una forma de poesía. Para describir la pintura uno debía dejarse llevar por su hechizo y escribir dentro de su aura poética especial. Una prosa dimensionada y simple no era suficiente para este trabajo. Un nuevo lenguaje expresivo tuvo que ser concebido para hablar convincentemente sobre valores plásticos, ya fuese con los intereses de Pater, Berenson o Laforgue. La manera como se aprendió a hablar sobre pintura tuvo un efecto sobre lo que los pintores fueron inspirados a hacer. El lenguaje ayudó a crear un mundo de arte, completamente separado y casi opuesto a la actividad rutinaria que la mayoría de la población consideraba como la realidad. Es una cuestión polémica si el lenguaje vino primero o la conciencia de aquellas cualidades que el lenguaje estaba tratando de describir. Ambas formas estuvieron entrelazadas y dependiendo la una de la otra. De hecho, nacieron juntas ${ }^{41}$ (TAYLOR, 1980, p. 33).

La proposición del crítico estadounidense permite observar dos cosas. La primera es la idea de una escritura de crítica de arte que esté acorde con las expresiones estéticas plásticas, es decir, que se asemeje también a una escritura artística; la otra, es la separación que esta crítica poética, junto con el arte que evalúa, ayuda a crear frente al mundo objetivo y a la existencia cotidiana de la mayoría de las personas. Esta escisión entre un arte al que se le atribuye valor y el mundo de las masas señala una problemática entre un "arte burgués" y un "arte popular" que será estudiado por Andreas Huyssen, entre otros críticos, desde la perspectiva literaria. Un tema que en el caso de Lezama apunta a otra ambigüedad que trabajaremos en el próximo apartado.

Ahora bien, otra mirada al texto de Taylor y a su concepción sobre el origen de una crítica poética, nos lleva de nuevo a la noción de placer que se deriva de la observación de lo bello. No obstante, vamos a aislar este rasgo de lo placentero y lo vamos a aproximar al

\footnotetext{
41 "Of course the poets had to compete with the clinicians like Champfleury and later Zola in their formulation of values, but the poets won out, and by the end of the century even much critical writing on art was a form of poetizing. To describe a painting one had to be taken into its spell and write within its special poetic aura. Simple, dimensioned prose was not enough for such a taste. A new expressive language had to be devised in order to talk convincingly about plastic values, whether with the concerns of Pater, Berenson or Laforgue. [...] The way one learned to talk about painting had its effect on what painters were encouraged to do. The language helped to create a world of art, quite separate and often opposed to the humdrum activity that the larger population considered reality. It is a moot point as to whether the language came first or an awareness of those qualities the language was trying to describe. They were intertwined and depended upon each other. In fact, they were born together (TAYLOR, 1980, p. 33).
} 
concepto de texto en críticos como Roland Barthes ${ }^{42}$. Así, desde esta mirada intentaremos nuevamente otra aproximación al ensayo de crítica de arte del poeta cubano.

En "De la obra al texto" (1971), Roland Barthes opone el concepto de texto al de obra y propone siete formas de percepción sobre el hecho textual. Entre ellas sobresalen, por ejemplo, la idea de una continuidad en la que el texto no se detiene en el estante de una librería; su carácter resistente a las meras clasificaciones de género, su dilación con respecto al significado -o su oposición a la relación arbitraria entre el significante y el significado-, su irreductibilidad a un significado unívoco, su lectura sin la presencia de un padre-autor que le otorgue una garantía, su exigencia de una colaboración práctica del lector y, por último, la ausencia de una primacía de un lenguaje sobre otro (BARTHES).

Pese a que no es necesario decir que el ensayo de crítica de arte del cubano, como texto, cumple varias de las características enunciadas anteriormente, sí nos parece importante mencionar su carácter dinámico y metamórfico. No solamente porque no es posible encasillarlo como "ensayo científico" o "ensayo puramente literario" sino porque también se relaciona con la idea de disfrute o placer. En las palabras del crítico francés:

El Texto está ligado al goce, es decir, al placer sin separación. Orden del significante, el Texto participa, a su manera, de una utopía social; antes que la Historia (suponiendo que ésta no escoja la barbarie), el Texto lleva a cabo, si no la transparencia de las relaciones sociales, al menos las de las relaciones de lenguaje: es el espacio en el que ningún lenguaje corta el camino a otro, en el que circulan los lenguajes (manteniendo el sentido circular del vocablo) (BARTHES).

El "Texto" lezamiano se constituye como un modelo de libertad en el que no hay primacía de un tipo de lenguaje específico y sí una circulación sin ataduras del lenguaje; en otras palabras, una "sujeción" a la reescritura, a la reinterpretación y a la intervención activa por parte del lector. Frente a las "Obras" de Flaubert, Proust, Balzac y Dumas, congeladas en el canon, el texto sugiere el movimiento hacia los límites de los géneros, un dinamismo que lo aproxima al placer, al disfrute, y no al mero consumo.

\footnotetext{
${ }^{42}$ Nos hemos basado fundamentalmente en dos escritos del crítico francés: "De la obra al texto" y en $O$ prazer do texto. La razón de esta escogencia es la centralidad del carácter "placentero" del hecho textual, un rasgo que nos interesa observar y resaltar en el caso de la escritura lezamiana. No obstante, y desde esta perspectiva, hemos dejado por fuera la noción de escritura, una idea central que, según Barthes, se define por una "cierta conciencia de la palabra". Así, "É escritor aquele para quem a linguagem constitui problema, que experimenta sua profundidade, não sua instrumentalidade ou sua beleza" (BARTHES, 2009, p. 210). Desde este punto de vista, este autor sostiene la idea de que en la nueva crítica -de la que él es un representante- no hay unidad en sus métodos, pero sí "un acto de plena escritura". De este modo, el escritor y el crítico ya no se definen como "el creador y el servidor", respectivamente, sino que ambos se hallan en la misma condición difícil de enfrentamiento con el lenguaje (BARTHES, 2009, p. 210).
} 
La misma idea de no pertenencia de nuestro autor al canon de ensayistas sobre el fenómeno estético también resulta diciente. Gracias a los trazos antes mencionados, el ensayo sobre crítica de arte del cubano es renuente al "estatismo" propio de este catálogo arquetípico de obras literarias. La cerrazón de las obras canónicas, su permanencia preservada e intacta a pesar del transcurso del tiempo y de los distintos lectores, se opone a las peculiaridades de la escritura lezamiana. Ensayo en todo el sentido del término, los textos sobre arte del cubano exploran las fronteras entre los géneros e indagan también acerca de las múltiples posibilidades que le ofrecen la historia y la crítica de arte. Una polifonía o contrapunto en su tejido que se opone a la caracterización de este género como "prosa de ideas". Por el contrario, en lugar de un discurso razonado, metódico, nos encontramos con un escrito de ecos poéticos donde se presenta un gran concierto de la cultura cuyo motivo es el pintor Portocarrero. Decimos motivo cuando deberíamos decir "excusa", ya que en realidad este artista a veces aparece desplazado del centro del ensayo. Probablemente una de las particularidades que no ha permitido de manera unánime entre los críticos la inclusión de Lezama en un corpus de ensayistas hispanoamericanos, del mismo lado de Octavio Paz o Alfonso Reyes, es, precisamente, este carácter acumulativo o heteróclito donde caben un sinnúmero de digresiones y no la preeminencia de un lenguaje organizado alrededor de una estructura expositivo-argumentativa. En este sentido, esta forma textual es otra manifestación de la poiesis, de la misma manera que lo pueden ser la lírica, las artes plásticas o la música; una obra estética que desde su tipología se mueve en una gran ambigüedad: la de la creación y las imágenes, y la de las nociones de la historia y la crítica de arte; imprecisión que el autor lleva al límite.

En cuanto a la noción de placer que se deriva del texto, queremos mencionar otra ambigüedad. Se trata de un punto medio entre éste y la fruición en el ensayo de crítica de arte del poeta. Decimos que existe una intersección entre ambos porque al mismo tiempo en que el primero proviene de la cultura y representa una práctica cómoda de lectura, la segunda causa incomodidad y coloca en estado de pérdida porque hace vacilar "as bases históricas, culturais, psicológicas do leitor, a consistência de seus gostos, de seus valores e de suas lembranças, faz entrar em crise sua relação com a linguagem" (BARTHES, 2004, p. 20-21). Ambos elementos están presentes sin ninguna preeminencia entre ellos, ya que la notable erudición del escritor cubano posibilita la alusión a un sinnúmero de referencias artísticas e históricas que ejemplifican su "devolver acrecido", pero, y de forma simultánea, también 
sitúan al lector en una posición que dista del "lugar común" al presentarle un lenguaje poético que dificulta su comprensión. Un obstáculo que no es inherente a los rasgos formales de los textos y que también orbita alrededor de estos dislocamientos a nivel de contenido que operan en el tejido ensayístico.

\subsection{LA DIATRIBA ENTRE LO ALTO Y LO BAJO: EL ARTE DE ORIGEN BURGUÉS Y LAS MASAS}

La inscripción del proyecto crítico y creativo de Lezama en lo que Leyla Perrone-Moisés denomina "altas literaturas" resulta fundamental para comprender su escritura y su posición ideológica. De esta forma, lo que hemos venido trabajando en las páginas anteriores, en términos del origen de una crítica poética de arte y de la inserción del ensayo lezamiano en la noción de "Texto" de Barthes, recibe una mayor claridad y posibilita enmarcar la tentativa del poeta y ensayista dentro del contexto de la modernidad.

En su libro, Altas literaturas, Leyla Perrone-Moisés se centra en la escritura crítica de autores modernos como Ezra Pound, T.S Eliot, Jorge Luis Borges, Octavio Paz, Italo Calvino, Michel Butor, Haroldo de Campos y Phillippe Sollers, y analiza, a partir de las posturas de cada uno, cómo perciben la historia literaria, cuáles son sus autores canónicos y los valores literarios que les permiten tal elección. Desde ese punto de vista, es posible resaltar dos de las conclusiones principales a las que ella llega: una concepción no lineal de la historia literaria, común a los escritores antes mencionados, y la noción de lectura de esos escritores-críticos como espacio que les permite situarse dentro de la historia literaria y reescribirla mediante la enunciación de juicios de valor; apreciaciones que, según PerroneMoisés, serían positivas -y no negativas como las de la crítica especializada. Un carácter positivo que "repousa sobre um conjunto de valores, que ora são comuns (os da tradição ou os do seu tempo), ora pessoais, ligados aos projetos de suas próprias obras de criação" (PERRONE-MOISÉS, 2003, p. 144).

Podemos percibir varios nexos entre la perspectiva ofrecida por Perrone-Moisés sobre los autores antes mencionados y la propuesta ensayística de Lezama. El primero es la percepción sobre el tiempo y la tradición, en la que no existe una confianza depositada en un recorrido lineal que conduce al progreso; y, el segundo, en el reconocimiento y formulación de valores por parte de estos escritores críticos que posibilitaron la escogencia de sus 
precursores dentro de la historia literaria. En cuanto a estos principios, vale la pena destacar algunos como la maestría técnica, la visualidad y sonoridad, la intensidad, la completud (y la fragmentación), la intransitividad, la impersonalidad, la universalidad y la novedad ${ }^{43}$.

La construcción de un proyecto literario que se cimenta en estos valores muestra una de las caras de la modernidad con la cual es posible identificar plenamente a un escritor como José Lezama Lima. El otro rostro, incluido más dentro de un plano ideológico, es posible verlo a partir de su postura frente a las vanguardias. En este último aspecto, vale la pena revisar su posición y también algunos estudios sobre la oposición entre una "alta cultura" y "una cultura de masas", o, como lo anunciamos en el título de este capítulo, la diatriba entre lo "alto" y lo "bajo". Una antítesis en la que, en apariencia, "una alta cultura" defendida por el modernismo se opone a una "cultura masificada" de extracción popular, que se vincula a la vida cotidiana ${ }^{44}$.

Un antagonismo entre lo "alto" y lo "bajo" forma parte de la propuesta cultural de lo que críticos como Andreas Huyssen llaman la "Gran División", es decir, un fraccionamiento que "no es sino el tipo de discurso que insiste en una distinción categórica entre arte elevado y cultura de masas" (HUYSSEN, 2002, p. 7). Una antinomia que no es una total oposición entre un arte bajo -asociado a las expresiones artísticas populares- y un arte elevado vinculado a la sociedad burguesa- sino que es, por el contrario, una lucha por parte de esa postura cultural elitizada contra las expresiones artísticas culturales que, paradójicamente, la permean y de las cuales busca autonomizarse. Una contradicción que Huyssen lee y revisa a partir de la teoría de Adorno, entre otras, y que también le posibilita el análisis de los planteamientos de Benjamin acerca de la dialéctica oculta entre el arte vanguardista y la confianza utópica en una cultura de masas.

\footnotetext{
${ }^{43}$ Estas características representan los valores comunes que destacan los escritores analizados por PerroneMoisés. Aunque hay algunos más, nos hemos detenido solamente en los que consideramos que habría en común con José Lezama Lima, autor que no menciona la ensayista. (PERRONE-MOISÉS, 2003, p. 143-173)

${ }^{44}$ En su Teoría de la vanguardia, Peter Bürger señala, por ejemplo, que "con los movimientos de vanguardia el subsistema artístico alcanza el estadio de la autocrítica" (BÜRGER, 1987, p. 62). Esta afirmación es importante en la medida en que, para él, la vanguardia lleva al límite procesos iniciados, ya desde finales del siglo XIX, por el esteticismo. Así, "La intención de los vanguardistas se puede definir como el intento de devolver a la práctica la experiencia estética (opuesta a la praxis vital) que creó el esteticismo. Aquello que más incomoda a la sociedad burguesa, ordenada por la racionalidad de los fines, debe convertirse en principio organizativo de la existencia" (BÜRGER, 1987, p. 81). A partir de esa ruptura con la sociedad iniciada por lo esteticistas -con quienes el arte se despliega en su "pureza" al desligarse de la vida práctica-, los vanguardistas desarrollarán un movimiento contrario. En lugar de estetizar la praxis vital (recordemos el dandismo), los movimientos vanguardistas se ocuparán de convertir el contexto de la vida cotidiana en el tema de sus obras.
} 
La idea de un arte vinculado a la realidad es una noción característica del proyecto vanguardista que, según Huyssen, lo diferencia notablemente del proyecto modernista. Lejos de afirmar una "institución arte" consagrada desde el esteticismo del siglo XIX y reafirmada en las dos décadas posteriores a la Segunda Guerra Mundial, de acuerdo con su periodización, la vanguardia se ocuparía de minar esa institución a partir de una actitud iconoclasta y anárquica que, en suma, "pretend[ía] transformar el aislamiento de la sociedad de l'art pour l'art -que reflejaba tanto la oposición a la sociedad burguesa como el j'accuse de Zola- en una rebelión activa que haría del arte una fuerza productiva para el cambio social” (HUYSSEN, 2002, p.26) ${ }^{45}$.

Con este marco, la propuesta de Lezama se inscribe en el proyecto moderno por su acercamiento a los valores que Perrone-Moisés señala como comunes a autores como Ezra Pound, T.S Eliot o Italo Calvino, y también porque su propia concepción de la escritura, su poética del barroco, su erudición y sus incontables referencias a diversas tradiciones culturales y filosóficas $^{46}$, hacen de él un autor que, desde las formulaciones de esta autora, no posee vínculos con un universo cotidiano, de la vida común, cuyas referencias culturales serían trabajadas desde otra perspectiva y donde el lenguaje no es trabajado como una artesanía "en filigrana".

Por otra parte, y a partir de la mirada de Huyssen, la postura de Lezama muestra el alejamiento típicamente modernista entre el arte y la praxis vital propia de las masas. Una distancia que no es insalvable en la medida en que la colectividad aparece privilegiada en su horizonte de pensamiento. Pero no cualquier idea de sociedad sino el de una comunidad cubana concebida desde el imaginario del poeta. Un lugar privilegiado donde confluyen la memoria y la erudición del autor para configurar mediante la escritura poética el carácter

\footnotetext{
${ }^{45}$ El punto de partida de Huyssen sobre esa "aparente" brecha entre el modernismo y la estética vanguardista es una de las tesis centrales de Bürger. Para este último, "los vanguardistas intentaron, pues, una superación del arte en el sentido hegeliano del término, porque el arte no había de ser destruido sin más, sino reconducido a la praxis vital, donde sería transformado y conservado" (BÜRGER, 1987, p. 103). De acuerdo a esta proposición, Huyssen no solamente sigue el planteamiento de Bürger sobre el vínculo vanguardista con una esfera vital, sino que también propone implícitamente un cambio en la terminología. Mientras que Bürger piensa en "el arte en la sociedad burguesa", Huyssen usa directamente la palabra "modernismo".

${ }^{46}$ Los otros dos perfiles trazados por Leyla Perrone-Moisés, y que se asemejan mucho al del cubano, son los de Octavio Paz, quien se caracteriza por "uma ambição de atualização enciclopédica", y el de Borges, cuyo enciclopedismo es "pessoal e caprichoso". Rasgos que, de acuerdo a ella, propician una divergencia entre ambos autores, pero que en Lezama pueden verse en conjunto, en combinación. Otra similitud entre el escritor caribeño y el mexicano es su visión sincrónica de la historia. En palabras de Perrone-Moisés, "o haicai japonês é visto por ele como uma forma muito moderna de poesia ocidental; o arcebispo de Hita (século XIV) pode ser lido à luz de Joyce, e Sor Juana Inés de La Cruz (século XVII), à luz de Lezama Lima" (PERRONE-MOISÉS, 1998, p. 34).
} 
cubano. No tanto una idiosincrasia sino una tradición y una historia cubanas, en las que la imaginación es el centro de irradiación ${ }^{47}$.

Ahora bien, nuestra reflexión acerca de la diatriba entre lo "alto" y lo "bajo" nos brinda un contexto ideológico importante para el análisis del ensayo lezamiano de crítica de arte. Como moderno, José Lezama Lima emplea las estrategias mencionadas anteriormente por Perrone-Moisés e incluso desarrolla una crítica de arte que busca la autonomía del género ensayístico gracias a sus recursos poéticos y a su trabajo con la forma y la sonoridad. Esta búsqueda, que no necesariamente presupone la ausencia de conceptos, como ya hemos señalado, proporciona de entrada un obstáculo para el lector común, poco acostumbrado al giro metafórico, a las palabras cultas o a las referencias a tradiciones o a culturas que, en apariencia, no tienen ningún vínculo con el tema que se está tratando. Estamos así frente a una muestra de una forma "alta" de la literatura de crítica de arte que se caracteriza por su total separación de la esfera de la cultura de masas y de la vida cotidiana ${ }^{48}$. No en vano los pintores seleccionados por el autor cubano le permiten circunscribir su análisis a las corrientes modernas y a los artistas de la llamada "vanguardia cubana", y un poco menos a los primeros síntomas de la no figuración, tal como sucede con Fayad Jamís [figura 11], entre otros. No es que no escriba sobre estos plásticos sino que, tal vez, su disposición y sus herramientas de comprensión conducen a una forma distinta de crítica de arte, una concepción diferente a la que observamos con Portocarrero o, inclusive, con Mariano Rodríguez [figura 12$]^{49}$.

\footnotetext{
${ }^{47}$ Nuevamente debemos citar el "Coloquio con Juan Ramón Jiménez". En este texto hallamos la alusión al mito como una proyección futura de la poiesis que permitiría entablar las bases de una sensibilidad insular cubana. La intervención de Lezama en el diálogo con el poeta español ejemplifica este propósito, pues afirma: "Yo desearía nada más que la introducción al estudio de las islas sirviese para integrar el mito que nos falta. Por eso he planteado el problema en su esencia poética, en el reino de la eterna sorpresa, donde, sin ir directamente a tropezarnos con el mito, es posible que éste se nos aparezca como sobrante inesperado" (LEZAMA, 1977, p. 51).

${ }^{48}$ Este distanciamiento en Lezama podemos leerlo también a través de la impronta dejada por Ortega y Gasset en el poeta cubano, ya que el pensamiento de aquél con sus textos y la Revista de Occidente marcó a toda una generación de intelectuales en Latinoamérica. Así lo señala también Pablo Helguera cuando afirma que este filósofo indicó las bases para la reflexión sobre la expresión visual, una "visión que permaneció prácticamente inescrutable hasta la década de los sesenta" (HELGUERA, Pablo. Las guerras de la contemplación. Los caminos de la crítica poética en Latinoamérica. Disponible en: http://universes-inuniverse.de/columna/col49/col49.htm. Consultada en: 8 ago. 2012). Al parecer el texto orteguiano más sobresaliente es La deshumanización del arte (1925), donde afirma que el carácter del arte nuevo es puramente intelectual y deshumanizado en cuanto a pasiones y emociones, ya que "sería un arte para artistas, y no para la masa de los hombres; será un arte de casa y no demótico" (ORTEGA Y GASSET, 1964, p.11).

${ }_{49}$ Pensamos que los textos de nuestro autor sobre las obras plásticas de ambos artistas -Jamís y Martínez Pedro- son diferentes con respecto al grueso de autores de la vanguardia cubana, como Arístides Fernández, Víctor Manuel, Alfredo Lozano, Amelia Peláez, Mariano Rodríguez y René Portocarrero. Las dos peculiaridades
} 


\subsection{UN ANÁLISIS EN FILIGRANA DEL ENSAYO "HOMENAJE A RENÉ PORTOCARRERO"}

Un ensayo tan extenso como el dedicado al pintor René Portocarrero requiere un análisis dividido en varias secciones. Este fraccionamiento obedece básicamente al examen sobre la manera en que Lezama Lima apela a la tradición o a la historia artística internacional (y también cubana), al análisis acerca de la continuidad en su crítica de arte de sus planteamientos sobre el sistema poético y, por último, a una revisión del concepto de primitivismo desde la expresión plástica. En cuanto a este último aspecto, cabe aclarar que no nos enfocaremos en un estudio desde el aspecto antropológico o filosófico, cuyo estudioso más destacado es Lucien Lévy-Bruhl, y sí en la comprensión de esta categoría del pensamiento a partir de su formulación en la pintura moderna y exclusivamente en el texto sobre Portocarrero 50 .

\subsubsection{La tradición: una historia artística en clave cubana}

En un apartado de "Homenaje...", Lezama destaca una falencia en la enseñanza de la historia del arte: la concepción lineal de la historia, una visión ausente de relieves y que avanza hacia una noción de progreso. Según él:

que nos permiten esta hipótesis son el uso de la descripción y la analogía como mecanismos formales y la ausencia de elementos de la historia del arte. De alguna manera, esta forma "distinta" de crítica sobre el objeto estético nos hace pensar que el análisis del cubano se halla todavía en manifestaciones figurativas o dadas al placer de ojo -arte retiniano, en palabras de Marcel Duchamp- y no en una "diferenciación" con respecto a temas como la imagen, centro de su sistema poético y soporte temático y formal de la totalidad de su obra.

${ }^{50}$ Pese a que la elección de otro artista como el Aduanero Rousseau resultaría muy interesante, corremos el riesgo de incurrir en la escritura de otra disertación. No obstante, es imperativo que mencionemos que este pintor primitivo le sirve a Lezama para exponer su concepción personal acerca de la poiesis, de la misma forma que lo hace con Portocarrero. De este modo, leemos en un fragmento de Oppiano Licario acerca del cuadro de Rousseau "La musa inspira al poeta" de 1909 [figura 14] que: "Aquí la vegetación indica la proximidad de los enlaces y lo germinativo, mientras que las figuras esbozan sus risueños arquetipos. La vegetación se orquesta en una sangre verdeante, los tonos de lo estelar son un azul rodado, gritando casi su movilidad, pero una secuencia de tonos bermejos, que tiene algo de arborescencia coralina, se fija como el remolino dentro del caos para comenzar el confiado origen de los mundos. En sus cuadros como primitivo no podemos dejar de contemplar los castillos, la escarcha y los árboles esquematizados, [...] que desfilan por El libro de horas del Duque de Berry" [figura 15] (LEZAMA, 1997, p. 33-34). Resulta curioso que Lezama lea el lienzo del Aduanero en el marco de una pintura gótica como El libro de horas. En este sentido, él desarrolla un desplazamiento que relaciona a una obra pictórica moderna con una medieval, gracias al ejercicio de una crítica basada en la "razón reminiscente". Recordemos que en el ensayo sobre Julián del Casal, el poeta aboga por un tipo de lectura intertextual basada en el "eco", en una memoria de la "frase entreoída", en una evocación del detalle, y no en una práctica de inventario que busca prescribir las fuentes a partir de una noción de la totalidad. 
He aquí un error muy difundido por la crítica de elementales solfeos de las habituales cátedras de historia del arte. Producto del facilismo, de muy escasas e inservibles intuiciones acerca de las obras cuya sola mecánica brinda, comienzan por aceptar un desarrollo sucesivo, como si en la obra de un creador no hubiese rectificaciones creadoras, vueltas a los comienzos, balbuceos aún en sus momentos de mayor madurez y cosas ganadas de un súbito (LEZAMA, 1994a, p. 241).

A partir de este fragmento es posible observar varios rasgos en su postura frente a la historia del arte. Por una parte, la asociación con el elemento musical brinda un marco en el que se plantea una clara oposición hacia un carácter secuencial o "sucesivo", ya que "los elementales solfeos" sugieren una lectura simple de notas que se suceden. Por otra parte, postula la existencia de una especie de movimiento circular y no rectilíneo de "avance" o "evolución" dentro de un mismo autor, es decir, un flujo que se asemeja más a un movimiento continuo de avance y retroceso. Así, da continuidad a los planteamientos sobre la historia que mencionábamos anteriormente en el análisis de "Paralelos...", pues, desde su perspectiva, siempre hay una especie de contrapunto o de diálogo entre dos o más instancias y no un simple transcurrir en línea recta como ocurre con una melodía monofónica. Es así como la monofonía es comparada con la enseñanza errónea en la historia del arte, y el avance sucesivo en línea recta, sin desvíos, sin retrocesos y sin giros inesperados, comúnmente asociado a la concepción histórica heredada de la Ilustración, se convierte en la imagen opuesta que el poeta erige de la cultura. Una imagen - la suya- más vinculada a la polifonía o a una fuga barroca, que al canto llano propio de la Edad Media ${ }^{51}$.

Un rasgo sobresaliente en el ensayo es la relación que Lezama establece entre Portocarrero y la tradición. En lugar de un procedimiento de clasificación y de inserción dentro de las llamadas escuelas o corrientes, el poeta vincula al pintor cubano con una constelación diversa de pintores. Así, cuando caracteriza el paisaje -o la ciudad, en el caso del artista de la Isla- como el resultado del movimiento de la imaginación hacia lo alejado -lo cercano será la casa-, afirma que en "Portocarrero es frecuente la fijación de esas ciudades en un espacio de lejanía y en un tiempo reconstruido" [figura 16] (LEZAMA, 1994a, p. 227).

\footnotetext{
${ }^{51}$ Julio Ramos en un seminario titulado "La escucha barroca" (clase-taller dictado en la Pontificia Universidad Católica de Chile) propone la idea de la sonoridad como una percepción sensorial que estaría en la base de la formación de las culturas. Este es un planteamiento muy interesante que podríamos transponer al caso lezamiano y a su lectura del barroco. Desde este enfoque, vemos una preocupación constante en el elemento sonoro y musical como modelo de interpretación, en este caso de la historia del arte. ("La escucha barroca". Disponible en http://www.letraspuc.cl/index.php?option=com_content\&view=article\&id=1176:seminario-dejulio-ramos-la-escucha-barroca\&catid=55:videos\&Itemid=412. Consultado en jun. 2013).
} 
Una afirmación que sitúa a este pintor en la estela de artistas que han trabajado en los términos de lo distante que "la imaginación logr[a] atrapar como un signo" (LEZAMA, 1994a, p. 226). Entre estos pintores encontramos a Iacopo Bellini (1400-1470), Andrea Mantegna (1431-1506) y J.M.W Turner (1775-1851), y, curiosamente, a un poeta, Percy Bysshe Shelley (1792-1822).

El modo como Lezama argumenta y coloca en relación a un artista cubano del siglo XX con artistas pertenecientes a corrientes diferentes nos llama bastante la atención. No tanto por esa operación contraria a la linealidad, a la jerarquización y clasificación esperada, ya que, como señalamos anteriormente, el poeta se opone al estatismo de las definiciones y a la concepción de la historia -incluso la artística- como un proceso rectilíneo donde, a la manera de un organismo vivo, existe un nacimiento y un desarrollo. Por el contrario, nos llama la atención porque su forma de argumentar se subordina a los conceptos de su sistema poético. Así, cuando leemos una afirmación como en "Portocarrero es frecuente la fijación de esas ciudades en un espacio de lejanía y en un tiempo reconstruido" [figura 16] (LEZAMA, 1994a, p. 227), tenemos una tesis sobre la obra de este pintor y un planteamiento propio del sistema poético lezamiano, es decir, la imagen. Una subordinación en la que estas formulaciones organizan un constante contrapunto o diálogo entre el carácter de la obra artística de René Portocarrero con los plásticos antes mencionados y con otros como Cézanne, el Greco [figura 25], Goya ${ }^{52}$, Uccello, Van Gogh, Monet y Utrillo.

En suma, para comprender la organización del ensayo "Homenaje..." es necesario revisar los conceptos del sistema poético lezamiano, sobre todo, la idea de imagen. En consecuencia, buscamos un acercamiento entre esta noción y las manifestaciones críticas que la consideran como una representación emparentada con el aura como fenómeno de lo sagrado y cultual. Posteriormente, y a partir de la sentencia horaciana de ut pictura poesis, analizaremos el nexo entre estas dos artes a partir de la pareja Baudelaire-Delacroix, con el fin de establecer una posible poética visual lezamiana presente en "Homenaje..."; poética en la que retomaremos el concepto de ecfrasis.

\footnotetext{
${ }^{52}$ Por ejemplo, con Cézanne, el Greco y Goya, Lezama organiza la argumentación de modo que la metáfora y la sobrenaturaleza aparezcan como el eje de la comparación entre Portocarrero y los tres artistas. De esta manera, leemos en Lezama que en la obra del pintor caribeño "Tanto sus árboles como sus flores, dentro de la tradición cezanniana del no modelar, modular, están apoyadas en esas sustituciones, que forman su continuo entre el hálito y la energía cosmológica"(LEZAMA, 1994a, p. 230); o que en dos cuadros, "uno del Greco, otro de Goya, [se] explican mejor el crecimiento orgánico de la ciudad en la sobrenaturaleza, que es la manera también de Portocarrero" (LEZAMA, 1994a, p. 255).
} 


\subsubsection{Un sistema poético en una crítica de arte}

\subsubsection{La dialéctica de la imago}

Qualquer imagem mental tem a mobilidade do movimento do espírito.

Pierre Francastel. Imagem, visão e imaginação

Son numerosos los apartados de "Homenaje..." donde se menciona a la imagen. Desde el comienzo del ensayo hallamos un lazo entre la imago y la distancia, en la caracterización de la idea misma de paisaje y en el carácter de las obras de Iacopo Bellini. Con respecto al pintor italiano, Lezama señala que:

No es necesario que el pintor enlace esa región en sus cercanías, por el contrario, se expresa como un punto en la lejanía. Se ve que esas ruinas no nacieron en un dictado de la cercanía, sino en un movimiento de la imaginación que se detuvo en esas ruinas traídas por la mano alargada de la imagen (LEZAMA, 1994a, p. 226).

La imagen es enlazada así a una idea de lejanía que, a su vez, se relaciona con la pintura paisajística. En este sentido, la oposición a la cercanía, a lo conocido ya de antemano -la $\operatorname{casa}^{53}$-, parece uno de los rasgos de la imago, pero no el único. Una distancia que posibilita la aparición de categorías como landscape e inscape, las cuales se vinculan a movimientos de alejamiento y cercanía, respectivamente. Así, en palabras del poeta, leemos que:

En alguna página anterior sobre Portocarrero, habíamos hecho referencia a ese landscape, a ese paisaje establecido en la distancia para circulizar la tierra ganada por la imagen. Desde entonces, Portocarrero no sólo ha fortalecido esa presencia de la lejanía, sino que ha ganado una nueva dimensión, el inscape. Esa palabra, traída a la poesía inglesa por Manley Hopkins, expresa el secreto ontológico, la forma interna, en el extremo de toda configuración, es como la melodía que lleva el hecho realizado a volver sobre el sujeto para provocarle una epifanía (LEZAMA, 1994a, p. 228).

\footnotetext{
${ }^{53}$ La casa como lo conocido, y donde no es necesario el distanciamiento operado por la imagen, aparece en repetidas ocasiones en el ensayo. La primera vez en función de la idea misma de cercanía; posteriormente asociada a la idea de cubanía. En cuanto a esta última, Lezama escribe: "He ahí la manera esencial de su esclarecedora cubanía en la fortaleza de la casa como imagen" (LEZAMA, 1994a, p. 229). Además de la casa, hay otra imagen que remite tanto a una proximidad como a un estatismo: el árbol. Ambos, la casa y el árbol, se convierten en imágenes intercambiables de una estructura, de una fijeza e inmovilidad que se relacionan con el movimiento interno del inscape. De esta forma, "toda casa tiene su raíz en la forma interna, en el inscape, en la melodía que devuelve la penetración. En el centro de toda casa hay una estructura, un árbol, que convierte lo real en sacramental, lo sacramental en germinativo. El árbol en el centro de la casa logra un tiempo sin antecedentes ni consecuentes, un tiempo resguardado de su fragmentación en los anillos de la serpiente" (LEZAMA, 1994, p. 228).
} 
Más allá de las ideas de distancia y proximidad como opuestas dentro del surgimiento de la imagen, conviene pensar más bien en una relación dialéctica. En este sentido, vale la pena recordar que para la creación de una imagen, a partir de la metáfora, por ejemplo, existe un elemento conocido, próximo a nosotros, del cual se parte para crear un aspecto nuevo, distante, por la novedad. Así, más que oposiciones, encontramos diálogos, encuentros entre los pares lejanía-cercanía, casa-ciudad, landscape-inscape e interno-externo. Quizás, y con respecto a este carácter dialéctico, sea pertinente observar otras parejas de conceptos que reafirman este carácter dialógico de la imagen. De este modo, Pierre Francastel en Imagem, visão e imaginação asevera que:

Qualquer captação de imagem pela nossa visão, acarreta o desenvolvimento de uma actividade mental, orientada simultaneamente numa dupla direcção. Formada por elementos, a imagem toma um sentido logo que estabelecemos uma relação combinada entre os signos materiais: quando presupomos que esses elementos reflectem conjuntos vulgarmente interpretados, enquanto objectos por um determinado grupo de indivíduos, estamos no domínio das configurações, ou seja, do espaço. Por outro lado, a imagem também toma um sentido, quando consideramos que os elementos espaciais assim constituidos, só possuem realidade na medida em que reflectem conhecimentos e valores que a aprendizagem imediata dos sentidos é insuficiente para criar; estamos então no domínio da memória ou do imaginário, isto é, do tempo. Desta forma, o espaço-tempo não poderá ser reduzido a uma apreensão única, nem a uma oposição. Não há nenhuma forma de pensamento que seja divisível, e também não é, nunca, por acumulação, que os elementos fornecem os princípios da intelecção. As categorias de espaço e de tempo estão apoiadas, não em diferentes séries de factos exteriores, mas nas modalidades em que se manifesta a atividade global do espírito (FRANCASTEL, 1987, p.97).

Categorías como espacio y tiempo, o composición imagética y memoria, no se oponen sino que se conjugan. En la situación enunciada por Francastel, el elemento espacial, donde la imagen es vista desde lo material, se une con un componente inmaterial e intangible, como lo es la memoria o el imaginario. Lo mismo sucede, desde otro punto de vista, cuando se piensa en la imagen poética. De acuerdo con Marcel Raymond, en su texto De Baudelaire al surrealismo, la imagen combina un componente espiritual con uno proveniente del mundo físico. Así, encontramos que:

Esas imágenes, cuyos elementos se han tomado del polvo de lo sensible, no tienen la función de describir objetos exteriores; su papel consiste en prolongar, en restituir movimientos interiores. 'En ese estado de Ilusión dice Novalis- no es tanto el sujeto quien percibe los objetos, sino que, a la inversa, los objetos vienen a percibirse en el sujeto. Toda imagen se organiza secretamente en símbolo, las palabras dejan de ser signos para participar en las cosas mismas, en las realidades psíquicas que evocan' (RAYMOND, 1960, p. 12). 
Debemos resaltar aquí una situación que destacan tanto Raymond como Francastel: la idea de que la imagen no cuenta con un referente exacto en la realidad. Esta observación es importante porque nos libera de un realismo achatado en el que la imagen, tanto la pictórica como la poética, representan una copia o un duplicado del mundo físico. En este sentido, trataremos siempre a las imágenes de arte -y estamos incluyendo a las de poesía- como entidades sin ninguna relación de identidad con objetos naturales existentes. Con las palabras de Francastel, las veremos como formas "dotadas de ciertas cualidades orgánicas que las transforman en objetos de imaginario, complejos, estructurados y capaces de fijar nuestra atención” (FRANCASTEL, 1987, p. 30).

\subsubsection{La imagen y la ficción}

La primera operación que Lezama realiza en el ensayo "Homenaje..." es la caracterización de la pintura de Portocarrero a partir de la imagen como un elemento que dialécticamente vincula lo "interno" o "cercano" -la casa- y lo "externo" o "lejano"-la ciudad. Este par de adjetivos le sirven para desarrollar una noción de procedimiento estético donde la imagen también comienza a asociarse a una idea de vacío creador o a una creación a partir de la ausencia y la lejanía ${ }^{54}$. No obstante, este no es el único proceso alrededor del cual se articula sino que se manifiestan otras maneras directamente relacionadas con las ideas expresadas en su concepción acerca del sistema poético. Una de ellas es el vínculo con las eras imaginarias, la otra es el lazo con conceptos del sistema poético como "naturaleza" y "sobrenaturaleza".

Antes de cualquier referencia a los elementos del sistema poético, Lezama Lima recurre a una imagen para mostrar su teoría sobre la creación pictórica. La escena incluye un episodio de caza donde se conjugan la memoria de una imagen con recreaciones de ésta a partir de sentidos como el oído y el tacto. Leemos:

\footnotetext{
${ }^{54}$ Otra percepción acerca de la cubanidad incluye no solamente la imagen estática y fija de la casa sino también el juego dialéctico con la ausencia o lejanía. En palabras de Lezama, este sería uno de los logros estéticos de Portocarrero con respecto a la inscripción en la tela de un carácter cubano. Al respecto señala: "He ahí la manera esencial de su esclarecedora cubanía en la fortaleza de la casa como imagen y en la dispersión por la muerte de los padres" (LEZAMA, 1994a, p. 229). Si por un lado existe una exaltación de las imágenes de la casa o el árbol en relación a lo próximo y lo inmutable, también es necesaria la inclusión de la distancia o "dispersión" a partir de la ausencia que genera siempre una posibilidad. De esta forma, no es gratuita la referencia en los ensayos sobre el sistema poético a un potens, a una posibilidad que surge a partir de una forma vacía.
} 
Entre el objeto y el pintor se establece una relación que de pronto oscila, se rompe y termina por desaparecer. El pintor tendrá que soldarlas con un grupo de imágenes que penetran en esa suspensión. Supongamos una venatoria medieval, el pintor ha fijado un cervatillo, y ya prepara la trampa de sus carbones. Sin correr el cervato hacia el bosque, el pintor siente que ya no está. Una relación de simpatía entre su visión y el fino animal ha desaparecido. Se ha establecido una suspensión. [...]. Pero en ese vacío el pintor oye la melodía, la serie de puntos en vibración que sigue a una desaparición; acaricia la forma de la ausencia de un animalejo cuyo cuerpo en su totalidad está hecho para responder al acecho con un alerta perpetuo, dictado por una red nerviosa, hecha para defenderse de lo furtivo, la serpiente que silba y salta, que diabólicamente lo persigue (LEZAMA, 1997, p. 229-230).

Hemos transcrito casi en su integridad este pasaje porque nos permite realizar dos operaciones. Por un lado, nos sirve para mostrar cómo procede la crítica de arte lezamiana, es decir, el modo proliferante de su escritura y su forma de acudir a las imágenes. Por otro, nos sirve para caracterizar el ensayo lezamiano a partir de un juego en el que no solamente se dan cita la erudición del autor sino, como ya lo hemos mencionado, la imagen poética ${ }^{55}$.

Quizá lo más importante es subrayar el carácter de ficción que encierra esta propuesta. Los datos sensibles que propone Lezama como acariciar (la cursiva es suya) una forma ausente solamente pueden existir desde la imagen, desde esa progresión metafórica hacia una Forma ideal, en suma, una invención (¿acaso es posible acariciar la forma de la ausencia?). De ahí que el rasgo más sobresaliente de la imago resida en esa facultad inventiva o ficcional pero no representa el único. Otro elemento que colabora en la creación es la memoria o el imaginario, como señalamos anteriormente con Francastel. Pero en el fragmento de Lezama percibimos que en la reconstrucción mnemónica de la imagen del cervatillo intervienen elementos musicales y no exclusivamente la visión y el tacto. Una imagen que de algún modo puede enlazarse con el soneto "Las correspondencias" de Baudelaire. Así, en el procedimiento de creación de ésta intervienen una visión interna y sensaciones táctiles y auditivas que, a nivel sensorial, serían completadas por los otros dos sentidos faltantes: el gusto y el olfato.

El carácter de ficción que atribuimos al concepto de imagen a partir de la participación de la lejanía, la ausencia o la suspensión en el fragmento sobre el episodio de caza del ciervo, nos

\footnotetext{
55 Otro ejemplo de esa escritura que teoriza sobre el quehacer del pintor se encuentra unas páginas más adelante cuando nuevamente Lezama elabora una correlación entre la visión y el tacto. La gran diferencia entre este fragmento y el otro que citábamos arriba es una mayor presencia de la imagen poética. Así, "La mano penetra en lo oscuro y los dedos matizan los instantes diversos en la urdimbre de la tela. Aún dueño de su visión, el pintor tiene en los dedos la conciencia palpatoria. Tiene los ojos para la luz y los ojos del ciego que reconocen en la súmula de los instantes, entregados por los dedos. Visión y visión en lo oscuro y las matizaciones de los dedos" (LEZAMA, 1994a, p. 232).
} 
proporciona también un posible diálogo con Francastel. Aunque se trate de enlazar la propuesta del ensayista con un crítico y teórico del arte, la caracterización de la imagen a partir de la fictio resulta importante para la comprensión de la crítica de arte lezamiana como un ejercicio entretejido con su concepción acerca del sistema poético. En palabras de Francastel:

Qualquer imagem é uma ficção, o que significa que associa obrigatoriamente elementos colhidos do real, com outros, retirados da memória, através da qual, em última análise, elementos afastados ou antigos -conhecidos através da experiência pessoal ou da experiência de outros homens- se tornam presentes e utilizáveis. Torna-se claro, assim, que uma das características fundamentais da imagem plástica consiste no fato de ela unificar elementos de origem diferentes, e que não possuem o mesmo caráter de realidade (FRANCASTEL, 1987, p.133-134).

Vemos que retorna el tema de la memoria ${ }^{56}$ para la elaboración de una imagen pictórica. La diferencia es que mientras Pierre Francastel, con un lenguaje claro que no apela a imágenes poéticas, especifica los dos elementos que intervienen en la creación de una imagen -la memoria y elementos del mundo real-, el poeta apela al relato para caracterizar la imagen desde la ficción ${ }^{57}$. No deja de ser curioso que en su explicación acerca del proceso de crear imágenes por parte del pintor intervenga una especie de narración, una escena ficticia de cacería que explica cómo la imago procede a partir del vacío. Pero no cualquier vacío, porque es uno que se sutura con el ejercicio de la memoria, una Mnemósine (sic.) que involucra recuerdos de sus sentidos y que le permite reconstruir ese ciervo, ese animal del mundo objetivo que no representa una mera copia de aquél del mundo real e inmediato.

\footnotetext{
${ }^{56}$ La memoria es un tema clave en la elaboración teórica lezamiana. En el primer capítulo la mencionamos en relación a la crítica y a la práctica de la lectura a partir del ensayo "Julián del Casal”. Ahora, en este apartado, la convertimos en el motor creativo de la imago a partir del ejemplo dado por el poeta cubano. No obstante, debemos aclarar que la remembranza no es el único eje. También habría un importante componente de azar evidente en el momento en que el pintor "oye la melodía [...] y acaricia la forma de la ausencia". Una coincidencia que nos recuerda el famoso episodio de la magdalena en En busca del tiempo perdido de Proust. Una hipótesis que enlaza la idea de imagen a la de aura benjaminiana.

${ }^{57}$ Otra forma de ver la relación de la imagen con la ficción la encontramos en el poeta francés Yves Bonnefoy. Según él, "La Imagen es ciertamente la mentira, por más sincero que sea su artífice" o "Es un infinito soñado dentro de la misma finitud de las cosas" (BONNEFOY, 2007, p.29). De este modo, su posición parece diametralmente opuesta a la de Lezama, en la medida en que valora positivamente la idea de presencia en detrimento del mundo-imagen. Para él, no es que este último posea únicamente un valor negativo sino que es necesaria la presencia, es decir, "una vivencia real en la imagen" (SÁNCHEZ-RAMÓN, 2005, p. 47). A pesar de esta diferencia, entre otras, nos llamó bastante la atención este autor porque escribe crítica de arte sobre pintores y escultores europeos como Alberto Giacometti, Aníbal Carracci o Caravaggio.
} 
2.5.2.3 ¿Un diálogo torcido? Reflexiones acerca de la imagen en José Lezama Lima y Pierre Francastel y del aura en Walter Benjamin y Georges Didi-Huberman

Aunque el poeta y ensayista cubano no abre su corpus de obras plásticas hacia las obras artísticas internacionales, ni busque "instaurar una teoría abarcadora acerca de la obra estética" ${ }^{58}$, no por ello es menos cierto que sus planteamientos pueden integrarse a otras corrientes del pensamiento sobre la expresión artística. Así, en las siguientes páginas entablaremos un diálogo entre él y dos teóricos y críticos de arte como Pierre Francastel y Georges Didi-Huberman. El propósito de este encuentro es una lectura abarcadora acerca de la reflexión sobre la imagen plástica, que nos permita observar las continuidades y las rupturas entre una propuesta de crítica de arte cuyo punto inicial es la poética del escritor cubano, y los planteamientos de dos críticos de profesión que también se aproximaron a manifestaciones como la literatura o el cine.

Con Francastel y su texto Imagem, visão e imaginação (publicado en 1983 con el título L'image, la vision et l'imagination), queremos destacar la propuesta ya señalada de la imagen como ficción y la conciencia de que, a partir de la obra de Cézanne y de Gauguin ${ }^{59}$, la pintura se desliga de la idea de producir objetos cuyo valor reside en la semejanza con los del mundo físico y se centra en la producción de piezas estéticas. En palabras de este crítico, "através de Cézanne -e de Gauguin-, a pintura tornou-se capaz de construir sistematicamente objectos análogos, e já não parecidos, aos da experiência sensível” (FRANCASTEL, 1987, p. 70). No podemos olvidar que lo que se destaca aquí es la idea de la autonomía del objeto artístico frente a la mera representación del mundo físico. Una rasgo de la creación plástica que Francastel defenderá a lo largo de su texto.

Con respecto a Georges Didi-Huberman, haremos dos operaciones. Por un lado entablaremos contacto con su idea sobre la imagen en relación al vacío y a la pérdida; por otro, trabajaremos la idea de imagen y aura, un planteamiento que Didi-Huberman desarrolla

\footnotetext{
${ }^{58}$ Decimos que no "abre su corpus a obras artísticas internacionales" porque no constituyen el centro de sus textos, aunque las mencione. Por otra parte, colocamos el "instaurar una teoría abarcadora acerca de la obra estética" entre comillas porque, como veremos posteriormente, nuestra tesis principal es que el José Lezama Lima propone, de forma implícita, una teoría sobre el objeto estético a partir de su concepción de la imagen. Así, subrayamos ese carácter "implícito", en la medida en que él nunca escribió un libro enteramente dedicado a este tema. De ahí que las compilaciones realizadas por Leonel Capote y Roberto Prats Sariol resulten tan valiosas para nosotros.

${ }^{59}$ No queremos decir que Lezama haya leído a Francastel o que siga a ciegas su planteamiento estético. Lo que está en juego aquí es la idea de la autonomía de la obra de arte, en el sentido que ésta no hace referencia a nada en el mundo real.
} 
a partir de Walter Benjamin, y en el que nos aproximaremos directamente tanto a su propuesta, como a los textos del filósofo alemán.

Uno de los rasgos más destacados de este crítico es su noción de que la imagen se vincula a una escisión, a una ruptura donde la noción de pérdida es "ineluctable". Una idea cuya negatividad no se presenta de forma absoluta o total sino bajo una forma oscilante: la del juego marino en la que el movimiento del agua, con sus avances y retrocesos, representa una figura fluctuante, cara también a la escritura lezamiana que, en el ensayo sobre Portocarrero, aparecía definida mediante la "suspensión", en el juego aparición-desaparición del ciervo.

La "ineluctable escisión de lo visible" resulta así el título más apropiado, no solamente para su primer capítulo sino para las dos operaciones que Didi-Huberman realiza en su texto O que vemos, o que nos olha. En primer lugar, destaca una imagen literaria como la summa de su concepción crítica, ya que se trata de una expresión que proviene del Ulises de Joyce, más exactamente del momento en el que Stephen Dedalus observa el mar y recuerda a su madre difunta. Una escena que, en sus palabras, ofrece "em sua precisão, todos os componentes teóricos que fazem de um simples plano ótico, que vemos, uma potência visual que nos olha na medida mesmo em que põe em ação o jogo anadiômeno, rítmico, da superfície e do fundo, do fluxo e do refluxo" (DIDI-HUBERMAN, 1998, p. 33). En segundo lugar, le permite caracterizar el fenómeno de la imagen visible, como una situación donde resulta inevitable un proceso de ruptura, de pérdida, un evento de angustia y un encuentro con el ser-ahí heideggeriano. De lo que se deriva que esa "modalidad" de lo visible, como inevitable o "ineluctable", comporte un encuentro con el "aura" de una obra y con el poder de "su" mirada. Es claro que la idea que rige el texto de Didi-Huberman es la de la obra de arte como objeto aurático que nos interpela porque nos mira, pero más que una mirada directa sobre nosotros, es la contemplación que la obra permite sobre nosotros mismos, sobre nuestra experiencia y nuestra memoria. De este modo, el mejor ejemplo proporcionado es la contemplación de una tumba. Según afirma:

Assim, diante da tumba, eu mesmo tombo, caio na angústia - a saber, esse "modo fundamental do sentimento de toda situação" -, essa "revelação privilegiada do ser-aí", de que falava Heidegger [...]. É a angústia de olhar o fundo -o lugar- do que me olha, a angústia de ser lançado à questão de saber (na verdade de não saber) o que vem a ser meu próprio corpo, entre sua capacidade de fazer volume e sua capacidade de se oferecer ao vazio, de se abrir (DIDI-HUBERMAN, 1998, p. 38). 
El poder de la imagen aparece en esta capacidad, la de una mirada en la que la obra -en este caso, tumba- obliga al espectador a mirar el fondo, a mirarse a sí mismo en una operación que lo disloca, que lo lleva a una reflexión y a una sensación de angustia frente a la muerte. También es una característica de algo que une en una misma figura lo lleno y lo vacío, es decir, la tumba como obra artística susceptible de observación simboliza, al mismo tiempo, un elemento que simplemente es (la piedra tallada sobre una lápida con la figura de alguien importante) y una situación o un concepto subyacente que, aunque implícito, no por ello deja de ser inquietante: la muerte, como vacío, como ausencia de vida en esa forma corporal. Sobresale en la argumentación de Didi-Huberman que no todas las piezas estéticas conjugan esta duplicidad, esta cualidad de trascender la forma hacia un concepto que puede resultar perturbador, y entre ellas destaca algunas producciones minimalistas ${ }^{60}$. Igualmente, y como se trata de una perspectiva no centrada exclusivamente en la obra estética, su mirada también incluye la posibilidad de que ésta no sea aurática o que el mismo espectador se rehúse a percibir este carácter y se convierta en lo que él denomina "el hombre de la tautología". Un tipo de espectador que solamente ve el objeto en su pura materialidad, sin percibir su aura.

No obstante, la idea de aura en un objeto de arte no se vincula únicamente a su capacidad de invocar una pérdida, de señalar un vacío sino que involucra una "dupla distância pictórica". Para Didi-Huberman, el aura es la relación de esas dos distancias que rodean una obra artística: por un lado, tenemos un objeto que en apariencia podemos "manipular", en el sentido en el que nos apropiamos de él para clasificarlo y hacerlo entrar dentro de una tradición con otros objetos ya conocidos, y por otro, no tenemos su lugar original, el contexto de su nacimiento. $\mathrm{Al}$ respecto sus palabras son esclarecedoras:

[...] é claro que fomos obrigados para "ter" o objeto, a virar pelo avesso o solo originário desse objeto, seu lugar agora aberto, visível, mas desfigurado

\footnotetext{
${ }^{60}$ Autores canónicos de la historia y de la crítica de arte como Giulio Carlo Argan señalan que corrientes como el arte conceptual o el hiperrealismo "assinalam o ponto limite da redução da arte a pura fenomenalidade". Estas corrientes, vistas en un ensayo escrito en 1984 como las más recientes, representan para este crítico y teórico italiano los dos extremos de un arte que, reducido a la mera objetualidad, propugna "a teoria sem prática" (el conceptualismo) y "a prática sem teoria" (el hiperrealismo) (ARGAN, 1988, p. 88-89). En ambos casos, el autor destaca la idea de que estas expresiones no representan el concepto de arte como valor y, en consecuencia, de acuerdo a nuestra argumentación, no constituyen en absoluto un arte aurático. En cambio, la posición de Didi-Huberman, en su ensayo de 1999, es más matizada cuando afirma que en la obra de algunos minimalistas existe la presencia de un aura o imagen. Así parece señalarlo cuando dice, en una nota de pie de página, "repetimos que nada disto constitui uma prerrogativa específica do minimalismo [su ausencia de imagen-aura]: ele é apenas uma forma exemplar. A dupla distancia verifica-se tanto nos mais sutis desenhos murais de Sol LeWitt quanto nas esculturas de Richard Serra" (DIDI-HUBERMAN, 1998, p. 168).
} 
pelo fato mesmo de pôr-se a descoberto: temos de fato o objeto, o documento - mas seu contexto, seu lugar de existência e possibilidade, não o temos como tal. Jamais o tivemos, jamais o teremos (DIDI-HUBERMAN, 1998, p. 176).

Vemos nuevamente este carácter de pérdida enlazado a la idea de imagen y de aura. De este modo, y para este crítico, la imagen auténtica es una representación mental o la imagen de un cuadro y una noción dialéctica y crítica que se alía a un discurso estético, crítico e histórico. Como discurso estético, Didi-Huberman piensa en el carácter de la imagen pictórica o escultórica, en su capacidad de remitir a otras realidades más allá de su materialidad; como discurso crítico reflexiona sobre la propuesta de Baudelaire, quien crea una forma poética imbuida de un trazo crítico que "transforma e inquieta os campos discursivos circundantes" (DIDI-HUBERMAN, 1998, p. 168); como discurso histórico, analiza el encuentro entre una imagen del pasado y el presente para observar cómo es la lectura y representación de ese pasado.

Es obvia la deuda de Georges Didi-Huberman con Walter Benjamin. Así lo reconoce en varias oportunidades y, sobre todo, cuando teoriza acerca de los rasgos de la imagen auténtica como una imagen dialéctica y crítica. Al igual que Benjamin, Didi-Huberman propone ampliar la noción de imagen más allá de la expresión plástica y hacia otros constructos donde intervienen la lengua y el discurso. Es la operación que realiza, por ejemplo, cuando habla de la crítica de arte como una imagen dialéctica, y cita las palabras del filósofo sobre el quehacer del crítico como el encuentro de palabras que martillen lo real "com pequenas marteladas até que nele [o real] tenham gravado a imagen como numa chapa de cobre" (DIDI-HUBERMAN, 1998, p. 184), o cuando piensa y comparte el anhelo benjaminiano de un discurso histórico sobre las obras de arte como una conjunción del discurso histórico-objetivo sobre los objetos estéticos con un discurso subjetivo sobre los mismos (DIDI-HUBERMAN, 1998, p. 187). En todo caso, posteriormente retomaremos el pensamiento de Benjamin para reflexionar más detenidamente sobre su concepción de aura, ya sin el filtro de Didi-Huberman, al igual que volveremos a la reflexión de Lezama sobre la imagen.

Un primer acercamiento a la idea de la imagen para José Lezama Lima puede ser hallado en el Diccionario Vida y obra de José Lezama Lima de Iván González Cruz. En una de las entradas correspondientes leemos: "Y como la semejanza a una Forma esencial es infinita, paradojalmente, es la imagen el único testimonio de esa semejanza que así justifica su voracidad de Forma, su penetración, la única posible, en el reverso que se fija” (GONZÁLEZ 
CRUZ, 2000, p. 207). Una definición con ecos platónicos y católicos donde hallamos una "Forma esencial" que corresponde a una Imagen ideal -y también a Dios-, de la cual el mundo objetivo resulta en una mera derivación o un reflejo, y una imagen que, en el sentido lezamiano, funciona como testimonio de esa otra realidad superior e invisible. Desde este panorama, y en palabras de Irlemar Chiampi, la imagen resulta "la única realidad y la interposición que cubre la distancia entre esa Forma y la irrealidad de los objetos" (CHIAMPI, 1982, p. 30). Pese a la clara identificación entre la imagen y la realidad, que podemos corroborar con Lezama en otros fragmentos, resulta confusa la imprecisión entre los términos "imagen" y "metáfora", ya que ambos son definidos en relación a la semejanza. Un obstáculo para la comprensión que esta crítica resuelve de manera afortunada en su texto “Lezama Lima: la imagen posible". Desde su punto de vista:

La indistinción en el uso del término 'imagen' (ora significa 'metáfora' -el procedimiento de semejar-, ora la finalidad de las metáforas -constituir la Imago) es aquí a propósito. No es difícil deducir que Lezama alinea sus conceptos de poética por la doctrina platónica de las ideas, repasada por el discurso teológico de los filósofos cristianos medievales. La suprema meta del camino recorrido por las imágenes es Dios, que en este ensayo está referido por metáforas (el "anterior", la "Forma", el "reverso" [...]. De este modo, la imagen contiene el dibujo de la progresión de la semejanza en busca de la Forma esencial (CHIAMPI, 1982, p. 30).

La imagen es, entonces, un concepto de orden metafísico o "sobrenatural" en el que se conjugan los avances metafóricos que representan la semejanza con la "Forma", el "anterior" o el "reverso", vocablos que la autora resalta como referencias a Dios. Es importante destacar también que la imagen no debe ser confundida con la imaginación, un giro común debido a la proximidad entre ambas locuciones. De acuerdo con Lezama en su ensayo "La imagen histórica" de Las eras imaginarias:

Por una fácil paradoja en la aceptación que le damos a la imagen, es ésta totalmente opuesta a la imaginación. La imagen extrae del enigma una vislumbre, con cuyo rayo podemos penetrar, o al menos vivir en la espera de la resurrección. La imagen, en esta aceptación nuestra, pretende así reducir lo sobrenatural a los sentidos transfigurados del hombre. Lo natural potenciado hasta alcanzar más cercanía con lo irreal, devolver acrecidos los carismas recibidos en el verbo, por medio de una semejanza que entrañe un desmesurado acto de caridad (LEZAMA, 1971, p. 61).

Como podemos ver, el concepto de imagen resulta definitivo en lo que concierne al sistema poético y a nuestra tesis de una continuidad entre los planteamientos sobre la poesía y la crítica de arte. Asimismo presupone el fondo sobre el que se recorta constantemente la interpretación y los juicios del poeta y ensayista acerca de los artistas a los cuales se refiere. 
No solamente una vez sino muchas veces y en relación a diferentes piezas y creadores plásticos aparece este término que no debe confundirse con la obra o con el elemento puramente visual. De hecho, como veremos en las siguientes páginas, Lezama no concibe la imagen dentro de lo pictórico sino dentro de este horizonte que, aunque se emparente con la realidad $^{61}$, tiene ese trasfondo "sobrenatural", de creación donde la metáfora avanza hacia la semejanza con la "Forma". Una similitud construida mediante la analogía metafórica y nunca gracias a un concepto de mímesis. Así, siguiendo al propio autor en su ensayo "Las imágenes posibles", hallamos que:

Pero siempre en la imitación o semejanza habrá la raíz de una progresión imposible, pues en la semejanza se sabe que ni siquiera podemos parejar dos objetos analogados. Y que su ansia de seguir, de penetrar y destruir al objeto, marcha solo acompañada de la horrible vanidad de reproducir (LEZAMA, 1977, p. 156).

La importancia concedida al carácter de una analogía basada no en comparar objetos semejantes sino en lanzar puentes entre elementos disímiles, es fundamental para vislumbrar los rasgos que el escritor valora en los artistas cuya obra analiza y sobre los que construye su poesía. En ningún caso, encontraremos a un Lezama que pondere un naturalismo mimético en términos positivos. De hecho, el primer juicio sobre Portocarrero valora una idea de distancia, donde no interviene una idea de copia sino de analogía de elementos heterogéneos alejados temporal y espacialmente. Así:

En Portocarrero es frecuente la fijación de esas ciudades en un espacio de lejanía y en un tiempo reconstruido. Lo mismo lo encontramos en Ouro Preto en las encaladas iglesias hechas por el Aleijadinho; en el ala de San Luis, entre medievales techos arcillosos y chimeneas cuyo humo revela la sobremesa dilatada: en la Bagdad de Harum Al Raschid, recibiendo incesantemente a los mercaderes que traen los prodigios. El barroco americano, la iglesia bizantina, la liturgia cismática griega, el castillo medieval, está siempre en la lejanía de su visión (LEZAMA, 1994a, p. 227).

Es verdad que en "Homenaje..." Lezama no se refiere puntualmente a la reproducción. No obstante, la misma caracterización de las metrópolis de Portocarrero, en términos de confluencia de diferentes elementos, difiere de lo que consideramos como los rasgos de la copia. Entre las características de esta última encontramos, de acuerdo a Benjamin, un ansia

\footnotetext{
${ }^{61}$ En una de las entradas del diccionario de Iván González Cruz encontramos las siguientes palabras de Lezama: "Yo no creo que haya que establecer un dualismo entre imagen y realidad. La imagen es la misma realidad y lo que alcanzamos de la realidad es la imagen. Si no fuera por eso, el mundo sería intocable e indefinible y una especie de ceguera tenebrosa rodearía la naturaleza, haciéndola imposible a su penetración al hombre" (GONZÁLEZ CRUZ, 2000, p. 210).
} 
de posesión y una marcada inmediatez ${ }^{62}$ que no tendrían ninguna relación con la manera en que este pintor construye sus ciudades. A pesar de que este no es un ejemplo específico sobre la mímesis o la copia en la obra del artista, sirve a modo de paradigma de lo que Lezama considera como uno de los valores en la obra de los plásticos que examina. En este caso, se trata del valor de la "lejanía" o de la creación de la urbe desde la imagen.

Una tentativa de aproximación entre la noción lezamiana de imagen y la noción de aura de acuerdo a los postulados de Benjamin a esta altura puede ser cuestionable. Primero, porque no hay una relación directa o explícita entre ambas y, segundo, porque la forma como Lezama enlaza el término "imagen" con la constelación de ideas y conceptos que conforman su "sistema poético" no guarda relación con el contexto de generación del término "aura" los textos que vamos a analizar. Pese a estas diferencias, queremos señalar la existencia de una posible convergencia entre el poeta y el filósofo alemán, a partir de dos textos del segundo -"Sobre alguns temas em Baudelaire" y "A obra de arte na era da sua reprodutibilidade técnica"- y según la conceptualización sobre la imagen lezamiana que desarrollamos en las páginas y párrafos anteriores. Vale la pena señalar desde ya que aprovecharemos este vínculo inicial para desarrollar un poco más el punto de vista de DidiHuberman sobre la imagen. Esta última mirada resulta muy importante para entender el eje de una crítica de arte que parece detenerse específicamente en un tipo de obras de artes visuales.

Los dos primeros rasgos que nos llaman la atención son la lejanía y la invisibilidad. En cuanto a la distancia, Benjamin afirma en "Sobre alguns temas em Baudelaire", ensayo publicado en 1939, que:

Perceber a aura de uma coisa significa investi-la do poder de revidar o olhar. Os achados da mémoire involontaire confirmam isso (e não se repetem, de resto: escapam da lembrança, que procura incorporá-los. Com isto elas corroboram um conceito de aura, que a concebe como "o fenômeno irrepetível de uma distância" (BENJAMIN, 2000, p. 140).

A partir de su análisis sobre Baudelaire, Benjamin percibe la distancia de acuerdo a la idea de experiencia y de memoria involuntaria que el mismo autor observa en relación a la

\footnotetext{
${ }^{62}$ Pensamos en el ensayo "A obra de arte na era de sua reprodutibilidade técnica", donde Benjamin señala la pérdida del aura gracias al fenómeno de masas, ya que "cada dia fica mais irresistível a necessidade de possuir o objeto, de tão perto quanto possível, na imagem, ou antes, na sua cópia, na sua reprodução" (BENJAMIN, 1996, p.170). Una inmediatez que colabora con la destrucción de la unicidad de la obra de arte.

63 Benjamin al acuñar el concepto de "aura" está pensando en el contexto de la modernidad con su "experiencia vivida" (erlebnis), que es inauténtica. La inautenticidad de la experiencia se debe a varias razones además de las citadas arriba. Entre ellas, la inmersión del hombre en la vida anónima y desarraigada de las grandes ciudades.
} 
obra de Proust. De acuerdo a esto, es la memoria involuntaria la que fijaría una experiencia auténtica o erfahrung que realmente resulta irrepetible, contraria a lo que los mecanismos de la modernidad -de acuerdo a Benjamin- realizan con la reproducción, la repetición y la fragmentación, situaciones que se vinculan con la memoria voluntaria. Desde esta perspectiva, el significado del aura de una cosa resulta un poder que nos mira, que nos devuelve nuestra mirada y nos brinda una experiencia auténtica, única, que no se repite y que no está mediada por la conciencia, por la voluntad. En este sentido, el apartamiento parece hacer referencia a dos situaciones: la irrepetibilidad y el carácter cultual del fenómeno aurático, trazo que Benjamin otorga a la imagen de devoción, la cual es "inacessível em sua esencia” (BENJAMIN, 2000, p. 140).

Este carácter ritual de la obra de arte aurática recibe una mayor profundización por parte de este autor en su texto "A obra de arte na era da sua reprodutibilidade técnica", publicado inicialmente y de forma abreviada en 1936. Según él:

As mais antigas obras de arte, como sabemos, surgiram a serviço de um ritual, inicialmente mágico e depois religioso. O que é de importância decisiva é que esse modo de ser aurático da obra de arte nunca se destaca completamente de sua função ritual. Em outras palavras: o valor único da obra de arte "autêntica" tem sempre um fundamento teológico, por mais remoto que seja: ele pode ser reconhecido, como ritual secularizado, mesmo nas formas mais profanas do culto do Belo (BENJAMIN, 1996, p. 171).

Queda claro que para Benjamin la obra de arte aurática posee este carácter religioso asociado al culto presente desde las sociedades primitivas, lo cual permite una asociación con el carácter divino que Lezama algunas veces lee en la imagen. Quizás sea éste el único rasgo en común a ambos y que, en consecuencia, conduce al carácter de inaccesibilidad antes mencionado, que el poeta, ensayista y narrador interpreta de otra forma. Para el cubano la imagen a veces se identifica con Dios o puede leerse en ocasiones como el verdadero ser de las cosas, de la cual recibimos una imagen-reflejo. Una posibilidad que, como hemos mencionado, se enlaza con la teoría platónica. En todo caso, si volvemos a Benjamin, debemos pensar que su idea de aura se asocia a la memoria involuntaria, a la experiencia auténtica, a la distancia, a la irrepetibilidad y a una "función ritual". Rasgos, todos ellos, que se conectan con la experiencia producto de la visión de una obra artística aurática y que no se relacionan en absoluto con la idea de imagen de Lezama sino, más bien, con los planteamientos de Didi-Huberman que veremos a continuación. 
El trabajo con estos dos autores -con Benjamin y con Didi-Huberman- se justifica porque ambos nos permiten configurar una convergencia: una noción de "valor" de la obra de arte que sirve como marco de la crítica lezamiana. Con esta idea pensamos en lo que Lezama pondera positivamente en la obra de arte, mediante sus juicios en los que siempre involucra su concepción personal sobre la poesía, su particular mirada acerca de la historia y de la tradición en el arte y hasta de sus digresiones. Pero también esta idea de "valor" nos hace pensar en lo que el poeta cubano rechaza, en lo que queda por fuera de sus preferencias y de su atención. De todas formas, debemos tener como horizonte que la mayoría de artistas plásticos que son considerados en sus textos son cubanos y pertenecen a su círculo de amigos.

En uno de los capítulos de $O$ que vemos, o que nos olha, Georges Didi-Huberman trabaja el concepto de imagen dialéctica y crítica benjaminiana como el marco conceptual que le permite el análisis del trabajo artístico de Tony Smith y de Ad Reinhardt. Según sus palabras, este tipo de imagen (dialéctica y crítica son sinónimos) se caracteriza así:

Falar de imagens dialéticas é no mínimo lançar uma ponte entre a dupla distância dos sentidos (os sentidos sensoriais, o ótico e o tátil, no caso) e a dos sentidos (os sentidos semióticos, com seus equívocos, seus espaçamentos próprios) (DIDI-HUBERMAN, 2005, p. 169).

Esa doble distancia entre la comprensión sensorial y la semiótica presenta una relación de carácter originario que Didi-Huberman llama "aura". Un origen que puede explicarse de la siguiente manera:

A origem surge diante de nós como um sintoma. Ou seja, uma espécie de formação crítica que, por um lado, perturba o curso normal do rio (eis aí seu aspecto de catástrofe, no sentido morfológico do termo) e, por outro lado, faz ressurgir corpos esquecidos pelo rio ou pela geleira mais acima, corpos que ela "restitui", faz aparecer, torna visíveis de repente, mas momentaneamente: eis aí seu aspecto de choque e de formação, seu poder de morfogênese e de "novidade" sempre inacabada, sempre aberta, como diz tão bem Walter Benjamin. E nesse conjunto de imagens "em via de nascer", Benjamin não vê ainda senão ritmos e conflitos: ou seja, uma verdadeira dialética em obra $^{64}$ (DIDI-HUBERMAN, 2005, p. 171).

Este rasgo originario y de síntoma del "aura" es central porque es esa formación crítica, ese resurgir de un elemento que interrumpe el curso natural del acontecimiento y que nos lleva a cuestionarnos, lo que une este pasaje con lo que se había comentado anteriormente acerca de la imagen como una pérdida en el caso de la escena joyciana de Stephen Dedalus.

\footnotetext{
${ }^{64}$ En "Sobre alguns temas em Baudelaire", Benjamin se refiere también al aura como "as imagens que, sediadas na mémoire involontaire, tendem a se agrupar em torno de um objeto de percepção" (BENJAMIN, 2000, p. 137).
} 
Pero la semejanza no se detiene ahí. Recordemos que en el primer fragmento citado de Benjamin, "Perceber a aura de uma coisa significa investi-la do poder de revidar o olhar" (BENJAMIN, 2000, p.140), se halla el enunciado que resume toda la propuesta de DidiHuberman sobre la contemplación de las obras de arte y, a su vez, la noción de aura como un encuentro con una experiencia que nos desafía (como en el caso de la visión de la tumba) y que es auténtica. De esta manera, una imagen dialéctica o crítica, además de poseer el elemento aurático, también conduce a una elaboración mental. El objeto estético observado no es mera materia sino que suscita una actitud crítica. En las palabras de Didi-Huberman:

Assim teremos talvez uma chance de compreender melhor o que Benjamin queria dizer ao escrever que "somente as imagens dialéticas são imagens autênticas", e por que, nesse sentido, uma imagem autêntica deveria se apresentar como imagem crítica: uma imagem em crise, uma imagem que critica a imagem -capaz portanto de um efeito, de uma eficácia teóricos-e por isso uma imagem que critica nossas maneira de vê-la, na medida em que, ao nos olhar, ela nos obriga a olha-lá verdadeiramente" (DIDIHUBERMAN, 2005, p. 172).

La imagen aquí no se presenta como un engaño ni como ficción, a semejanza del famoso soneto de Sor Juana "Este que ves, engaño colorido" sino que conlleva una idea de valor asociada a su componente crítico. Si pensamos en la crítica de arte lezamiana, el trabajo de los artistas que el poeta analiza se enmarca justamente en esta noción. Así un René Portocarrero o un Mariano Rodríguez - por mencionar sólo un par-crean una obra artística que le permite a Lezama todo un aparato crítico relacionado con su visión de la poiesis, y también el elogio por sus cualidades plásticas. Ya que las obras de estos dos artistas se enmarcan en una visualidad donde la obra estética es concebida como una expresión única, sus creaciones pueden sujetarse a la noción de aura benjamiana. El encuentro visual con ellas no es con su materialidad pero sí con lo que ellas esconden y que conduce a la reflexión. En suma, su crítica sobre artes visuales no suele tomar en cuenta obras que no se encuadren dentro de esta perspectiva aurática, lo cual también la reduce, en su gran mayoría, a una crítica de obras modernas pero no asociadas al arte no representativo. Claro, el pensar en obras plásticas vinculadas a esta clase de corrientes admite la presencia de cubanos como Antonia Eiriz (1929-1995), Dolores Soldevilla (1901-1971)y Salvador Corratgé (1928); o los representantes del arte neoconcreto de los años 60: los brasileños Lygia Clark (1920-1988) y Hélio Oiticica $(1937-180)^{65}$. Un análisis que involucra herramientas distintas a las empleadas en su crítica

\footnotetext{
${ }^{65}$ Escogimos estos cinco artistas porque su obra se enmarca en los años sesenta, época en que el poeta y narrador cubano debió tener alguna noticia de ellos (por lo menos de los tres cubanos). De este modo
} 
poética y que acarrearía un análisis de una fracción de obras artísticas muy diferente de las obras del siglo XX escogidas por él. No obstante, si pensamos en la importancia de la crítica de arte realizada por poetas, esta segmentación y esta atención dada solamente a una pequeña porción de obras y de autores puede realmente representar una dificultad y una falencia. Un aspecto que analizaremos con más detenimiento en el apartado titulado "La escisión en la visión: la copia, la crítica y el arte contemporáneo"

\subsection{LEZAMA, BAUDELAIRE Y DELACROIX}

Que retornemos a Baudelaire tiene una función estratégica, ya que nos permite una mayor comprensión de la crítica de arte de José Lezama Lima y posibilita una hipótesis de lectura más abarcadora de su escritura y, tal vez, de la literatura moderna en general. El hecho de ser un poeta que escribió crítica no solamente sobre la poesía sino sobre la música y la pintura de su tiempo, lo coloca en una posición privilegiada para nuestro caso de estudio porque nos autoriza a comprender los comienzos de una crítica poética y el carácter de una modernidad cambiante que entronizaba a la burguesía y al individualismo. En nuestra opinión, Baudelaire no es exclusivamente la figura capital de la poesía moderna -posición determinada ya por la crítica- sino que su poesía y sus escritos críticos manifiestan una voluntad de acercamiento y hasta de ejecución de los principios pictóricos. Este empeño suyo es el que nos interesa analizar ahora con el fin de observar las marcas dejadas en herederos suyos como Lezama.

En el prefacio a Las flores del mal, Baudelaire señala el vínculo entre la poesía y la pintura de la siguiente manera:

Que la frase poética pueda imitar (y por lo tanto rozar el arte musical y las ciencias matemáticas) la línea horizontal, la fuerte línea ascendente, la fuerte línea descendente; que pueda escalar una pendiente hacia el cielo, sin perder el aliento, o descender perpendicularmente hacia el infierno con la misma rapidez de su peso, que puede seguir la espiral, describir la parábola, o el zigzag en una serie de ángulos sobrepuestos.

Esta poesía está conectada a las artes de la pintura, la cocina y la cosmética por la posibilidad de expresar cualquier sensación de dulzura o amargura, de beatitud o horror, por el emparejamiento de tal o cual sustantivo con tal o cual adjetivo, análogo o contrario (BAUDELAIRE, 1961, p. 86).

encontramos a creadores como Antonia Eiriz (quien en 1968 realiza la obra "Una tribuna para la paz democrática" [figura 18], la cual resulta la primera instalación hecha en Cuba), Dolores Soldevilla [figura 19] y Salvador Corratgé [figura 20] (artistas vinculados al abstraccionismo geométrico y al cinetismo). En cuanto a los brasileños, a pesar de su importancia como pioneros de expresiones artísticas que no obedecen exactamente a un rótulo, no podemos saber si Lezama supo acerca de ellos. 
Sobresalen en este fragmento las características espaciales y hasta geométricas que la poesía puede imitar pero se destaca, sobre todo, la afirmación de un vínculo del arte poético con la pintura, la cocina y los cosméticos. Un lazo que recuerda sobremanera a El pintor de la vida moderna y al planteamiento sobre el carácter artificial del maquillaje; un rasgo que, lejos de ser negativo, se asocia a la virtud, al verdadero poder creativo y constructivo del ser humano, que recurre al artificio para reformar a la naturaleza, así como las mujeres usan el maquillaje para resaltar sus cualidades femeninas. Recordemos las palabras de Baudelaire:

La virtud, al contrario, es artificial, sobrenatural, desde que necesitó, en todos los tiempos y en todas las naciones, de los dioses y de los profetas para enseñarle a la humanidad animalizada, lo que el hombre, solo, había sido impotente para descubrir [...]. La mujer está en su derecho, e inclusive ella lleva a cabo una especie de deber dedicándose a aparecer mágica y sobrenatural; es necesario que ella asombre, que ella encante, ídolo, ella debe adorarse para ser adorada (BAUDELAIRE, 1992, 375-376) ${ }^{66}$.

El carácter artificial como un elemento mediato, fabricado y positivo contrario a la naturaleza con su expresión inmediata de instinto y apetito, es uno de los valores que el poeta francés resalta como adecuado para definir lo que, desde su concepción, debe ser el arte moderno. En suma, una expresión estética que se apoya en lo actual, en lo cambiante y en lo mudable, y que acentúa a las figuras que se distinguen de la multitud como el flâneur o el dandy, ambas dotadas de una artificialidad que las hace diferenciarse y nunca parecer hombres "vulgares", gracias a la "superioridad aristocrática de su espíritu" (BAUDELAIRE, 1992, p. 370). No podemos dejar de lado esta peculiaridad espiritual del dandy destacada por él mismo. Aunque es verdad que este personaje se presenta bajo el artificio de su elegancia material (la ropa y el cuidado con su cuerpo), no por ello abandona una especie de “espiritualismo y de estoicismo"67 (BAUDELAIRE, 1992, p. 370).

\footnotetext{
${ }^{66}$ En el original en francés tenemos: "La vertu, au contraire, est artificielle, surnaturelle, puisqu'il a fallu, dans tous les temps et chez toutes les nations, des dieux et des prophètes pour l'enseigner à l'humanité animalisée, et que l'homme, seul, eût été impuissant à la découvrir [...]. La femme est bien dans son droit, et même elle accomplit une espèce de devoir en s'appliquant à paraître magique et surnaturelle; il faut qu'elle étonne, qu'elle charme; idole, elle doit se dorer pour être adorée" (BAUDELAIRE, 1992, p. 375-376).

${ }^{67}$ Recordemos el ensayo de Lezama sobre Julián del Casal, donde precisamente aparece la misma valoración de Baudelaire sobre la insensibilidad del dandy, junto con la apreciación positiva de su desdén hacia las cosas materiales, lo cual le proporciona un aura antropocéntrica. Lo importante aquí es ver cómo a partir de ese dandismo, que el poeta cubano rodea de valoraciones positivas, se revela la noción de lo "natural excesivo". Nosotros entendemos esta idea desde el artificio, es decir, de la reforma a la naturaleza a partir del arte, de la construcción metafórica, lo que representa un exceso en sí, una "sobrenaturaleza". El mismo Lezama reconoce que es ese "natural excesivo" el rasgo fundador de la poesía contemporánea.
} 
Más allá de la idea de artificio vista anteriormente, conviene ahora subrayar otro elemento fundamental de la estética del poeta: las correspondencias y la búsqueda de una totalidad. Aunque parezca un tema trabajado hasta la saciedad por la crítica, resulta conveniente reflexionar nuevamente sobre él porque es una noción que subyace a la crítica de arte de Lezama. El fragmento del cervatillo ilustra esta idea de proceso artístico donde intervienen las sensaciones, sin una prevalencia del que suponemos es el sentido primordial a la hora de elaborar un cuadro: la vista. Recordémoslo:

Entre el objeto y el pintor se establece una relación que de pronto oscila, se rompe y termina por desaparecer. El pintor tendrá que soldarlas con un grupo de imágenes que penetran en esa suspensión. Supongamos una venatoria medieval, el pintor ha fijado un cervatillo, y ya prepara la trampa de sus carbones. Sin correr el cervato hacia el bosque, el pintor siente que ya no está. Una relación de simpatía entre su visión y el fino animal ha desaparecido. Se ha establecido una suspensión. [...]. Pero en ese vacío el pintor oye la melodía, la serie de puntos en vibración que sigue a una desaparición; acaricia la forma de la ausencia de un animalejo cuyo cuerpo en su totalidad está hecho para responder al acecho con un alerta perpetuo, dictado por una red nerviosa, hecha para defenderse de lo furtivo, la serpiente que silba y salta, que diabólicamente lo persigue (LEZAMA, 1997, p. 229-230).

El concepto de las correspondencias aparece vinculado a la idea de la obra de arte como símbolo que aspira a una totalidad, donde no habría fronteras entre la poesía y sus artes hermanas como la pintura y la música. No obstante, y de acuerdo a The metaphor of painting. Essays on Baudelaire, Ruskin, Proust and Pater de Lee McKay Jhonson, cabe un destacado papel a la búsqueda y a la realización de efectos gráficos en la poesía. Un énfasis que, según él, es poco estudiado por la mayor parte de los críticos, quienes otorgan un mayor énfasis al elemento musical en el poema simbolista ${ }^{68}$.

De acuerdo a Jhonson:

El segundo aspecto está relacionado con los valores simbolistas de multiplicidad, relatividad y reciprocidad: si el significado de uma obra de arte como símbolo debe ser percibida como una totalidad, entonces la literatura debe de alguna manera poder aproximarse al efecto de simultaneidad de la pintura, en el que todas las partes del óleo son vistas juntas y en relación de una sola vez [...]. Pero durante el periodo Simbolista, los escritores desafiaron a los pintores, y crearon una variedad de equivalentes literarios para la estructura de la pintura, formas organizadas

\footnotetext{
${ }^{68}$ "Symbolist writers often underline their interest in the relationships between the arts, but most critics who write about Symbolism as a movement tend to single out the analogy to music as predominant" (JHONSON, 1980, p. 21).
} 
alrededor del ideal de totalidad y diseñadas para operar con una simultaneidad teórica (JHONSON, 1980, p. 2). ${ }^{69}$

Nuevamente volvemos al inicio de nuestro texto cuando, al referirnos a la "Filosofía de la composición" de Poe y al texto "Two visual excursions" de Joshua Taylor, encontrábamos la exigencia de un lenguaje que impactara al lector, que fuese poético y sugerente. Una impresión que junto a las correspondencias como simultaneidad en busca de una expresión total nos hace volver al pasaje lezamiano del ciervo y en su índole evocadora de múltiples sentidos. Uno de ellos, y el más obvio, es el componente sensorial que deja de lado, precisamente, el sentido de la visión; una omisión intencional que favorece una visualidad interna, invisible e intangible, construida a partir de otras sensaciones, supresión ésta que nos lleva a pensar en el discurso católico, más exactamente en el de San Pablo, cuando afirma que "no ponemos nuestros ojos en las cosas visibles sino en las invisibles; pues las cosas visibles son pasajeras, mas la invisibles son eternas (San Pablo, Corintios 4:18). El otro es la continuidad entre el objeto del cuadro y el pintor mediante la imagen de la forja como el instrumento que permite "soldar" un conjunto de imágenes. No obstante, se trata de una fragua subordinada a la configuración de imágenes mentales y no ópticas, porque ¿cómo se retrata la sensación de ausencia del cervatillo? ¿Cómo se dibuja la suspensión en la que el artista oye la melodía? La aseveración de Jhonson acerca del desafío de los poetas simbolistas a los pintores es absolutamente aplicable a Lezama, en la medida en que éste explota la carnalidad del lenguaje sin invocar lo pictórico. Una dimensión que excede la mirada y explora la sensorialidad a través de la imaginación.

Ahora bien, a partir de la lectura de Painting and Poetry: Form, Metaphor, and the Language of Literature de Franklin Rogers comenzamos a reflexionar en la idea de un pensamiento visual puro como parte estructural de la obra lezamiana ${ }^{70}$. Una visualidad que permite la comprensión de sus metáforas y que atraviesa la totalidad de su escritura (cuento,

\footnotetext{
${ }^{69}$ En el texto en inglés hallamos: "The second aspect is related to the Symbolist values of multiplicity, relativity and reciprocity: if the meaning of a work of art as Symbol must be perceived as a totality, then literature must somehow manage to approximate the simultaneous effect of painting, in which all parts of the canvas are seen in relation together all at once [...]. But during the Symbolist period, writers challenged the painters, and created a variety of literary equivalents for the structure of a painting, forms which are organized around the ideal of totality and designed to operate with theoretical simultaneity" (JHONSON, 1980, p. 2).

70 La razón de esta probabilidad fue la contundencia de la frase: "La metáfora verbal solamente es comprensible a través de la metáfora visual” (ROGERS, 1985, p. 120). Una aserción que, siguiendo a este escritor, se sustenta en una anécdota: en una discusión sobre la metáfora, Picasso es interrogado sobre la idea de la conversión de un cisne en escorpión y su respuesta no deja lugar a dudas cuando bosqueja detrás de un sobre la imagen unificada de ambos animales.
} 
novela, ensayo y poesía). En otras palabras, una hipótesis que nos permitirá incluir al autor en una estela de poetas-pintores como Baudelaire y que nos concederá la oportunidad de observarlo también en relación al vínculo entre el autor de Las flores del mal y Delacroix.

Si asumimos que el poder visual de la imagen es el primer paso hacia la comprensión de esa nueva realidad propuesta por la metáfora, no nos deben extrañar textos críticos como el de Elizabeth Abel. En él, esta autora propone una análisis minucioso del poema " $L$ 'invitation au voyage" de Baudelaire en términos de su valor pictórico. Así, esta crítica señala que su autor es un poeta-pintor que intenta en la poesía una visión pura y singular, un efecto propio de la pintura. Sin embargo, su proposición va más allá cuando se detiene también en las tentativas de Delacroix, ya que:

Ambos artistas están intentando sintetizar el movimiento con la forma, pero esta síntesis debe ser lograda en la poesía mediante el trabajo de subsumir las secuencias del lenguaje a una visión única, y en la pintura mediante el avivamiento de la forma espacial con el movimiento. Las dos artes son similares como conjunto y no en sus características individuales (ABEL, 1980, p. 52). ${ }^{71}$

Nos llama la atención este intercambio entre ambas artes y entre ambos artistas. Aunque el foco está en los dos creadores, el pintor busca la vitalidad del conjunto con una idea de movimiento donde intervienen los colores. No olvidemos que uno de los elementos que destacaba y admiraba Baudelaire con respecto a la pintura de Delacroix [figura 21], era el color y, precisamente, este es uno de los factores que observa Abel como puente entre las dos actividades y figuras ${ }^{72}$. En palabras de Abel sobre "L'invitation au voyage": "Estas relaciones de luces, olores, y sonidos que se expanden más allá de los objetos específicos combinadas en una armonía general, sugieren la analogía del uso del color de Delacroix para evadir las fronteras de los objetos y crear la armonía evocadora de la música" (ABEL, 1980, p. 57) ${ }^{73}$. Habría un diálogo completo entre ambos y no solamente un movimiento unidireccional, lo

\footnotetext{
${ }^{71}$ Both artists are attempting to synthesize movement with form, but this synthesis must be achieved in poetry by working to subsume sequential language to a single vision and in painting by enlivening the spatial form with movement. The two arts are alike as wholes and not in their individual features (ABEL, 1980, p. 52).

${ }^{72}$ Curiosamente estas mismas características de luz y color son bastante ponderadas por José Lezama Lima en las obras pictóricas que analiza. Así lo asevera Leonel Capote en su introducción a la compilación La visualidad infinita. De acuerdo con él, "en el plano formal el color y la luz fueron los dos elementos visuales que más llamaron su atención al estructurar una opinión sobre cualquier pintor" (CAPOTE, 1994, p. 37-38). Pero aquí también aparece la reciprocidad: la obra novelística y poética lezamiana estaría influencia por esos mismos elementos pictóricos. Siguiendo a Capote, "Esa unión del color y la luz, tan frecuente en sus versos, le identifican aún más con los motivos de los pintores del grupo" (CAPOTE, 1994, p. 41).

73 "These relationships of lights, smells, and sounds that expand beyond specific things to blend in a general harmony suggest the analogy to Delacroix's use of color to evade the boundaries of objects and create a harmony evocative of music" (ABEL, 1980, p. 57).
} 
cual nos hace pensar cómo Lezama construye también una poética de lo visual dentro de su propia crítica de arte. No buscamos exactamente un diálogo a la manera de Baudelaire y Delacroix, porque la aproximación crítica del escritor de la isla hacia la pintura de la segunda generación de artistas de la vanguardia cubana obedece más a sus propias concepciones acerca de la poesía. De ahí que encontremos, por ejemplo, algunas divergencias que trabajaremos en las próximas líneas.

A partir de esta etapa observaremos algunos obstáculos entre nuestros planteamientos y la forma como Lezama concibe la relación entre la poesía y la pintura, la imagen y su visualidad. Sin embargo, no serán los únicos caminos para analizar las perspectivas puestas en juego a la hora de abordar un tema como su crítica de arte a nivel formal y de contenido. También revisaremos nuevamente las ecfrasis que aparecen en "Homenaje..." porque nos interesa desmontar este mecanismo en la escritura crítica del cubano. No podemos olvidar que este concepto involucra las distintas formas en que una obra proveniente del mundo plástico es vertida en el lenguaje verbal, y resulta un dispositivo fundamental para entender un entramado crítico rico en asociaciones que sobrepasan las meras equivalencias y crean situaciones nuevas o metafóricas.

Una objeción importante a nuestra reflexión sobre el lazo entre las artes hermanas es la negación que ofrece Lezama a este vínculo. Así, en "Paralelos..." afirma que "el hecho de que Baudelaire se acercase a la obra de Ingres o de Delacroix, nos llevaría a rastrear y a negar la presencia de esos pintores en Las flores del mal" (LEZAMA, 1994, p. 68). Una negativa al nexo entre el pintor y el poeta que, en apariencia, parece rechazar la presencia de elementos pictóricos en los poemas. No obstante, pensamos que no es una refutación concluyente y sí un ejemplo de su dialéctica de aceptación-negación. Dada la dinámica del raciocinio lezamiano, consideramos que en este pasaje hay un reconocimiento de la presencia de esos artistas plásticos pero no en un nombrar directo y sí en uno implícito, velado. De ahí que podamos dar un paso más dentro del mismo ensayo y observar una subordinación en vez de una repulsa, ya que la poesía organiza la experiencia visual. De esta manera, "es la palabra poética la que ordena las condensaciones que diferencian la igual sutileza de un aire semejante" (LEZAMA, 1994, p. 69).

El restablecimiento de la relación entre la lírica y la pintura, a pesar del reparo de Lezama, favorece el atisbo de otro vínculo: la aparición de una rica visualidad en su palabra, un hecho que se sustenta en su escritura acerca de obras pictóricas o escultóricas y cuando en 
su poesía asoma una fuerza visual donde imperan el color y la luz. Nos referimos así a dos circunstancias: una signada por la ecfrasis y otra por la visualidad propia de la palabra poética. Para la primera, los ejemplos incluyen a La expresión americana con sus alusiones al Libro de horas [figura 15], a Brueghel y a Simone Martini o al inicio de "Paralelos..." con la descripción ecfrástica de los tapices de Zamora [figura 1], obras que el almirante Colón observa y que, en función del imaginario y la memoria, son transpuestos a la nueva realidad americana $^{74}$, entre muchos otros. En cuanto a la segunda, una pequeña muestra puede ser el poema "La prueba del jade"75, en el cual la sensación del frío de la piedra semipreciosa en el rostro de un "yo" protagonista se hace evidente mediante el uso de imágenes que incluyen el blanco, la escarcha, la transparencia del agua y del espejo, pero también gracias a elementos opuestos como el fuego. Una escena que conjuga también una escritura poética desbordante que no condesciende a una única imagen visual y sí a la acumulación. Parece como si su construcción obedeciese a un deslizamiento metonímico, a la proliferación de las imágenes por contigüidad; un cuadro que bien podría ser cubista ${ }^{76}$. Veamos la parte final de este poema:

Qué comienzos, qué oros, qué trifolias, el conejo, la reina del jade, el frío que interrumpe.

Pero el jade es también un carbunclo entre el río y el espejo, una prisión del agua donde despereza el pájaro hoguera, deshaciendo el fuego en gotas.

Las gotas como peras, inmensas máscaras

a las que el fuego les dictó las escamas de su soberanía.

Las máscaras hechas realezas por las entrañas

que les enseñaron como el caracol

extraer el color de la tierra.

Y la frialdad del jade sobre las mejillas,

\footnotetext{
${ }^{74}$ En los textos que nos ocupan tenemos dos situaciones constantes: una noción de ecfrasis con respecto a la forma como una obra plástica es incorporada al discurso verbal y una expresión visual rica donde abundan elementos pictóricos que exploran el anhelo de Baudelaire, es decir, el estatismo, la simultaneidad, la idea de conjunto que, con una sola mirada, proporciona la contemplación de una obra pictórica.

${ }^{75}$ La selección de este poema resultó una tarea difícil, ya que Lezama en libros como Dador presenta muchos donde el elemento pictórico resulta fundamental. Si no los escogimos es porque aparecen como secuencias, como partes separadas de un mismo cuadro o como varios cuadros. En cambio, este poema presenta solamente una escena pictórica que se bifurca a partir de una sensación; una bifurcación que en términos plásticos presenta elementos e imágenes con color, pero que también articula lo que ya hemos afirmado sobre la escritura lezamiana, esto es, la capacidad dialógica de la palabra, su capacidad de entablar relaciones donde no imperan el sentido o el contenido, sino, como afirma Sarduy, un "espejeo" (SARDUY, 1969, p. 68). Precisamente no es una casualidad que en este poema aparezca un espejo en el momento exacto en que se plantea un vínculo inesperado con el fuego, un elemento opuesto a aquel frío que Lezama busca retratar.

${ }^{76}$ Indicamos que el poema de Lezama podría resultar en un cuadro cubista gracias a las palabras de Francis Frascina al analizar el texto "Metaphoric and metonymic poles" de Roman Jacobson. Según Frascina, el romanticismo, el simbolismo y el surrealismo se asocian a un proceso metafórico, mientras que el cubismo presenta una orientación metonímica, en donde el objeto es transformando en un conjunto de sinécdoques. (FRASCINA, 1998, p. 146)
} 
para proclamar su realeza, el peso verdadero,

su huella congelada entre el río y el espejo.

Probar su realidad por el frío,

la gracia de su ventana por su ausencia,

y la reina verdadera, la prueba del jade,

por la fuga de la escarcha

en un breve trineo que traza letras

sobre el nido de las mejillas.

Cerramos los ojos, la nieve vuela. (LEZAMA, 1994b, p. 378-379)

Es realmente difícil establecer una jerarquización, debido a que los teóricos sobre esta relación interartes coinciden en que no es posible llegar a una definición que incluya todas las posibilidades de la ecfrasis. Aunque quisimos sostener esa diferencia entre lo que sería un uso "no ecfrástico" de recursos pictóricos como el color y la luz en el poema antes mencionado, frente a un fragmento ecfrástico que menciona e intenta recrear por diversos medios ${ }^{77}$ un referente extratextual que no es otra cosa sino una obra pictórica, no podemos decir que realmente esta distinción sea totalmente válida. Simplemente es una discriminación que acentúa dos posibles intenciones distintas del poeta y ensayista cubano con respecto a la relación entre la literatura y las artes visuales ${ }^{78}$.

\subsection{ENTRE LA CARNE Y EL ESPÍRITU: LAS DIMENSIONES DE LA IMAGEN}

José Lezama Lima no teoriza sobre el aspecto visual como tal, pero es innegable la presencia constante de esta visualidad a lo largo de su obra narrativa, ensayística y poética. De esta manera, constatamos la fuerza del fenómeno óptico en la descripción de los tapices, en la imagen del ciervo que huye de la paleta del pintor, en el pájaro escarlata de los cinco colores de la alquimia china, en la fiesta del son de Ma Teodora, en los colores de la cazuela alquímica de José Surí, en "La prueba del jade”, en las imágenes del árbol, la casa y la ciudad

\footnotetext{
77 En el caso de Lezama existen al parecer varias formas de ecfrasis. En algunas situaciones realiza una descripción de cuadros o de imágenes, pero en otras realiza operaciones de superposición entre varias obras de un mismo autor o de varios autores donde una obra, sin ser descrita enteramente, sirve como motivo para una serie de digresiones sobre artistas, obras, estilos, épocas históricas en una muestra de la vertiginosa escritura lezamiana; otros casos evidencian la creación de imágenes mentales difusas, como sucede con Fayad Jamís o con el texto "Pintura preferida" sobre el cuadro "L’Atelier" de Maria Helena Vieira da Silva [figura 24]. Posteriormente nos detendremos más específicamente en este punto.

${ }^{78}$ La separación entre lo que es ecfrástico y lo que no lo es tiene un inconveniente: la teoría de la "ecfrasis nocional" de Heffernan y Pimentel como una variante donde no hay un referente extratextual cuya existencia pueda ser verificada. Esto quiere decir que las cualidades plásticas que atribuimos a los poemas de Lezama Lima harían parte de esa ecfrasis, posibilidad con la que no estamos de acuerdo.
} 
de Portocarrero [figura 16] o en los innumerables lienzos verbales de Paradiso y Oppiano Licario. Contemplemos, por ejemplo, el episodio del fibroma en la matriz de Rialta, la madre de José Cemí y encontraremos los detalles físicos del tumor, las analogías o símiles que colaboran en la configuración de una imago óptica plena. De acuerdo con el narrador de Paradiso:

\begin{abstract}
Dentro de una vasija transparente, como una olla de cristal, se encontraba el fibroma del tamaño de un jamón grande. En las partes de la vasija donde se apoyaba, el tejido se amorataba por la más pronta detención de la sangre. El resto del fibroma mostraba todavía tejidos bermejos, debilitados hasta el rosa o crecidos a un rojo de horno [...]. El fibroma tenía que existir como una monstruosidad que lograba en el organismo nuevos medios de asimilación de aquella sorpresa, buscando un equilibrio más alto y más tenso. El aceite de rábano (como en las destilaciones alquimistas, un líquido oro pálido), iba predominando en aquellos tejidos sobre el color agua de lluvia, más amarillo potencial que el agua de la lámina fluyente. Tanto el aceite de rábano como el agua de lluvia, parecía que le iban dando a esos desprendidos tejidos una coloración amarillenta, como una lámina de oro conservada prodigiosamente en un Libro de Horas [...]. El amarillo de los iluministas abrillantado por el theion hudor, comenzaba a encuadrar los azules, los violetas, los rosados, con los que aquellas fibras en su frasco para una secularidad, disimulaban su monstruosidad con los colores con que se van desprendiendo de la noche las botacillas del alba (LEZAMA, 1996, p. 319-320).
\end{abstract}

Frente a esta evidencia palmaria del poder visual en la totalidad de la obra lezamiana, de la cual tomamos algunos ejemplos, no hay ninguna probabilidad de negar esta "visualidad infinita", a pesar de la no enunciación de esta particularidad en sus ensayos sobre crítica de arte. En cambio, lo que sí encontramos es esa marca característica de su pensamiento: el juego, la dialéctica entre la "carnalidad" o sensualidad de la imagen y su significado "espiritual" o abstracto. Un diálogo entre estas dos dimensiones que no está presente exclusivamente en la lengua lezamiana sino también en las imágenes de la religión católica y en la expresión barroca. No debemos omitir obras artísticas pertenecientes a este periodo que encarnan en sí mismas esa dualidad como la Santa Teresa de Gian Lorenzo Bernini.

Ahora bien, una transposición a la conceptualización sobre la imagen en la escritura crítica del poeta sobre las manifestaciones visuales nos encaminaría hacia el diálogo entre dos percepciones: una, donde la imagen se vincula con la ausencia y el aura -tal como la presenta Lezama y Didi-Huberman-, y que se despliega como tema en los escritos sobre el sistema poético o en su obra narrativa y lírica; otra, con la aparición en su escritura de recursos pictóricos como la luz y el color, y con la ecfrasis como la recreación de una obra artística por medio de la palabra. Sin embargo, aquí radica una singularidad en la postura del autor: una 
preferencia por la disquisición sobre el carácter no iconográfico de la imago que se manifiesta en el siguiente fragmento:

\begin{abstract}
Si dependiese del ojo griego la visión del pintor contemporáneo al llegar a circularizarse la persecución del hecho formal, se refractaría en innumerables ruedecillas. Pero sabemos que al llegar la visión del pintor al muro, no comienza el réquiem de su fracaso, por el contrario, su visión nace ya armonizada con la pululación de la otra ciudad que comienza al saltarse la empalizada del logos optikos. [...]. Ya el mundo del pintor no puede surgir de la visión creada por el ojo, sino de la ciudad que está del otro lado de la empalizada. [...]. Su imagen más allá del límite, de la línea del horizonte, del tabique subterráneo, lo lleva a considerar el mundo de todos los días como maravilloso, eternamente naciente y renovado. Situada la imagen del otro lado, el objeto por el análogo del doble, gana la unidad de los dos órdenes, es forma formante y es imagen dentro de un círculo que vuela (LEZAMA, 1996, p. 235).
\end{abstract}

La renuencia de Lezama a discurrir sobre el rasgo pictórico de la imagen nos hace reflexionar nuevamente acerca de ese carácter metafísico que no obedece al ejercicio del sentido de la visión y que, por el contrario, presupone un salto de la empalizada, un ejercicio de la imaginación por parte del pintor. Una circunstancia que nos recuerda nuevamente el episodio del cervatillo ausente que el pintor debe reconstruir en su memoria y gracias a la facultad imaginativa de ésta. De esta forma, podemos recurrir a las diferentes concepciones sobre la imagen desde ensayos como "Las imágenes posibles" o desde aquellos textos que abordan exclusivamente el sistema poético, y encontraremos ese carácter que involucra ir más allá de la mirada del ojo sobre la physis que le rodea. Una predilección del autor que no debe ir en detrimento de nuestra ya comprobada omnipresencia de la imagen visual en su obra y sî conjugarse con la apreciación de sus textos críticos sobre las expresiones plásticas. Como veremos en páginas posteriores, este factor no directamente icónico y relacionado con el aura resulta primordial en la comprensión del modo como el poeta y ensayista valora las piezas de arte.

\title{
2.8 LOS TIPOS DE ECFRASIS EN "HOMENAJE..."
}

“Homenaje...”, como ensayo dedicado a René Portocarrero, presenta descripciones de pinturas y de obras de otros artistas, que le sirven a Lezama para caracterizar el arte del pintor cubano, pero también para hablar de sus planteamientos sobre la poesía y el sistema poético. Conceptos como inscape, imagen y lejanía ejemplifican este nexo y permiten un diálogo con 
una tradición pictórica diversa, en el que las obras mencionadas se inscriben en una forma de la ecfrasis referencial. Este tipo de ecfrasis presupone la existencia autónoma del objeto y, como descripción, remite al objeto estético como referente, soporte y punto de partida. No obstante, en el caso de su crítica de arte nos encontramos frente a dos peculiaridades: no existe un pacto de citación ${ }^{79}$ y la obra descrita es recreada. Observemos una primera ecfrasis en el ensayo sobre Portocarrero.

En algún paisaje de Mantegna [figura 17], la dicha de las colinas se entreabre al lado de una mágica ciudad enmudecida en la total ausencia de sus moradores. Coliseos, minaretas, campanarios y puertas de entrada en la ciudad, se ofrecen en un procesional de tierra quemada, rodeada de mogotes habitables. Aquí el espíritu de las ruinas se muestra en la lejanía, pero en una lejanía abandonada. En ese abandono de la ciudad ha entrado la muerte, un vultúrido se aquieta en el extremo de un ramaje de un árbol repelado. En el centro del árbol, algunas hojillas se untan de un betún inconmovible de imaginación penetrando en la lejanía antes de extinguirse y esa posesión que el hombre recaba en ese abandono para la ausencia mortal o para las romerías flameantes, elaboran la presencia de un paisaje (LEZAMA, 1994a, p. 226-227).

Esta primera descripción de una obra de arte representa un argumento para la tesis lezamiana acerca de la importancia de la lejanía, de una distancia necesaria donde "la visión tiene que ser llevada al último rincón del mundo" (LEZAMA, 1994a, p.226). Unos párrafos atrás, también se ha referido al paisaje como "el testimonio del recorrido de la imaginación de un pintor" (LEZAMA, 1994a, p. 226), un trayecto marcado por una extensión y no por una cercanía: la pintura paisajística es un ejercicio imaginativo del pintor que recrea un evento distante. Encontramos aquí un lazo con lo que mencionábamos antes sobre la no-visualidad de la imagen pictórica para Lezama Lima, con ese crear lo que no está presente y visible, ese ver "la ciudad que está del otro lado de la empalizada" (LEZAMA, 1996, p. 235). No obstante, esta función de argumento dentro del texto hace que la imagen descrita pierda relevancia como objeto estético, ya que puede ser cualquier paisaje (la ecfrasis comienza con "algún paisaje") de Mantegna, lo cual colabora explícitamente con esa ruptura del pacto de citación explícito. El lector entenderá que la obra de este pintor es solamente un ejemplo de la

\footnotetext{
${ }^{79}$ Luz Aurora Pimentel señala que la ecfrasis es un "pacto de citación explícito", pues "el texto nos invita a buscar el objeto referido para leerlo junto con su descripción" (PIMENTEL, 2001, p. 113). En el ejemplo citado arriba, Lezama contradice este presupuesto.
} 
importancia de una creación pictórica donde opera la imaginación. En este caso, la obra ha sido subsumida por la organización discursiva del ensayo lezamiano ${ }^{80}$.

Otras situaciones de ecfrasis destacadas en este texto aparecen en relación a las obras de El Greco [figura 25] y de Goya. Debe notarse una clara diferencia con la obra de Mantegna antes descrita: estas dos obras tienen nombre y aparecen gracias a una comparación con la obra de Portocarrero en la que Lezama se refiere a la forma en que la ciudad es creada en la "sobrenaturaleza"[figura 16]. De este modo, tanto en las obras de El Greco, Goya y el cubano, la ciudad sería vista desde lo que hemos señalado anteriormente como una idea de artificio, de recreación y reinvención de la naturaleza dada mediante la acción del hombre. De hecho, la noción misma de polis obedece a un orden simbólico y material creado por el ser humano. Así, en las obras descritas tenemos:

En el Monte Sinaí, del Greco [figura 25], la pequeña ciudad parece situarse en el centro de un castillo fortaleza. Llegan las caravanas y los más extraños viajeros, los montes vecinos muestran como cosas humanas en relieve. Los montes rocosos ofrecen escalinatas para llegar a la vaciedad de su culminación. El color gira como una espiral lanzada a lo estelar receptivo. Es la tierra requemada, la ciudad oprimida por la piedra, los montes indiferentes y las escalas para el hombre. Es un lugar propicio a las transfiguraciones. Alcanzar esa altura, esa manera de vivir, es ya transfigurarse. La naturaleza que rodea al hombre en esa dimensión, es ya sobrenaturaleza.

Vemos ahora el prodigioso La Grotte, de Goya, donde lo estelar gravita en tal forma sobre el fragmento de edificación que se muestra, obligándonos a la reconstrucción de una totalidad invencionada, que nos lleva a la inicial de ese momento que va a transformarse. La arquitectura destruida ha sido sustituida por lo estelar, con tal fuerza para el nuevo acoplamiento, que parece una pintura para la complacencia de un demiurgo. Las bromas, las solemnidades, las sorpresas, agrupadas en torno de la mesa, en un lateral del cuadro, mezclan la alegría inocente del escondido debajo del mantel para que lo busquen las palomas, con la figura enfática del hombre báquico, un poco Rembrandt, un poco del Velásquez que se burla de los guerreros, para formar un agrupamiento que transcurre con sorprendida sencillez en sus transportes a una circunstancia no interpretada, pero que, no obstante, parece ofrecerle una tregua (LEZAMA, 1994a, p.255-256). (Los subrayados son nuestros)

Queremos llamar la atención sobre dos procedimientos existentes en estas recreaciones escritas de las obras de los dos afamados artistas. Por una parte, la presencia de juicios sobre

\footnotetext{
${ }^{80}$ Podemos pensar que la obra a la que se refiere Lezama hace parte del Retablo para la Iglesia de San Zenón de Verona. Una de las escenas tiene como trasfondo una ciudad: es la oración de Jesucristo en el huerto. Es extrema la asunción por parte del poeta de esta imagen, ya que la descripción del cuadro está presente solamente en cuatro líneas y el resto está dedicado a sus propios planteamientos, no exentos de ficción, sobre el árbol y la lejanía.
} 
las obras (El color gira como una espiral lanzada a lo estelar receptivo), donde concurren vocablos asociados al sistema poético, como lo estelar y lo telúrico; por otra, la ficcionalización. Este es un rasgo central en la escritura lezamiana de crítica de arte, ya que procesos como la comparación o la transposición tienen como fin no reproducir miméticamente en la escritura la obra plástica sino reinventarla. Una disposición que se acentúa si tenemos en cuenta que no existe un cuadro de Goya con el nombre exacto de "La grotte”. De esta forma, la obra plástica al pasar por el tamiz del escritor ya no es la misma obra, es transformada y llevada a un decir que excede lo perceptible por la vista. Así operan las transposiciones donde una escena marginal en el cuadro de Goya es comparada sucesivamente con un hombre que se esconde tras un mantel y con el hombre báquico de Rembrandt y Velásquez ${ }^{81}$.

No obstante, todavía es posible ver una mayor ficcionalización en pasajes donde intervienen conceptos como las eras imaginarias. De esta manera, encontramos que:

En algún grabado chino Fou Hi [figura 26], fundador del bastón sagrado, empuña la escuadra, su hermana Niu Kua, el compás, ambos se entrelazan por las dos colas unidas. [...]. Entre los chinos, la escuadra sigue siempre el Dosel Celestial, logrando medirlo. Las ciudades de Portocarrero parecen hechas siguiendo esa orientación [figura 16]. La escuadra avanza sobre una curva del compás. La fundamentación casi siempre en colores terrosos, violetas, los arcos, los fragmentos del compás, se resuelven en azules espesos, de profundidad, surcados por el amarillo metálico de la noche estelar. Un amarillo interrogante en un azul cerrado, el azul inconmovible de las crecidas nocturnas, mientras el gnomon rojo, gris, negro, como un procesional va avanzando al seguir la paradojal constelación terrestre del Carro del Templo, es decir, la techumbre, los ejes, las ruedas, la galga, perseguidos por el cuadrado mágico que se descompone en escuadras (LEZAMA, 1994a, p. 257-258).

La alusión a una de las eras imaginarias, "la biblioteca como dragón", le sirve a Lezama para realizar una comparación entre el procedimiento artístico de Portocarrero y un método de medición con connotaciones míticas, esotéricas y hasta masónicas. Fou Hi -héroe civilizador chino que crea y enseña la escritura, la pesca y la caza con trampas- delimita y traza las formas posibles del mundo material, mientras que Niu Koua, su esposa, delinea la forma esencial del mundo celestial y espiritual, el círculo ${ }^{82}$. Sin embargo, la asociación va más allá.

\footnotetext{
${ }^{81}$ Como no encontramos una obra de Goya con el nombre de "La Grotte", podemos pensar que el cubano está proponiendo una obra plástica ficticia que posibilita alusiones a Rembrandt y a Velásquez.

${ }^{82}$ Nos preguntamos si esta alusión al simbolismo de la escuadra y el compás es otra referencia al platonismo o a los elementos estelar y telúrico que aparecen constantemente en los ensayos acerca del sistema poético y, más exactamente, en relación a la imagen. Preferimos esta interpretación a una que contenga elementos de masonería, ya que uno de sus símbolos representa la unión de la escuadra y el compás.
} 
En este fragmento tenemos la hipótesis de que las ciudades de Portocarrero están trazadas de acuerdo a una geometría "celestial”, junto con una caracterización de los colores en términos que los desmaterializan, que les hacen perder sus cualidades físicas en beneficio de ideas como el "amarillo metálico de la noche estelar". Otro elemento importantísimo es la configuración de una escena mítica que podría dividirse en dos partes: los dos hermanos de la mitología china entrelazados por la cola y el esbozo de la constelación. Es curioso que como lectores de esta escena pensemos en una superposición, donde los colores que este autor ve como propios de la pintura de Portocarrero para la ciudad puedan ser los mismos para el "Carro del Templo". Vemos nuevamente una escena pictórica ficcionalizada en la que confluyen una imagen proveniente de las eras imaginarias, una descripción de "todos los colores de Portocarrero", y la figura de una constelación.

Por último, señalaremos los momentos en que las obras de este artista sirven como motivos ecfrásticos. En estas descripciones, su obra no es detallada únicamente de forma general o mediante figuras como los ángeles, las máscaras o las mariposas sino que nuevamente aparece una escritura semejante a la que trata sobre el sistema poético y que, en términos generales, resulta oscura o hermética para el lector. Leemos que "en su dibujo Primavera, el ángel sólo repercute por su ausencia, pero en la lejanía, en el espíritu que agudiza las figuras, ya el ángel era una divinidad escondida" (LEZAMA, 1994a, p. 237), o

En su óleo El ángel dormido, rechaza las virtudes intermedias, o el arquetipo del ángel ascendente, para recuperar una totalidad. [...]. El arquetipo [...] se disuelve en unas pastas envolventes, a las que ha logrado transmitir un absoluto inteligible, una materia interpretada, angélica por su docilidad al eco y a la respuesta del color (LEZAMA, 1994a, p. 237-238) ${ }^{83}$.

Además, no son muchas las obras suyas que aparecen referidas desde el título ${ }^{84}$. Los procedimientos más destacados por el poeta suelen resaltar partes, figuras o temas. Él mismo reconoce este procedimiento, ya que "Un repaso crítico de la plástica de Portocarrero se podría cumplimentar en torno a los agrupamientos por temas, ya ángeles, mariposas, casas del Cerro, crucifixiones, catedrales, plazas, ciudades, juglares" (LEZAMA, 1994a, p. 241). Un método que se relaciona con su propia concepción de la historia, la cual muestra una especie de circularidad o repetición. De ahí su rechazo al estudio y análisis de las obras del artista de

\footnotetext{
${ }^{83}$ No encontramos las obras "Primavera" o "El Angel dormido". Sin embargo, incluimos "Ángeles" [figura 28], pieza a la que Lezama Lima se refiere en otros ensayos como "Máscaras de Portocarrero" ( LEZAMA, 1994, p.221-224).

${ }^{84}$ Aparte de las que ya mencionamos, encontramos también en el ensayo una "Crucifixión en la iglesia de Bauta" [figura 27], el Cristo de Trinidad y Palemón el estilita (las cursivas son del autor). Desafortunadamente no hallamos las dos últimas.
} 
acuerdo a lienzos y piezas determinadas. Un estudio cerrado que no permite el encuentro de motivos que se repiten y están en constante cambio.

En suma, nos encontramos frente a una crítica de arte que procede mediante la observación del fragmento para llegar a una totalidad. Así, el análisis del ensayista parte de figuras aisladas como ángeles, mariposas, flores, crucifixiones, carnavales y máscaras, y aspira a dar cuenta de la obra plástica del plástico, gracias a la observación de estos elementos, de su interacción entre ellos y de su relación con obras de la tradición pictórica universal. Pero no lo hace desde la exclusividad de unas categorías artísticas o desde la trayectoria de Portocarrero: la crítica lezamiana toma como punto de partida esta obra pictórica para continuar los planteamientos sobre la imagen -centro del sistema poético-, la naturaleza y la sobrenaturaleza, y hacia otras digresiones donde encontramos diseminado su pensamiento. Así, un detalle en la pintura se convierte en un pretexto para el examen de la poesía o la presencia de colores vivos conduce a las tonalidades de la alquimia china, una de las grandes culturas que aparecen en Las eras imaginarias. En este sentido, analizamos "Homenaje..." desde una de las premisas que se desarrollan en el ensayo sobre Julián del Casal. En un fragmento de este texto, hallamos que la crítica "tiene que reincorporar un accidente presentándolo en su aislamiento y salvación" (LEZAMA, 1977, p. 66). Desde esta mirada, una de las particularidades que representa para nosotros un punto neurálgico es la exclusión de José Lezama Lima en algunas de las historias del ensayo hispanoamericano gracias a su aparente falta de conceptos y no tanto por su lenguaje. Quizás habría una línea imaginaria, una frontera no cuantificable entre el ensayo y los otros géneros, que permite su omisión y la inclusión de Octavio Paz como representante de esa forma híbrida entre el ensayo y la poesía. Tal vez sea la propia impertinencia de un Lezama que lee la cultura en los términos de sus propias concepciones, de sus propias preferencias y de su particular concepción de la creación estética como una operación de duplicación por la metáfora, y de la historia como una construcción de arquetipos míticos perdurables en el tiempo. "Lector impertinente" - calificación del ensayista que esgrime Alberto Giordano--, la imprudencia de Lezama reside en el grado extremo de "literaturización" del saber que realiza en sus ensayos (GIORDANO, 2005, p. 223-242). Todo es susceptible de ser recreado desde la fícción, o reinventado de nuevo, y frente a la anhelada objetividad de alguien que discurre con conceptos, que describe un objeto artístico en relación a una tradición, a una acumulación de 
saberes, el poeta trabaja con los "ecos", los que oye en la pintura de Portocarrero y en la historia artística y cultural universal.

\subsection{LA ESCISIÓN EN LA VISIÓN: LA COPIA, LA CRÍTICA Y EL ARTE CONTEMPORÁNEO}

En Portocarrero, como todo artista que habita su destino, depende de la noche placentaria que lo rebasa, su icneumon, su fuerza destructiva para lograr una medida lo acompaña con terrible ternura. La aceptación y el rechazo hacen ondular sus flores, el éxtasis de la forma tocada se prolonga en aquella terateia de los griegos, lo maravilloso que tiene tanto de extensión como de costumbre (LEZAMA, 1994a, p. 248).

El pasaje anterior es uno de los mejores ejemplos acerca de la forma de la crítica de arte lezamiana. En él encontramos formalmente dos elementos que nos llaman la atención: la adjetivación y el uso de vocablos provenientes del griego. Enlaces como "noche placentaria" o "terrible ternura" representan una calificación llamativa que no es otra cosa que las figuras literarias de la metáfora y el oxímoron. La primera, presente en una alusión al origen, a la gestación en el vientre materno, y la segunda, en una unión de términos opuestos que generan un nuevo sentido: "terrible ternura". Como podemos ver, este fragmento reúne a nivel formal un fuerte carácter poético con una ficción, a nivel de contenido. En este punto no nos encontramos con un llamado a la recreación de una figura ausente sino con la intención deliberada de constituir el ejercicio crítico como un acto imaginativo. Una premeditación que podemos percibir mediante la presencia de los dos vocablos de origen griego, icneumon y terateia que, incluso explicados por el diccionario de Iván González Cruz, y por el mismo Lezama en otros textos, como la rata del faraón (la mangosta egipcia enemiga de las serpientes) o el adversario del dragón en la literatura medieval y "maravilla o portento" (GONZÁLEZ CRUZ, 2000, p. 167), respectivamente, resultan insuficientes para la comprensión del fragmento antes citado. La única tentativa posible de entendimiento tal vez sea percibiéndolo como un texto autorreferencial cuyo carácter se asemeja más a la elaboración de una máscara o a un disfraz. Un lenguaje poético con metáforas y figuras que dislocan la relación habitual entre significante y significado y constituyen, a su vez, un disfraz de múltiples capas que se superponen.

Más allá de un "disfraz" o de un "artificio", también queremos destacar aquí otro rasgo de la escritura lezamiana que ya habíamos mencionado: la idea de valor. Gracias a que en los 
ensayos sobre crítica de arte existe una continuidad con sus principales nociones acerca del sistema poético, Lezama también teje una red donde pocos artistas caben. No todos los artistas representativos de la vanguardia cubana tienen espacio en su escritura y en su particular concepción de la labor crítica acerca de las manifestaciones plásticas ${ }^{85}$. Igualmente, dentro de su proyecto crítico tampoco hay espacio para artistas plásticos cuya propuesta se encuadre en corrientes más contemporáneas que demanden otros espacios y otras situaciones diferentes a la meramente contemplativa. Un rasgo que lleva a pensar que estos críticospoetas trabajan desde el encuentro visual con la obra, sea un cuadro o una escultura y no desde otros aspectos como la interacción con el público o la salida del espacio consagrado institucionalmente: el museo; situaciones que en alguna medida estaban comenzando a producirse en la isla hacia finales de los años sesenta y comienzos de los setenta.

La idea de valor en Lezama también presupone dos posibilidades: la selección de artistas que presentan algún grado de correspondencia con su sistema poético o que se inscriben en el círculo de la amistad. Un recorte que se relaciona con la imposibilidad del encuentro con piezas realizadas y mostradas en el exterior. Así, temas como las copias de las obras artísticas cobran una importancia inusitada, al no tener acceso directo a las producciones originales. De esta manera, en una de las crónicas ${ }^{86}$ presentes en "Tratados en La Habana", Lezama se refiere a una exposición de arte inglés "presentada en copias de excelente factura" (LEZAMA, 1977, p. 677) y realiza una distinción sobre el arte que puede o no ser reproducido. Así, la gracia o verdadero propósito reside en atrapar el rasgo característico que convierte a la obra en una manifestación única. En sus palabras:

\footnotetext{
85 Jorge Mañach y la revista de avance fueron blancos de la actitud despreciativa de Lezama. Con respecto a esta postura, Reynier Espinosa, en su texto "José Lezama Lima ante la creación pictórica de su tiempo", señala que el poeta cubano muestra desdén hacia la primera generación de artistas vanguardistas, a pesar de sus aportes para la expresión artística de la isla. En palabras de Espinosa, "De este modo, Lezama, al referirse a esa primera generación lo hace con cierto desdeño, ve sus postulados agotados de 'puro hastío de un interregno humoso o en prolongaciones indecisas [...] la técnica infiel y las formas yuxtapuestas, ambas desacordes.' Este juicio lezamiano no se basa en un enfoque objetivo sobre el arte nuevo, sino que juzga esa generación por los aspectos que difieren de su grupo, ante el grito de cambio y avance que proponía buscar, redescubrir. Esta es una de las razones por lo que no escribió mucho acerca de los creadores de la primera promoción y lo poco que escribió va a estar acentuado por esa posición despectiva, como en los casos de sus aproximaciones a los artistas Fidelio Ponce de León, Carlos Enríquez entre otros; sólo escapan de estos juicios Arístides Fernández y Víctor Manuel, tal vez porque ambos, poseían relaciones de amistad con el poeta, quien verá en sus obras una correspondencia con su sistema poético" (ESPINOSA, Reinier. "José Lezama Lima ante la creación pictórica de su tiempo". Disponible en http://www.lajiribilla.cu/2010/n500_12/500_09.html).

${ }^{86}$ El texto que seleccionamos aparece en una sección de "Tratados..." que se llama "Sucesivas o coordenadas habaneras". Son escritos o "estampas habaneras" que Lezama publicó en el Diario de la Marina entre 1949 y 1950.
} 
Ésa es una de las delicias de las copias, precisar en su juego de aproximaciones el fragmento insalvable, el color que al reproducirse en la copia desmaya y se despide. Un verde que se puede reproducir en algunos venecianos y un verde inalcanzable e irreproducible en El Greco (LEZAMA, 1977, p. 678).

No obstante, de acuerdo al poeta no toda obra es susceptible de ser reproducida, lo cual destaca nuevamente una idea de valor, y de aura, inherente a una obra de arte considerada de calidad. De ahí que, por ejemplo, el color verde de El Greco sea irreproducible. Unas líneas más adelante el mismo Lezama concluirá de forma general que el arte no es susceptible de ser copiado. Un planteamiento que nos recuerda la tesis de Benjamin sobre el arte aurático y la pérdida de esa aura gracias a la reproducción. En el texto lezamiano leemos con humor que:

el original aborrece tanto parecerse a alguien, como un alguien desdichado se parezca a él. Su tibiedad y su gloria radican en su bufanda. Su orgullo pregona: nadie, nadie tiene una bufanda dominó. Y el eco jugando sus sílabas le regala un nadie, nadie, nadie (LEZAMA, 1977, p. 679).

Como podemos ver, Lezama desarrolla en su crítica de arte una noción de valor que orbita alrededor de la afinidad de los pintores con sus planteamientos acerca del sistema poético, la amistad y un arte verdaderamente aurático, que no cuestione los cimientos que separan al arte de la esfera cotidiana de acción. Desde este punto de vista asistimos a una operación de selección en varios frentes: escogencia de obras de arte emparentadas con la visualidad y no con las corrientes no figurativas, elección de artistas cubanos pertenecientes a la segunda generación vanguardista y análisis de obras consideradas auráticas, tanto a nivel nacional como internacional. En cuanto a este último asunto, debemos destacar las circunstancias de la Isla y su alejamiento con respecto a lo que sucede en los principales escenarios artísticos mundiales. Este último punto es crucial en la medida en que el acercamiento se produce mediante copias o mediante noticias de lo que sucede afuera, lo cual, de entrada, ya produce una segmentación de la información.

Por último, mostraremos un reparo importante para la crítica de arte realizada por escritores y poetas hispanoamericanos. Es una crítica basada precisamente en el reconocimiento de la importancia de la actividad de difusión, comprensión, descripción y valoración realizada por los escritores. No podemos soslayar el peso de los escritos sobre arte de poetas como Octavio Paz o José Lezama Lima en el ambiente cultural hispanoamericano, pero tampoco debemos pasar por alto sus falencias. Algunas de ellas han sido mencionadas en párrafos anteriores y otras aparecen en textos como Hacia una teoría americana del arte de 
Juan Acha, Adolfo Colombres y Ticio Escobar (1991). De acuerdo a estos autores, en nuestro subcontinente no existe un pensamiento visual desarrollado, gracias a una multiplicidad de circunstancias, entre las que se destacan el énfasis propio del ser humano hacia la palabra escrita -y no enteramente hacia los fenómenos visuales-, y la presencia de un discurso literario sobre las obras plásticas que tiende a destacar el elemento narrativo de la obra de arte. Según ellos:

El crítico y el teórico, mientras tanto, se explayan en consideraciones de lo narrado o representado, sin poner atención en el modo artístico si lo hubiera. Porque la crítica literaria hace esto hasta con las obras artístico-visuales de primera magnitud. Y es que para ello lo narrable constituye uno de los valores estéticos de la pintura (ACHA; COLOMBRES; ESCOBAR, 1991, p. 44).

Esta es una objeción significativa que no solamente atribuye a la aproximación del pensamiento literario al visual un marcado interés en el elemento narrativo sino que critica la inexistencia de una verdadera valoración o juicio sobre el carácter artístico de la obra. Una aseveración que nos conduce al cuestionamiento de la crítica de arte lezamiana, en el sentido que es el mismo juego del lenguaje que pone en escena (o en el papel), el que dificulta un verdadero entendimiento del carácter artístico de las obras plásticas analizadas, sin contar las múltiples digresiones que llevan al lector a un campo que excede al pintor analizado y lo introduce en otros terrenos. A partir de estas circunstancias, es válido cuestionar el alcance teórico y analítico de una crítica de arte que carece de especificidad y preguntarse cómo fue su recepción: ¿realmente realizó una difusión del arte de la isla, pese a su selección? o ¿Alimentó debates o propuestas que llevarían al desarrollo de un pensamiento visual? ${ }^{87}$

\subsection{ALGUNOS PASOS HACIA LAS CATEGORÍAS ESTÉTICAS}

Como hemos visto, la escritura lezamiana acerca de la crítica de arte ofrece dificultades para quien busca en ella la comprensión de la obra de un pintor determinado o el conocimiento de corrientes o escuelas artísticas. No porque este ensayista no realice una descripción y una valoración de las obras presentadas, ni porque no mencione artistas o corrientes. Quizá una hipótesis plausible es que en la concepción de su escritura sobre las manifestaciones plásticas coexisten cuatro formas que cumplen una función de

\footnotetext{
${ }^{87}$ Un pensamiento visual en los términos de Juan Acha, Adolfo Colombres y Ticio Escobar equivale a una reflexión sobre el arte mismo y sus medios, que condujese a nuevas y originales expresiones artísticas.
} 
enmascaramiento: la primera, vinculada con el reclamo de autonomía del ensayo, es el reconocimiento del carácter estético de este género, más allá de la postulación o la expresión de tesis sustentadas por argumentos; la segunda, relacionada con la anterior, donde esas mismas operaciones literarias presentan una ficción o la transformación de la obra plástica al pasar por el tamiz de la literatura; la tercera, el carácter digresivo y acumulativo de la escritura del cubano que no atiende a una esperada "linealidad" o "continuidad" en los planteamientos de la historia del arte, y que superpone planos diferentes como la inclusión de una teoría del poeta Gerard Manley Hopkins (inscape y landscape); y, finalmente, la subordinación de cualquier propuesta acerca de la expresión plástica a su sistema poético, con su consecuente selección o recorte con respecto a los artistas cubanos, sea por la adecuación de sus obras o por los lazos de amistad.

En todo caso, y aun frente a estas características, no es posible ignorar la existencia de unas categorías estéticas en el ensayo "Homenaje a René Portocarrero". Con "categorías", pensamos en los conceptos que sirven de base para sus planteamientos sobre la obra de este creador. Así, algunos de los que revisaremos son el primitivismo, la noción de barroco y la presencia de pintores como Van Gogh y Ucello o Paul Klee y Wassily Kandinsky.

\subsubsection{Aproximaciones al primitivismo, la visión táctil y las opciones de la pintura contemporánea}

Los acercamientos teóricos clásicos al primitivismo suelen incluir los textos Cultura primitiva, los orígenes de la cultura (1871) de Edward Tylor, La rama dorada de James George Frazer (1890) y La mentalidad primitiva (1922) de Lucien Lévy-Bruhl, escritos desde una perspectiva antropológica y cultural que incluye, entre otros, rasgos fundantes como la religión. Sin embargo, y pese a la importancia de estos textos, hemos escogido un enfoque que resalta el elemento estético o de la historia del arte. Desde esta mirada nuestra exposición se centrará principalmente en el modo como aparece este concepto en "Homenaje..." y de acuerdo a las propuestas del crítico e historiador de arte Charles Harrison y del poeta y ensayista Octavio Paz. La elección del mexicano obedece a que también escribe crítica 
poética y a que ciertas zonas de su pensamiento representan un lugar de encuentro con el poeta cubano, además de que ambos se sitúan en un mismo horizonte temporal ${ }^{88}$.

Ahora bien, en una primera aproximación, y de acuerdo a las palabras del crítico e historiador de arte Charles Harrison, encontramos que

De maneira geral, a palavra "primitivo" foi usada desde pelo menos o século XIX para distinguir as sociedades européias contemporâneas e suas culturas de outras sociedades e culturas que eram então consideradas menos civilizadas. Até meados do século XIX, o termo era também usado para descrever obras italianas e flamencas dos séculos XIV y XV. Mas na virada do século seu alcance foi ampliado para referir-se às antigas culturas egípcia, persa, indiana, javanesa, peruana e japonesa, aos produtos de sociedades vistas como "mais próximas da natureza" e ao que muitos historiadores da arte chamaram a "arte tribal" da África e da Oceania (as ilhas do Oceano Pacífico) (HARRISON, 1998, p.5).

El concepto de primitivo se asocia así a culturas y sociedades "menos civilizadas" o más próximas a un estado "más natural" o "tribal", y, en el caso de la pintura, a obras que no presentan perspectiva, aunque este rasgo técnico ya esté en sus comienzos. Entre los pintores primitivos italianos encontramos a Giotto di Bandone (1266-1337) y a Simone Martini (12881344), representantes de la Escuela de Florencia y de la Escuela de Siena, respectivamente, y a Jan van Eyck (1390-1441) como representante de la pintura flamenca. Ahora bien, si continuamos con un desarrollo artístico donde el primitivismo se vincula con la modernidad, encontramos también las ideas de Gauguin al respecto de lo que podría llamarse una "técnica primitiva". De acuerdo al análisis de Harrison:

Gauguin define seu primitivismo, portanto, em termos da "simplicidade", da austeridade e da falta de escala naturalística que caracterizam seu estilo de pintura na Visão. Ele indica que as próprias simplificações formais simbolizam a cultura "primitiva" que representam. Nesse sentido, ele estava seguindo uma tradição primitivista que ligava pessoas "simples" a pensamentos ou modos de expressão "mais puros". Mas também fazia uma associação implícita entre um modo de expressão artística "sem artifícios" e a criatividade -ou potencial criativo- do artista moderno (HARRISON, 1998, p.19)

De acuerdo a la concepción de Paul Gauguin (1848-1903), el carácter más natural atribuido a la pintura primitiva se alía a la inmediatez de la visión, a la simplicidad en los

\footnotetext{
${ }^{88}$ En el primer capítulo habíamos reflexionado sobre el carácter de la crítica de arte de Octavio Paz. Ahora, nos apoyamos en las semejanzas entre ambos poetas y ensayistas para analizar el despliegue del concepto de primitivismo. Entre las razones que nos permiten reunir a estos dos autores encontramos un pensamiento basado en la universalidad del lenguaje poético, en la recuperación de un imaginario mítico y en una ambición enciclopédica acerca de la cultura y la historia. Por otra parte, ambos se hallaban en un mismo contexto generacional y compartían un diálogo en el sentido de que publicaron en Orígenes.
} 
temas (campesinos o personas simples) y a la pureza. Estas tres particularidades: naturaleza, inmediatez y pureza resultan así características de una noción de arte alejada del artificio, entendido como una operación consciente y artesanal que busca retratar la realidad con más fidelidad. De ahí que unas líneas más adelante, Harrison se refiera a los elementos de la pintura de Gauguin y Émile Bernard (1868-1941) en términos de distorsión, simplificación y "abstracción" de la naturaleza, atributos que él relaciona con la herencia simbolista y que pueden resumirse así: áreas aplanadas de colores intensos, distorsiones o simplificaciones como el uso de contornos oscuros por parte de Bernard para circundar y separar áreas de color intenso (recurso que también aprovecha Gauguin).

Ya en nuestro ámbito, podemos pensar el primitivismo como lo hace Ana Cecilia Olmos en su disertación de maestría cuando observa que se trata de una reacción contra el academicismo, el naturalismo y el racionalismo de la estética europea (ARIAS, 1994, 10). Desde este enfoque, la finalidad de autores como Mário de Andrade o José Lezama Lima al trabajar con este concepto distintivo de la modernidad representa una práctica contrahegemónica. En sus palabras, "re-semantizar uma arte primitiva significa, portanto, reabilitála como uma prática contra-hegemônica que opera estrategicamente na configuração de identidades culturais diferenciadas" (ARIAS, 1994, 13). De este modo, cuando el poeta cubano postula el primitivismo como una parte del proceso y del método propios del pintor está reclamando una postura antiacadémica para la pintura y realizando un llamado a procedimientos estéticos innovadores alejados del "naturalismo" y del "racionalismo". Ésa es su posición en "Homenaje" cuando anhela un pensamiento mágico aplicado a la creación pictórica. Según él, “anteriores a toda abstracción y a la geometría de la ornamentación, el pintor siente las imágenes hápticas de los primitivos y los místicos” (LEZAMA, 1994a, p. 229). Nuevamente encontramos ese halo pre-lógico alrededor de la creación pictórica que no se conforma con la observación o la imaginación. Aquí, a semejanza del fragmento sobre la caza del ciervo, existe nuevamente una conjugación de los sentidos o una metáfora en las palabras “imágenes hápticas”, ya que "háptico” designa la ciencia del tacto.

Ahora bien, el hilo argumentativo del texto lezamiano nos permite unir la reflexión sobre el primitivismo presente en "Homenaje..." con la noción del logos optikos griego. El enlace que uniría ambas ideas es la mirada. Aunque es verdad que cuando el poeta y ensayista se refiere al primitivismo, como en las líneas anteriores, lo hace pensando más en la sensación táctil, las imágenes en sí suelen referirse al ejercicio de la visión. La salvedad es que no se 
trata de cualquier percepción visual, ya que se refiere a los primitivos y los místicos, es decir, a una experiencia más relacionada con la unión del alma con un elemento sagrado. Sin embargo, preferimos no apegarnos a una crítica vinculada a estos elementos místicos y religiosos, ya explorados en una de sus vertientes ${ }^{89}$ y destacar únicamente el elemento visual.

El logos optikos lezamiano es el principio que rige el arte griego y que representa un cambio en el método con respecto al pensamiento chino. En palabras del poeta:

¿Quiere lo anterior decir que la tradición del wu wei, del vacío de los taoístas, se opone a la tradición griega del logos optikos? De ninguna manera. Se trata sólo de un cambio de operaciones, de otro sitio donde el pintor libra sus batallas. No era en la fijeza lograda por la imagen dentro de ese círculo de vaciedad, donde se cumplimentaba la detención antes de perderse en la indistinción del bosque. El griego daba su batalla plástica en el peligro del contorno. El límite y la infinitud luchaban hasta que la zona oscura retiraba sus naves. El contorno, en el visible simbolismo de las figuras y en el cuerpo humano, quedaba siempre por encima del devenir, del lado del devenir como logos.

Cézanne se estremecía al observar que el contorno le huía. Allí están ya señalados los dos peligros que han sido poderosamente creadores en la pintura contemporánea. Uno es un peligro ancestral: lograr un vacío creador, engendrar y fijar dentro de esa suspensión. El otro es las ondulaciones o las serpientes del contorno (LEZAMA, 1994a, p. 231).

A partir de la visión se configura en la crítica de arte lezamiana toda una reflexión alrededor de las características del arte chino, el griego y el moderno. Pese a que no explicaremos las peculiaridades del arte oriental y su carácter dialéctico, observaremos la manera divergente como se configuran las otras dos formas estéticas. De este modo, la mirada atenta y con un valor espiritual, la idealización, se convierte en el principio generador del arte griego. Pese a que no podemos hablar de ellos en términos de primitivos debido a que la filosofía desde Sócrates estaba centrada en el hombre y percibía a la naturaleza como un otro que lentamente va alejándose del mito para convertirse en objeto de estudio (Aristóteles disecaba animales, por ejemplo), es esta primera concepción del arte occidental la que es contrapuesta por José Lezama Lima al arte moderno representado en su más grande artífice:

\footnotetext{
${ }^{89}$ Preferimos alejarnos de la corriente mística y esotérica, presente en textos críticos sobre Lezama como el de Margarita Junco Fazzolari, y aproximarnos a otros enfoques, inclusive no literarios. Por ejemplo, el cineasta español Val del Omar (1904-1982) presenta en 1955 ante la UNESCO su "Teoría de la visión táctil" (publicada en 1959 en la revista Espectáculo de Madrid). En ella consigna que "Hay que convertir a las distintas luces que inciden en una escena en distintos pinceles palpitantes, en dedos sensibles a las superficies que palpan, hay que saber expresar esa sensibilidad reactiva"(http://www.valdelomar.com/pdf/text_es/text_5.pdf. Consultada en 5 jun. 2013). Esta teoría hace de la iluminación el elemento que enlaza nuestras percepciones visuales a las táctiles por medio de las ideas de temperatura y sustancia o relieve. Es una proposición interesante de la que no sabemos si Lezama tuvo noticia por medio de los autores españoles que visitaron Cuba como María Zambrano.
} 
Paul Cézanne. Así, la noción de lo acabado, del límite que, según Lionello Venturi, hace parte de la idea de belleza platónica y aristotélica junto con el orden y la simetría, (VENTURI, 2007, 51) se convierte en una de las dos opciones a las que se enfrenta el artista “contemporáneo". La otra posibilidad es la creación a partir del vacío, de lo abierto, de lo que no tiene límite, que es la situación de un artista moderno como Cézanne. Mientras que los griegos trabajaban en los estrechos límites de una imitación de la naturaleza ya dada (el cuerpo humano) idealizándola (estamos pensando en los grandes escultores como Fidias y Praxíteles), los modernos no pueden apelar a la mímesis porque no existirían unos moldes previos, una naturaleza a imitar. De esta forma, Cézanne, considerado el gran moderno, desafiaba así los principios que la Academia todavía dictaba y que seguían artistas como Bouguereau, preocupados más en un arte naturalista que todavía cumplía un pacto de verosimilitud con la "realidad".

De una forma u otra, encontramos el carácter "abierto", plural y antiacadémico de la modernidad, en contraposición a las formas cerradas y delimitadas del mundo artístico griego. Debemos notar que esta particularidad de lo "abierto" también presupone los diversos tipos y grados de "resemantización" que señalaba Ana Cecilia Olmos con respecto al primitivismo. De este modo, asistimos a una primera versión del significado de primitivismo reclamado por Lezama para el procedimiento en la pintura, posteriormente una propuesta de visión táctil también vinculada a este concepto en "Homenaje..."- y luego la constitución de dos maneras diferentes de concebir el arte a partir de la visión del contorno y de lo abierto. A pesar de que esta última no se relacione directamente con las peculiaridades de una expresión primitiva, es un elemento que orbita alrededor de la teorización lezamiana sobre las posibilidades o "peligros" a los que se enfrenta el pintor moderno.

Por último, observaremos una versión poética de la noción de primitivismo. En "Homenaje..." hallamos que:

Entre el envío de la penetración y la imagen y la melodía de la forma interna proliferante, el artista cuida una semilla, es un homo humus. Es decir, devuelve una forma viviente y una posibilidad germinativa. En cualquiera de los trabajos de Portocarrero, aparece siempre la lentitud, el ceremonial, el sacramento de la semilla en el homo humus. Su ceremonial calmoso le permite prolongar la vía contemplativa en la terraza donde la luna alcanza el signo de las fiestas de la recolección, donde el sol alancea lo germinativo. Un artista tan ricamente dotado como Portocarrero, en esa dimensión del guardador de la semilla, tiene que conllevar un tiempo de espera paralelo a ese germen configurado en hecho concurrente, imagen, penetración, melodía y forma interna en devenir (LEZAMA, 1994a, p. 228-229). 
Un tropo, "la semilla", que también se desarrolla en un ensayo de Octavio Paz que precisamente lleva este mismo nombre, y que se refiere al tiempo representado en la obra del primitivo mediante la imagen del germen y la máscara. Así:

La obra del primitivo revela el tiempo de antes. ¿Cuál es ese tiempo? Es casi imposible describirlo con palabras y conceptos. Yo diría: es la metáfora original. La semilla primera en la que todo lo que será más tarde la planta raíces, tallos, hojas, frutos y la final pudrición- vive ya con una vida no por futura menos presente [...]. El presente se revela y se oculta en la obra del primitivo como en la semilla o en la máscara: es lo que es y lo que no es, la presencia que está y que no está ante nosotros (PAZ, 1984a, p. 26).

En el texto de Lezama encontramos esa idea del ser que todavía no es, observamos la idea de la simiente y también la imagen de su guardador, la cual no se restringe únicamente a Portocarrero sino también a algunos vocablos que se convierten en metonimias del pintor como homo humus. Esta imagen del artista como la tierra donde la semilla crece y pasa de ser una "potencia" a un "acto", también aparece en el apartado donde "la luna alcanza el signo de las fiestas de la recolección, donde el sol alancea lo germinativo", una clara referencia a las celebraciones o ritos de fertilidad. Ahora bien, en el fragmento de Paz, la semilla que también es la máscara, es un elemento que esconde un futuro y un ser desconocido. Este misterio junto con la idea de un tiempo que no es ni histórico (lineal) ni religioso (cíclico) es lo que nos abisma frente a la contemplación del arte primitivo.

Las similitudes entre la manera como ambos poetas desarrollan esta imagen de la semilla es muy fuerte, pero no así en lo que concierne a la elaboración teórica. La propuesta de Lezama presenta una idea general del pintor como aquel que posibilita el tránsito hacia la imagen, mientras que Paz se ciñe estrictamente a la idea de primitivismo. La continuidad con el sistema poético es clara y ensayos del cubano como "Preludio a las eras imaginarias" nos recuerdan claramente esa conexión. Para nuestro escritor el poeta, al igual que el pintor, representa la figura del posibiliter, el guardián del potens, de la poesía como posibilidad infinita. Una idea de poiesis como creación que se extiende también al pintor, en la medida en que ambos han de crear un cuerpo -el poema, una pintura- que en el devenir metafórico cristalice en imagen. De este modo, la presencia de los elementos del sistema poético es deliberada y estructura la crítica de arte lezamiana. 


\subsubsection{Los otros principios: Van Gogh y Ucello; Klee y Kandinsky}

A arte não reproduz o visível, mas torna visível

Paul Klee. Confissão criadora

Cuatro artistas de corrientes pictóricas diferentes son mencionados en "Homenaje...". No solamente presentan posiciones disímiles con respecto al tema estético sino que también se encuadran en momentos históricos que llegan a una distancia notable. El primero, Paolo Ucello (1397-1495), es un pintor del Renacimiento italiano que se destaca por el uso de la perspectiva para crear efectos de profundidad, y no tanto para realizar secuencias narrativas dentro de la pintura. Entre sus cuadros más famosos se encuentran "La batalla de San Romano" (1438-1440) y "San Jorge y el dragón” (1470). El segundo, Van Gogh (1853-1890), reconocido pintor del post-impresionismo. El tercero, Wassily Kandinsky (1866-1944), artista abanderado del arte abstracto. Y, finalmente, Paul Klee (1879-1940), músico y artista plástico suizo-alemán, cuyo arte no es de fácil definición, ya que suele ser asociado al expresionismo, a la Bauhaus y al surrealismo.

Es curiosa la manera como Lezama Lima entabla el diálogo entre estos pintores. Nuevamente, y de acuerdo con lo que señalábamos acerca de su concepción sobre la crítica, el poeta no privilegia una relación causal sino un vínculo donde impera el "eco" o la "frase entreoída". Así, aplica una idea de Paul Klee como el "hecho formal" a pintores como Uccello y Van Gogh, y relaciona el "principio de contacto eficaz" de Kandinsky con la propuesta del pintor suizo-alemán. De esta manera, observaremos primero la forma como el ensayista presenta el planteamiento de Klee y luego veremos esta teoría desde su propio autor.

Así podía hablar Klee de la sinfonía formal, del arte como génesis no como producto. En breves líneas nos ha señalado lo que para él era el camino de la expresión artística. El fuego en su devenir, en la energía humana de su propagación, traspasado a la mano que lo lleva al cuadro donde brota una chispa que lo lleva otra vez al ojo. Existe para Klee una fuerza formante, que liberada de todos los demás elementos, logra constituirse. Pero para que el pintor obedezca a la totalidad de su fuerza formante, había ya que romper con el logos optikos de los griegos. [...]. La sinfonía formal de Klee se logra en la interacción de lo vertical de la esfera lejana con la horizontal de "en alguna parte". Ya el mundo del pintor no puede surgir de la visión creada por el ojo, sino de la ciudad que está del otro lado de la empalizada. Allí encuentra amigos, familiares muertos, cabañas a la orilla del mar, habitadas por pescadores silenciosos de inmensas redes. Su imagen más allá del límite, de la línea del horizonte, del tabique subterráneo, lo lleva a considerar el mundo de todos los días como maravilloso, eternamente naciente y 
renovado. Situada la imagen del otro lado, el objeto por el análogo del doble, gana la unidad de los dos órdenes, es forma formante y es imagen dentro de un círculo que vuela (LEZAMA, 1994a, p. 250-251).

Esta cita extensa nos permite percibir en su propuesta una conciencia sobre el carácter musical de la búsqueda artística de Klee y a la vez una manifestación unívoca sobre lo que considera debe ser el proceso creativo de la plástica. Desde este punto de vista, dividiremos el análisis del apartado anterior en tres partes: una primera dedicada al elemento musical en la teoría de Klee; una segunda volcada en el procedimiento estético y una última destinada a la manera y al lenguaje como Lezama despliega sus planteamientos a partir de la teoría del artista suizo-alemán.

Desde las primeras líneas del ensayo percibimos la conjunción de lo pictórico con lo musical en el arte de Klee. Tal comunión se explica por el hecho biográfico de que el pintor fue violinista y de su constante preocupación por los lazos entre ambas artes, que él considera temporales ${ }^{90}$. Un vínculo que podemos percibir al comienzo del ensayo del pintor titulado “Confissão criadora” (escrito en 1918 y publicado en 1920) cuando, junto con la aseveración del arte pictórico como expresión temporal, encontramos una reflexión sobre los elementos plásticos que incluye términos exclusivamente musicales como "unisonancia" o "polifonía" (KLEE, 2001, p. 44). En el prólogo de Günther Regel a Sobre arte moderna e outros ensaios (libro que contiene el texto "Confissão criadora"), él relaciona este lazo entre la música y la pintura a la preocupación con la "forma". Desde su punto de vista:

Klee procurava, por assim dizer, um equivalente visual para aquilo que a música era capaz de tornar audível. Isso se evidencia na conexão inegável entre $A$ arte da fuga de Bach e o modo como Klee pensava a composição de seus quadros. Como na forma artística da música polifônica contrapontística, em seu trabalho ele estava empenhado em desenvolver um tema da forma e elaborá-lo, diversificado em vários aspectos, segundo princípios relativamente vigorosos, relacionados à organização formal, mas assumidos em cada caso de maneira própria (REGEL, 2001, p. 19).

Resulta comprensible que un poeta como Lezama Lima, cuya poesía, como vimos anteriormente, busca crear una visualidad plástica dentro de un marco musical y fonético propio del poema, muestre afinidad con un pintor como Paul Klee, quien también intentaba

\footnotetext{
${ }^{90}$ En el Laocoonte de Lessing se señala que la principal diferencia entre la pintura y la música es que la primera representa un arte espacial y la segunda un arte temporal. El pensamiento de Klee al respecto no deja lugar a dudas, ya que para él este planteamiento "não passa de uma divagação erudita" (KLEE, 2001, p. 46) porque en el movimiento, y, por ende, en el tiempo, un punto se convierte en línea. Además, el espectador necesita tiempo para comprender un cuadro en su conjunto.
} 
reflexionar sobre la conjunción de las artes. Sin embargo, a nivel teórico la proximidad aumenta cuando el cubano asume la noción de "hecho formal" como un principio fundador de lo que él asume que debe ser el ejercicio pictórico. Unas líneas más adelante en la cita ya reproducida ("El fuego en su devenir, en la energía humana de su propagación, traspasado a la mano que lo lleva al cuadro donde brota una chispa que lo lleva otra vez al ojo") encontramos una paráfrasis de un párrafo de "Confissão criadora", pero con una omisión: la comparación del movimiento del fuego con la génesis de las Escrituras. Una exclusión reveladora que puede interpretarse como una voluntad del poeta por alejarse de cualquier alusión al elemento religioso, a Dios. A diferencia de sus escritos sobre el sistema poético, en este texto sobre Portocarrero el autor explora una vertiente exenta de cualquier referencia a la divinidad como fin último o como inspiración.

El centro de la relación de Klee con los otros pintores, el hecho formal, aparece dilucidado hacia la mitad de la cita extensa que transcribimos. Aquel "Existe para Klee una fuerza formante, que liberada de todos los demás elementos, logra constituirse", pero liberada del logos optikos griego, constituye el comienzo de la definición en palabras lezamianas del "hecho formal". De acuerdo al poeta, y en fragmento que no incluimos, esa "fuerza formante" representa "el sentirse invadido por las fuerzas que ascienden, por la energía cosmológica, por las invisibles pero respirantes interrelaciones entre el devenir y el acto que expira" (LEZAMA, 1994a, p. 250), un pasaje que a simple vista parecería aludir a las fuerzas desconocidas, intangibles e invisibles que gobiernan el acto creativo; en otras palabras a la inspiración. Una impresión que queda desmentida unas líneas después cuando su autor, apartándose del concepto del artista europeo, retoma su reflexión acerca de la imagen.

Ahora bien, la propuesta de Klee acerca del "hecho formal" podemos verla a través del crítico Günter Riegel, autor del prefacio a la edición brasileña de sus textos. Según él, la forma debe entenderse:

no sentido do caráter da forma, isto é, o sinal característico essencial da forma que determina o todo, que abrange em sua combinação de efeitos a característica de uma forma e o seu significado geral. Esse caráter é preservado no processo de configuração como um tema -que não chega a ser o enunciado, mas o objeto sobre o qual e com ajuda do qual algo deve ser enunciado (RIEGEL, 2001, p. 19).

El "hecho formal" tal vez podemos entenderlo como la combinación en el cuadro de todos los elementos que forman la composición (término musical que le gustaba a Klee) y 
cuyo referente no necesariamente remite al mundo exterior sino que es un objeto que enuncia un "algo", un elemento que va más allá del "objeto" plasmado en la obra. En palabras de Klee, en otras secciones de su texto "Sobre a arte moderna", la obra al plasmar solamente una parte de la forma, de ese todo, lo hace de manera que no es enteramente naturalista (una mímesis) sino que incluye una deformación. En sus palabras:

Gostaria agora de considerar a dimensão dos objetos em um novo sentido, procurando mostrar como o artista costuma chegar a uma "tal" deformação, aparentemente voluntária, das formas naturais.

Em primeiro lugar, ele não atribui a essas formas naturais de manifestação o significado coercitivo que elas têm para os muitos críticos realistas. Ele não estabelece um vínculo tão forte com uma tal realidade, porque não vê nas formas finais a essência do processo da criação natural. Pois, para ele, importam mais as forças formadoras do que as formas finais (KLEE, 2001, p. 64).

La noción de "fuerza formante" o "hecho formal" puede leerse así como la transformación o deformación realizada por el pintor con respecto a las formas ya existentes del mundo exterior. Así también lo lee Lezama al final de la extensa cita cuando se refiere a que "Ya el mundo del pintor no puede surgir de la visión creada por el ojo, sino de la ciudad que está del otro lado de la empalizada". El afán de copia sustentado en la visión aguda sobre los objetos es superado por una dación de forma en la que interviene la imago, el doble metafórico, como diría el poeta y ensayista. Los elementos del mundo físico deben ser reemplazados por la visión interna del pintor y por cada uno de los elementos pictóricos para formar una composición. Así lo reconoce Klee con el concepto de "forma" y con la idea de “deformación”, y Lezama reúne esta digresión aparente con la argumentación sobre el mismo Portocarrero.

En torno a Kandinsky, José Lezama Lima afirma que el "principio de contacto eficaz" y el de "necesidad interior" del pintor ruso se relacionan con el "hecho formal" de Klee. En De lo espiritual en el arte, el artista ruso afirma: "A harmonia das cores baseia-se exclusivamente no princípio do contacto eficaz. A alma humana, tocada no seu ponto mais sensível, responde. A este fundamento, chamaremos o Princípio da Necessidade Interior" (KANDINSKY, 1912, p. 60). Ambas teorías, la de Kandinsky y la de Klee, representan un estudio sobre la trasmisión de forma en la obra de arte, sobre el modo como debe realizarse un cuadro de acuerdo a sus componentes (líneas, punto, plano, color, figuras geométricas). Mientras que Kandinsky atribuye a cada color un efecto en el alma humana, Klee reflexiona sobre ese 
elemento interior, sobre ese elemento que informa el contenido del objeto plástico y que no tiene una clara referencia en el mundo físico. De ahí que no haya "oposición", siguiendo a Lezama, entre el "en alguna parte" (de Klee) con el "este" de Kandinsky. Ambos pintores están relacionados por su búsqueda y su estudio sobre la composición artística, sobre los componentes de la expresión estética, de una manera que nunca se desliga de la música (Kandinsky toca el piano y el violonchelo y se interesa por Wagner y Schönberg).

Por último, nos llama la atención la presencia de pintores como Van Gogh y Ucello girando alrededor de los conceptos de "hecho formal" y "principio de contacto eficaz". La razón para el lazo es el análisis acerca de Portocarrero. El mismo Lezama nos dice:

Pero hay una precisión, una nitidez, donde el pintor se libera de la condenación de los sucesivo, para lograr el "hecho formal" fuera de lo temporal, un "éste" cuya polarización es el espíritu universal. [...]. El sumergimiento del "éste" trae como consecuencia el surgimiento del hecho liberado de las secuencias. Hay un hecho puro que el artista siente ascender. Van Gogh pinta unos zapatos viejos, parecen usados por todos los hombres y por un solo hombre. Uccello dibuja una copa de cristales talismánicos, queda como el arquetipo del cuenco de la mano que refracta la cascada (LEZAMA, 1994a, p. 252).

Lezama al destacar el "hecho formal", como una situación que rompe con la sucesión temporal, reivindica una poética de la libertad para el arte plástico. Una poética que se sustenta en la investigación por parte del propio artista de sus medios de expresión y en la manifestación de un arte plástico que, al igual que la poesía, constituye una imagen, o un doble metafórico de esa Imagen ideal platónica que él propone como centro de su sistema poético. No es gratuita esa última representación pictórica: Uccello no dibuja una copa de cristales y sí el espejo cóncavo de una cascada.

\subsection{DESDE LA OTRA ORILLA}

La complejidad y la gran variedad de motivos en el ensayo "Homenaje a René Portocarrero" favorece un estudio amplio sobre un gran abanico de temáticas pictóricas, históricas y culturales, del cual nosotros hemos realizado un recorte que privilegia, en mayor medida, el carácter ambiguo y oscilante del ensayo de crítica poética, su inserción en una tradición cuya raíz se remonta al siglo XIX y a la idea de un lenguaje sugerente en "La filosofía de la composición" de Edgar Allan Poe, las nociones de imagen y aura, el ejercicio de poeta-pintor en Baudelaire y el examen de las poéticas visuales y de algunas categorías 
estéticas presentes en este escrito como el primitivismo, el "hecho formal" de Paul Klee y el "principio de contacto eficaz" de Wassily Kandinsky.

El carácter oscilante de la propia escritura lezamiana nos permitió la salida del marco principal del texto hacia el análisis de algunos temas, sin los cuales no es posible la comprensión de los propósitos de un ensayo cuya máxima ambigüedad -y también mayor riqueza- se instala entre los trazos de una especificidad propia de la teoría y la crítica artística y la autonomía del género ensayístico, donde emergen una "literaturización del saber" y "[una] autoconstrucción de la figura del autor en su relación con el mundo", como aseveran los críticos Alberto Giordano y Liliana Weinberg. En este sentido, pareciese que nosotros ejecutamos también una operación similar a la de la misma escritura lezamiana al salir de las fronteras del texto y trasegar por la senda de la historia de una escritura poética sobre los fenómenos estéticos, las posibilidades entre "Texto" y "Obra" o las categorías de "placer" y "fruición", los límites de la crítica de arte en relación a la historia, o al regresar a la poesía y a una escena de Paradiso con apartados de una visualidad innegable. Así, a lo largo de este capítulo nuestro movimiento fue pendular: una fluctuación entre el "homenaje" al artista y la reflexión sobre los conceptos centrales del universo lezamiano desde una perspectiva que intentó evitar el lugar común.

No realizaremos aquí una síntesis del trabajo desplegado en las páginas anteriores, pero sí queremos retornar a una problemática que nos parece central: la existencia de dos orientaciones en su expresión crítica sobre los objetos plásticos. Esta alternativa podemos leerla a través de los escritos acerca de Fayad Jamís y Luis Martínez Pedro [figura 13] y de la propuesta que hemos venido desarrollando alrededor de la manera como Lezama evita la referencia a artistas que trabajen en un arte no representativo. En otras palabras, en la elaboración de textos críticos sobre un arte que aún posee referentes externos y la presencia de otro tipo de evaluaciones y comentarios basados en artistas que se aproximan a manifestaciones no figurativas.

En contraste con las valoraciones sobre un arte de veta más "realista", el procedimiento crítico acerca de las expresiones que se aproximan al arte abstracto se caracteriza por el acento en la descripción y en la ecfrasis, y no tanto en el discurrir narrativo. Así, Tintas [figura 11], la presentación que escribe Lezama en 1971 para la muestra de Jamís en México, es una descripción que aspira a captar detalles de la totalidad de la obra, percepción de los 
“ecos", de "las máquinas", de "los fragmentos de árboles", que como práctica crítica nos recuerda la predilección de Lezama por el detalle. Así:

Parece en estos dibujos y aguadas de Fayad Jamís, como si se tratase a veces de interpretar un trabajo anterior, como si hubieran llegado a su lejanía familias secretas, flagelos amiboideos o simples crujimientos de la materia ansiosa de respirar [...]. Un trabajo gobernado y dirigido sobre otro trabajo invisible que raspa, añora, rectifica. Máquinas irreales, diseñadas por la imagen, lúdicas, como dólmenes sin finalidad, en espera tal vez de que un cataclismo les dé su función propia o su costumbre adivinatoria [...]. El ojo sigue dominando, trazando las secretas escalas de un imperio que se deshace y reconstruye por instantes, mientras cada color en su recuerdo de variante parece desplazarse movido por la brisa [...]. Fragmentos de árboles posibles que buscan otra unidad, impulsados por otro mundo que los tienta, como si gozaran de una poderosa emigración de las formas. [...]. La forma jugando las dos esferas comunicantes: círculos sobre dólmenes, tortugas emigrantes en un trozo de hielo, sosteniendo con sus cuatro patas, como en las fábulas chinas, lo estelar. [...]. De pronto, las embarcaciones se detienen en el ojo de la imagen, entonces podemos entrever la nueva ciudad. [...]. En esos toneles que estallan en el sueño, Fayad ha extraído sus rojos entrelazados con sus negros, sus sienas quemados, sus azules alusivos a lo inmediato, sus amarillos que interrogan o enfurecen en la luz. Y todos los colores que maneja con mágica alternancia, removidos, avanzando, penetrando vorazmente en la nueva ciudad. [...]. Su materia acariciada y recorrida sin cansancio, es ya la espera que proclama y decide con las comprobaciones del minero y el despertar del niño con su esfera de incesante rotación (LEZAMA, 1971, p. 7-10).

La diferencia que hemos leído, en realidad, es simplemente una alteración en el énfasis. Como un microcosmos de los textos más representativos y extensos de nuestro autor sobre artistas como Mariano Rodríguez [figura 12], René Portocarrero a Amelia Peláez, el escrito sobre Jamís (uno de los últimos de Lezama de acuerdo a la cronología de Capote) es una continuación de los mismos planteos sobre la imagen, las eras imaginarias, el elemento háptico, la importancia del color y la lejanía-imago ciudad, con un única diferencia: el realce de la descripción, la valoración del fragmento. De modo que solamente hay una desemejanza formal entre aquellos nombres centrales en la valoración plástica del poeta y aquellos que demuestran una veta más "abstracta”.

En suma, hemos visto en esta acercamiento crítico al ensayo "Homenaje a René Portocarrero" un análisis cuyo centro de irradiación son las ambigüedades presentes en la escritura de la crítica de arte de Lezama; imprecisiones que nos permiten un movimiento de vaivén entre una imagen visual y otra de cuño metafísico, entre la autonomía estética del ensayo y la cientificidad de la crítica, entre la poesía con su capacidad evocadora y una escritura denotativa, entre la ecfrasis como recreación e reinvención en palabras de un objeto 
plástico y una escritura visual al modo de Baudelaire. Un eje que nos permitió un movimiento en varias direcciones a partir de un único texto crítico, pero que también nos mostró la cohesión de la totalidad de la obra lezamiana. Con el poeta, ensayista y novelista cubano no hablamos tanto de fases, etapas o cambios en su pensamiento, y sí de una gran unidad donde los ensayos se integran con las reflexiones y el lenguaje de su poesía y de sus novelas. 


\section{CONCLUSIONES}

Los dos ensayos trabajados, "Paralelos. La poesía y la pintura en Cuba en los siglos XVIII y XIX", más centrado en el discurso histórico de las dos artes en la isla, y "Homenaje a René Portocarrero", orientado al ejercicio de la crítica, fueron los dos escritos que nos posibilitaron un encuentro con la idea de una visualidad inherente a toda la obra lezamiana. Pese a que este escritor rechaza la asunción del carácter puramente óptico de la imagen y prefiere una concepción abstracta y también platónica, vimos que en estos dos textos abunda uno de los recursos pictóricos más importantes: el color. Con José Lezama Lima hallamos un lenguaje rico en tonalidades, en descripciones, en metáforas y en imágenes que provienen de una "sobreabundancia" de la palabra -como diría el autor- y nunca de su brevedad o concisión. En vez de una escritura lacónica, descubrimos una desbordante que oscila entre comparaciones y metáforas inusuales y cuyo resultado es una imago original, única y contundentemente visual, óptica. De ahí que encontremos textos verdaderamente iconográficos que no se restringen a una mera descripción de objetos o de cuadros de Portocarrero o de otros artistas, sino que también están presentes en sus novelas y poemas. Así, más allá de un relato descriptivo que recurre a las gamas tonales para resaltar las cualidades físicas y visuales de los objetos, sean lienzos o cuerpos -como el tejido-fribroma de Rialta en Paradiso-, nos enfrentamos con cuadros verbales cuyo eje es la creación por la imagen, una imago óptica sugerente y evocadora.

La comprobación de esta "visualidad infinita" en la obra lezamiana nos condujo a la reflexión acerca de la relación entre la pintura y la poesía y la figura del poeta-pintor. Con estos dos temas como pilares de nuestro análisis anduvimos algunos caminos de los estudios interartes, como las recientes reflexiones sobre la ecfrasis y el desarrollo histórico de la frase horaciana Ut pictura poesis, y también recorrimos los senderos de una poética visual de acuerdo a este escritor, una poética en la que analizamos los criterios que conforman su historia y crítica de arte.

En el caso de la estampa del poeta-pintor, pensamos en Charles Baudelaire y en la lectura particular de Lezama Lima sobre este autor. Gracias a él y a su pensamiento sobre la expresión visual, pudimos entender el alcance y las características de la poética del cubano en torno al fenómeno plástico. La relación de aquél con Delacroix, su tentativa de crear cuadros verbales en su poesía, su reflexión sobre el artista moderno se convierten en los ejes sobre los 
que se funda toda la concepción lezamiana acerca de las manifestaciones pictóricas. Cuando pensamos, por ejemplo, en el colorido de los poemas baudelerianos, en su ambición de subordinar la secuencia propia del lenguaje discursivo a una escena pictórica, o en el dinamismo involucrado en el sistema de las correspondencias con sus analogías entre los diferentes planos sensoriales, estamos leyendo también las pretensiones de José Lezama Lima. Para él los rasgos más importantes de lo visible también son el color y el movimiento, particularidades, éstas, que reúne su escritura poética, narrativa y ensayística y que son ponderadas en los pintores y en obras como "El libro de horas del Duque de Berry" de los hermanos Limbourg o el "Caballero Da Fogliano" de Simone Martini, entre muchas otras, y que aparecen también en otros ensayos como La expresión americana.

En cuanto a una poiesis presente en la crítica de arte del cubano, descubrimos un imperativo creativo que quizás también proviene de la lectura del autor de Las flores del mal hecha por el cubano. Cuando Baudelaire en Le peintre de la vie moderne afirma, con respecto al arte de Constantin Guys, que "es difícil para la simple pluma traducir un poema semejante, hecho de mil croquis, tan vasto y tan complicado" parece que estamos frente a la noción de una interpretación creativa. En este sentido, el término "traducir" se convierte en un vocablo que le permite a este poeta-crítico sobrepasar la dualidad entre la imitación y la imaginación a favor de esta última, y se transforma en el correlato de la interpretación creativa. Si pensamos, por ejemplo, en un ensayo como "Homenaje...", la traducción o ecfrasis lezamiana de las obras plásticas no es una descripción que nos permita encontrar la obra fácilmente. Por el contrario, algunas de las pinturas descritas no corresponden con el nombre indicado o únicamente aparecen señalados fragmentos que se colocan en diálogo con cuadros de otros artistas, sin contar los casos en los que la obra pictórica es una excusa para discurrir sobre el sistema poético o acerca del concepto de las eras imaginarias. De esta forma, Lezama re-crea la pieza estética dentro del lenguaje, opera sobre ella una metamorfosis que presupone un lector dispuesto a interpretar de modo creativo, y ambos, escritor y lector, se convierten en autores de una nueva obra pictórica dentro del discurso.

Ahora bien, si existe un imperativo creativo a la hora de re-inventar las obras plásticas en el ensayo, podemos pensar que hay también unas categorías críticas propias. Desde esta perspectiva, la lectura y los juicios de José Lezama Lima sobre los pintores incluyen analogías entre obras que, a simple vista, no guardan ninguna relación. Así, la forma como René Portocarrero pinta la ciudad de La Habana es susceptible de ser comparada con cuadros de 
Mantegna y Bellini, entre otros, mediante una poética del fragmento. En ésta un segmento de una pintura o una impresión o recuerdo de ella es suficiente y susceptible de comparación con otra obra o una porción de la misma. El modelo más claro es la equiparación del cuadro "Los negritos" (o "Los pilluelos", su verdadero nombre) de Juana Borrero con "La Gioconda" de Da Vinci. En este cotejo impera la reminiscencia o la "vivencia profunda" que ambos textos visuales dejan en su lector.

En conclusión, hemos visto algunas de las estrategias que emplea José Lezama Lima en sus ensayos sobre artes plásticas. Entre ellas destacamos la preponderancia del elemento óptico gracias a la palabra que busca desplegar los atributos del lenguaje pictórico y la presencia de una constante ficcionalización en la historia y en la crítica de las expresiones visuales. Justamente es la centralidad de este elemento ficcional, la que unida a un lenguaje poético rico en metáforas e imágenes, conduce a una marcada ambigüedad, una indeterminación a la que nos aproximamos desde múltiples miradas y que representó el eje de nuestra investigación. 


\section{Galería de imágenes}

La galería, como empalizada del bambú aporético de las imágenes, representa una raíz de cultura, cuyas vicisitudes y rectificaciones pertenecen al espíritu secreto pero dueño de sus operaciones. Una galería antes de ser cultura es naturaleza, es decir, representa los avances de una vivienda tan sumergida como hierática, que avanza con pasos inaudibles y con inefables preferencias, hasta alcanzar un crujimiento de la tierra favorablemente signada y una luz que se decide. El fiel de una galería es así como una mágica ambivalencia entre el secreto potencial, la mañana sin espejos historiados, y la ciudad que entreabre sus cien puertas para establecer el contorno de resguardo frente a la Gorgona oprimida melodiosamente por el dios del río.

José Lezama Lima 


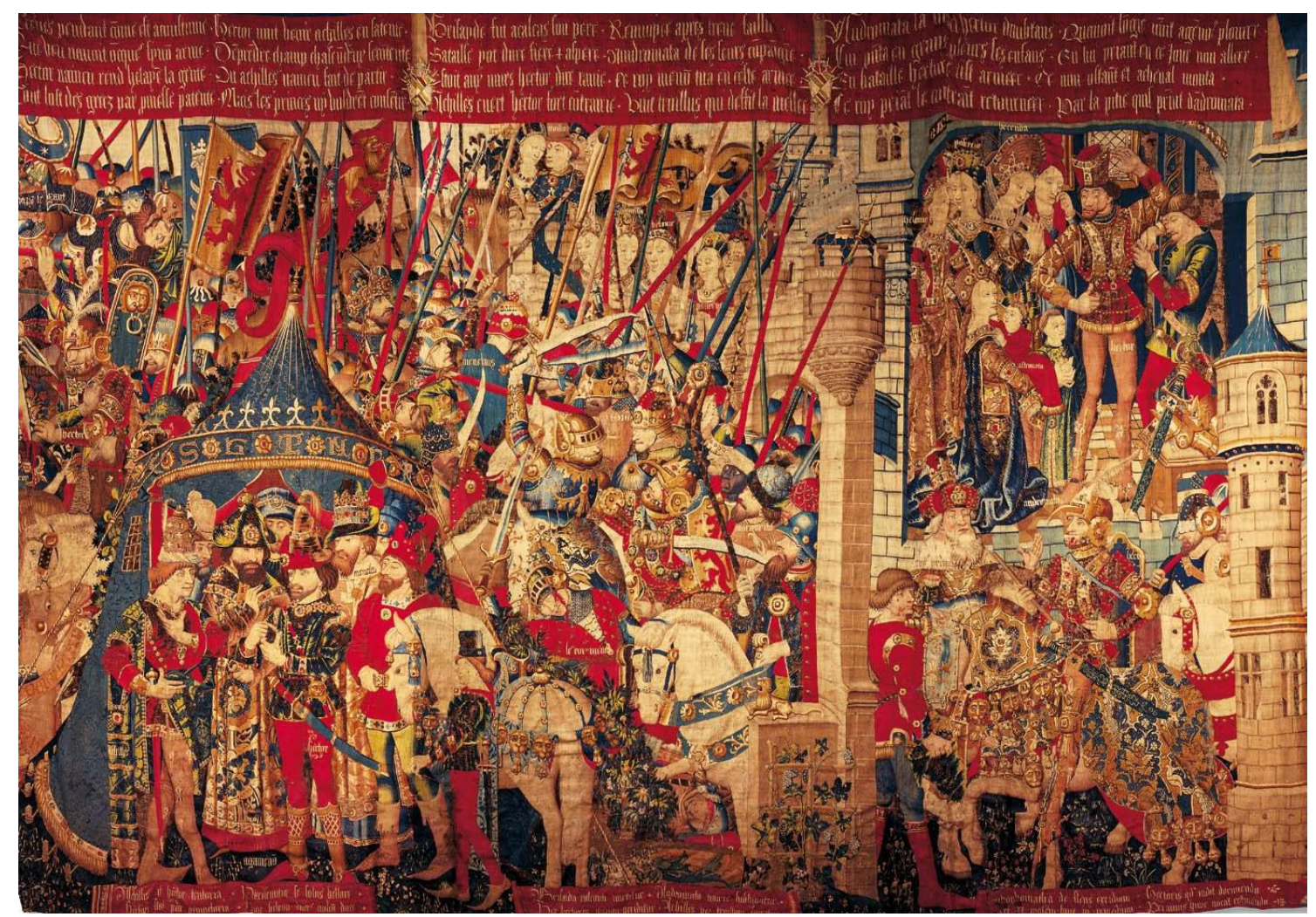

Figura 1. Tapiz de Zamora. Escena de Aquiles (tapiz tejido em Tournay hacia 1470)

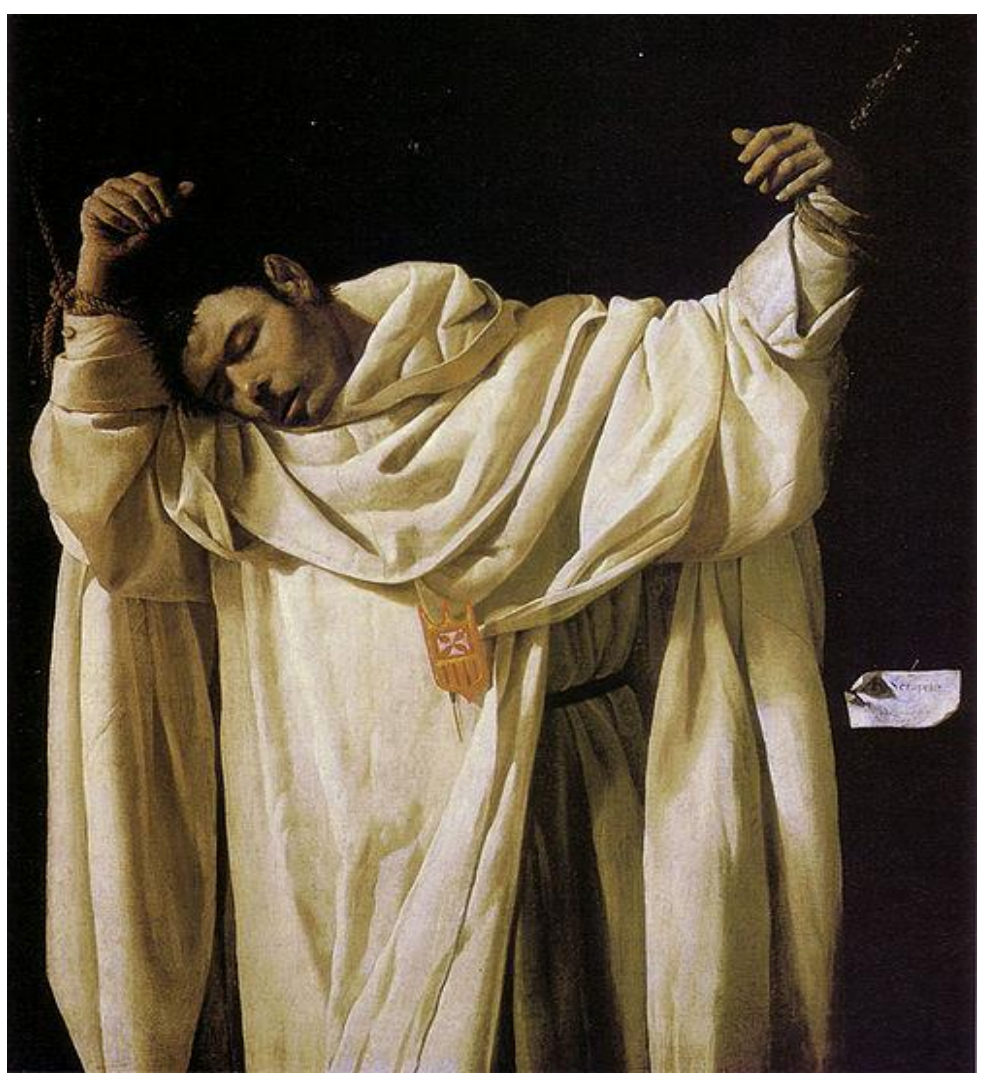

Figura 2. San Serapio (1628). Francisco de Zurbarán 


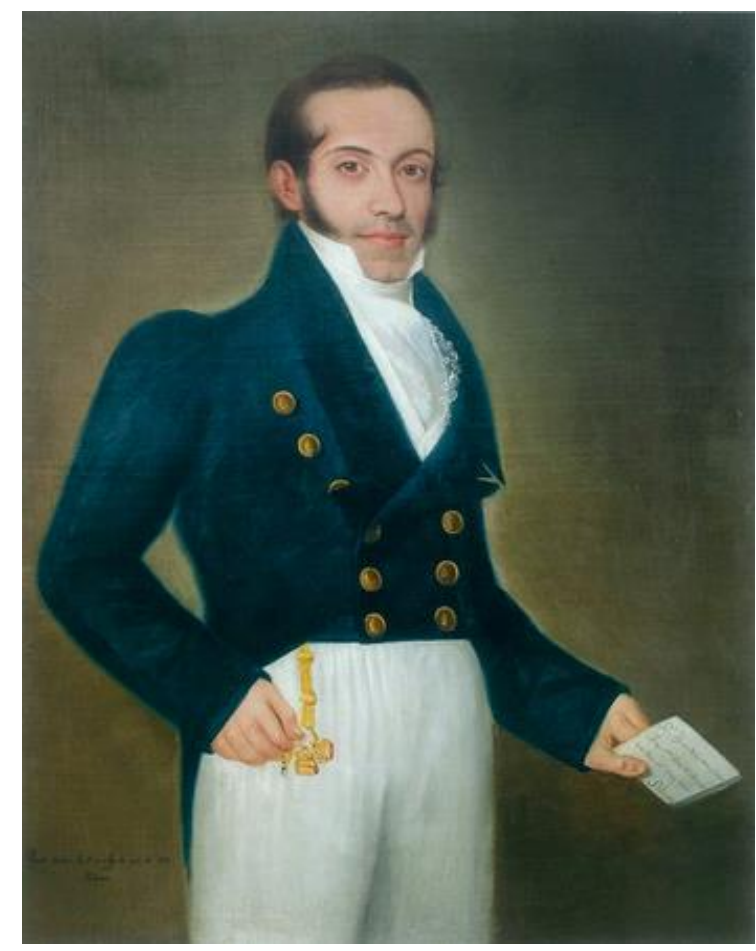

Figura 3. Don Agustín de las Heras (1828). Vicente Escobar

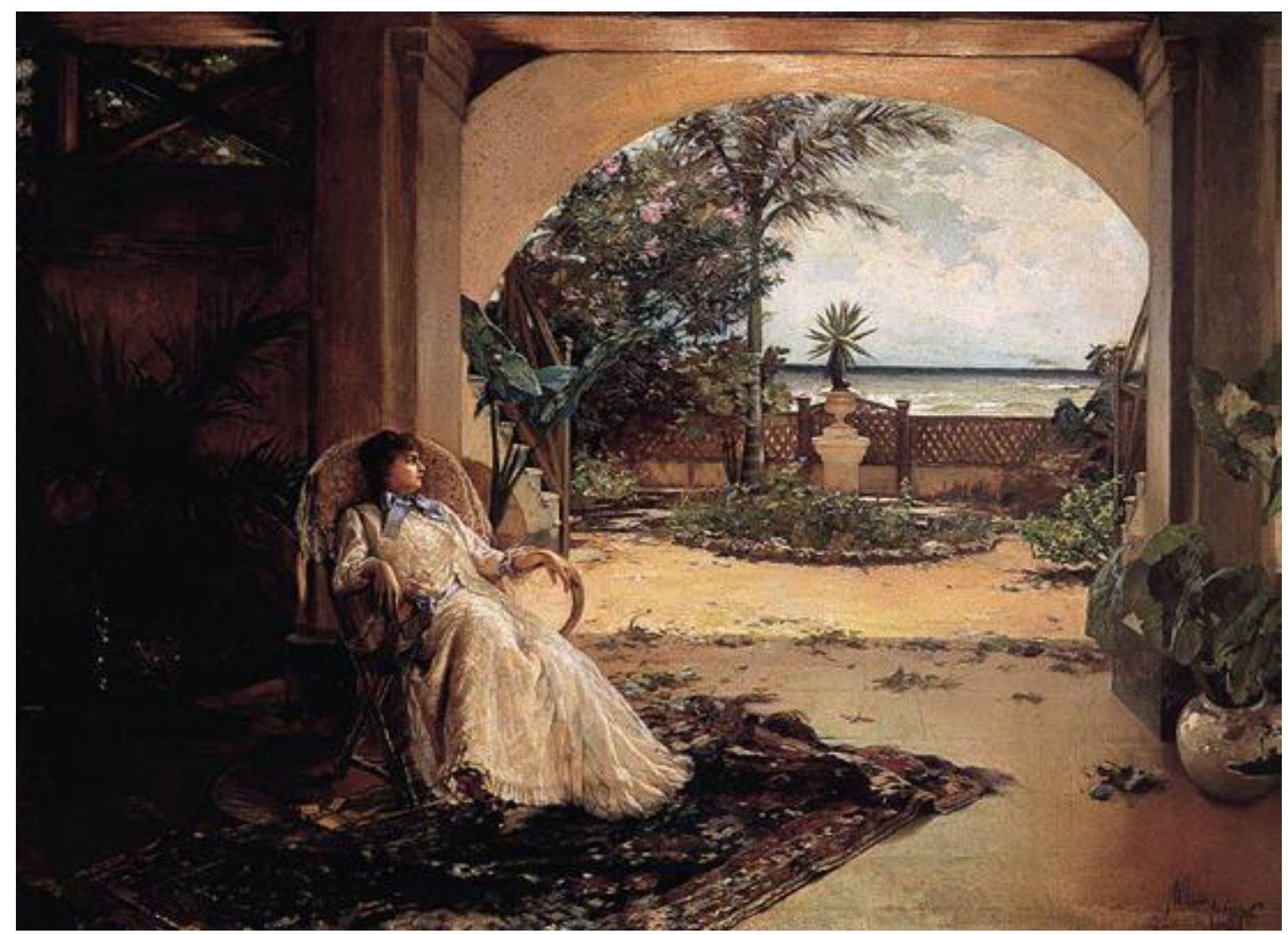

Figura 4. La siesta (1888). Guillermo Collazo 


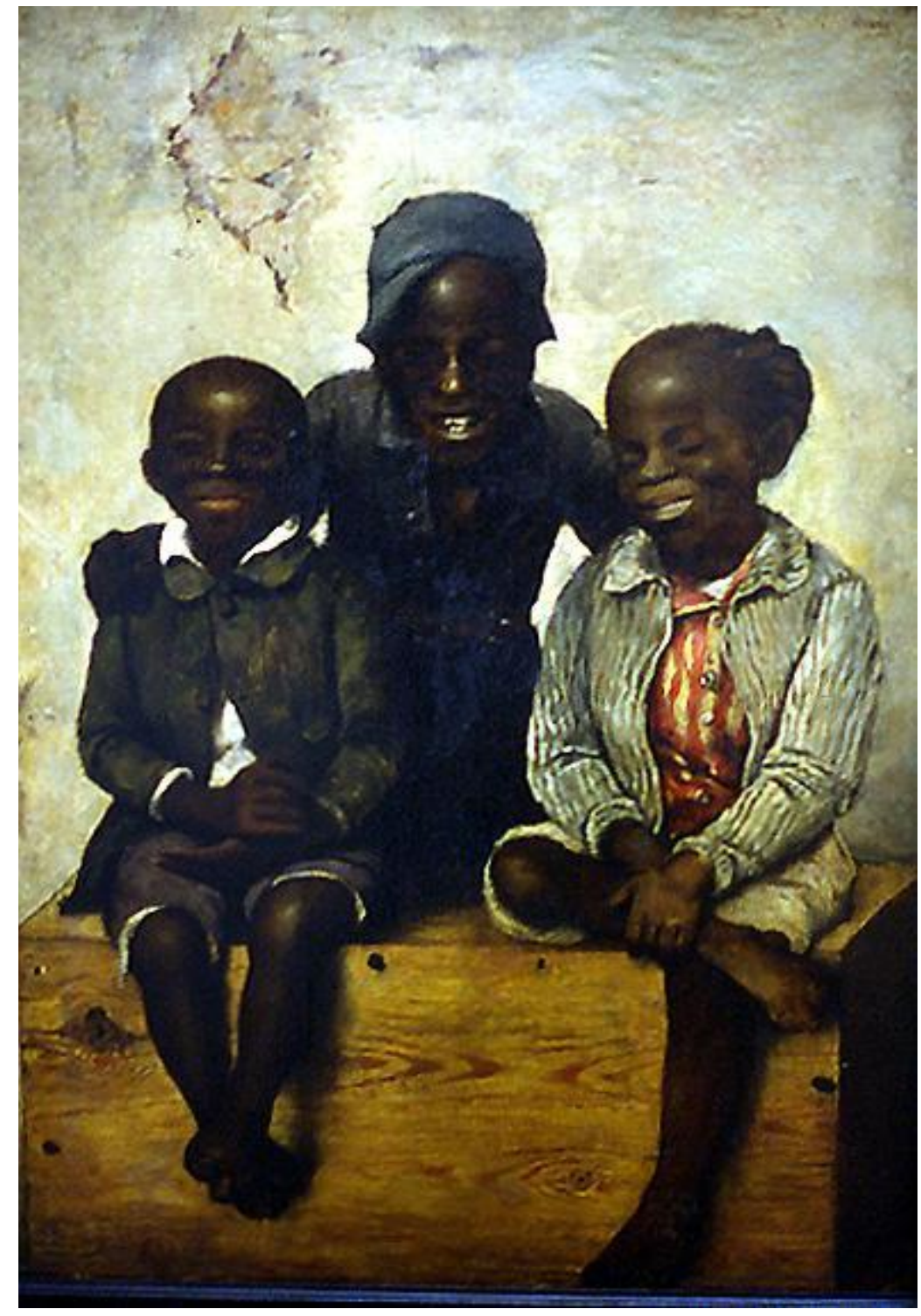

Figura 5. Los pilluelos (1896). Juana Borrero

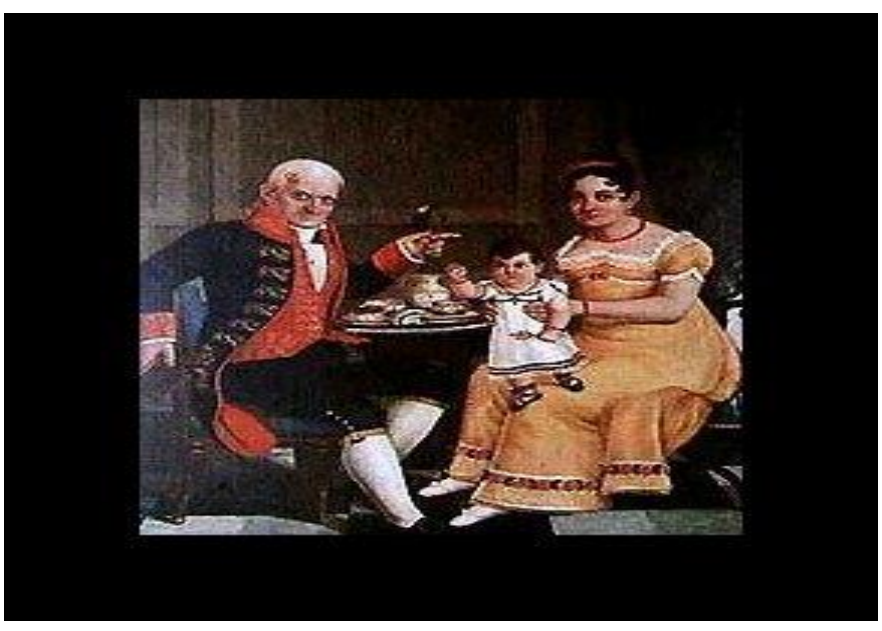

Figura 6. La familia Manrique Lara (1812). Jean Baptiste Vermay 


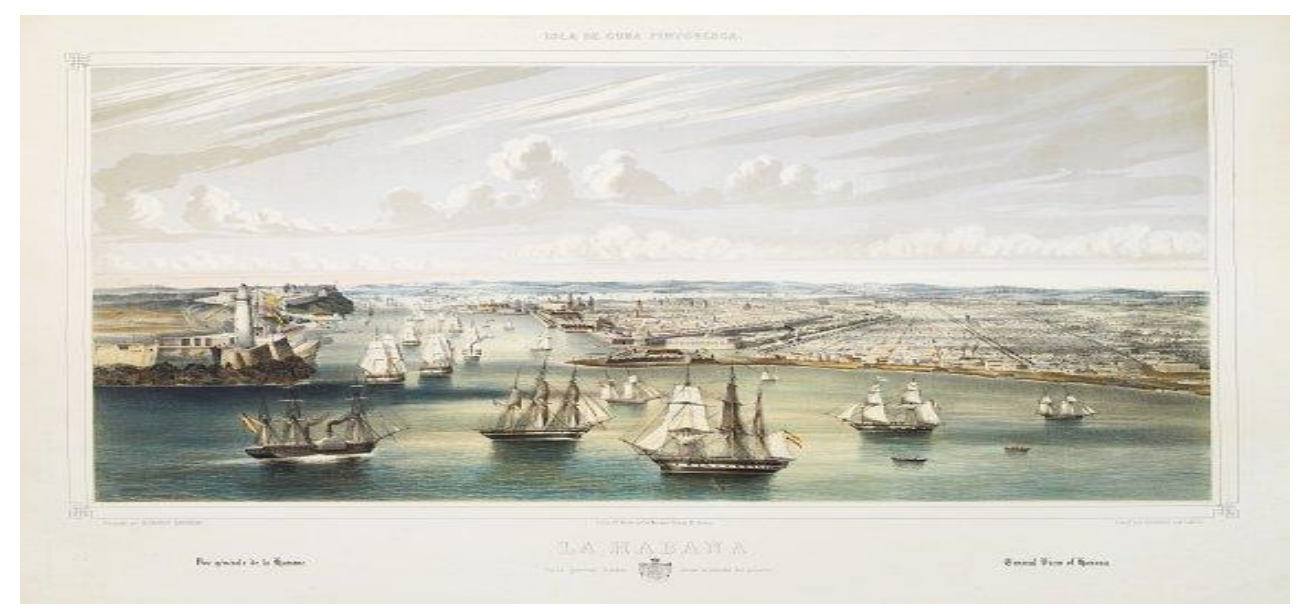

Figura 7. Vista General del Puerto de la Habana (hacia 1858). Barañano

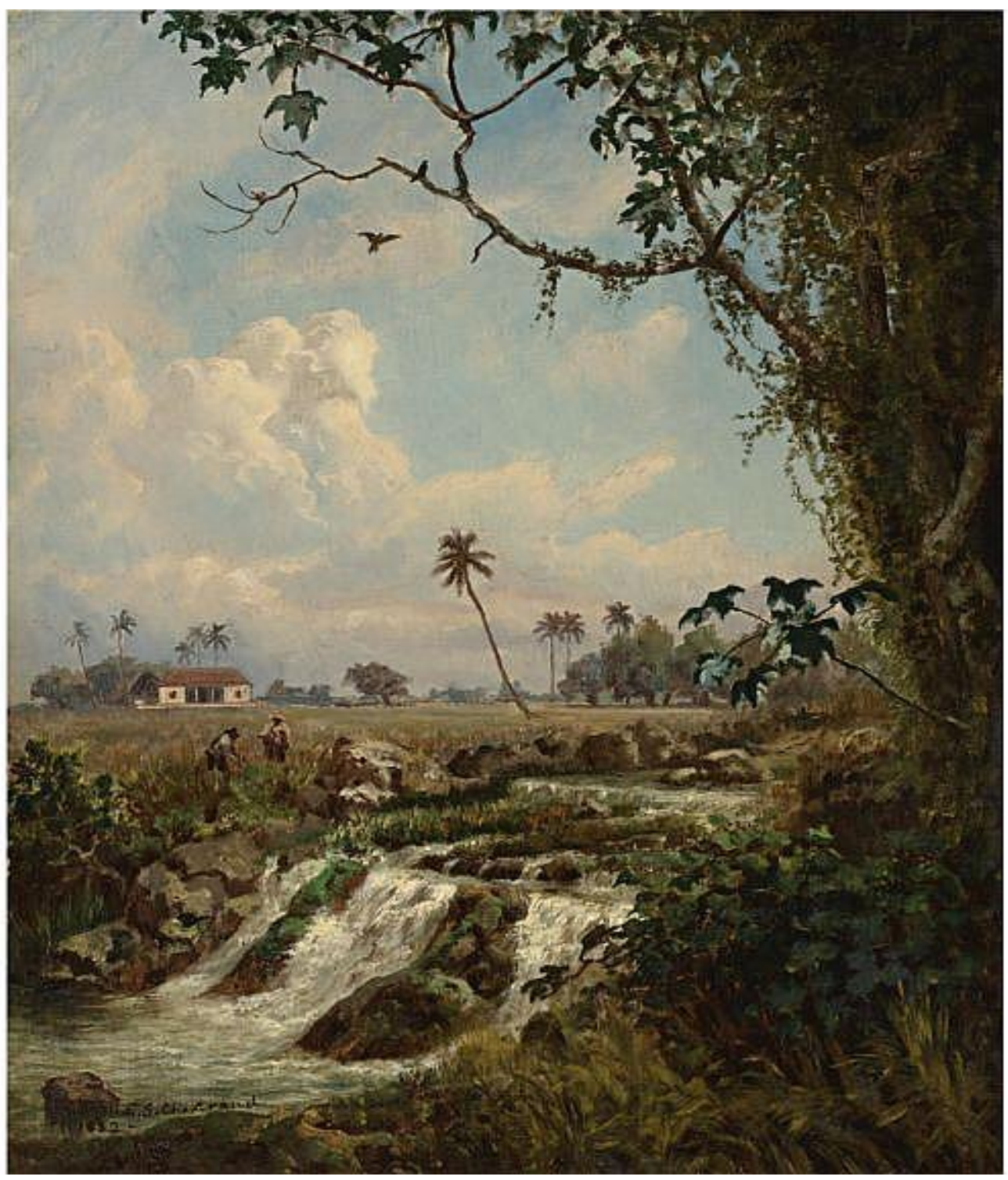

Figura. 8. Paisaje con campesinos (1882). Esteban Chartrand Dubois 


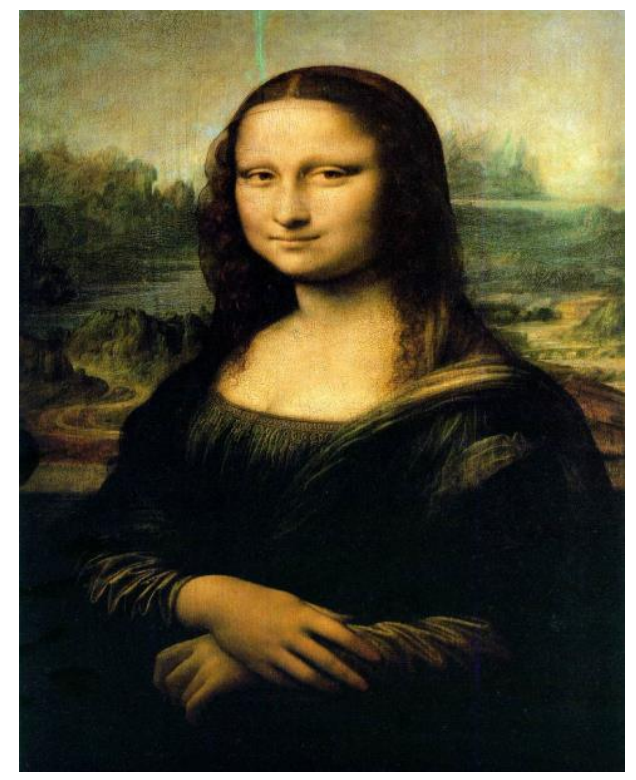

Figura 9. Gioconda (1503-1506). Leonardo Da Vinci

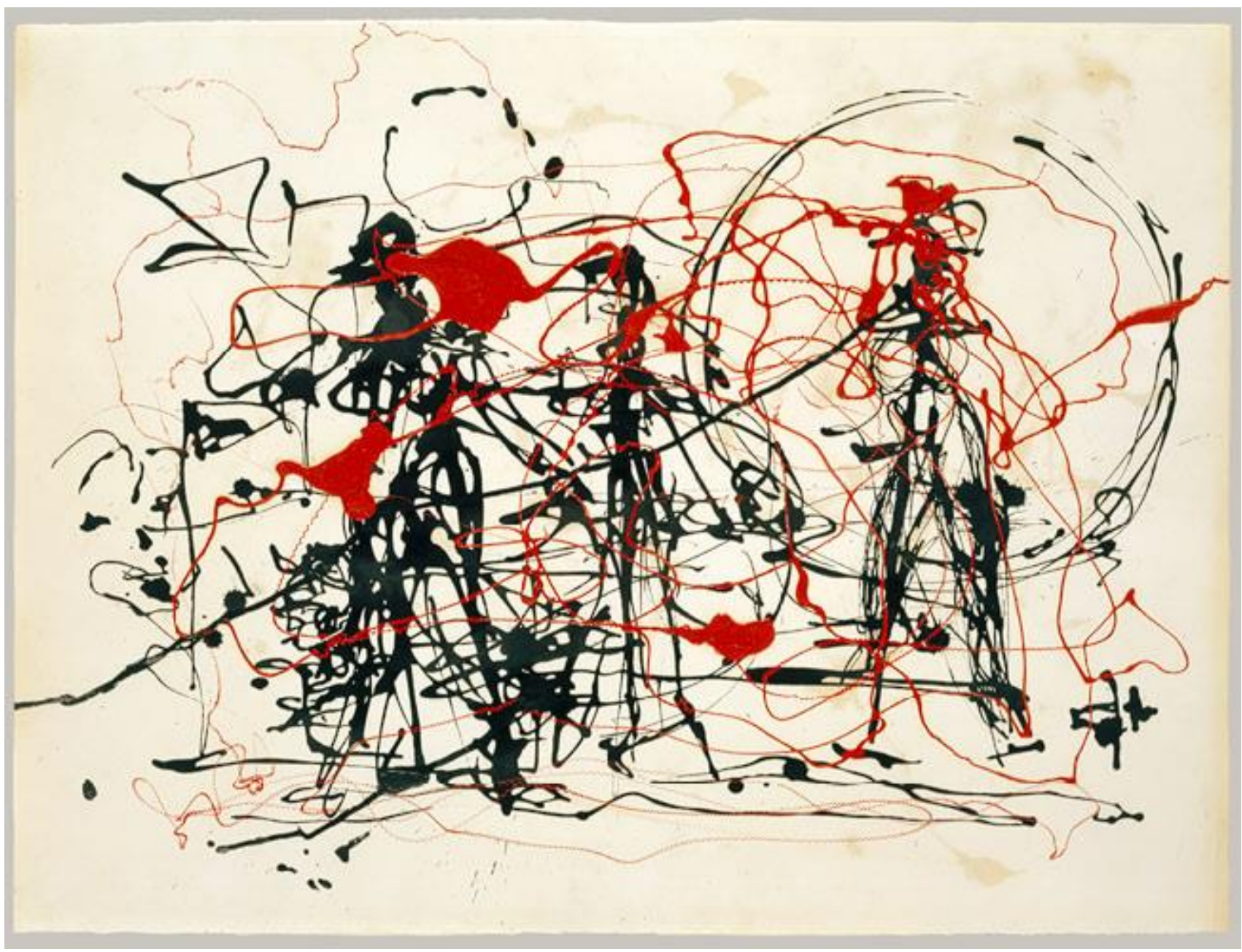

Figura 10. Sin título (1948-1949). Jackson Pollock 


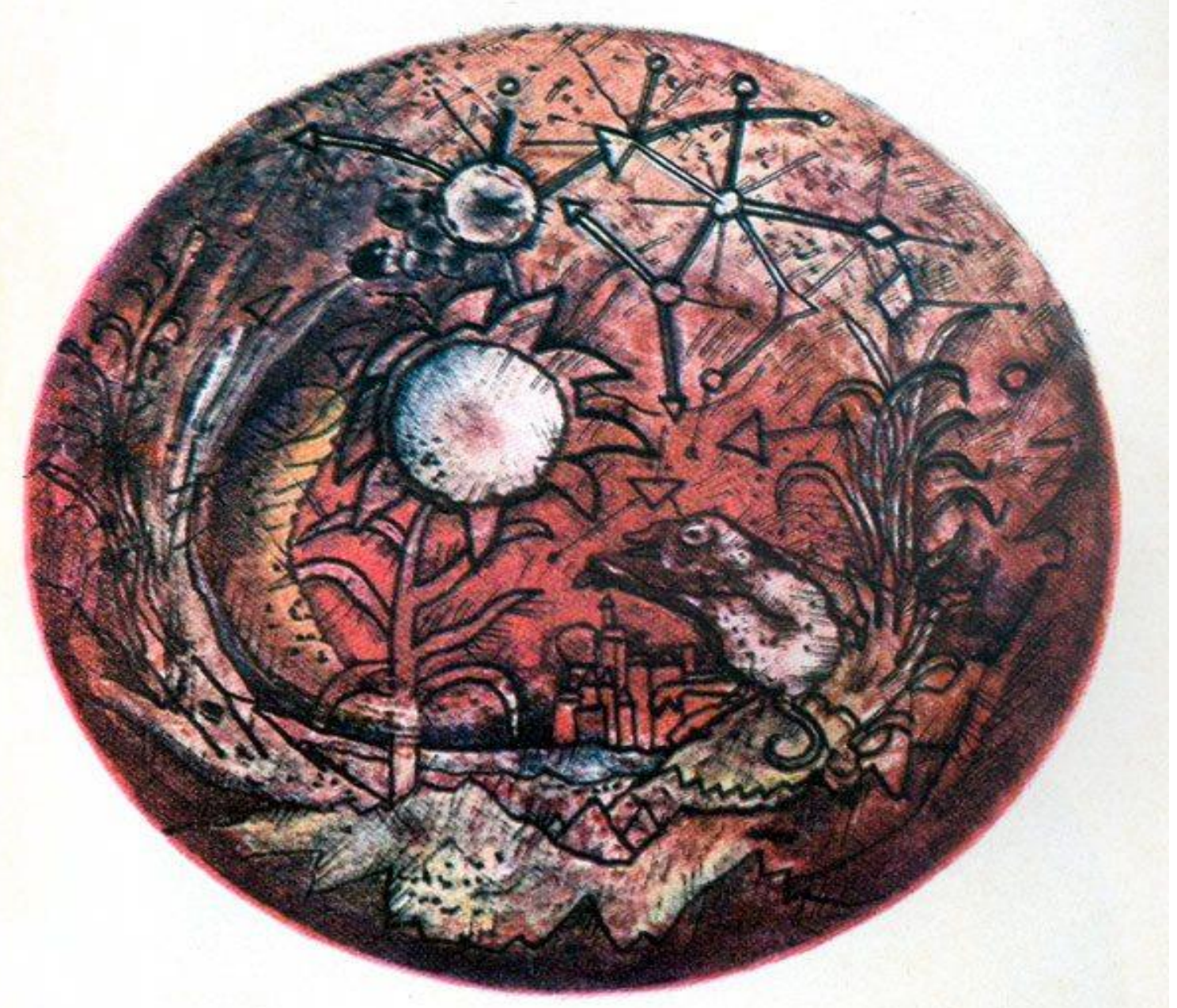

Figura 11. En esta tierra, 1, (1959). Fayad Jamís.

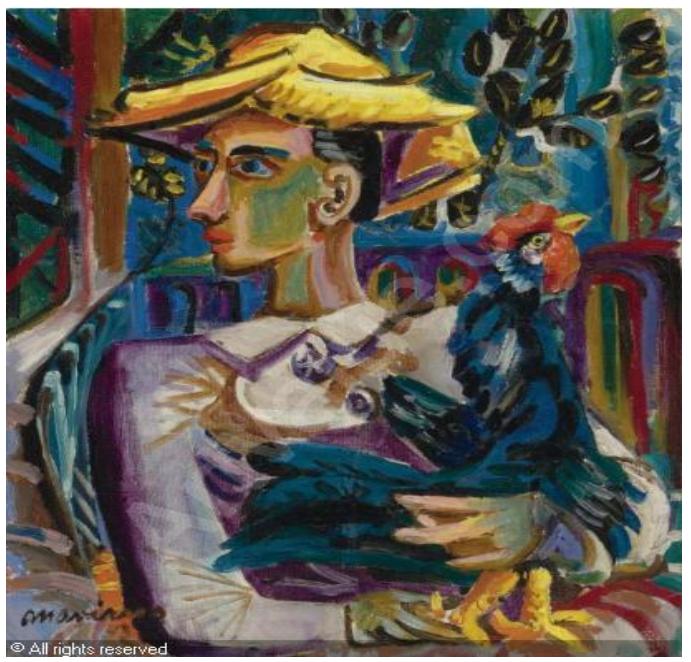

Figura 12. Guajiro con gallo (1943). Mariano Rodríguez 


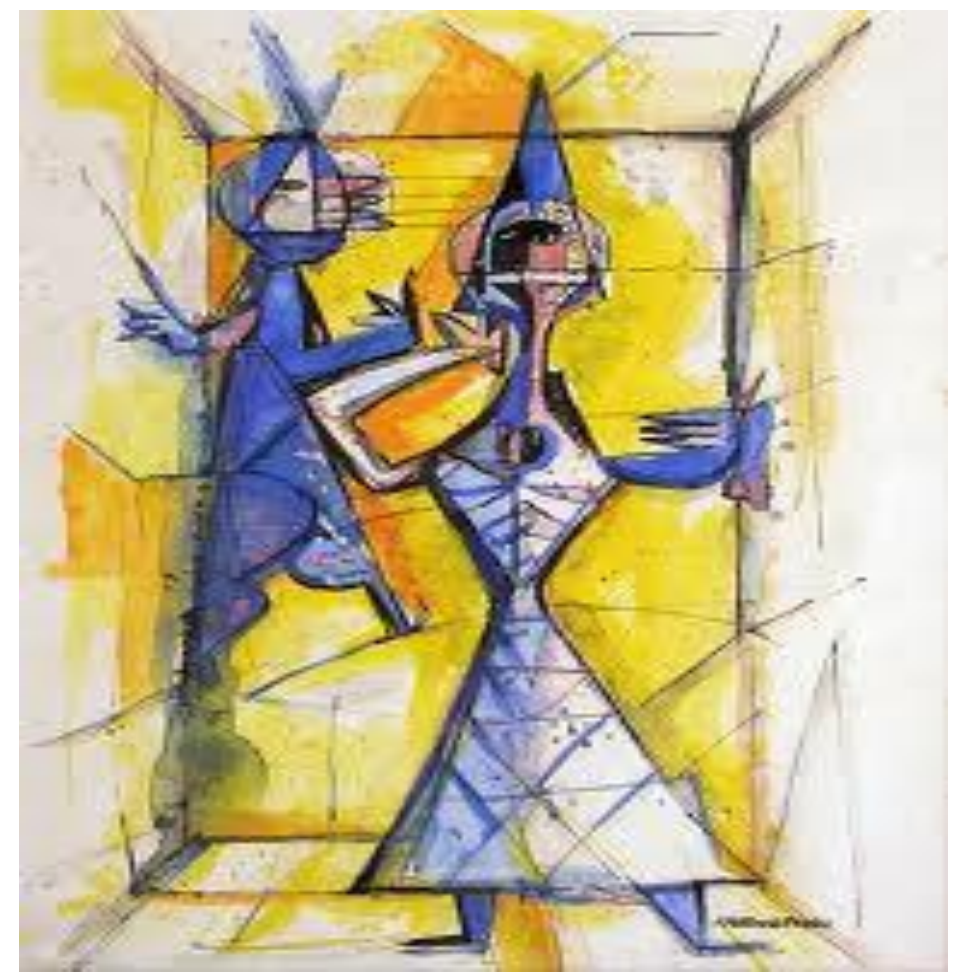

Figura 13. Figuraciones (1946). Luis Martínez Pedro

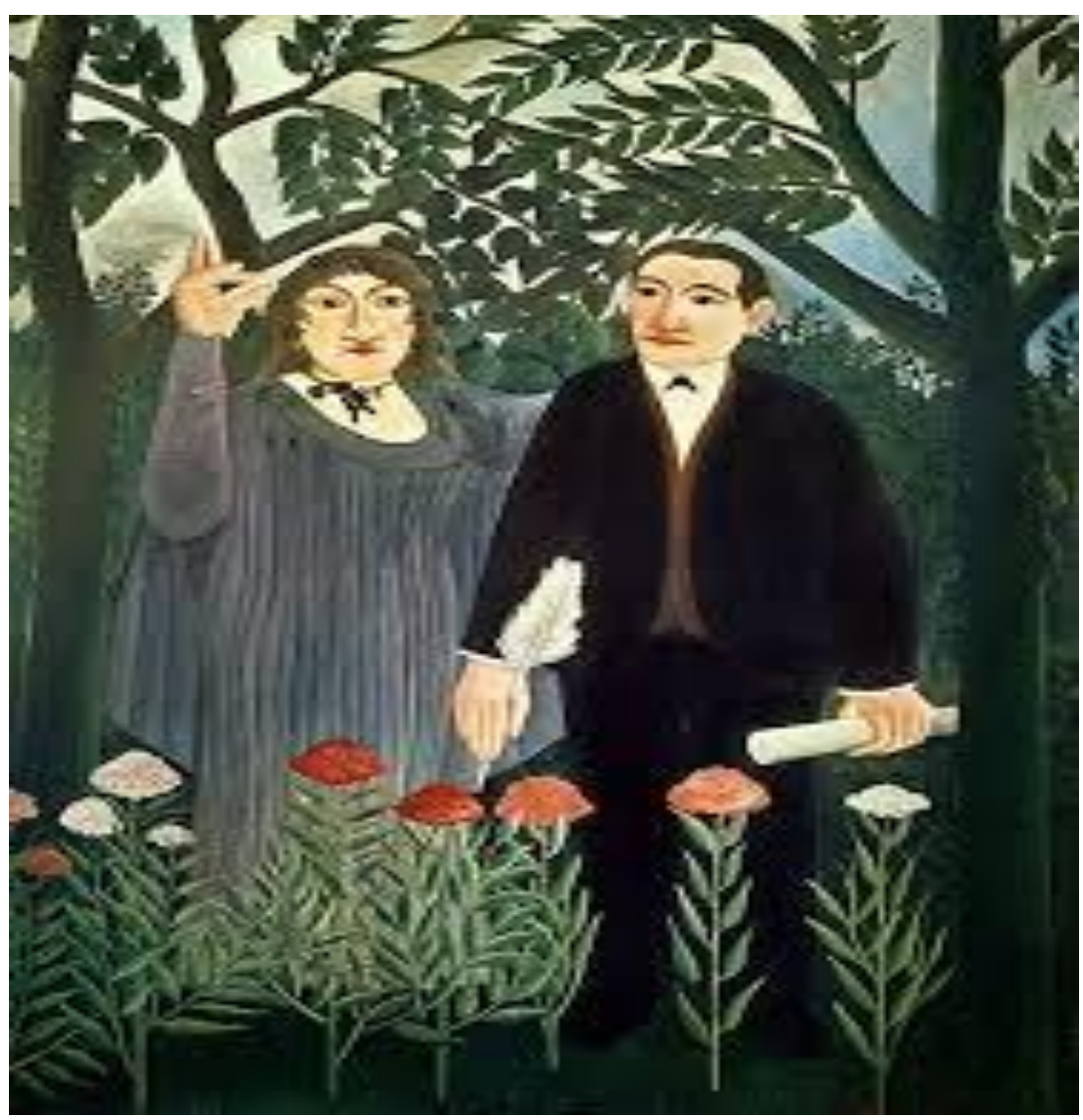

Figura 14. La musa inspira al poeta (1909). Aduanero Rousseau 


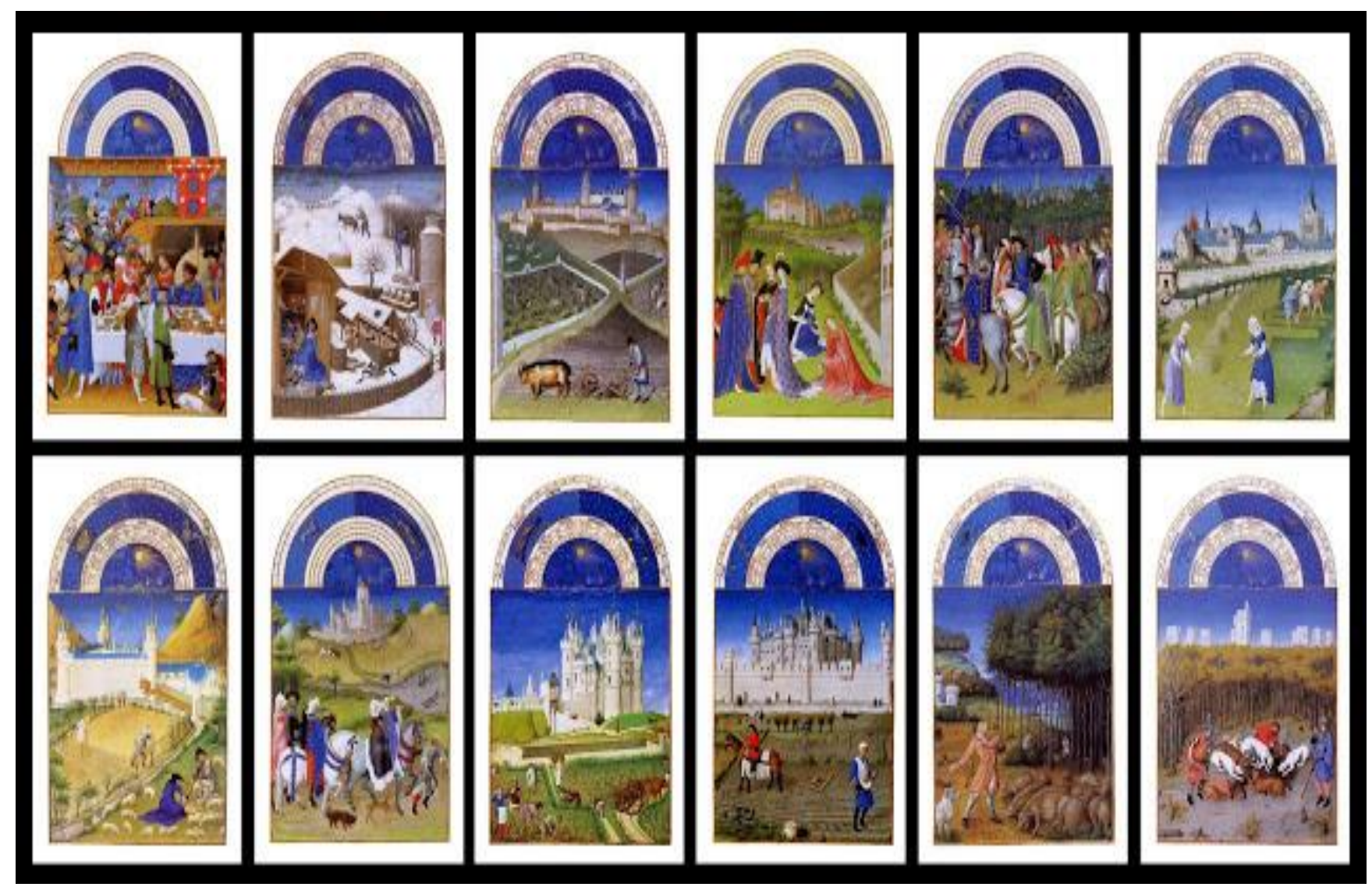

Figura 15. Libro de horas del Duque de Berry (1410). Anónimo

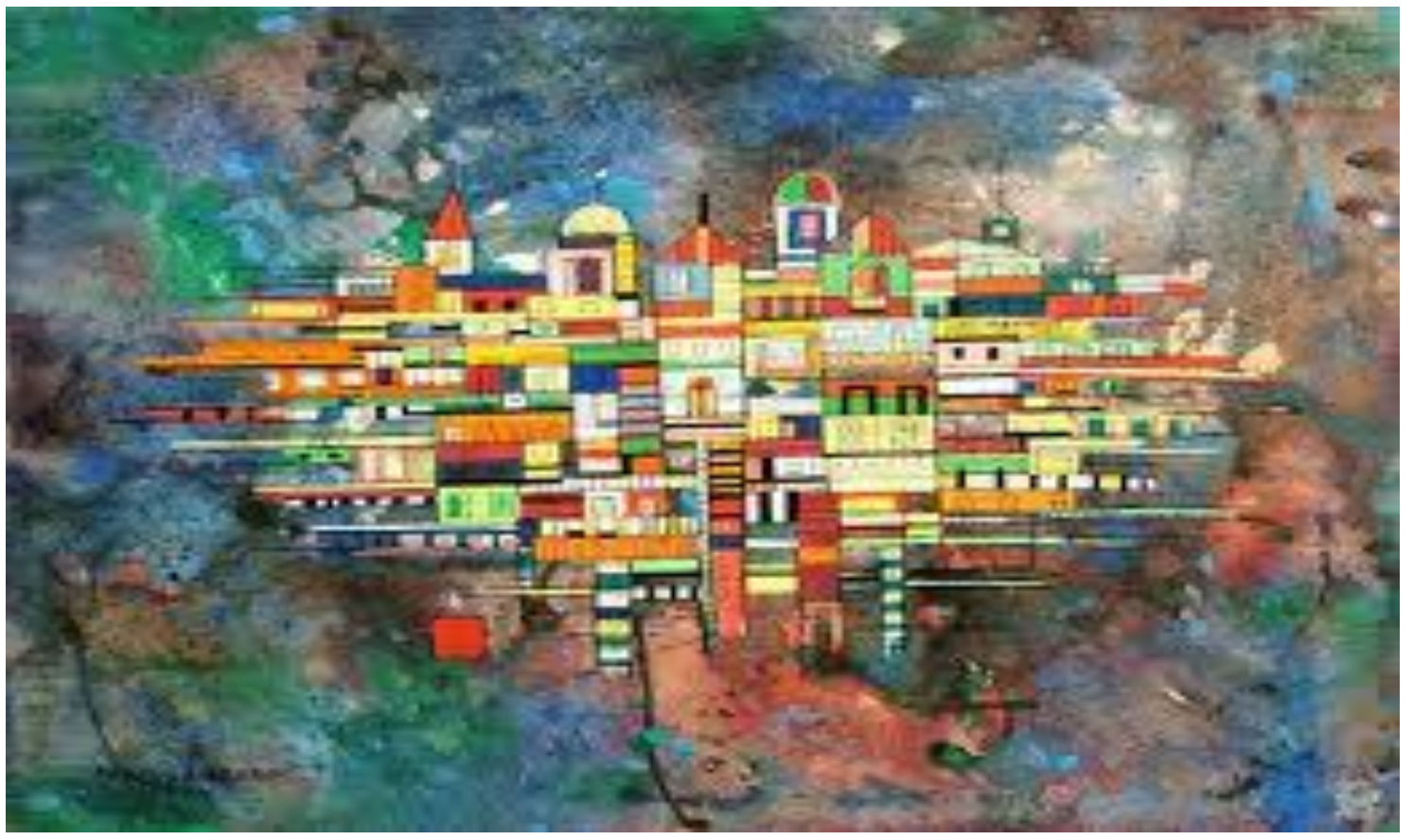

Figura 16. La ciudad (1950). René Portocarrero 


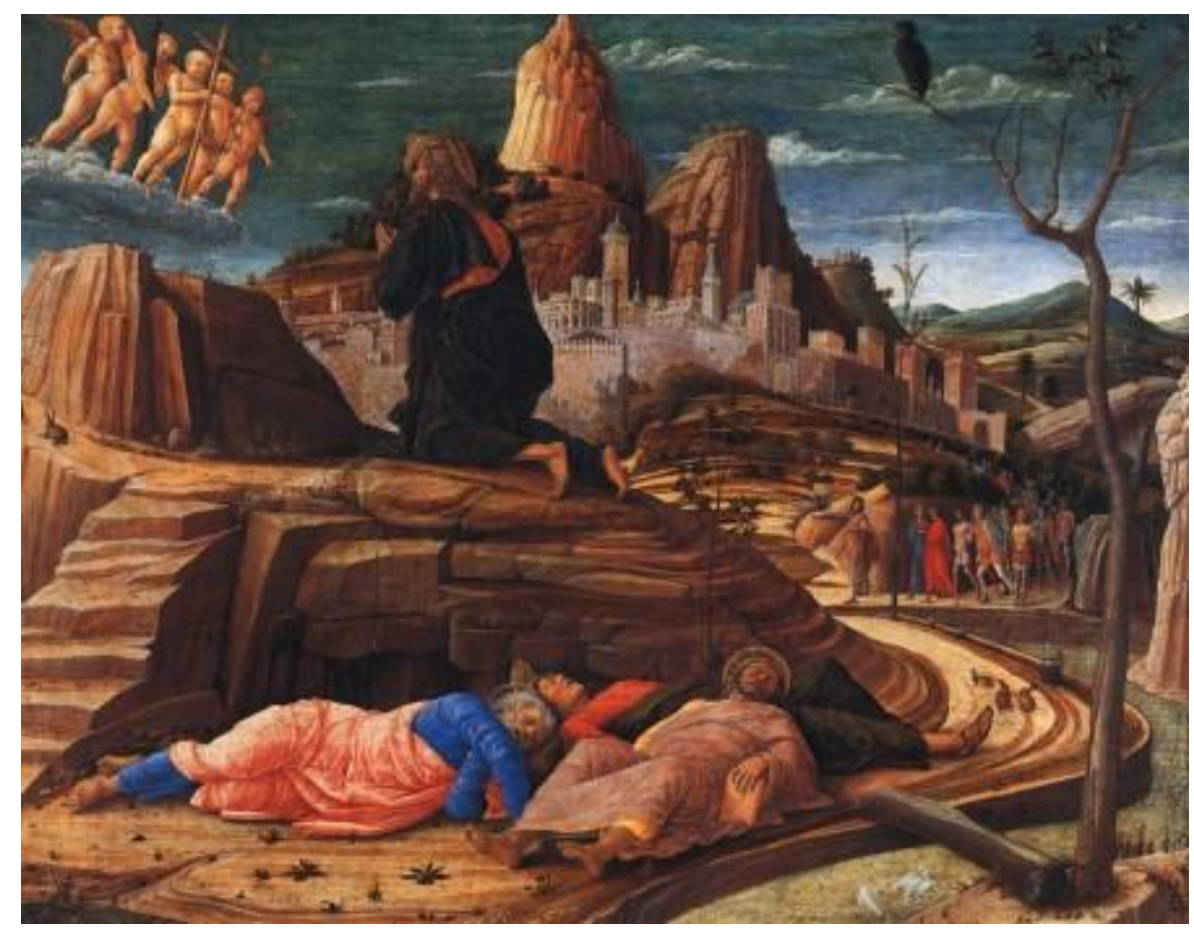

Figura 17. Escena del retablo para la Iglesia de San Zenón de Verona (1459). Andrea Mantegna

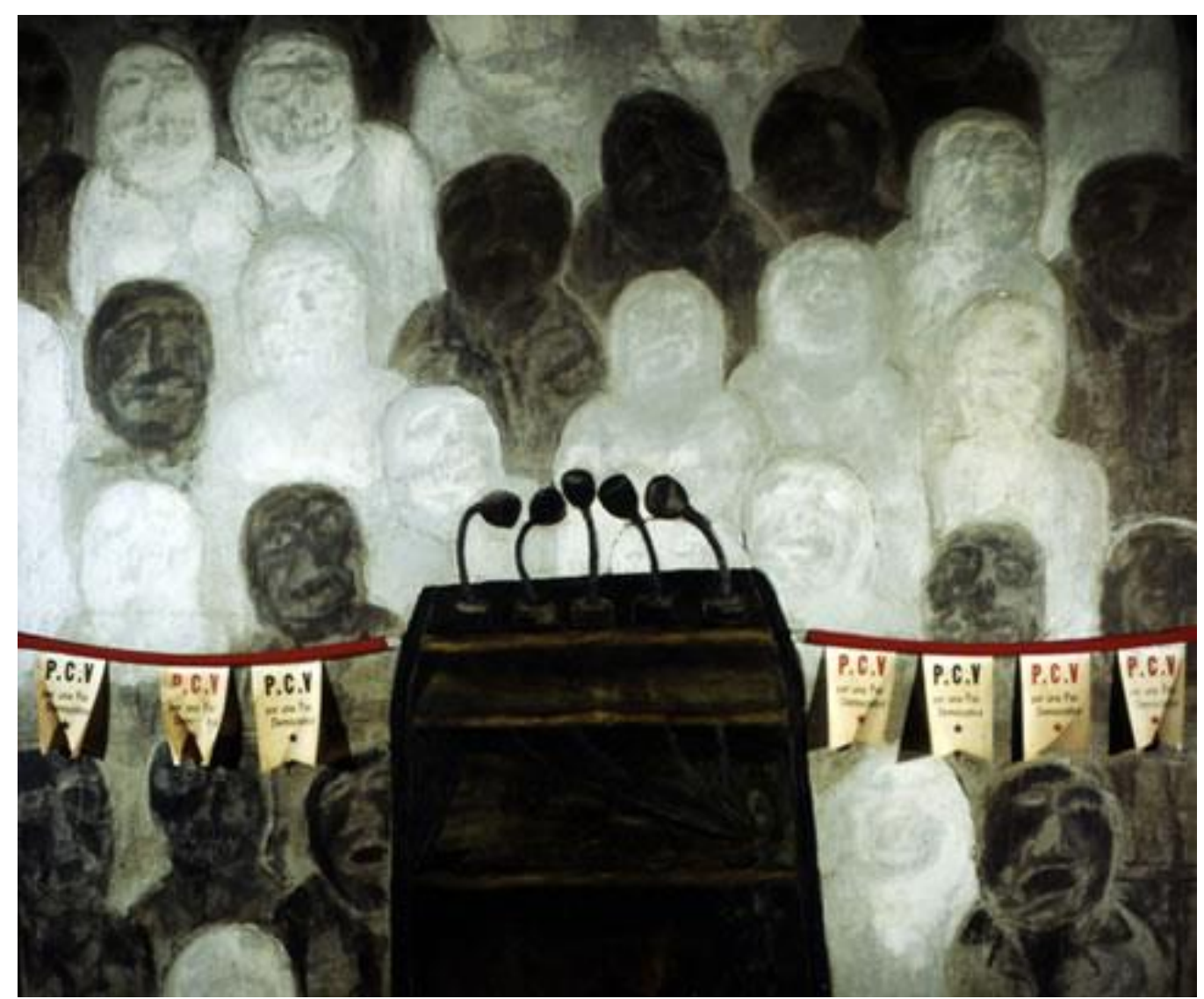

Figura 18. Una tribuna para la paz democrática (1968). Antonia Eiriz 


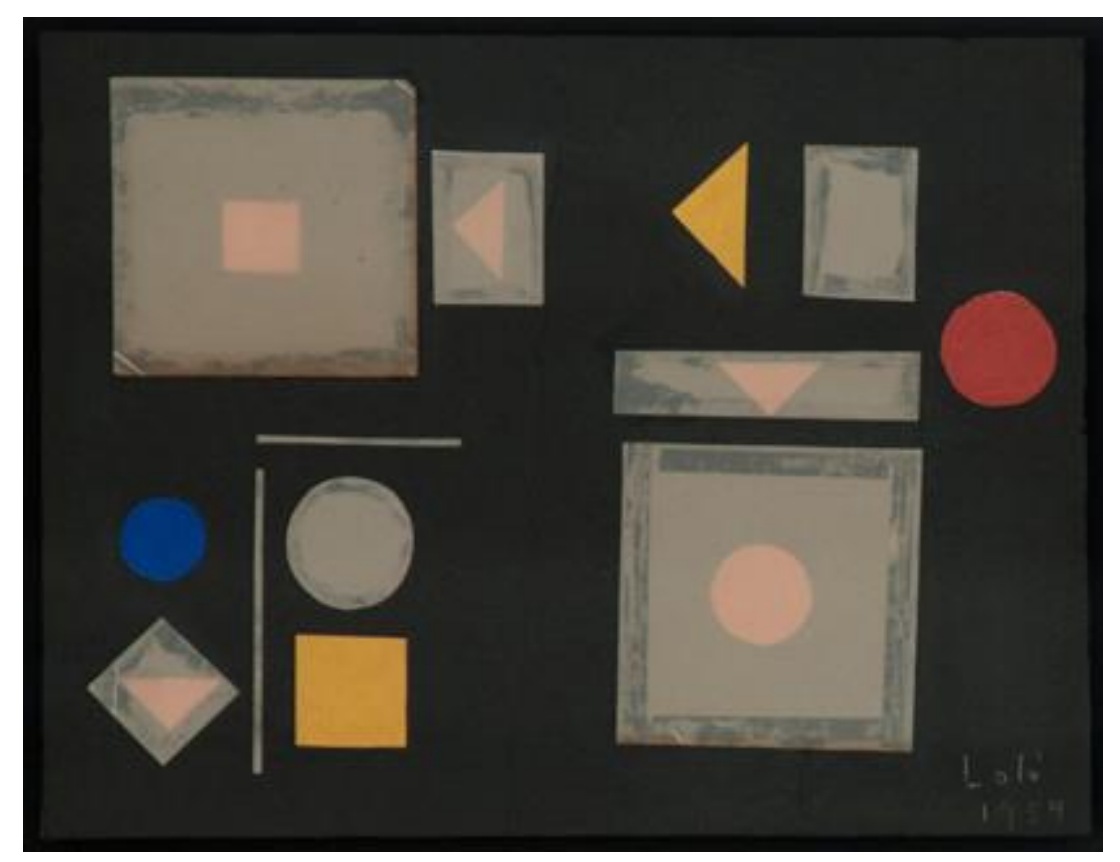

Figura 19. Untitled (1954). Dolores Soldevilla ("Loló”)
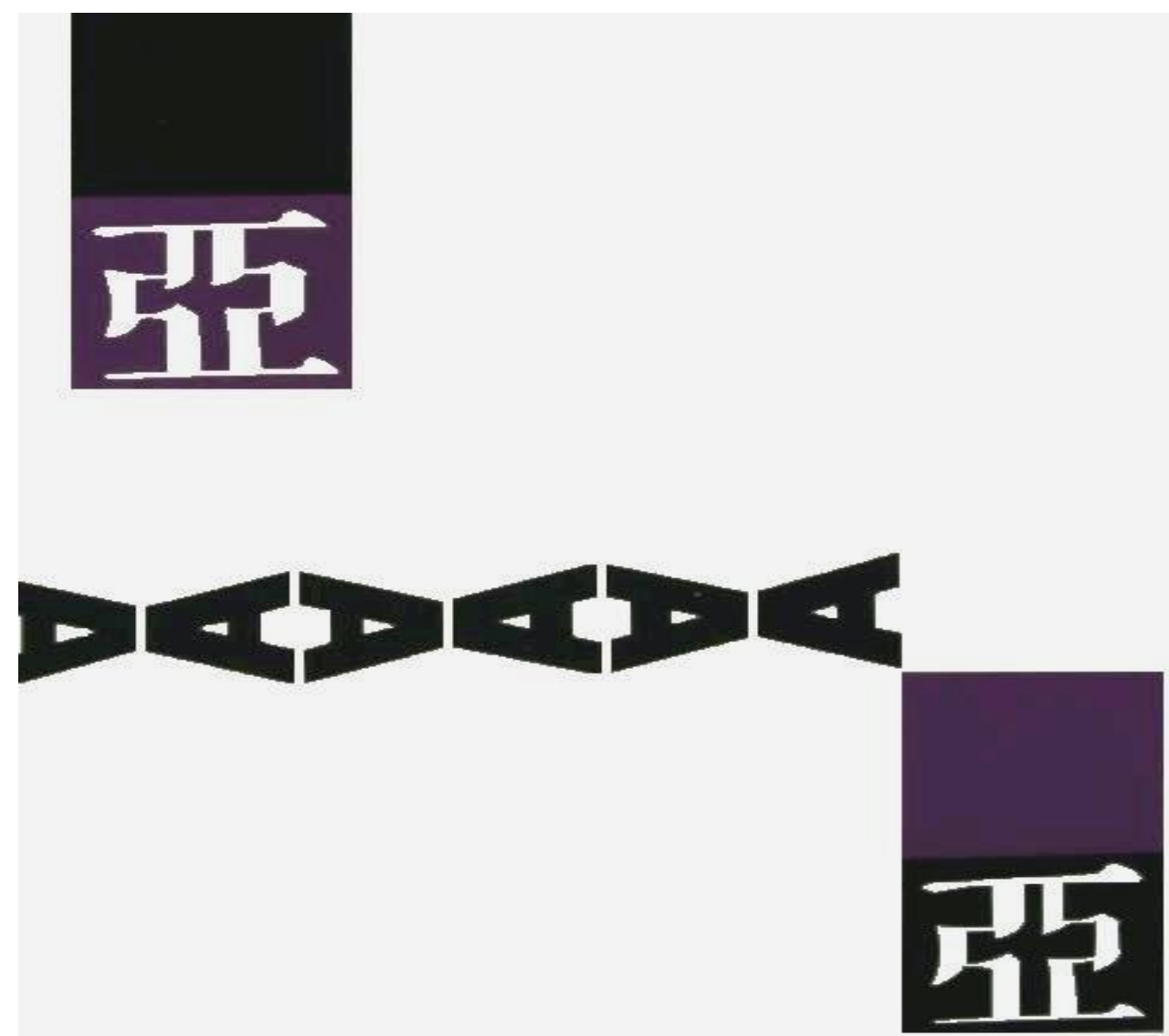

Figura 20. Letra A (1961). Salvador Corratgé 


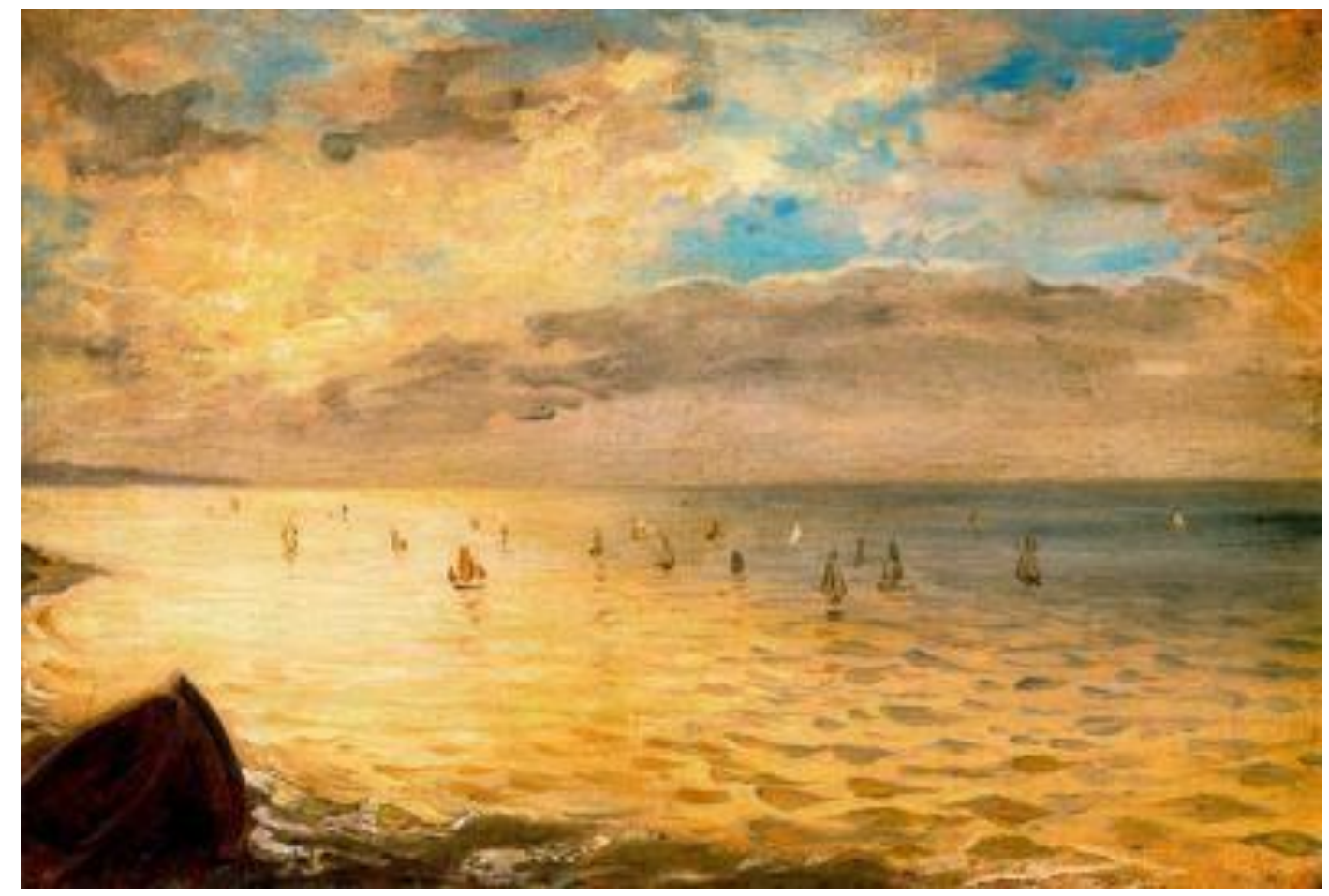

Figura 21. El mar desde las alturas del Dieppe (1852). Delacroix

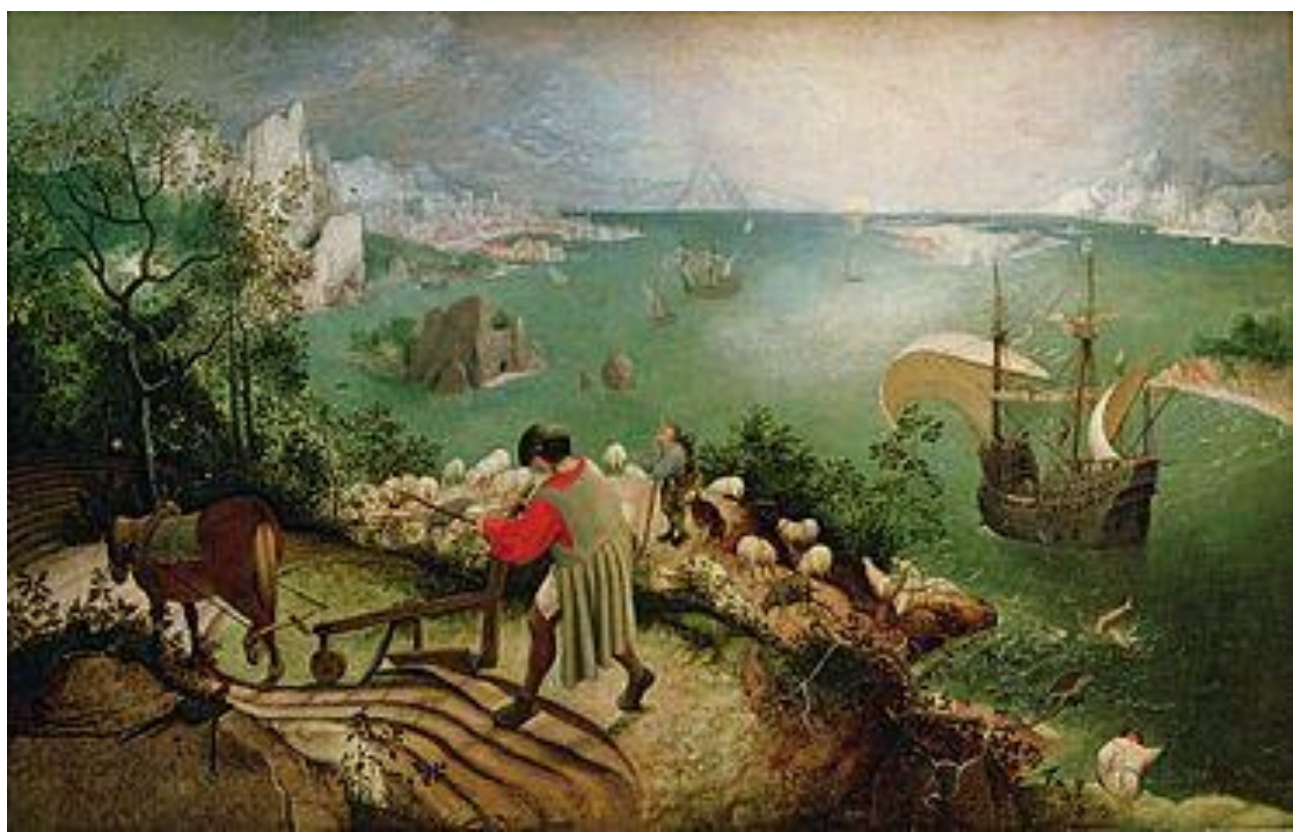

Figura 22. Paisaje con la caída de Ícaro (1560). Pieter Brueguel 


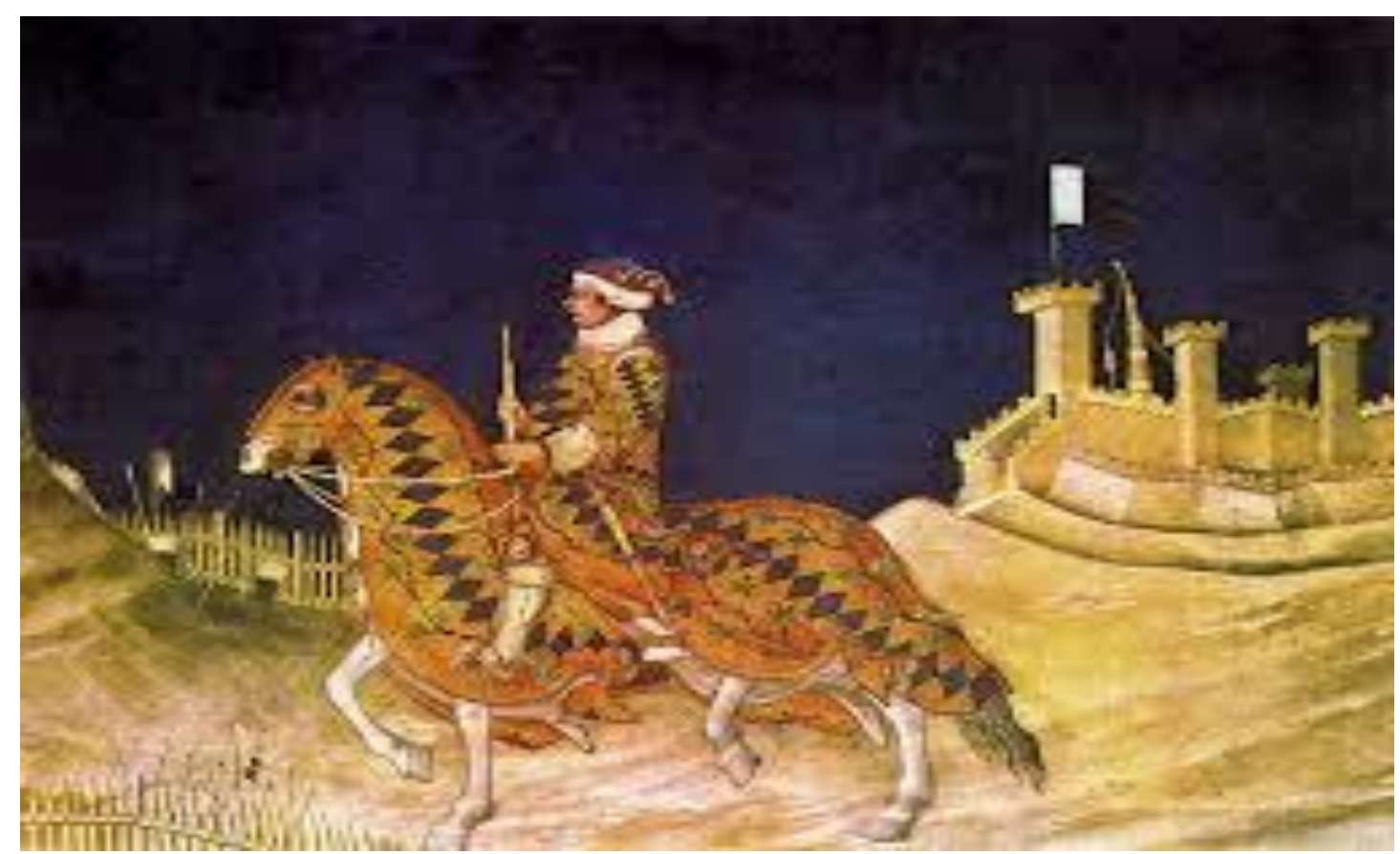

Figura 23. Guidoriccio da Fogliano (1328). Simone Martini

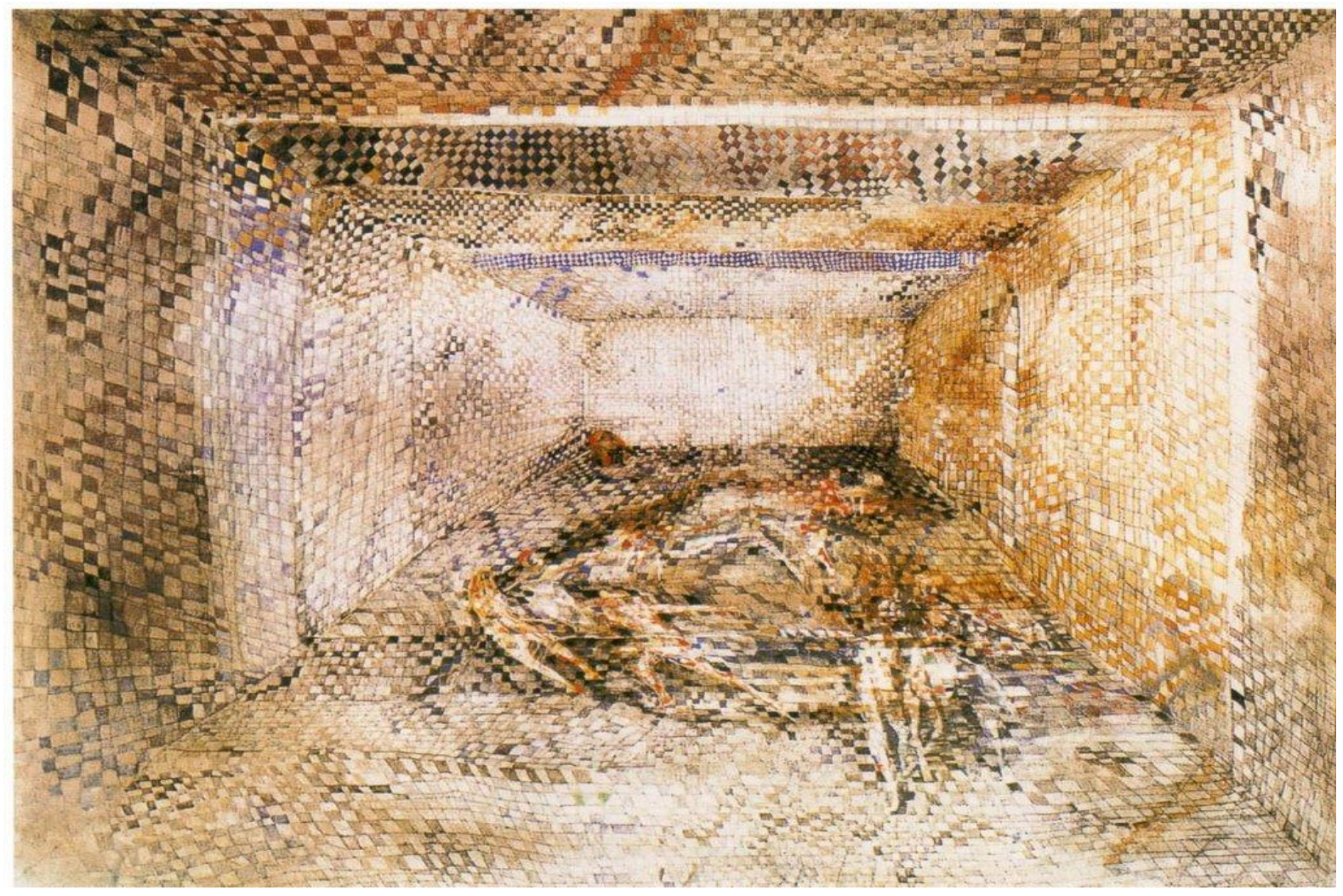

Figura 24. L'Atelier (1940). Maria Helena Vieira da Silva 


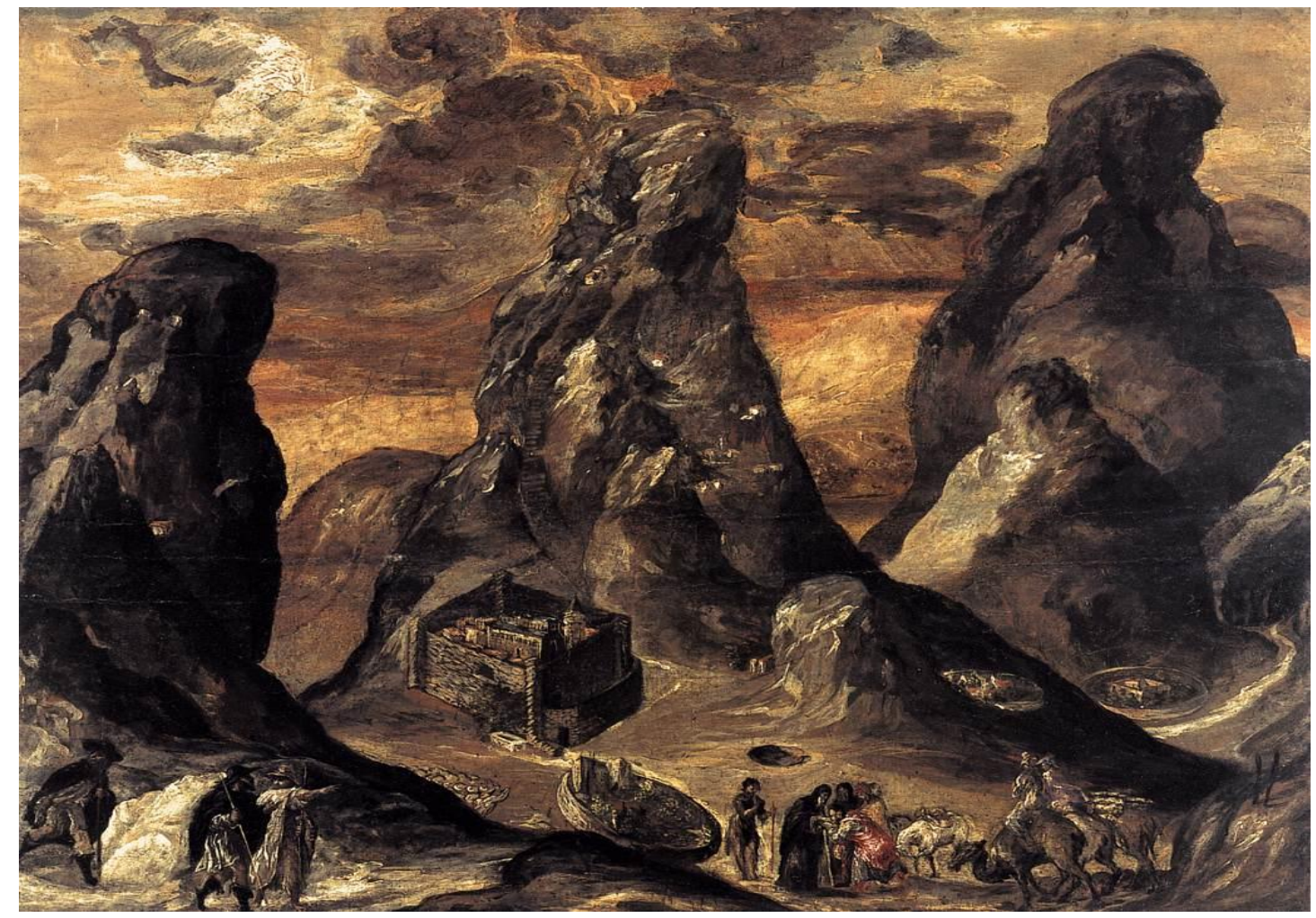

Figura 25. Monte Sinaí (1570). El Greco

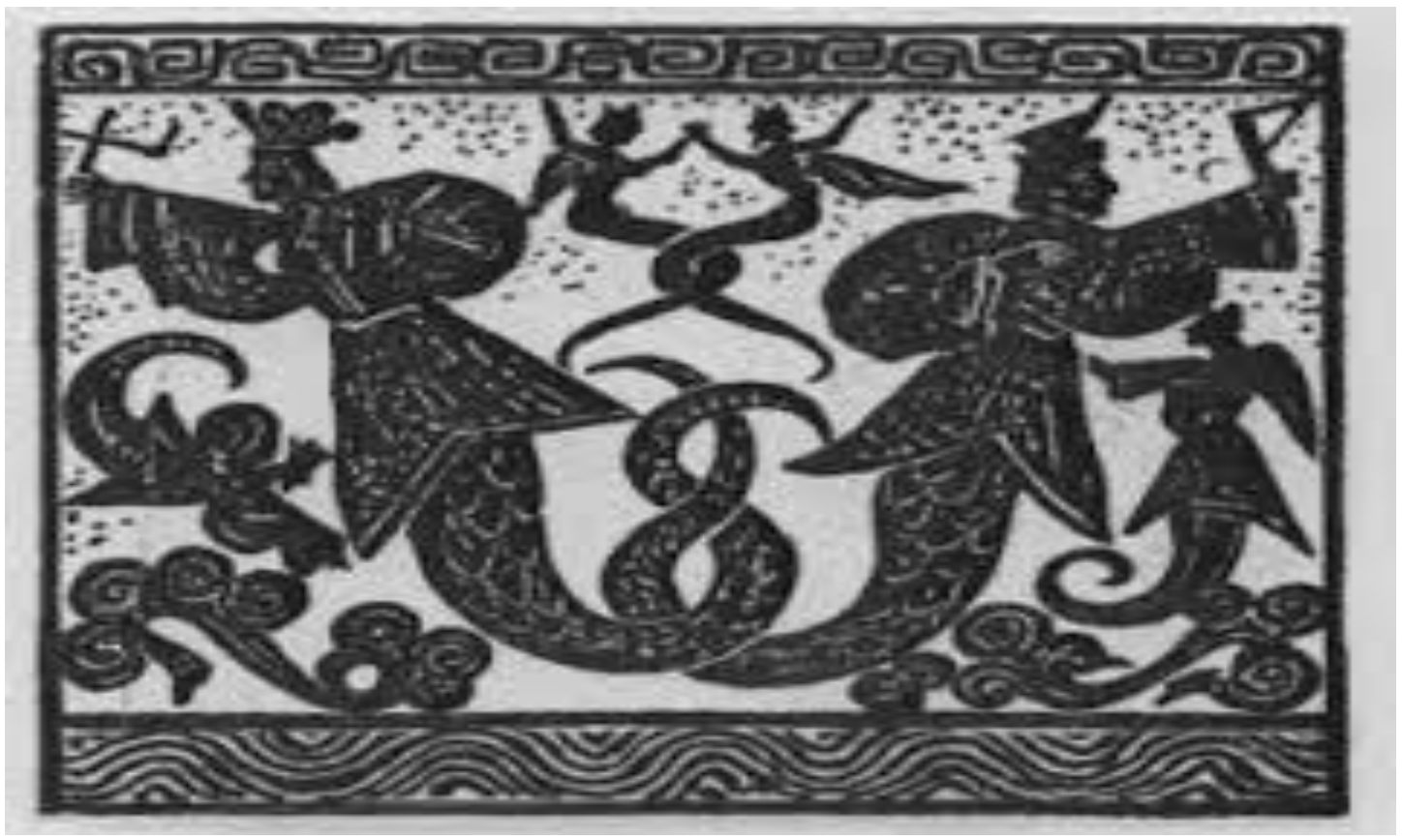

Figura 26. Fou Hi у Niи Kua. 


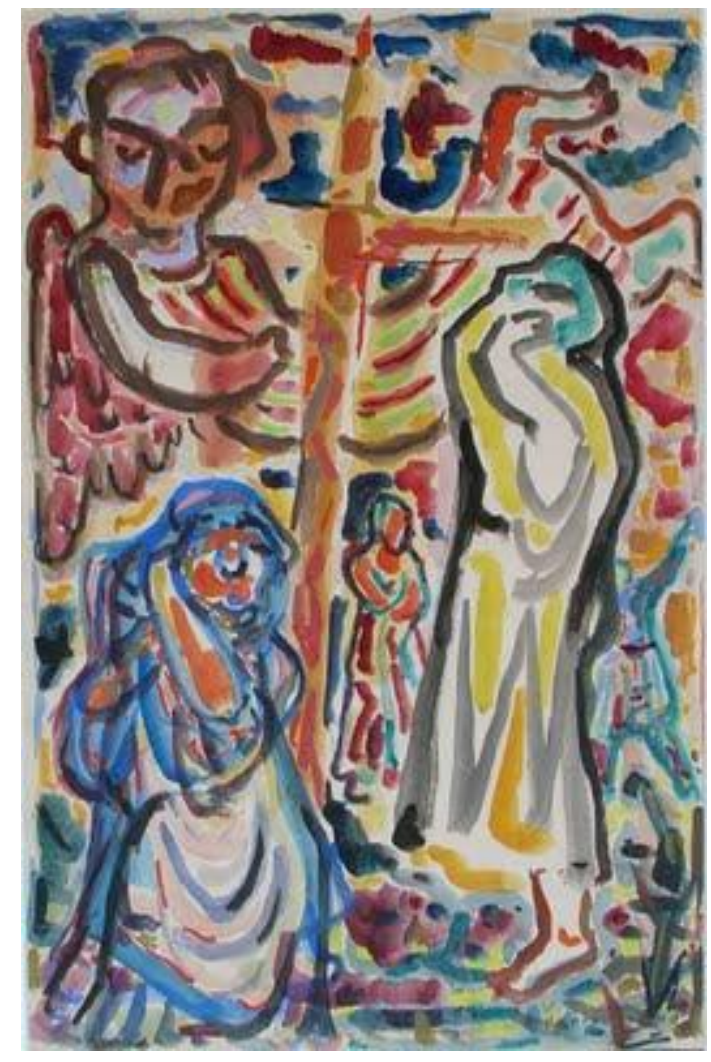

Figura 27. Crucifixión en la Iglesia de Bauta (1942). Portocarrero

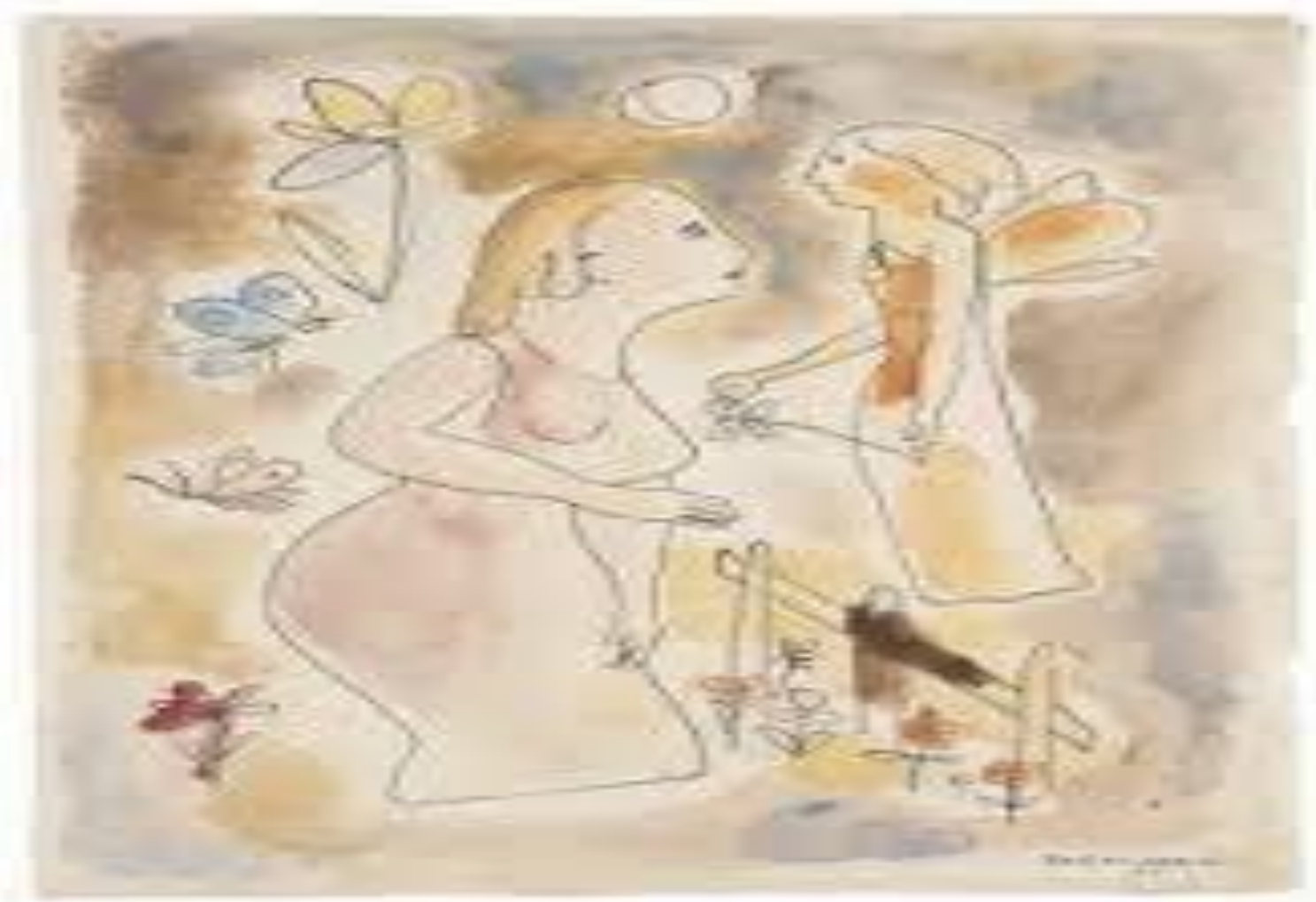

Figura 28. Ángeles (1941). Portocarrero 


\section{BIBLIOGRAFÍA}

\section{Obras de José Lezama Lima}

LEZAMA LIMA, José. "Paralelos. La pintura y la poesía en Cuba (en los siglos XVIII y XIX)". In: La visualidad infinita de José Lezama Lima. Introducción, estudio crítico, selección y notas de Leonel Capote. La Habana: 1994, p. 66-106.

. "Homenaje a René Portocarrero". In: La visualidad infinita. La Habana: Editorial Letras Cubanas, 1994a, p. 225-266.

Poesía completa. La Habana: Editorial Letras Cubanas, 1994b.

"Julián del Casal", "Las imágenes posibles", "Conocimiento de salvación", "Introducción al sistema poético", "Pascal y la poesía", "La dignidad de la poesía”. In: Obras Completas. Tomo II. Ensayos y cuentos. Madrid: Aguilar, 1977, p. 65-99; 152-182; 246-249; 393-427; 563-566; 760-792.

Paradiso. Editora da Universidade Federal do Rio de Janeiro (Colección

Archivos), 1996.

- "Dossier". In: Paradiso. Editora da Universidade Federal do Rio de Janeiro (Colección Archivos), 1996, p. 699-764.

. "Mitos y cansancio clásicos". In: La expresión americana. México: Fondo de Cultura Económica, 2001, p. 49-78.

. "Ver a Fayad Jamís". In: Tintas. México D.F.:1980, p. 7-10.

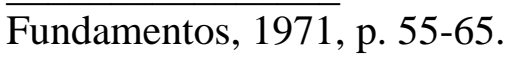

. "La imagen histórica". In: Las eras imaginarias. Madrid: Editorial . Las eras imaginarias. Madrid: Editorial Fundamentos, 1982.

Económica, 2001.

- La expresión americana. México D.F.: Fondo de Cultura

. Imagen y posibilidad. Selección, prólogo y notas de Ciro Bianchi Ross.

La Habana: Letras Cubanas, 1981.

Esferaimagen. Sierpe de don Luis de Góngora. Las imágenes posibles. Barcelona: Tusquets Editor, 1970.

. La visualidad infinita. Introducción, estudio crítico, selección y notas de Leonel Capote. La Habana: Editorial Letras Cubanas, 1994. 
La materia artizada (críticas de arte). Compilación y prólogo de

Roberto Prats Sariol. Madrid: Tecnos, 1996.

Oppiano Licario. México D.F.: Ediciones Era, 1997.

\section{Bibliografía}

ABEL, Elizabeth. "Redefining the Sister Arts: Baudelaire's response to the art of Delacroix". In: MITCHELL, W.J.T. The language of images. Chicago: The University of Chicago Press, 1980, p. 37-58.

ACHA, Juan; COLOMBRES, Adolfo; ESCOBAR, Ticio. Hacia una teoría americana del arte. Buenos Aires: Ediciones del Sol, 1991.

ACOSTA DE ARRIBA, Rafael. "Octavio Paz y la crítica de arte, un lugar de encuentro para el pensamiento". Revista Casa de las Américas, La Habana, No. 249, p. 22-31, octubrediciembre 2007.

ACOSTA, Luz Merino. "Orígenes: otra cara de la modernidad". In: Orígenes y la vanguardia cubana. México D.F.: Museo de Arte Moderno, 2000, p. 23-28.

ADORNO, Theodor. "El ensayo como forma". In: Notas de literatura. Barcelona: Ediciones Ariel, 1962, p. 11-36.

ARGAN, Giulio Carlo. Arte e crítica de arte. Lisboa: Editorial Estampa, 1993.

BARTHES, Roland. O prazer do texto. São Paulo: Editora Perspectiva, 2004. Crítica e verdade. São Paulo: Editora Perspectiva, 2009.

"De la obra al texto". Disponible en http://observatoriotrac.files.wordpress.com/2013/05/02-roland-barthes-de-la-obra-al-texto.pdf. Consultada en: 8 ago. 2013.

O óbvio e o obtuso. Ensaios críticos III. Rio de Janeiro: Nova Fronteira, 1990.

BAUDELAIRE, Charles. "Prefacio a Las flores del mal". In: Oeuvres completes. Paris: Gallimard, 1961.

"Le peintre de la vie moderne". In: Critique d'art suivi de critique musicale. Paris: Gallimard, 1992, p. 343-384.

. “A quoi bon la critique?" In: Critique d'art suivi de critique musicale.

Paris: Gallimard, 1992, p. 77-79.

. "Os dois crepúsculos". In: Paisagem moderna: Baudelaire e Ruskin.

Porto Alegre: Editora Sulina 2010, p. 45-50. 
. "Salon de 1859: le paysage". In: Critique d'art suivi de critique musicale. Paris: Gallimard, 1992, p. 320-328.

BAYÓN, Damián. Aventura plástica en Hispanoamérica. México D.F.: Fondo de Cultura Económica, 1991.

Qué es la crítica de arte. Buenos Aires: Editorial Columba, 1970.

BENJAMIN, Walter. "A obra de arte na era de sua reprodutibilidade técnica". In: Magia e técnica, arte e política. Ensaios sobre literatura e história da cultura. São Paulo: Editora Brasiliense, 1996, p. 165-196.

. "Sobre alguns temas em Baudelaire". In: Charles Baudelaire. Um lírico no auge do capitalismo. Obras Escolhidas. Volume III. São Paulo: Editora Brasiliense, 2000, p. 103-149.

BOLÍVAR, Natalia. "Raíces ancestrales de la pintura cubana". Revista La Jiribilla. Disponible en http://www.lajiribilla.cu/2007/n313_05/313_07.html. Consultada en: 25 nov. 2012.

BONNEFOY, Yves. Lugares y destinos de la imagen. Un curso de poética en el Collège de France. Buenos Aires: Ediciones El Cuenco de Plata, 2007.

BORGES, Jorge Luis. “El escritor argentino y la tradición”. In: Discusión. Madrid: Alianza, 1991, pp. 128-137.

Editores, 2005, p. 46-48.

"Kafka y sus precursores". In: Otras inquisiciones. Buenos Aires: Emecé

BOURDIEU, Pierre. As regras da arte. São Paulo: Companhia das Letras, 2002.

BÜRGER, Peter. Teoría de la vanguardia. Barcelona: Ediciones Península, 1987.

CALVO SERRALLER, Francisco. "Orígenes y desarrollo de un género: la crítica de arte". In: Historia de las ideas estéticas y de las teorías artísticas contemporáneas. Madrid: Editorial Visor, 2004, p. 155-171.

CAPOTE, Leonel. "José Lezama Lima y la pintura cubana". In: Lezama, Lima. José. La visualidad infinita. La Habana: Editorial Letras Cubanas, 1994, p. 17-66.

CASAL, Julián del. Obra poética. La Habana: Editorial Letras Cubanas, 1982.

CHIAMPI, Irlemar. "Lezama Lima: la imagen posible". Traducción Eduardo Milán. Revista de la Universidad de México, No. 13, (mayo 1982), p. 29-31.

- "La revista Orígenes ante la crisis de la modernidad en la América Latina”. In: revista Casa de las Américas, No. 232, julio-septiembre/2003, p. 127-135. 
CÓRTAZAR, Julio. “Dossier: Carta de Julio Cortázar a J. L. L.”. In: Paradiso. Madrid, París, México, Buenos Aires, San Pablo, Río de Janeiro, Lima: Colección Archivos, 1996, p. 717 720. - "Para llegar a Lezama Lima". In: Recopilación de textos sobre José Lezama Lima. Serie Valoración Múltiple. Madrid: 1970, Casa de las Américas, p. 146-168.

CRUZ-MALAVÉ, Arnaldo. El primitivo implorante: el sistema poético del mundo de José Lezama Lima. Amsterdam (Georgia): Ediciones Rodopi, 1994.

CLÜVER, Claus. "Ekphrasis Reconsidered. On Verbal Representations of Non- Verbal Texts". In: Lagerroth, Ulla-Britta, Hans Lund, Erik Hedling (eds.). Interart Poetics. Essays on the Interrelations of the Arts and Media. Amsterdam: Rodopi, 1997, p. 19-33.

DEBRAY, Régis. Vie et mort de l'image. Paris: Gallimard, 1992.

DERRIDA, Jacques. The truth in painting. Chicago: The University of Chicago Press, 1987.

De JUAN, Adelaida. Pintura cubana. Temas y variaciones. México D.F.: Universidad Nacional Autónoma de México, 1980.

DIDI-HUBERMAN, Georges. O que vemos, o que nos olha. São Paulo: Editora 34, 2005.

Les Éditions de Minuit, 1990. Devant l'image. Question posée aux fins d'une histoire de l'art. Paris:

ESPINOSA, Reynier. “José Lezama Lima ante la creación pictórica de su tiempo". Revista La Jiribilla. Disponible en: http://www.lajiribilla.cu/2010/n500_12/500_09.html. Consultada en: 2 mayo. 2012.

FRANCASTEL, Pierre. Imagem, visão e imaginação. Lisboa: Edições 70, 1987.

FRASCINA, Francis. "Realismo e ideologia: introdução à semiótica e ao cubismo". In: Primitivismo, cubismo, abstração. Começo do século XX. São Paulo: Cosac \& Naify Edições, 1998.

FRYE, Northrop. El camino crítico. Ensayo sobre el contexto social de la crítica literaria. Madrid: Taurus Ediciones, 1986.

GIORDANO, Alberto. Modos del ensayo. De Borges a Piglia. Rosario: Beatriz Viterbo, 2005.

GONÇALVES, José Aguinaldo. Relações homológicas entre texto e imagem. São Paulo: EDUSP, 1994.

GONZÁLEZ CRUZ, Iván. Diccionario vida y obra de José Lezama Lima. Valencia: Generalitat Valenciana, 2000. 
GONZÁLEZ ECHEVARRÍA, Roberto. "La fiesta en Lezama”. Revista Letras Libres. Disponible en: http://www.letraslibres.com/revista/libros/la-fiesta-en-lezama. Consultada en: 25 nov. 2012.

GRÜNER, E. “El ensayo, un género culpable”. Revista Sitio, Buenos Aires, No. 4/5, p. 51-55, año 1985.

HARRISON, Charles. "O primitivismo e o moderno". In: Primitivismo, cubismo, abstração. Começo do século XX. São Paulo: Cosac \& Naify 1998, p. 3-47.

HELGUERA, Pablo. "Las guerras de la contemplación. Los caminos de la crítica poética en Latinoamérica". Disponible en: http://universes-in-universe.de/columna/col49/col49.htm. Consultada en: 8 ago. 2012.

HUERTA, David. "La poesía de las imágenes". Revista de la Universidad de México. México D.F.: No. 46, p. 103-105, dic.2007.

HUYSSEN, Andreas. Después de la gran división. Modernismo, cultura de masas, posmodernismo. Córdoba: Adriana Hidalgo Editora, 2002.

Interrogando a Lezama Lima. Casa de las Américas-Centro de Investigaciones literarias. Barcelona: Editorial Anagrama, 1971.

JHONSON, Lee McKay. The metaphor of painting. Essays on Baudelaire, Ruskin, Proust and Pater. Ann Arbor: University of Michigan, 1980.

JUSTINO, Maria José. "Criticar...é entrar na crise. Uma perspectiva histórica da crítica de arte”. In: Os lugares da crítica de arte. São Paulo: Imprensa Oficial, 2005, p. 13-34.

KANDINSKY, Wassily, Do Espiritual na Arte, «Arte e Sociedade 8», $5^{\circ}$ edição, Lisboa, Publicações D. Quixote, 1912, 1 vol., p. 21-130.

KANZEPOLSKY, Adriana. Un dibujo del mundo: extranjeros en Orígenes. Rosario: Beatriz Viterbo Editora, 2004.

KERN, Daniela (comp). "Introdução". In: Paisagem moderna. Baudelaire e Ruskin. Porto Alegre: Editora Sulina 2010, p. 7-26.

KLEE, Paul. Sobre arte moderna e outros ensaios. Rio de Janeiro: Jorge Zahar Editor, 2001. Traducción de Pedro Süssekind.

KRIEGER, Murray. Ekphrasis: The Illusion of the Natural Sign. Baltimore \& London: Johns Hopkins University Press, 1992.

. "The problem of Ekphrasis: Image and Words, Space and Time and The Literary Work". In: Pictures into words. Theoretical and Descriptive Approaches to Ekphrasis. Valerie Robillard y Els Jongeneel (eds.). Amsterdam: VU University Press, 1998. 
LESSING, Gotthold Ephraim. Laocoonte ou sobre as fronteiras da pintura e da poesía.. Traducción Márcio Seligmann-Silva. São Paulo: Iluminuras, 1998.

LUKÁCS, Georg. "Sobre la esencia y forma del ensayo" (Carta a Leo Popper). In: El alma y las formas. Barcelona: Grijalbo, 1970, p. 15-39.

LITVAK, Lily. "Rubén Darío y la obra de arte". Disponible en: www.amadonervo.net/transmigraciones/pdf/dario.pdf. Consultada en: 10 ago. 2012.

LOZANO-RENIEBLAS, Isabel. "La ecfrasis de los ejércitos o los límites de la enárgeia". In: Monteagudo, 3(10), p. 29-38.

MAÑACH, Jorge. "Indagación del choteo". Calibán. Revista Cubana de Pensamiento e Historia.

Disponible

en http://www.revistacaliban.cu/articulos/9_indagacion_choteo.pdf?numero=9. Consultada en: 10 ago. 2012.

MARTÍ, José. Nuestra América. Caracas: Biblioteca Ayacucho, 1985.

"Nueva exhibición de los pintores impresionistas" y "La exhibición de pinturas del ruso Vereschagin”. In: Obras escogidas en tres tomos. La Habana: Editorial de Ciencias Sociales, 1992, p. 23-27, 254-262.

MATEO PALMER, Margarita. "Las palabras como peces dentro de la cascada: Lezama Lima y el lenguaje". Revista Casa de las Américas, La Habana, No. 244, p. 21-29, julio-septiembre 2006.

MÉNDEZ, Roberto. "La sonrisa acumulativa e indescifrable del cubano. José Lezama Lima y las artes plásticas". Academia Cubana de la Lengua. Disponible en: http://www.acul.ohc.cu/sonrisa_acumulativa.pdf. Consultada en: 5 nov. 2012.

"Collazo, el pintor de la siesta". Disponible en: http://www.habanaradio.cu/singlefile/?secc=13\&subsecc=117\&id_art=20091106170202. Consultada en: 9 de nov. 2012.

MONTERO, Óscar. "Las ordalias del sujeto: "Mi museo ideal” y "Marfiles viejos" de Julián del Casal". Disponible en: http://revistaiberoamericana.pitt.edu/ojs/index.php/Iberoamericana/article/viewFile/4559/4726. Consultada en: 15 ene. 2014.

OLMOS, Ana Cecilia. Políticas do primitivo: as estéticas modernistas de Mário de Andrade e Lezama Lima.1994. Disertación. (Maestría en Teoría Literaria) - Departamento de Literatura, Universidad Federal de Santa Catarina, Florianópolis, 1994.

ORTEGA Y GASSET, José. La deshumanización del arte y otros ensayos estéticos. Madrid: Revista de Occidente. Colección El Arquero, 1964.

Orígenes y la vanguardia cubana. México D.F.: Museo de Arte Moderno, 2000. 
OVIEDO, José Miguel. Breve historia del ensayo hispanoamericano. Madrid: Alianza Editorial, 1991.

Paz, Octavio. Corriente alterna. México D.F: Siglo XXI Editores, 1984.

Los privilegios de la vista I. Arte moderno universal. México D.F: Fondo de Cultura Económica, 1994. 1991, p. 7-44.

. "El caracol y la sirena (Rubén Darío)". In: Cuadrivio. Barcelona: Seix Barral, . "La semilla". In: Corriente alterna. México D.F.: Siglo XXI Editores, 1984a, p. 24-28.

PELLÓN, Gustavo. La visión jubilosa de José Lezama Lima. Un estudio sobre Paradiso y otras obras en prosa. Caracas: Monte Ávila Editores, 2005.

PERRONE-MOISÉS, Leyla. Altas literaturas. São Paulo: Companhia das Letras, 2003.

PIMENTEL, Luz Aurora. El espacio en la ficción. Ficciones espaciales. México D.F.: UNAM, Siglo XXI Editores, 2001.

http://www.lpimentel.filos.unam.mx/sites/default/files/poligrafias/4/13-luz-aurorapimentel.pdf. Consultada en: 24 oct. 2013

PINO SANTOS, Carina. "El camino de la abstracción". Revista La Jiribilla. Disponible en http://www.lajiribilla.co.cu/2011/n506_01/506_09.html. Consultada en: 15 ene. 2013.

POE, Edgar Allan. "La filosofía de la composición". Disponible en http://www.catedras.fsoc.uba.ar/reale/filosofia-de-la-composicion-poe.pdf. Consultada en: 25 abr. 2013.

RAYMOND, Marcel. De Baudelaire al surrealismo. México D.F.: Fondo de Cultura Económica, 1960.

REGEL, Günther. "Prefácio". In: KLEE, Paul. Sobre arte moderna e outros ensaios. Rio de Janeiro: Jorge Zahar Editor, 2001, p. 11-36. Traducción de Pedro Süssekind.

RICOEUR, Paul. La metáfora viva. Madrid: Ediciones Europa, 1980.

ROGERS, Franklin R. Painting and Poetry: Form, Metaphor, and the Language of Literature. Lewisburg: Bucknell University Press, 1985.

SANCHÉZ-RAMÓN, Mar. "Escritura e imagen en Yves Bonnefoy". In: Escritura e imagen, No. I, 2005, p. 41-58. 
SANTÍ, Enrico Mario. "Lezama, Vitier y la crítica de la razón reminiscente”. Revista Iberoamericana 41, No. 92-93, p. 535-546.

SARDUY, Severo. "Dispersión. Falsas notas / Homenaje a Lezama". In: Escrito sobre un cuerpo. Ensayos sobre crítica. Buenos Aires: Editorial Sudamericana, 1969, p. 61-89.

. "Un heredero". In: Paradiso. Madrid; París, México, Buenos Aires, San Pablo, Río de Janeiro, Lima: Colección Archivos, 1996, p. 590-597.

. "El barroco y el neobarroco". In: América Latina en su literatura. México D.F.: Unesco, 1972, p. 167-184.

SOLANA, Guillermo. "Crítica y modernidad". In: Historia de las ideas estéticas y de las teorías artísticas contemporáneas. Madrid: Editorial Visor, 2004, p. 333-345.

TAYLOR, Joshua C. "Two visual excursions". In: The language of images. Chicago: University of Chicago Press, 1980, p. 25-36.

TODOROV, Tzvetan. "Conocimiento y compromiso (Northrop Frye)". In: Crítica de la crítica. Barcelona: Paidós, 1991, p. 87-101.

VENTURI, Lionello. História da crítica de arte. Lisboa: Edições 70, 2007.

WEINBERG, Liliana. "El ensayo y la poética del pensar". In: Antología de textos literarios en inglés. Emilia Rébora Togno (Coord). México D.F.: Facultad de Filosofía y Letras, UNAM, 2007.

WELLEK, René. "The poet as Critic, the Critic as Poet, the Poet-Critic". In: Discriminations: further concepts of criticism. New Haven: Yale University Press, 1970, p. 253-272.

WHITE, Hayden. Trópicos do discurso. Ensaios sobre a crítica da cultura. São Paulo: Editora da Universidade de São Paulo (EDUSP), 2001.

WOOD, Yolanda. "Arte del caribe, el decenio que terminó el siglo XX". Revistas Excelencias. Disponible en: http://www.revistasexcelencias.com/arte-porexcelencias/editorial-1/reportaje/arte-del-caribe-el-decenio-que-termino-el-soglo-Xx.

Consultada en: 1 ago. 2012. 